\title{
DISPONIBILIDADE DE MICRONUTRIENTES EM SOLOS DA AMAZONNIA
}

MARIA DO ROSARIO LOBATO RODRIGUES

Tese apresentada à Escola Superior de Agricultura "Luiz de Queiroz", Universidade de São Paulo, para obtenção do título de Doutor em Agronomia, Área de Concentração: Solos e Nutrição de Plantas.

PIRACICABA

Estado de São Paulo - Brasil

Março - 1998 


\section{DISPONIBILIDADE DE MICRONUTRIENTES EM SOLOS DA AMAZÔNIA}

\section{MARIA DO ROSÁRIO LOBATO RODRIGUES}

Engenheiro Agrônomo

Orientador: Prof. Dr. EURÍPEDES MALAVOLTA

Tese apresentada à Escola Superior de Agricultura "Luiz de Queiroz", Universidade de São Paulo, para obtenção do título de Doutor em Agronomia, Área de Concentração: Solos e Nutrição de Plantas.

PIRACICABA

Estado de São Paulo - Brasil

Março - 1998 


\title{
DISPONIBILIDADE DE MICRONUTRIENTES EM SOLOS DA AMAZÔNIA
}

\author{
MARIA DO ROSÁRIO LOBATO RODRIGUES
}

Aprovada em

Comissão Julgadora:

Prof. Dr. Eurípedes Malavolta

Prof. Dr.

Prof. Dr.

Prof. Dr.

Prof. Dr.
CENA/USP

ESALQ/USP

ESALQ/USP

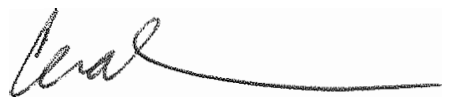

Prof. Dr. Eurípedes Malavolta Orientador 
Dados Internacionais de Catalogação na Publicação (CIP) DIVISÃO DE BIBLIOTECA E DOCUMENTAÇÃO - Campus "Luiz de Queiroz"/USP

Rodrigues, Maria do Rosário Lobato

Disponibilidade de micronutrientes em solos da Amazônia / Maria do Rosário Lobato Rodrigues. - - Piracicaba, 1998.

$156 \mathrm{p}$.

Tese (doutorado) - Escola Superior de Agricultura Luiz de Queiroz, 1998. Bibliografia.

1. Amazônia 2. Fertilidade do solo 3. Micronutriente 4. Solo I. Título

$\operatorname{CDD} 631.42$ 
Ao Ayres, Thiago, Caroline e Matheus e a

família Lobato Rodrigues Almeida Nascimento

OFEREÇO

Ao Prof. Dr. Eurípedes Malavolta,

na condição de sua $85^{\mathrm{a}}$ orientada

DEDICO 


\section{AGRADECIMENTOS}

Ao Prof. Dr. Eurípedes Malavolta, por ter me concedido o privilégio de sua segura orientação, pelo estímulo, apoio e exemplo de profissional;

À Embrapa/Centro de Pesquisa Agroflorestal da Amazônia Ocidental (CPAA);

À Escola Superior de Agricultura "Luiz de Queiroz" (ESALQ/USP) e ao seu corpo docente;

Ao $\mathrm{CNPq}$, pela concessão da bolsa de estudo;

À Técnica de Laboratório, Cleusa Cabral, pelo apoio logístico durante as análises e, acima de tudo, pela amizade;

À Prof. Janice Carvalho (UFLA/Lavras) e ao Prof. Takashi Muraoka (CENA/USP), pelo apoio e amizade;

À Prof. Sônia Piedade pela ajuda na definição do delineamento experimental e ao Prof. Marcelo Alves, na utilização do software SANEST;

Ao Prof. Pimentel Gomes, pelos esclarecimentos na interpretação estatística dos dados;

À todos os colegas do CPAA, em especial ao Newton Bueno, Wenceslau, Raimundo Nonato e Larissa, pelo auxílio na realização deste trabalho e pela amizade;

À seção de Química Analítica do CENA, em especial à Prof. Maria Fernanda G. G. Rosias e à Técnica de Laboratório Aparecida de Fátima Patreze, pela utilização do plasma;

Aos Técnicos de Laboratório: Roberto, Henrriqueta, Marileusa e Sandra.

Aos amigos que encontrei: Rosana Vieira, Ivanildo, Francisco Espírito Santo, Susineide, João, Oscar, Ronaldo, Pedro e Carmen Neves, Fernando e Ceiça Cintra, Amoacir e Virgínia Fabrício e em especial ao Adônis Moreira, Maria da Conceição Carvalho, Fernando e Silvia Amaral, por terem tornado mais agradável a minha estada em Piracicaba. 


\section{SUMÁRIO}

Página

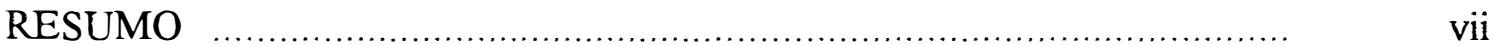

SUMMARY

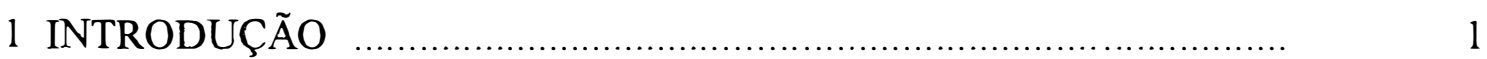

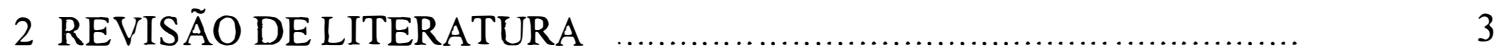

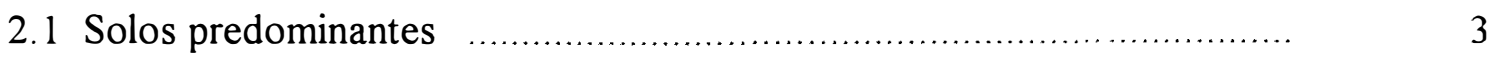

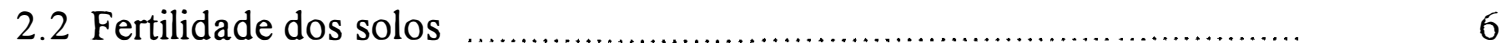

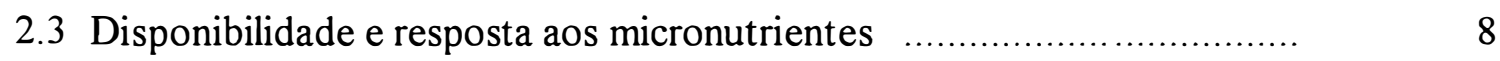

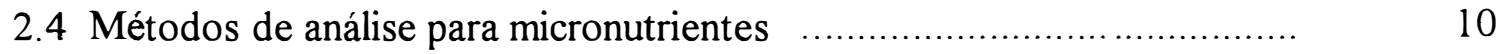

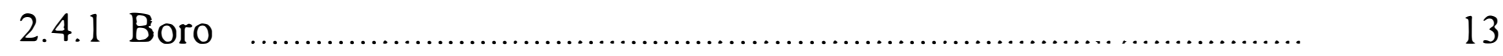

2.4.2 Cobre, ferro, manganês e zinco ….................................................

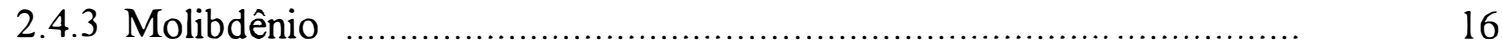

3 MATERIAL E MÉTODOS ….........................................................

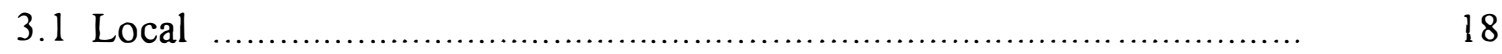

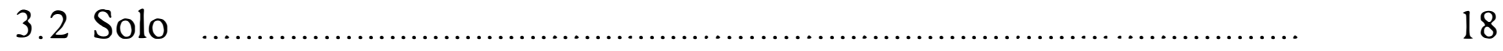

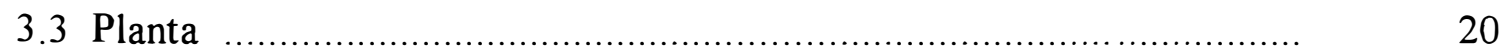

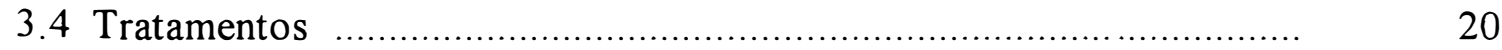

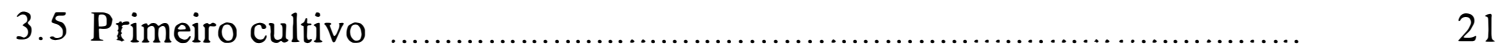

3.5.1 Fornecimento de nutrientes e incubação das amostras de solo …....... 21

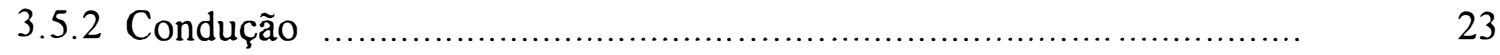

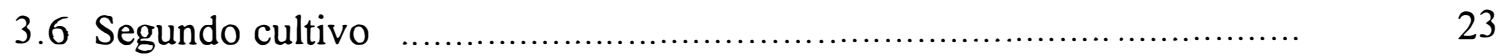


3.7 Terceiro cultivo

3.8 Métodos químicos de análise das amostras de solo

3.9 Análise química do material vegetal f............................................... 26

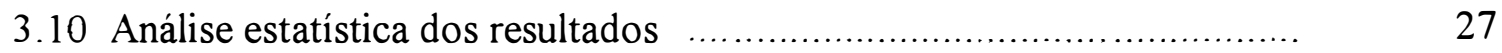

4 RESULTADOS E DISCUSSÃO …................................................ 28

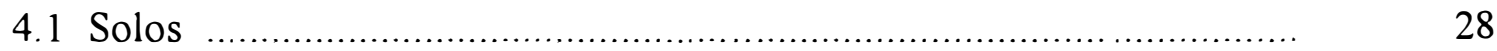

4.2 Desenvolvimento das plantas e produção de matéria seca vegetal .... 32

4.3 Análise química do material vegetal …........................................ 34

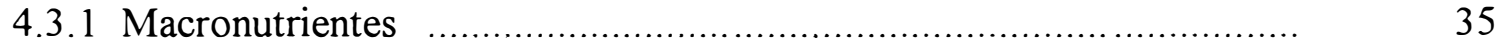

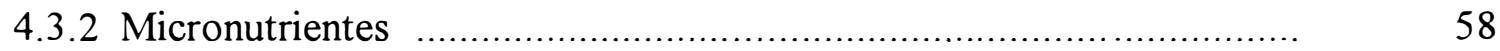

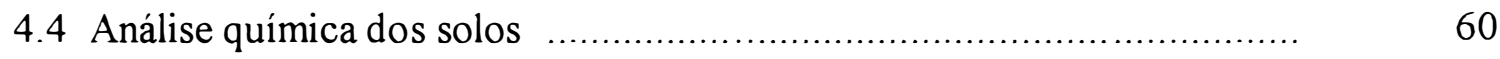

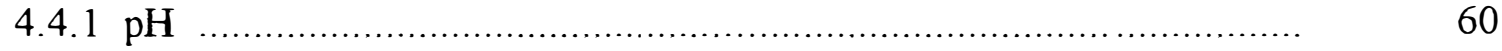

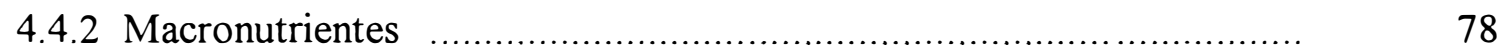

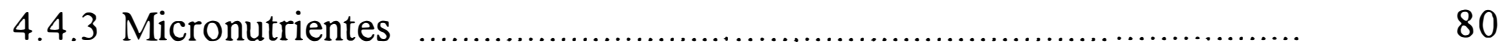

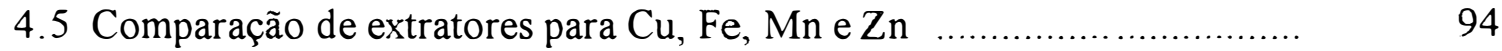

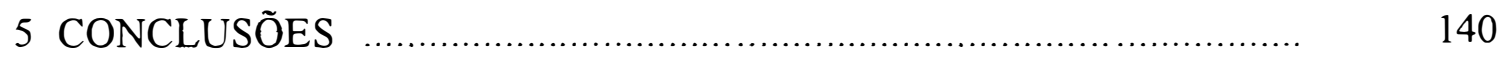

REFERÊNCIAS BIBLIOGRÁFICAS …............................................ 141 


\title{
DISPONIBILIDADE DE MICRONUTRIENTES \\ EM SOLOS DA AMAZÔNIA
}

\author{
Autora: MARIA DO ROSÁRIO LOBATO RODRIGUES \\ Orientador: Prof. Dr. EURÍPEDES MALAVOLTA
}

\section{RESUMO}

Avaliou-se a disponibilidade de micronutrientes em solos da Região Amazônica por métodos químicos e em três cultivos sucessivos de arroz (IAC-165). Foram usados dois latossolos amarelos álicos (LAa), um latossolo amarelo distrófico (LAd), um latossolo húmico antropogênico $(\mathrm{LH})$, dois podzóis $(\mathrm{P})$, dois podzólicos amarelos álicos (PAa), um podzólico vermelho-amarelo (PV) e um solo aluvial (AL). Utilizou-se a técnica de diagnóstico por subtração. O tratamento completo continha todos os macros e micronutrientes. Incluiu-se também uma testemunha absoluta (sem adição de calcário e fertilizantes). O calcário e micronutrientes foram adicionados antes do primeiro cultivo que foi colhido com 58 dias de idade. O segundo e terceiro cultivos foram colhidos aos 68 e 70 dias após a germinação, respectivamente. Os nutrientes disponíveis nas diferentes soluções extratoras foram determinados após a incubação, antes do primeiro plantio e após cada cultivo.

Foram encontradas grandes variações nas características do solo que podem influenciar a disponibilidade de micronutrientes: matéria orgânica (19 a $\left.44 \mathrm{~g} \mathrm{dm}^{-3}\right), \mathrm{pH}$ $\left(2,7\right.$ a 4,5), capacidade de troca de cátions (43 a $196 \mathrm{mmol}_{\mathrm{c}} \mathrm{dm}^{-3}$ ) e teor de argila (62 a $\left.865 \mathrm{~g} \mathrm{~kg}^{-1}\right)$. Na fração argila predominou a caulinita, entretanto o solo $\mathrm{AL}$ apresentou também mica e montmorilonita. Alta acidez e baixa fertilidade resultaram em produção de matéria seca significativamente menores na testemunha absoluta. De modo geral, a produção de matéria seca decresceu do primeiro para o terceiro cultivo. 
Houve efeito dos tratamentos na concentração e conteúdo de micronutrientes na matéria seca da parte aérea, sendo menor no AL e no LH. Em todos os solos as maiores respostas foram devidas ao $\mathrm{Zn}$ e Mo. A concentração de Mo foi drasticamente reduzida do primeiro para o terceiro cultivo. A análise de solo mostrou que $\mathrm{P}, \mathrm{K}$ e $\mathrm{Ca}$ foram os principais fatores limitantes. Resposta significativas observadas principalmente para $\mathrm{Cu}$, Zn e Mo aumentaram no terceiro cultivo. O extrator Mehlich 1, de modo geral, mostrou os melhores coeficientes de correlação entre os elementos no solo e na planta. 


\title{
AVAILABILITY OF MICRONUTRIENTS IN SOILS OF THE AMAZONAS REGION
}

\author{
Author: MARIA DO ROSÁRIO LOBATO RODRIGUES \\ Adviser: Dr. EURÍPEDES MALAVOLTA
}

\section{SUMMARY}

The availability of micronutrients in soils of the Amazonas region was evaluated both by chemical methods and by growing three successive crops of rice (IAC165). Two Yellow alic latosols (LAa), one Yellow dystrophic latosol (Lad), one Humic anthropogenic latosol (LH), two Podzols (P), two Yellow alic podzols (PAa), one Red Yellow podzolic (PV) and one alluvial soil (AL) were used. The diagnosis by subtraction technique was used. The complete treatment received all macro and micronutrients. An absolute control (no amendment, no fertilizer added) was also included. Lime and micronutrients were added before the first planting which was harvested at 58 days of age. The second and third crop were harvested respectively 68 days and 70 days after germination. Available nutrients in different extracting solutions were determined after incubation, before first planting, and after each harvest.

Large variations in soil characteristics which might influence the availability of micronutrients were found: organic matter $\left(19\right.$ to $\left.44 \mathrm{~g} \mathrm{dm}^{-3}\right), \mathrm{pH}(2,7$ - 4,5), CEC (43 $196 \mathrm{mmol}_{\mathrm{c}} \mathrm{dm}^{-3}$ ), clay (62 to $865 \mathrm{~g} \mathrm{~kg}^{-1}$ ). Kaolinite prevails in the clay fraction. AL, however has also mica and montmorillonite. High acidity and low fertility resulted in dry matter yields significantly lower in the absolute control. As a rule dry matter decreased from the first to the third crop.

There were effect of treatments both in concentration and content of micronutrients in the tissue, being lower in $\mathrm{AL}$ and $\mathrm{LH}$. In all soils larger responses were due to $\mathrm{Zn}$ and Mo. Mo concentration was drastically reduced from the first to the third cropping. Soil analyses disclosed that $\mathrm{P}, \mathrm{K}$ and $\mathrm{Ca}$ are the chief limiting factors. 
Significant responses observed mainly to $\mathrm{Cu}, \mathrm{Zn}$ and $\mathrm{Mo}$ increased in the third harvest. Mehlich 1, as a rule, gave the highest correlation coefficients between soil and plant elements. 


\section{INTRODUÇÃO}

A região Amazônica abrange cerca de cinco milhões de $\mathrm{km}^{2}$, que corresponde a aproximadamente $59 \%$ do território brasileiro. A região Norte, formada pelos estados do Amazonas, Acre, Pará, Roraima, Amapá e Tocantins, ocupa uma área de aproximadamente três milhões e meio de $\mathrm{km}^{2}$, o que corresponde a $74 \%$ da Amazônia Legal ou $42 \%$ do Brasil. É caracterizada de um lado por uma imensa gama de variações climáticas, geológicas e edáficas e, de outro, por uma exuberância diversificada de flora e fauna.

A maioria dos solos da Amazônia são derivados de rochas sedimentares e ígneas ácidas e apresentam uma fertilidade natural muito baixa; possuem, porém, topografia favorável, são profundos, permeáveis, bem drenados, podendo apresentar uma elevada produtividade potencial sob um bom manejo, o que requer o uso de quantidade substancial de fertilizantes. As condições adversas da região contribuem para que as pesquisas sejam feitas com grande lentidão; poucas são as informações sobre a disponibilidade dos nutrientes nestes solos e os trabalhos com micronutrientes são praticamente inexistentes. Um outro aspecto a considerar é que a agricultura itinerante, sistema mais usado na região, normalmente recicla quantidades adequadas de micronutrientes para suprir as culturas de subsistência; entretanto, a produtividade obtida devido aos efeitos fertilizantes e corretivos das cinzas, diminuem progressivamente após o primeiro cultivo.

A exemplo do que já vem ocorrendo em outras regiões tropicais, a intensificação da produção agrícola na Amazônia poderá levar a um desequilíbrio em relação aos micronutrientes, notadamente nos solos dos ecossistema de terra firme, onde 
predominam solos de baixa fertilidade natural. Assim, o crescente uso de fertilizantes nitrogenados, fosfatados e potássicos em variedades de alto rendimento, visando o aumento da produtividade, principalmente dos cultivos para exportação comercial, poderá trazer como consequência desequilibrios nutricionais, onde a disponibilidade de outros nutrientes exigidos em menor quantidade pela planta, como é o caso dos micronutrientes poderá tornar-se fator limitante da produção.

Essa situação evidencia a necessidade de diagnosticar o nível de disponibilidade desses elementos no solo, com o propósito de estabelecer se seus teores vão ou não constituir fatores limitantes à produtividade das culturas, pois somente com a avaliação da fertilidade atual e/ou potencial desses solos será possível identificar áreas deficientes e aprimorar as recomendações de adubação, evitando-se possíveis prejuízos nas produções agrícolas e atingindo níveis satisfatórios de produtividade. $\mathrm{O}$ uso da análise de solo e de tecido vegetal, diagnose visual e outras técnicas é de primordial importância na obtenção de informações básicas que auxiliem no processo da diagnose correta de possíveis problemas com os micronutrientes. A análise química, uma das mais difundidas técnicas de avaliação da fertilidade do solo, representa fonte valiosa de informação dessa disponibilidade, quando interpretada corretamente. As informações assim obtidas relativas ao solo são, depois, avaliadas por meio de experimentos em vasos e no campo, verificando-se a resposta das plantas, bem como, ajudando na seleção de um método viável de avaliação da disponibilidade do nutriente no solo.

Com base nesse pressuposto, este estudo foi realizado, visando contribuir para a obtenção de informações sobre a disponibilidade dos micronutrientes boro, cobre, ferro, manganês, molibdênio e zinco nos principais tipos de solos da Amazônia, usando arroz como planta-teste, através de cultivos sucessivos em vasos, em condições de casa de vegetação. 


\section{REVISÃO DE LITERATURA}

\subsection{Solos predominantes}

A região Amazônica é formada, em nível generalizado, por duas unidades geomorfológicas, sendo uma delas representada por um relevo que varia de suavemente ondulado a ondulado, apresentando-se em chapadas e áreas dissecadas, constituindo pequenas colinas com vales estreitos. Formam a "terra firme", na denominação regional, e ocupam cerca de $80 \%$ da Amazônia. Nesta unidade são encontrados Latossolos, Podzólicos, Podzóis, Regossóis e Areias Quartzosas. A outra unidade é representada pela planície de aluvião que se encontra às margens dos cursos de água e constituem as várzeas. Nesta unidade encontram-se solos Aluviais e Gleis.

Uma distribuição geral dos principais tipos de solos na região Amazônica apresentada por Nicholaides et al. (1983) mostra que cerca de $75 \%$ desses solos pertencem à ordem dos oxissolos (46\%) e dos ultissolos (29\%), o que corresponde a uma extensão de aproximadamente 362 milhões de hecteres. Nos restantes $25 \%$ estão incluídos os solos extremamente arenosos e quimicamente pobres, onde a vegetação natural é do tipo savana (3,3\%); as áreas com problemas de drenagem $(13,6 \%)$; e os solos moderadamente férteis e bem drenados $(8,4 \%)$, que correspondem a uma extensão de cerca de 40 milhões de hectares.

Dentre as unidades taxonômicas predominantes nos ecossistemas de terra firme, merecem destaques os Latossolos, seguidos dos Podzólicos, como solos de maior importância para a região, por estarem localizados nas áreas de maior pressão de ocupação da terra e onde a agricultura é desenvolvida de forma mais intensiva. 
Os Latossolos que ocupam $35 \%$ da área total da região, são representados pelos latossolo amarelo (LA), latossolo vermelho-amarelo (LV), latossolo vermelho-escuro (LE) e latossolo roxo (LR), com predominância do primeiro. Apresentam perfil profundo e bem desenvolvido, com presença de horizonte $\mathrm{B}$ latossólico, sendo que a sequência de horizontes $\mathrm{A}, \mathrm{B}$ e C apresenta modesta diferenciação de horizontes. Neles, o teor de argila pode variar de $15 \%$ a mais de $60 \%$, sendo que, de maneira geral, predomina a textura argilosa a muito argilosa. São solos em avançado estágio de intemperização, onde a fração areia é constituída praticamente por minerais resistentes ao intemperismo. $\mathrm{Na}$ fração argila há predomínio da caulinita, podendo ocorrer ainda gibbsita, goethita e hematita. Sombroek (1966) relata que mais de $80 \%$ dos minerais cristalinos distribuídos na fração argila dos LA da região Amazônica é caulinita. Estudando a mineralogia da argila de solos típicos da região, Kitakawa \& Möller (1979) também verificaram que a caulinita foi o mineral que predominou na fração argila dos solos com horizonte B óxico; goethita foi detectada e hematita foi encontrada exceto num perfil de LV, enquanto que a gibbsita estava sempre presente. Segundo Vieira \& Santos (1987), também podem ocorrer nestes solos pequenas quantidades de minerais de argila $2: 1$, tais como montmorilonita, vermiculita e mica. As diferenças básicas entre os latossolos referem-se à cor e ao teor de ferro total. As matizes no horizonte óxico para o LA estão em torno de $10 \mathrm{YR}$ com teor de ferro inferior a $5 \%$, para o LV entre $5 \mathrm{YR}$ e $7,5 \mathrm{YR}$ com o teor de ferro em torno de $10 \%$ e para o LE entre 2,5YR a 5YR com teor de ferro total entre 10 e 18\% (Demattê, 1988).

$\mathrm{Na}$ classe dos solos Podzólicos, que ocupam $45 \%$ da área total da região, predominam o podzólico amarelo (PA) e o podzólico vermelho-amarelo (PV) que apresentam perfil bem desenvolvido, com sequência de horizontes A, B e C. São solos minerais profundos e mediamente profundos e que apresentam horizonte $\mathrm{B}$ textural. Salienta-se ainda que de uma maneira geral, as áreas de PV de drenagem moderada tem dado origem aos PV plínticos (Demattê, 1988). Os solos podzólicos apresentam cores variáveis, porém os horizontes $\mathrm{B}$ de maneira geral apresentam matizes entre $5 \mathrm{YR}$ e 7,5YR. Os horizontes superficiais podem ser escuros devido a ação da matéria orgânica 
ou esbranquiçados, no caso dos horizontes álbicos. A textura varia normalmente de média a muito argilosa, e a distribuição de argila em profundidade aumenta acentuadamente do horizonte $\mathrm{A}$ para o $\mathrm{B}$, tornando a drenagem mais restrita na subsuperfície. O horizonte B textural apresenta estrutura fraca a moderada. Devido a tais características físicas, aliadas ao relevo um pouco mais acidentado, os riscos de erosão nestes solos são muito grandes, bem superiores aos dos latossolos (Vieira \& Santos, 1987; Demattê, 1988). A fração areia é dominada por quartzo, com pequena quantidade de minerais intemperizáveis. Na fração argila, Kitakawa \& Möller (1977, 1979) encontraram dominância da caulinita, sesquióxidos de $\mathrm{Fe}$ (hematita e goethita) e pequenas quantidades de mica e vermiculita dioctraedral.

Os Podzóis apresentam perfil profundo, sendo caracterizados pelo horizonte B podzol, sobre o qual se assenta, em geral, um horizonte E extremamente lavado (álbico); apresentam eluviação de húmus e óxidos de $\mathrm{Fe}$ e $\mathrm{Al}$ para o horizonte $\mathrm{B}$. Estão concentrados nos Estados do Amazonas e de Roraima e ao longo das restingas, normalmente associados a areias quartzosas. Segundo Sioli (1975), a presença de solos arenosos, praticamente sem material mais fino (silte e argila), muito pobres e com lençol freático elevado, está relacionada com águas escuras e $\mathrm{pH}$ muito baixo, como é típico do Rio Negro.

As Areias Quartzosas, formadas a partir de sedimentos arenosos dominantes do Quaternário, são encontradas em relevo plano, sob vegetação de floresta densa a campinarana. Apresentam perfil pouco desenvolvido, com sequência de horizonte $\mathrm{A}$ e $\mathrm{C}$, e às vezes podem apresentar um horizonte $\mathrm{B}$ incipiente, tendendo para B textural ou um B latossólico (Vieira \& Santos, 1987).

Os Aluviais são solos minerais poucos desenvolvidos, não hidromórficos, originados de sedimentos aluviais recentes, constituídos por camadas estratificadas sem relação pedogenética entre si e que não apresentam horizonte glei dentro de $60 \mathrm{~cm}$ da superficie. Apresentam características fisicas, químicas e morfológicas muito variadas a curta distância, tanto na horizontal quanto na vertical, em função dos tipos de sedimentos transportados. São encontrados não somente margeando rios e lagos, em 
várzeas ou terraços formados por sedimentos recentes que na Amazônia, vêm sofrendo inundações periódicas, por vezes constituindo a calha de drenagem em áreas de topografia movimentada (Vieira, 1988). Podem ser distróficos, álicos e eutróficos; ser mais grosseiro no curso superior dos rios e ter mais minerais primários do que aqueles formados no curso inferior. Normalmente apresentam grande potencialidade agrícola.

\subsection{Fertilidade dos solos}

Os solos da região Amazônica se desenvolvem sob condições drásticas de elevadas temperaturas e precipitação que favorecem a velocidade das reações químicas, físico-químicas e biológicas. A maioria dos solos dessa região é quimicamente pobre, sendo a composição mineralógica dominada por óxidos de ferro e alumínio e caulinita (Kitakawa \& Möller, 1979). Os nutrientes perdidos não podem ser repostos pelo substrato geológico pobre e, nem mesmo, pelos aportes propiciados pela decomposição da matéria orgânica (Jordan, 1985 e 1987). Consequentemente, cerca de $80 \%$ dos solos mostram baixa capacidade de troca de cátions (Malavolta, 1987). Em contraste, praticamente não há limitações de natureza fisica à exploração agrícola dos solos da Amazônia. Apenas $6 \%$ da região apresenta declividade superior a 30\%. São solos profundos e bem drenados na maioria das vezes, devido à ação cimentante da matéria orgânica sobre os óxidos de ferro e alumínio, bem como dos óxidos de ferro nas argilas, responsáveis pela grande estabilidade dos agregados destes solos, diminuindo consequentemente os riscos de erosão e compactação (Sanchez, 1976; Demattê, 1988).

Pelo exposto, conclui-se que a maior limitação imposta pelos solos da Amazônia ao desenvolvimento da agricultura é mais de natureza química do que fisica. Um dos elementos mais problemáticos é o fósforo, não só pelas baixas concentrações, mas principalmente devido à baixa disponibilidade causada pela adsorção por óxidos, hidróxidos e caulinitas. A toxicidez de alumínio, a principal causa do reduzido crescimento das plantas nos solos ácidos, tem influência sobre três quartos da região. Baixas reservas de cálcio e potássio são também comuns (Sanchez et al., 1982). Segundo Jordan (1985) a decomposição rápida e contínua da matéria orgânica causa a 
geração de $\mathrm{H}^{+}, \mathrm{HCO}_{3}{ }^{-}$e $\mathrm{NO}_{3}{ }^{-}$, garantida pelas altas temperaturas e umidades da região. Íons tais como hidrogênio e bicarbonato substituem os elementos nutritivos nas superficies coloidais, que podem ser perdidos por lixiviação. Como consequência, 15\% dos solos da Amazônia apresentam valores de capacidade de troca de cátions (CTC) abaixo de $4 \mathrm{cmol}_{\mathrm{c}} \mathrm{kg}^{-1}$. Segundo Demattê (1988), a participação das bases é muito pequena, em geral abaixo de $0,3 \mathrm{cmol}_{\mathrm{c}} \mathrm{kg}^{-1}$ nos oxissolos e de $0,5 \mathrm{cmol}_{\mathrm{c}} \mathrm{kg}^{-1}$ nos ultissolos. O teor de alumínio no complexo de troca dos ultissolos varia de 1,5 a 6,0 $\mathrm{cmol}_{\mathrm{c}} \mathrm{kg}^{-1}$, portanto, normalmente, superior ao dos oxissolos que apresentam valores inferiores a 3,0 $\mathrm{cmol}_{\mathrm{c}} \mathrm{kg}^{-1}$. Devido à baixa CTC efetiva e ao elevado teor de alumínio, o complexo de troca fica saturado com este íon; assim, é comum observar-se nos solos da Amazônia o caráter álico.

Com relação aos micronutrientes, admite-se que as condições de acidez que prevalecem na região favoreçam a disponibilidade do cobre, ferro, manganês e do zinco e dificultem a do molibidênio. Entretanto, a pluviosidade elevada favorece a lixiviação do $\mathrm{Cu}$ e do $\mathrm{Mn}$ disponíveis, pois tanto a forma iônica quanto os quelatos solúveis formados com a matéria orgânica são lavados facilmente (Malavolta, 1987). Segundo Nicholaides et al. (1983), 23\% dos solos da Amazônia apresentam deficiência de cobre e $48 \%$ mostram-se deficientes em zinco. Estudando a disponibilidade desses micronutrientes em classes de solos dominantes do trópico úmido brasileiro, Singh \& Möller (1984) encontraram deficiência generalizada de $\mathrm{Zn}$ nos solos PV, LA, LV e AL e de Cu (Singh, 1984b) nos PV e LA, geralmente de textura grosseira. Singh (1984a) estudou também a disponibilidade do Mn nos mesmos solos utilizados nos dois trabalhos anteriores, classificando-os como Mn-pobre (LA, AL e PV) e Mn-rico (TE, GPH e LV). Com relação ao Fe total, a sequência encontrada nesses solos foi: $\mathrm{TE}>\mathrm{GPH}>\mathrm{LV}>\mathrm{LA}$ $>$ PV > AL (Singh, 1984c).

Arkcoll (1982) fornece dados sobre as reservas de nutrientes (N, P, K, $\mathrm{Ca}, \mathrm{Mg}, \mathrm{S}, \mathrm{Fe}, \mathrm{Cu}, \mathrm{Mn}, \mathrm{Zn}$ e B) nos solos da Amazônia. Observou também que, comparativamente, os solos do ecossistema de terra firme (areias quartzosas, latossolos 
de floresta e latossolos cultivados) são consideravelmente mais pobres em nutrientes do que os solos de várzea.

\subsection{Disponibilidade e resposta aos micronutrientes}

O conhecimento da ocorrência, reação e movimento dos micronutrientes no solo é fundamental para a análise de seu comportamento no sistema solo-planta. A ocorrência está muito ligada ao material de origem, ao intemperismo e à ação dos fatores formadores do solo. As reações estão relacionadas com a solubilidade dos minerais que os contêm e com a existência de material orgânico e inorgânico, cujos radicais e superficies propiciam o meio adequado para o controle da disponibilidade $\mathrm{e}$ movimentação desses elementos na solução do solo (Camargo, 1988).

Os micronutrientes $\mathrm{Cu}$ e $\mathrm{Zn}$ são complexados pela matéria orgânica do solo e ocorrem na solução do solo principalmente como complexos solúveis. A disponibilidade desses dois micronutrientes não é controlada por reações de precipitação, ao contrário do $\mathrm{Fe}$ e $\mathrm{Mn}$ cuja solubilidade é largamente governada por reações de precipitação e também por oxidação-redução. A disponibilidade do B é controlada

principalmente pelo $\mathrm{pH}$, pela adsorção à matéria orgânica e pela umidade do solo. A disponibilidade do Mo é fortemente influenciada pelo $\mathrm{pH}$. A calagem tem sido a prática mais usada para aumentar a disponibilidade do Mo, eliminar a toxicidez de $\mathrm{Al}$ e $\mathrm{Mn}$, e diminuir a deficiência de $\mathrm{Fe}$ causada pela interação $\mathrm{Fe}-\mathrm{Mn}$ em certas culturas. A diminuição da disponibilidade de $\mathrm{B}, \mathrm{Cu}$ e $\mathrm{Zn}$ pela calagem ocorre, mas, só é crítica quando o pH se eleva muito acima de 6 ou quando os solos são derivados de material de origem muito pobre (Bataglia, 1988).

Pelo exposto, verifica-se que o conhecimento de certas propriedades e características do solo, como material de origem, minerais primários e secundários dominantes, conteúdo de matéria orgânica, $\mathrm{pH}$, textura, umidade e drenagem, entre outros é de muita importância para se avaliar a disponibilidade dos micronutrientes no solo. Na literatura há pouca informação sobre os solos da Amazônia. Os poucos estudos de avaliação das deficiências e respostas aos nutrientes têm-se restringido quase que 
unicamente a trabalhos com macronutrientes e os trabalhos com micronutrientes são praticamente inexistentes. Um outro aspecto a considerar é a tendência natural de transformação da agricultura itinerante em exploração, que poderá trazer como consequência desequilíbrios nutricionais, onde a disponibilidade de outros nutrientes exigidos em menor quantidade pela planta, como é o caso dos micronutrientes, poderá tornar-se fator limitante da produção.

Em sua revisão sobre os micronutrientes nos solos das regiões úmidas, Drosdoff (1975) cita vários trabalhos sobre deficiência de boro, molibdênio, zinco e outros nas plantações comerciais de café, cacau, seringueira, dendezeiro, cana-de-açúcar, abacaxi, algodão, citrus e outros cultivos extensivos, onde a deficiência de um ou mais desses micronutrientes está se tornando cada vez mais comum.

Estudos realizados sobre a fertilidade dos solos de terra firme nas proximidades de Manaus (EMBRAPA, 1984) mostraram que em áreas recémqueimadas, onde o $\mathrm{pH}$ fica em torno de 5,5, não foram evidenciados problemas sérios de deficiências de micronutrientes durante os três primeiros anos de cultivo do milho e do feijão caupi em Latossolos argilosos. Contudo, observou-se um aumento de produção para o milho de $24 \%$ quando se aplicaram $2 \mathrm{~kg} \mathrm{ha}^{-1}$ de $\mathrm{Cu}$ e de $17 \%$ quando se aplicaram $10 \mathrm{~kg} \mathrm{ha}^{-1}$ de Mn. Em outro experimento no mesmo tipo de solo (EMBRAPA, 1989), não foram observadas respostas significativas à aplicação de $\mathrm{B}, \mathrm{Cu}, \mathrm{Mn}$ e $\mathrm{Zn}$, até o sétimo cultivo em rotação. Entretanto, Singh \& Moller (1984) trabalhando com amostras de solo de diferentes partes do trópico úmido brasileiro, evidenciaram uma generalizada deficiência de zinco em solos derivados de rochas ácidas (PV, LA, LV) e nos solos Aluviais, o que não ocorreu em solos originados de rochas básicas (Terra Roxa Estruturada - TE) ou em solos formados de material sedimentar holocênico ou recente em condições de hidromorfismo (Glei Pouco Húmico - GPH). Segundo os autores há necessidade de serem tomadas medidas preventivas ou corretivas para evitar que a deficiência de zinco nesses solos (LA, LV, AL e PV) possam limitar a produtividade da cultura do arroz de sequeiro. 
Nos últimos anos têm-se observado uma expansão das áreas plantadas com culturas perenes na região Amazônica. $\mathrm{O}$ aumento da produtividade desses cultivos, com o uso de variedades de alto rendimento e a maior utilização de fertilizantes nitrogenados, fosfatados e potássicos, tem acentuado a necessidade de se prestar mais atenção aos micronutrientes. Corroborando com esta observação, Pacheco et al. (1986), estudando mudas de dendê cultivadas em latossolo argiloso no Amazonas, verificaram que a aplicação de uréia e superfosfato triplo (SPT) diminuiu os teores foliares de $\mathrm{Cu}$ e o crescimento das plantas no viveiro. Resultados semelhantes foram encontrados por Rodrigues et al. (1997), em relação ao boro, cobre e zinco, em estudo realizado sobre o mesmo tipo de solo e cultura no campo. As concentrações foliares de $\mathrm{Cu}$ e $\mathrm{Zn}$ foram diminuídas pelas elevações nas doses do SPT e a do B diminuiu na presença de $\mathrm{KCl}$. Em outro estudo, Viégas (1985) verificou que a aplicação de doses de NPK em mudas de seringueira cultivadas em latossolo amarelo textura média no Pará, reduziram os teores de B, Cu e Zn nas folhas. Segundo Bergmann (1992) a aplicação de grandes quantidades de macronutrientes no solo causa o desequilíbrio dos íons na solução do solo em detrimento dos micronutrientes. Isto pode reduzir a absorção de micronutrientes pelas plantas, a menos que o desbalanço seja compensado pelo suprimento do solo ou por fertilizantes contendo esses nutrientes.

\subsection{Métodos de análise para micronutrientes}

O propósito da análise de solos é medir as quantidades dos nutrientes disponiveis para as plantas contidos nos solos, com o objetivo de fornecer parâmetros para o cálculo de recomendação de adubação. Constitui, portanto, o instrumento mais importante com que conta o agricultor para definir o uso eficiente de adubos e corretivos.

A interpretação das análises de solos baseia-se em estudos de correlação e calibração com as respostas das plantas à aplicação de uma quantidade adequada de nutrientes. Para Lopes \& Carvalho (1988) esta é uma das fases mais críticas de um programa de avaliação da fertilidade do solo, tanto para macro como para 
micronutrientes, uma vez que um resultado obtido de uma análise de solo não apresenta nenhum valor "per se", e pode ou não refletir a disponibilidade do nutriente em questão. Assim, os valores obtidos na análise de solos por um determinado método, somente tornam-se utilizáveis quando os mesmos têm correlação com as respostas de produção das culturas. Tais correlações são, em geral, obtidas em duas etapas: uma primeira, considerada exploratória é desenvolvida em casa-de-vegetação com um grande número de solos que apresentam amplas variações em suas propriedades e características, como por exemplo, textura, matéria orgânica, material de origem, etc; e uma segunda etapa, considerada definitiva, conduzida em condições de campo, envolvendo um menor número de solos cuidadosamente selecionados.

Nos experimentos em casa-de-vegetação, faz-se uma comparação do aspecto e da produção da planta submetida a um tratamento chamado "completo" com outros tratamentos nos quais os nutrientes são omitidos um de cada vez: trata-se, portanto, de uma "diagnose por subtração". O método serve, pois, para avaliar a fertilidade do solo e, ao mesmo tempo, pode fornecer uma idéia semi quantitativa da necessidade de adubos. Pode-se fazer, ainda, uma descrição dos sintomas de deficiências da planta-teste (Malavolta, 1980).

A diponibilidade de um nutriente pode ser associada ou correlacionada com valores, geralmente obtidos por métodos de extração química, que dão uma indicação da fertilidade do solo. A dificuldade do estabelecimento desses valores de referência é relativamente maior para os micronutrientes, por causa da baixa ocorrência e dos mecanismos que governam as reações de disponibilidade. O conhecimento dos fatores envolvidos é de interesse primordial para a avaliação do estado nutricional das plantas e para definir o manejo do solo a fim de corrigir distúrbios nutricionais por deficiências ou excessos, visando a produtividade das plantas cultivadas (Bataglia, 1988).

Admite-se que uma solução extratora para ser eficiente deve extrair toda ou grande parte das formas de nutrientes no solo que estão disponíveis para as plantas; as quantidades extraídas pela solução usada devem ter uma boa correlação com àquelas absorvidas pela planta e com o crescimento vegetal; e o método de laboratório que 
envolve esta extração deve ser rápido, preciso e com um custo de execução baixo. Assim, uma solução extratora que cumpra estas características, tem preferência para diagnosticar a fertilidade de um solo e a necessidade de nutrientes pelos cultivos.

De acordo com Lindsay \& Cox (1985), os níveis dos micronutrientes na solução do solo são geralmente muito baixos, o mesmo ocorrendo com as quantidades adsorvidas nos sítios de troca. Por esse motivo, a maioria das soluções extratoras para micronutrientes contém ácidos, bases, complexantes ou quelatos que também dissolvam parte dos sólidos na fase lábil. Ácidos diluídos têm sido usados em solos ácidos, enquanto bases, tais como carbonatos e bicarbonatos, são utilizados em solos alcalinos. No caso dos solos cauliníticos, altamente intemperizados e ácidos, os autores observam que, talvez, o uso de um extrator mais forte, tamponado a valores mais baixos de $\mathrm{pH}$, projetado para simular o ambiente das plantas que se desenvolvem em solos mais ácidos, seria mais recomendável.

Segundo Viets \& Lindsay (1973), as soluções complexantes ou agentes quelantes têm se constituído num dos métodos mais promissores para a extração de micronutrientes de caráter catiônico. Lindsay \& Norvell (1978) descrevem um método de análise de solo para micronutrientes com o complexante DTPA (ácido dietilenotriaminopentaacético), após terem-no usado por 10 anos nas determinações de $\mathrm{Cu}, \mathrm{Fe}, \mathrm{Mn}$ e $\mathrm{Zn}$. Segundo Lindsay \& Cox (1985), os quelantes têm sido usados mais extensivamente em solos alcalinos contudo, estudos de seu uso em solos ácidos indicam que podem também ser utilizados nesses solos. Os mesmos autores concluem, ainda, que as limitações em relação aos quelantes são muito mais um problema de calibração para esses tipos de solos do que do próprio extrator.

Um dos maiores problemas para a avaliação da disponibilidade de micronutrientes na produção de culturas tropicais e subtropicais tem sido o grande número de métodos de extração atualmente em uso, pois as comparações com base em diferentes métodos de análise são praticamente impossíveis. Por outro lado, um outro aspecto a considerar é a necessidade de avaliação dos mesmos para extração simultânea 
de vários micronutrientes, o que aumentaria, sem dúvida, a aplicabilidade destes às análises de rotina (Lopes \& Carvalho, 1988).

\subsubsection{Boro}

Muitos métodos têm sido idealizados para estimar o nível de disponibilidade de boro no solo. Entretanto, o método mais usado até hoje, é o de extração com água quente, proposto há meio século por Berger \& Truog (1939). O procedimento consiste, segundo Raij \& Bataglia (1988), na extração de solo com água, na relação $1: 2$, após fervura por 5 minutos, sob refluxo para evitar perda de água, e filtragem imediata. O método prevê a adição de algumas gotas de cloreto de cálcio $\left(\mathrm{CaCl}_{2}\right)$ para flocular partículas coloidais em suspensão e permitir a obtenção de extratos límpidos. Desta forma, a extração com $\mathrm{CaCl}_{2} 0,01 \mathrm{M}$ equivale à extração com água, uma vez que a presença do sal parece não afetar a extração do boro. Reisenauer et al. (1973) citam vários autores que, usando esse método, obtiveram correlações significativas para as culturas de alfafa, trigo, girassol, milho, algodão e nabo.

O método de extração com água quente ainda apresenta sérias limitações nas análises de rotina, principalmente por tratar-se de um método trabalhoso, demorado e de custo relativamente elevado. Assim, buscando a simplificação do método, vários trabalhos foram desenvolvidos, apresentando bons resultados (Gupta, 1967; Catani et al., 1970; Mahler et al.,1984; Abreu et al., 1994).

Alternativas mais simples, utilizando soluções diluídas de ácidos e sais são freqüentemente propostas e comparadas com a água quente como índices de disponibilidade de boro, com as vantagens de possibilitar o procedimento simples e barato, além de servir para extração conjunta de outros nutrientes do solo. Em trabalhos realizados por Bartz \& Magalhães (1975) e Cruz \& Ferreira (1984) os extratores ácidos $\mathrm{HCl} 0,05 \mathrm{~N}, \mathrm{H}_{2} \mathrm{SO}_{4} 0,05 \mathrm{~N}$ e ácido acético apresentaram eficiência semelhante à do extrator água quente. Entretanto, Bataglia \& Raij (1990), estudando a eficiência de extratores na determinação de boro em 26 solos do estado de São Paulo, verificaram que o extrator Mehlich $\left(\mathrm{HCl} 0,05 \mathrm{M}+\mathrm{H}_{2} \mathrm{SO}_{4} 0,125 \mathrm{M}\right)$ foi menos eficiente que a água quente, 
mostrando um coeficiente de correlação baixo com absorção de boro pelo girassol, mesmo com a inclusão de outros parâmetros do solo, como o pH, argila, matéria orgânica e capacidade de troca. O extrator Mehlich-1 também não conseguiu discriminar o efeito da calagem em baixos níveis de boro no solo. Já a extração com solução de $\mathrm{CaCl}_{2}$ 0,01M em bloco digestor mostrou-se viável, apresentando resultados semelhantes aos obtidos com água quente.

O B extraído por estes extratores pode ser analisado por diferentes métodos. Um procedimento que tem sido preferencialmente utilizado por muitos especialistas é o que envolve a formação do complexo colorido do $\mathrm{H}_{3} \mathrm{BO}_{3}$ com azometina-H em meio aquoso. Outro método bastante usado é o da curcumina (Raij at al., 1987).

\subsubsection{Cobre, ferro, manganês e zinco}

Muitos laboratórios têm preferido o uso de quelatos para extrair os metais $\mathrm{Cu}, \mathrm{Fe}, \mathrm{Mn}$ e $\mathrm{Zn}$ do solo, pois os quelatos tendem a simular a remoção dos nutrientes pelas plantas e a reposição destes para a solução pela fase sólida do solo. Outra vantagem atribuída aos quelatos é que o $\mathrm{pH}$ de extração pode ser mantido mais próximo daquele do solo, o que pode ser um fator importante para a determinação de micronutrientes cujas solubilidades dependem da reação do solo. Entre os quelatos descritos na literatura para a extração desses micronutrientes, destacam-se a ditizona tamponada a pH 7,0 com $\mathrm{NH}_{4} \mathrm{OAc}$; o EDTA (ácido dietilenodiaminotetraacético) em várias concentrações e geralmente tamponado próximo da neutralidade e o DTPA (ácido dietilenotriaminopentaacético) em trietanolamina, tamponado a pH 7,3 (Raij et al.1987).

Em geral, no Brasil, os extratores mais usados têm sido as soluções de $\mathrm{HCl}$ e os quelatos (EDTA e DTPA). Assim, pelos dados disponíveis na literatura, há evidências de que as soluções ácidas se comportaram com eficiência em vários estudos, porém, não são raras as ocorrências de melhores respostas obtidas com soluções complexantes. 
Camargo et al. (1982) estudaram os efeitos do $\mathrm{pH}$ e da incubação na extração de $\mathrm{Cu}, \mathrm{Fe}, \mathrm{Mn}$ e $\mathrm{Zn}$ pelo extrator Mehlich $\left(\mathrm{HCl} 0,05 \mathrm{~N}+\mathrm{H}_{2} \mathrm{SO}_{4} 0,025 \mathrm{~N}\right)$ e DTPA-TEA pH 7,3 em solos paulistas com ampla faixa de variação nas suas características. Concluíram que o DTPA-TEA consegue discriminar bem o comportamento do $\mathrm{Cu}, \mathrm{Fe}$ e $\mathrm{Mn}$ com relação ao $\mathrm{pH}$ e calagem, e razoavelmente o do $\mathrm{Zn}$; os teores dos quatro micronutrientes analisados diminuíram com a elevação do pH e com a incubação com água para a maioria dos solos analisados. Por outro lado, o extrator de Mehlich não foi capaz de discriminar satisfatoriamente a influência desses dois fatores. Em estudo mais recente, Buzetti (1992) avaliou a eficiência dos extratores DTPA $0,005 \mathrm{M} \mathrm{pH} 7,3, \mathrm{HCl} 0.05 \mathrm{~N}+\mathrm{H}_{2} \mathrm{SO}_{4} 0,025 \mathrm{~N}$ e $\mathrm{HCl} 0,1 \mathrm{~N}$ para o zinco. Os extratores testados mostraram a mesma eficiência na extração do zinco do solo e apresentaram boa correlação com o zinco contido na parte aérea do milho. $\mathrm{O}$ autor observou ainda, que não houve diferença significativa entre os coeficientes de correlação quando se confrontaram os extratores utilizados, mesmo discriminando os tratamentos que receberam ou não corretivos.

Dentre os métodos de extração ácida, o Mehlich-3 $\left(\mathrm{CH}_{3} \mathrm{COOH} 0,2 \mathrm{~N}\right.$; $\mathrm{NH}_{4} \mathrm{NO}_{3} \quad 0,25 \mathrm{~N} ; \mathrm{NH}_{4} \mathrm{~F} \quad 0,015 \mathrm{~N} ; \mathrm{HNO}_{3} 0,013 \mathrm{~N}$ e EDTA $0,001 \mathrm{M}$ ) foi considerado como o procedimento mais apropriado e econômico para análise de solo em laboratório, devido à sua capacidade de extrair do solo, simultaneamente vários nutrientes como $\mathrm{P}$, $\mathrm{K}, \mathrm{Ca}, \mathrm{Mg}, \mathrm{Na}, \mathrm{B}, \mathrm{Cu}, \mathrm{Fe}, \mathrm{Mn}$ e Zn (Tran et al., 1990). Este método foi adaptado a partir do extrator Mehlich-2. Assim, algumas modificações foram realizadas no Mehlich2 para obtenção do Mehlich-3, em virtude de observações feitas durante o processo de extração. Foi o caso da ação do íon cloreto, que apresentou propriedades corrosivas durante a extração, indicando a necessidade de mudança dos compostos que possuem este íon, de modo a reduzir o perigo de corrosão nos materiais e equipamentos de laboratório. Dessa maneira, no extrator Mehlich-3, os íons cloretos foram substituídos por nitratos. A incorporação de EDTA no extrator, teve por finalidade melhorar a extração dos micronutrientes. A adição do EDTA aumentou as extrações do $\mathrm{Cu}$ em 170\%, Mn em 50\% e Zn em 25\% (Mehlich, 1984). 
Em estudos mais abrangentes, coordenados por Sillanpää (1982) em cooperação com 30 países, foram avaliados os teores de $\mathrm{Cu}, \mathrm{Fe}, \mathrm{Mn}$ e $\mathrm{Zn}$ no solo através do método acetato ácido de amônio - EDTA (AAAc - EDTA) a pH 4,65 e do DTPA a $\mathrm{pH} 7,3$, utilizando milho e trigo como plantas testes. No caso do ferro, não se obtiveram boas correlações entre a concentração desse micronutriente nas plantas crescendo no campo e os niveis extraídos pelos dois métodos. Isto ocorreu porque as deficiências de Fe são geralmente restritas a solos de $\mathrm{pH}$ alto, independente da mineralogia e também devido à grande variabilidade da amostragem de campo, condições de crescimento e manuseio das amostras, principalmente em relação à possivel contaminação das amostras de plantas. Os dois métodos mostraram-se igualmente efetivos para $\mathrm{Zn}$ e $\mathrm{Cu}$; entretanto, para o Mn, o DTPA foi significativamente superior ao AAAc-EDTA. Identificou-se também, que dentre os fatores do solo que mais influenciaram a correlação entre os resultados das análises de solo e a de planta, para $\mathrm{Mn}$ e $\mathrm{Zn}$, o mais importante foi o $\mathrm{pH}$; para o $\mathrm{Cu}$ foi o carbono orgânico e para o B foi a CTC.

Segundo Sims \& Johnson (1991), o uso do EDTA na extração de vários elementos, tal como o Mehlich-3, Olsen modificado e AAAc-EDTA associado com medidas das propriedades do solo, podem resultar num prognóstico eficaz das deficiências de micronutrientes, particularmente nos solos ácidos.

\subsubsection{Molibdênio}

A disponibilidade do Mo nos solos tem sido pouco estudada devido, principalmente, à pequena ocorrência de deficiências, associadas às baixas concentrações desse elemento no solo, ao pequeno requerimento pelas plantas e à utilização, cada vez maior, de corretivos da acidez do solo.

Vários métodos tem sido propostos para medir a disponibilidade do Mo, incluindo a extração com água quente, $\mathrm{NH}_{4} \mathrm{OAc}$, oxalato de amônio e resina trocadora de ânions. Para os três primeiros extratores, a inclusão dos valores de $\mathrm{pH}$ do solo na interpretação dos resultados ajudou a melhorar a correlação entre o Mo extraído e a absorção do elemento por plantas (Raij et al., 1987). Entretanto, ainda não existe análise 
de rotina para o molibdênio. O oxalato de amônio a pH 3,3 (Grigg, 1953) ainda é o extrator mais comumente usado (Lindsay \& Cox, 1985).

Vários fatores do solo afetam a quantidade de Mo disponível para as plantas. Sillanpää (1982) estudou o efeito de vários parâmetros do solo sobre a disponibilidade do Mo extraído pela solução de oxalato de amônio - ácido oxálico (AO$\mathrm{OA})$ a $\mathrm{pH} \mathrm{3,3} \mathrm{e} \mathrm{verificou} \mathrm{que} \mathrm{o} \mathrm{pH}$ foi o mais importante. De modo geral, a ordem de importância apresentada por esses fatores em relação aos conteúdos de Mo nos solos e nas plantas foi: $\mathrm{pH}>$ equivalente de $\mathrm{CaCO}_{3}>$ condutividade elétrica $>$ carbono orgânico $>$ textura $>$ CTC.

O Mo extraído pode ser determinado por colorimetria através da formação do complexo Mo-tiocianato. Outras possibilidades são o uso de espectrofotometria de absorção atômica com forno de grafite e espectroscopia de emissão em plasma de argônio (Kubota \& Cary, 1982). Buscando a inclusão do Mo nas análises de rotina, novos métodos de extração e determinação desse elemento têm sido testados. Dentro dessa perspectiva, o AB-DTPA (bicarbonato de amônio - ácido dietilenotriaminopentaacético) desenvolvido para ser usado com o espectrômetro de emissão atômica com plasma de argônio (ICP-AES), apresenta a vantagem de extrair simultaneamente vários elementos, entre eles o Mo (Soltanpour \& Schwab, 1977; Soltanpour \& Workman, 1979; Soltanpour, 1991). 


\section{MATERIAL E MÉTODOS}

\subsection{Local}

Os experimentos foram instalados e conduzidos em casa de vegetação do Centro de Energia Nuclear na Agricultura - CENA, "Campus" de Piracicaba - USP, Estado de São Paulo.

\section{2 Solo}

As amostras de solos foram coletadas, visando abranger classes de solos com textura variável, considerando-se o teor de argila e em localidades onde a agricultura é utilizada de forma mais intensiva. Por outro lado, para reduzir possíveis interferências nos resultados, foi dada preferência a solos sob vegetação natural.

As amostras foram coletadas na camada de $0-20 \mathrm{~cm}$, destorroadas, secas ao ar e passadas em peneiras com malha de $4 \mathrm{~mm}$ de abertura (TFSA). Subamostras foram retiradas e passadas em peneiras com malha de $2 \mathrm{~mm}$ de abertura para a caracterização física, química e mineralógica.

Como recipientes foram usados vasos plásticos com capacidade para 500 $\mathrm{mL}$, com fundo perfurado e dotados de coletores para drenagem. Os vasos foram pintados externamente com tinta de alumínio. Utilizou-se $300 \mathrm{~g}$ de solo e $0,16 \mathrm{dm}^{3} \mathrm{de}$ quartzo moído, previamente lavado, sendo que $0,07 \mathrm{dm}^{3}$ do quartzo moído colocou-se no fundo do copo e $0,09 \mathrm{dm}^{3}$ sobre o solo, com o objetivo de melhorar a drenagem e evitar a formação de crostas. 
As análises granulométricas foram feitas com base no método da pipeta e do densímetro (EMBRAPA, 1979), utilizados no laboratório de física de solo da Escola Superior de Agricultura "Luiz de Queiroz"- USP. A classificação textural realizada de acordo com a SOCIEDADE BRASILEIRA DE CIÊNCIA DO SOLO (1967). A densidade do solo, a densidade de partículas e a porosidade total foram determinadas conforme descrito pela EMBRAPA (1979).

$\mathrm{Na}$ caracterização química inicial das amostras de solo determinou-se:

a) Os óxidos $\left(\mathrm{SiO}_{2}, \mathrm{Al}_{2} \mathrm{O}_{3}, \mathrm{Fe}_{2} \mathrm{O}_{3}, \mathrm{TiO}_{2}\right)$ - obtidos pelo ataque sulfúrico foram efetuadas conforme Vettori (1969);

b) Os teores totais dos nutrientes (P, Ca, Mg, B, Cu, Fe, Mn e Zn) - obtidos pelo ataque perclórico-fluorídrico (Camargo et al., 1986) e determinados por espectrometria de emissão atômica com plasma de argônio (ICP-AES), exceto para o potássio e o sódio que foram determinados por fotometria de chama;

c) pH em $\mathrm{H}_{2} \mathrm{O}$, pH em $\mathrm{CaCl}_{2} 0,01 \mathrm{~mol} \mathrm{~L}^{-1}$ e pH em $\mathrm{KCl} 1,0 \mathrm{~mol} \mathrm{~L}^{-1}$ determinado em potenciômetro com eletrodo de vidro, empregando-se a relação solo:solução 1:2,5 (EMBRAPA, 1979);

d) Matéria orgânica - pelo método colorimétrico (Quaggio \& Raij, 1979);

e) $\mathbf{P}, \mathbf{K}, \mathbf{C a}, \mathbf{M g}$ disponível - extraído pelo método da resina, sendo o $\mathrm{P}$ determinado por fotocolorimetria, o $\mathrm{K}$ por fotometria de chama e o $\mathrm{Ca}$ e $\mathrm{Mg}$ por espectofotometria de absorção atômica;

f) Sódio - extraído com $\mathrm{NH}_{4} \mathrm{OA}_{\mathrm{c}} 0,05 \mathrm{~mol} \mathrm{~L}^{-1}+\mathrm{H}_{2} \mathrm{SO}_{4} 0,025 \mathrm{~mol} \mathrm{~L}^{-1} \mathrm{e}$ determinado por fotometria de chama;

g) $\mathbf{S}_{-} \mathrm{SO}_{4}{ }^{2-}$ - extraído com $\mathrm{NH}_{4} \mathrm{OA}_{\mathrm{c}} 0,5 \mathrm{~mol} \mathrm{~L}^{-1}$ em $\mathrm{HOA}_{\mathrm{c}} 0,25 \mathrm{~mol} \mathrm{~L}^{-1} \mathrm{e}$ determinado por turbidimetria do sulfato de bário (Vitti, 1989);

h) Al trocável - extraído com $\mathrm{KCl} 1 \mathrm{~mol} \mathrm{~L}^{-1}(1: 5)$ e determindo por titulometria com uma solução de $\mathrm{NaOH} 0,25 \mathrm{~mol} \mathrm{~L}^{-1}$ padronizada, usando o azul de bromotimol como indicador (Raij et al., 1987);

i) Acidez potencial $\left(\mathbf{H}^{+}+\mathbf{A l}^{3+}\right)$ - determinado potenciométricamente pela solução tampão SMP (Raij et al, 1987); 
j) Boro - extraído com $\mathrm{CaCl}_{2} \cdot 2 \mathrm{H}_{2} \mathrm{O} 0,1 \%(1: 2)$ e quantificado por colorimetria da azometina H (Cruz \& Ferreira, 1984);

1) Cobre, ferro, manganês e zinco - extraído com DTPA-TEA (ácido dietilenotriaminopentaacético - trietanolamina), tamponado a pH 7,3 (Raij et al.1987).

A composição mineralógica da fração argila e silte foi determinada no laboratório de mineralogia da Escola Superior de Agricultura "Luiz de Queiroz"- USP , através da técnica de raios- $X$, segundo Jackson (1979).

\section{3 Planta}

A variedade de arroz (Oriza sativa $\mathrm{L}$ ) usada como planta-teste foi a IAC165, proveniente do Instituto Agronômico de Campinas (IAC).

\section{4 Tratamentos}

Usou-se o diagnóstico por subtração, descrito por Malavolta et al. (1993), adaptado à técnica de Sillanpãã (1982), a qual foi por ele empregada no estudo mundial de disponibilidade de micronutrientes. Utilizou-se o delineamento experimental blocos casualizados, com três repetições, constituído pelos fatores:

a) Fator solo - 10 classes de solos: 2 latossolos amarelos álicos textura muito argilosa (LA-1 e LA-2); 1 latossolo amarelo distrófico textura média (LA-3); 1 podzólico amarelo álico textura arenosa (PA-1); 1 podzólico amarelo álico textura média (PA-2); 1 podzólico vermelho-amarelo álico textura argilosa (PV); 2 podzóis álicos textura arenosa (Podzol-1 e Podzol-2); 1 aluvial Tb eutrófico textura siltosa (AL); 1 latossolo húmico antropogênico distrófico textura argilosa $(\mathrm{LH})$.

b) Fator tratamento: 1 - Testemunha absoluta (solo original, sem aplicação de nutrientes)

2 - Completo (N, P, K, Ca, Mg, S, B, Cl, Cu, Fe, Mn, Mo e Zn)

3 - Completo com a omissão de boro (-B)

4 - Completo com a omissão de cobre $(-\mathrm{Cu})$

5 - Completo com a omissão de ferro (-Fe) 
6 - Completo com a omissão de manganês (-Mn)

7 - Completo com a omissão de molibdênio (-Mo)

8 - Completo com a omissão de zinco (-Zn)

Para facilitar a condução do experimento (pesagem dos vasos para controle da umidade, visualização de sintomas de deficiência, etc), utilizaram-se parcelas subdivididas. Na casualização foram fixados os solos (parcela) e sortearam-se os tratamentos (subparcelas): 10 solos, 8 tratamentos com 3 repetições, perfazendo um total de 240 vasos.

\section{5 Primeiro cultivo}

\section{5. 1 Fornecimento de nutrientes e incubação das amostras de solo}

Na Tabela 1 são apresentados os nutrientes utilizados nas adubações, fornecidos como produtos pró-análise. A correção do solo foi feita buscando-se uma saturacão por bases de 50\%, com uma relação $\mathrm{Ca}: \mathrm{Mg}$ de 3:1. O fósforo, 1/3 do potássio e os micronutrientes foram adicionados aos solos junto com a calagem. $\mathrm{O}$ solo ficou incubando durante 30 dias com umidade próxima de $70 \%$ da capacidade de campo, que foi determinada pelo método TSFM (Torrão Separado pela Frente de Molhamento), descrito por Costa (1983). Um 1/3 do nitrogênio foi aplicado no momento do plantio. Os 2/3 restantes de $\mathrm{N}$ e de $\mathrm{K}$ foram parcelados em duas aplicações realizadas aos 28 e 40 dias após a germinação.

Amostras de solo foram coletadas após o período de incubação e analisadas quimicamente. O ensaio teve início no final do mês de agosto de 1996. 


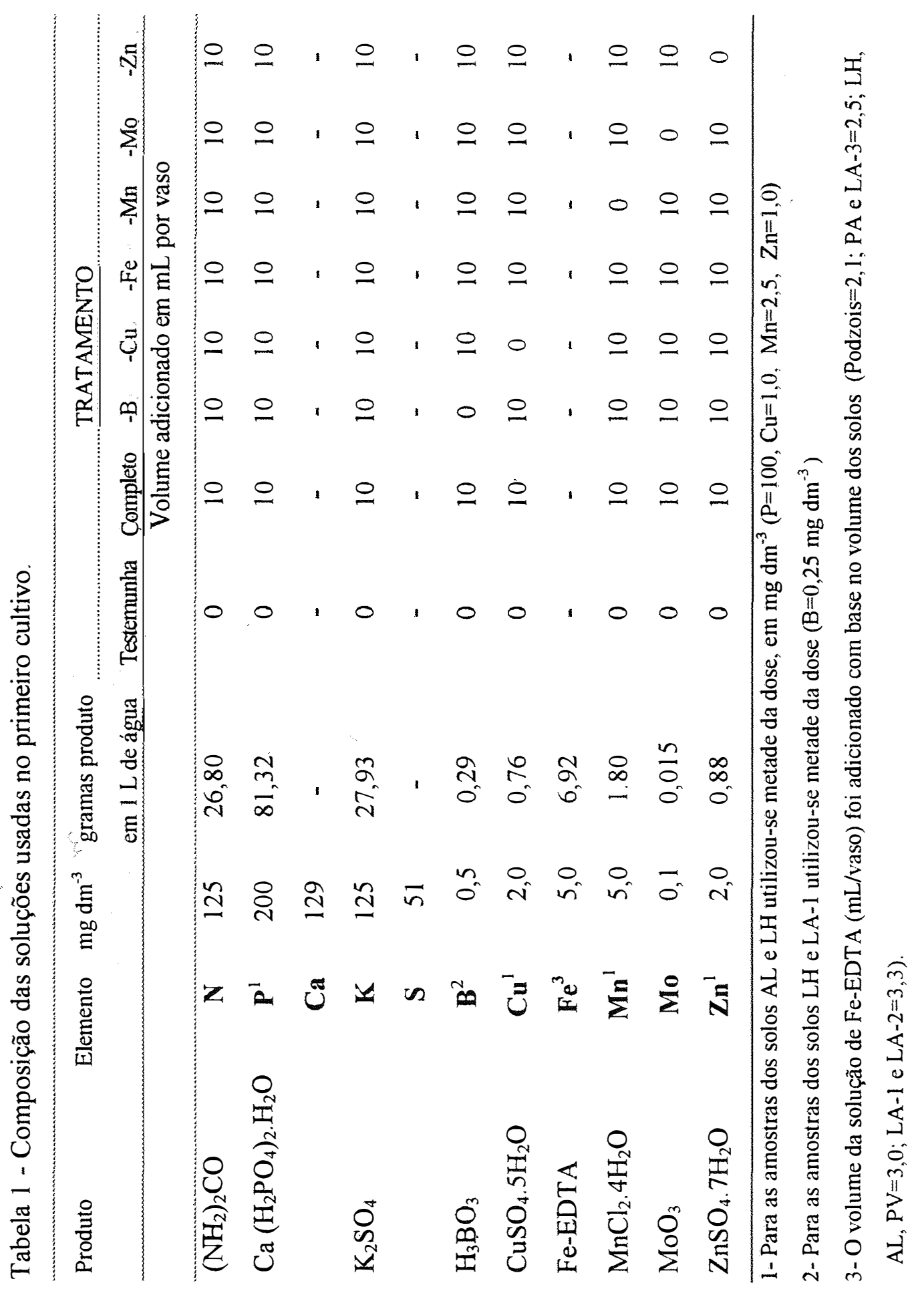




\section{5.2 Condução}

Doze sementes de arroz da variedade IAC-165 foram colocadas para germinar na profundidade de $1 \mathrm{~cm}$. Após o desbaste, ficaram 8 plantas por vaso. A umidade do solo foi mantida em torno de 60 a 70\% da capacidade de campo durante todo o período de cultivo através de reposições diárias de água destilada, baseadas em pesagens, enquanto o desenvolvimento das plantas não afetou demasiadamente o peso dos vasos. Depois desse período, a água destilada continuou sendo colocada sempre que necessária, tomando-se cuidado para evitar falta ou encharcamento.

A colheita das plantas foi realizada aos 58 dias após o período de emergência das plântulas, cortando-se a parte aérea rente à superficie do solo. Após pesagem, o material vegetal foi lavado com água destilada, acondicionado em sacos de papel e levado para secar em estufa de circulação de ar forçada, na temperatura de 60$70^{\circ} \mathrm{C}$, até peso constante. Depois de obtido o peso da matéria seca produzida, o material foi moído e acondicionados em saquinhos de papel, para posterior análise química.

Após a secagem dos solos, estes foram passados em peneira de $2 \mathrm{~mm}$ de abertura para permitir a retirada das raízes e coleta de subamostras. As raízes foram lavadas com água destilada, acondicionadas em sacos de papel e levadas para secar em estufa de circulação de ar forçada, na temperatura de $60-70^{\circ} \mathrm{C}$, até peso constante. As subamostras de solo (em torno de 30 gramas) foram peneiradas e armazenadas em sacos plásticos, para determinação do teor dos nutrientes.

\section{6 Segundo cultivo}

Visando avaliar o potencial de suprimento e poder residual dos micronutrientes dos solos em estudo, realizou-se um segundo cultivo, utilizando-se o mesmo solo de cada vaso, isto é, eles foram novamente acondicionados em seus respectivos vasos, seguindo a mesma sequência (quartzo moído $\rightarrow$ solo $\rightarrow$ quartzo moído).

O segundo cultivo teve início em fevereiro de 1997. Foram mantidas 10 plantas por vaso da mesma variedade. Tanto na instalação como na condução 
foram tomados, basicamente, os mesmos procedimentos já descritos para o primeiro cultivo, com exceção da calagem e aplicação dos micronutrientes que não foram realizadas. No plantio, efetuou-se apenas uma adubação básica de manutenção, na forma de solução, com fosfato monoamônio $\left(\mathrm{NH}_{4} \mathrm{H}_{2} \mathrm{PO}_{4}\right)$, fornecendo $100 \mathrm{mg}$ de $\mathrm{P}$ e $44 \mathrm{mg}$ de $\mathrm{N}$ para as amostras dos solos LA-1, LA-2, LA-3, PA-1, PA-2, PV, e $50 \mathrm{mg}$ de $\mathrm{P}$ e $22 \mathrm{mg}$ de $\mathrm{N}$ para o AL e o LH. A diferença com relação ao $\mathrm{N}$ para estas duas amostras de solos foi completada com a aplicação de $22 \mathrm{mg}$ de $\mathrm{N}$ na forma $\mathrm{NH}_{4} \mathrm{NO}_{3}$. Também na forma de solução, adicionou-se $50 \mathrm{mg}$ de $\mathrm{K}$, tendo como fonte o sulfato de potássio $\left(\mathrm{K}_{2} \mathrm{SO}_{4}\right)$. Durante o desenvolvimento das plantas, realizou-se mais 3 aplicações de $\mathrm{N}$ e $\mathrm{K}$ : na primeira aplicou-se $50 \mathrm{mg}$ de $\mathrm{K}$ na forma de $\mathrm{K}_{2} \mathrm{SO}_{4}$ e $50 \mathrm{mg}$ de $\mathrm{N}$ na forma de $\mathrm{NH}_{4} \mathrm{NO}_{3}$ : na segunda e na terceira aplicou-se, em cada uma, $25 \mathrm{mg}$ de $\mathrm{N}$ na forma de $\left(\mathrm{NH}_{2}\right)_{2} \mathrm{CO}$ e $25 \mathrm{mg}$ de $\mathrm{K}$ na forma de $\mathrm{K}_{2} \mathrm{SO}_{4}$. A colheita das plantas foi realizada aos 68 dias após a emergência das plântulas.

\section{7 Terceiro cultivo}

Com o objetivo de promover um maior esgotamento dos nutrientes do solo, realizou-se o terceiro cultivo, com início em junho de 1997, mantendo-se 17 plantas por vaso. Em linhas gerais foi feito como o segundo, exceto no que tange à adição dos macronutrientes, em que as doses $\left(\mathrm{mg} \mathrm{dm}^{-3}\right)$ no plantio foram: $\mathrm{N}=50\left(\left(\mathrm{NH}_{2}\right)_{2} \mathrm{CO}\right)$, $\mathrm{P}=100\left(\mathrm{NH}_{4} \mathrm{H}_{2} \mathrm{PO}_{4}\right), \mathrm{K}=50\left(\mathrm{~K}_{2} \mathrm{SO}_{4}\right)$. Durante o desenvolvimento das plantas, realizou-se mais 4 aplicações de $25 \mathrm{mg} \mathrm{dm}{ }^{-3}$ cada, para $\mathrm{N}\left(\left(\mathrm{NH}_{2}\right)_{2} \mathrm{CO}\right.$ e para $\mathrm{K}\left(\mathrm{K}_{2} \mathrm{SO}_{4}\right)$. A colheita das plantas foi realizada aos 70 dias após a emergência das plântulas.

\subsection{Métodos químicos de análise das amostras de solo}

Os teores disponíveis dos nutrientes nas amostras de solo coletadas após incubação, antes de realizar-se o primeiro cultivo e após a realilização do primeiro, segundo e terceiro cultivo, foram analisados utilizando-se os seguintes extratores:

a) Água quente - a extração do boro disponível utilizando o forno de microondas seguiu a metodologia proposta por Abreu et al. (1994) $-10 \mathrm{~cm}^{-3}$ de TFSA, $20 \mathrm{~mL}$ da 
solução de cloreto de bário $\left(\mathrm{CaCl}_{2} .2 \mathrm{H}_{2} \mathrm{O}\right)$ a $0.125 \%$ e $0.5 \mathrm{~cm}^{3}$ de carvão ativado foram colocados em sacos de polipropileno $(15 \mathrm{~cm} \times 25 \mathrm{~cm})$ e vedados; fez-se um pequeno furo no canto superior dos sacos para diminuir a pressão durante o aquecimento. Os mesmos foram pendurados na pratileira giratória e aquecidos por um período de 4 minutos na potência de 700 watts. Após um repouso de 30 minutos para esfriar, a suspensão foi filtrada em papel de filtro Whatman 42 . Transferiu-se uma alíquota de $4 \mathrm{~mL}$ do extrato e da solução tampão para frascos plásticos de $50 \mathrm{~mL}$ e homogenizou-se. Adicionou-se 1 $\mathrm{mL}$ da solução de azometina-H a $0,9 \%$ e agitou-se. Após 30 minutos tansferiu-se as soluções para tubos de colorímetro e procedeu-se às leituras com filtro azul (420 nm), acertando o zero do espectrofotômetro com a solução de cloreto de bário a $0.125 \%$. O cálculo dos teores de boro no solo foram realizados com base na equação de regressão obtida da leitura da absorbância de soluções padrões. A solução tampão foi guardada em frasco plástico no refrigerador, enquanto a de cloreto de bário a $0.125 \%$ e de azometina$\mathrm{H}$ a $0,9 \%$ foram preparadas diariamente. Durante todo o procedimento utilizaram-se recipientes plásticos livres de boro, inclusive para o preparo da curva padrão.

b) Mehlich 1 - modificado pela EMBRAPA (1997). Colocaram-se em frascos plásticos de $100 \mathrm{~mL} 5 \mathrm{~cm}^{-3}$ de TFSA com $25 \mathrm{~mL}$ de uma solução mista de ácidos (Hcl $0.05 \mathrm{~mol} \mathrm{~L}^{-1}+\mathrm{H} 2 \mathrm{SO} 40.025 \mathrm{~mol} \mathrm{~L}^{-1}$ ) e agitados por 5 minutos, em agitador horizontal (200 agitações por minuto); a suspensão foi filtrada em papel de filtro Whatman 42. No extrato obtido determinou-se a disponibilidade dos nutrientes $\mathrm{P}, \mathrm{Ca}, \mathrm{Mg}, \mathrm{B}, \mathrm{Cu}, \mathrm{Fe}, \mathrm{Mn}$ e $\mathrm{Zn}$ por espectrometria de emissão atômica com indução de plasma de argônio (ICP-AES) e o K pelo fotômetro de chama. Durante todo o procedimento foram utilizados recipientes plásticos livres de boro.

c) Mehlich 3 - conforme método descrito por Mehlich (1984) - agitaram-se 2,5 $\mathrm{cm}^{-3}$ de TFSA com $25 \mathrm{~mL}$ da solução extratora Mehlich-3 $\left(\mathrm{CH}_{3} \mathrm{COOH} 0,2 \mathrm{~N} ; \mathrm{NH}_{4} \mathrm{NO}_{3}\right.$ $0,25 \mathrm{~N} ; \mathrm{NH}_{4} \mathrm{~F} 0,015 \mathrm{~N} ; \mathrm{HNO}_{3} 0,013 \mathrm{~N}$ e EDTA $0,001 \mathrm{M}$ ) por 5 minutos, em agitador horizontal (200 agitações por minuto). O extrato obtido foi filtrado em papel de filtro Whatman 42 e nele determinou-se a disponibilidade dos nutrientes $\mathrm{P}, \mathrm{Ca}, \mathrm{Mg}, \mathrm{Cu}, \mathrm{Fe}, \mathrm{Mn}$ 
e $\mathrm{Zn}$ por espectrometria de emissão atômica com indução de plasma de argônio (ICPAES).

d) DTPA-TEA (ácido dietileno triamino pentaacético-trietanolamina) tamponado a pH 7,3, segundo a metodologia proposta por Lindsay \& Norvell (1978) - 10 g de solo com $20 \mathrm{~mL}$ da solução extratora DTPA-TEA, tamponado a $\mathrm{pH} 7,3$ foram agitados por 2 horas, em agitador horizontal (200 agitações por minuto). $\mathrm{O}$ extrato obtido foi filtrado em papel de filtro Whatman 42 e nele determinaram-se os micronutrientes $\mathrm{Cu}$, $\mathrm{Fe}, \mathrm{Mn}$ e $\mathrm{Zn}$ por espectrofotometria de absorção atômica (EAA).

e) AB-DTPA (bicarbonato de amônio-ácido dietileno triamino pentaacético) - a determinação do teor de molibdênio disponível foi realizada de acordo com a metodologia descrita por Soltanpour \& Workman (1979). A solução de AB-DTPA foi preparada diariamente com $1,97 \mathrm{~g}$ de DTPA ácido dissolvidos em $800 \mathrm{~mL}$ de água deionizada em balão volumétrico de $1 \mathrm{~L}$. Para ajudar na dissolução e previnir a efervescência, adicionouse $2 \mathrm{~mL}$ de $\mathrm{NH}_{4} \mathrm{OH}$ 1:1. Após ter dissolvido o DTPA, juntou-se 79,06 g de $\mathrm{NH}_{4} \mathrm{HCO}_{3}$ agitando-se cuidadosamente até dissolver. Ajustou-se o $\mathrm{pH}$ para 7,6 com $\mathrm{HCl}$ ou $\mathrm{NH}_{4} \mathrm{OH}$ e completou-se o volume para $1 \mathrm{~L}$ com água deionizada. Procedeu-se à extração agitando-se $10 \mathrm{~g}$ de TFSA com $20 \mathrm{~mL}$ da solução de AB-DTPA em frascos de $125 \mathrm{~mL}$ abertos por 15 minutos, em agitador horizontal (180 agitações por minuto). O extrato obtido foi filtrado em papel de filtro Whatman 42 . À uma alíquota de $5 \mathrm{~mL}$ do extrato adicionou-se cuidadosamente $0,5 \mathrm{~mL}$ de $\mathrm{HNO}_{3}$ concentrado e agitou-se por mais 15 minutos (120 agitações por minuto) para eliminar os carbonatos que poderiam preciptar, causando possíveis interferências durante as leituras no ICP-AES.

\subsection{Análise química do material vegetal}

As análises químicas da matéria seca da parte aérea do arroz, foram feitas segundo os métodos descritos por Malavolta et al. (1989):

a) Nitrogênio-N - digestão sulfúrica para determinação do $\mathrm{N}$ por semi-microKjeldahl na matéria seca da parte aérea do arroz. 
b) P, K, Ca, Mg, S, Cu, Fe, Mn, e $\mathbf{Z n}$ - obtenção do extrato por via úmida (digestão nítrico-perclórica). Cálcio, $\mathrm{Mg}, \mathrm{Cu}, \mathrm{Fe}, \mathrm{Mn}$ e $\mathrm{Zn}$ foram determinados por espectrofotometria de absorção atômica (EAA); o fósforo, por colorimetria do metavanadato; o potássio, por fotometria de chama de emissão e o enxofre, por turbidimetria do sulfato de bário.

c) Boro e molibdênio - digestão por via seca (incineração). O boro foi determinado por colorimetria da azometina $\mathrm{H}$ e o molibdênio por colorimetria do tiocianato.

\section{10 Análise estatística dos resultados}

As análises foram feitas de acordo com Pimentel Gomes (1985), com o auxílio do software SANEST (Zonta et al., 1987). A Tabela 2 mostra o esquema da análise da variância empregado nos experimentos. Realizaram-se ainda, análises de correlação e regressão linear simples dos teores e conteúdos de $\mathrm{Cu}, \mathrm{Fe}, \mathrm{Mn}$ e $\mathrm{Zn}$ na matéria seca da parte aérea do arroz e os seus teores nos solos, obtidos com as diferentes soluções extratoras. Todos os resultados foram analisados ao nível de $5 \%$ de probabilidade.

Tabela 2. Análise da variância de acordo com o esquema em parcelas subdivididas.

\begin{tabular}{lc}
\hline Causa da variação & G.L. \\
\hline Blocos (j) & $(\mathrm{j}-1)$ \\
Solos (i) & $(\mathrm{i}-1)$ \\
Resíduo (A) & $(\mathrm{j}-1)(\mathrm{i}-1)$ \\
\hline Parcelas & $(\mathrm{ij}-1)$ \\
\hline Tratamentos (k) & $(\mathrm{k}-1)$ \\
Solos x Tratamentos & $(\mathrm{i}-1)(\mathrm{k}-1)$ \\
Resíduo (B) & $\mathrm{i}(\mathrm{k}-1)(\mathrm{j}-1)$ \\
\hline Total & $(\mathrm{ikj})-1$ \\
\hline
\end{tabular}




\section{RESULTADOS E DISCUSSÃO}

\subsection{Solos}

Dada as poucas informações existentes sobre a fertilidade dos solos da Amazônia, realizou-se uma avaliação inicial das características fisicas, mineralógicas e químicas dos mesmos, a qual serviu de orientação na definição da adubação e dos tratamentos dos experimentos conduzidos. Pelos resultados da análise granulométrica (Tabela 3) verificou-se uma grande variação textural entre os solos estudados, considerando-se o teor de argila (62 a $865 \mathrm{~g} \mathrm{~kg}^{-1}$ ). A porosidade dos solos (Ps) variou de 46 a $64 \%$, sendo: LA-2 $>$ LA-1 $>$ PV $>$ GHP $>$ LH $>$ PA-2 $>$ LA-3 $>$ PA-1 $>$ P-1 $=$ P-2. Os dados da Tabela 3 ilustram a assertiva de que os solos argilosos possuem densidade do solo (Ds) menor e maior porosidade.

A composição mineralógica da fração argila das amostras dos diferentes latossolos, podzólicos e podzois apresentou semelhanças em termos qualitativos (Tabela 4), sendo, provavelmente, a caulinita o mineral predominante, geralmente acompanhada pela presença de gibbsita e de óxidos de ferro como ilmenita e goethita. Corroboram estes resultados os estudos mineralógicos realizados por Möller (1986) e Silva (1989) nos solos da região. Por outro lado, o $\mathrm{AL}$, de ocorrência comum nas planícies de inundação (várzeas), devido a diversidade de materiais litólicos de origem, apresentou também, na sua constituição mineralógica, a mica e a montmorilonita e na sua composição granulométrica predominou o silte (Tabelas 3 e 4). Vale ressaltar que os aluviais e os gleissolos correspondem a 6,12\% das terras da Amazônia Legal (Rodrigues, 1996) e apresentam grande potencial para culturas de ciclo curto como arroz e feijão. 
Tabela 3 - Resultados das análises fisicas das amostras dos solos estudados $(0-20 \mathrm{~cm})$.

\begin{tabular}{|c|c|c|c|c|c|c|c|c|c|c|}
\hline \multirow{3}{*}{ Solos } & \multicolumn{6}{|c|}{ Composição granulométrica $\left(\mathrm{g} \mathrm{kg}^{-1}\right)^{(1)}$} & \multirow{3}{*}{$\begin{array}{l}\text { Classe } \\
\text { textural }^{(2)}\end{array}$} & \multirow{3}{*}{$\mathbf{D} \mathbf{p}^{(3)}$} & \multirow{3}{*}{$\mathrm{Ds}^{(\mathfrak{4})}$} & \multirow{3}{*}{$\begin{array}{l}\mathbf{P s}^{(5)} \\
(\%)\end{array}$} \\
\hline & \multicolumn{2}{|c|}{ Argila } & \multicolumn{2}{|c|}{ Silte } & \multicolumn{2}{|c|}{ Areia } & & & & \\
\hline & Pipeta & Boyocus & Pipeta & Boyocus & Pipeta & Boyocus & & & & \\
\hline P-1 & 79 & 62 & 20 & 41 & 901 & 897 & arenosa & 2,63 & 1,42 & 46 \\
\hline P-2 & 95 & 20 & 4 & 41 & 901 & 939 & arenosa & 2,63 & 1,43 & 46 \\
\hline PA-1 & 136 & 184 & 92 & 20 & 772 & 796 & arenosa & 2,57 & 1,26 & 51 \\
\hline PA-2 & 187 & 204 & 64 & 20 & 749 & 776 & média & 2,54 & 1,14 & 55 \\
\hline PV & 513 & 667 & 202 & 40 & 285 & 293 & argilosa & 2,55 & 1,01 & 60 \\
\hline LA-1 & 734 & 820 & 185 & 40 & 81 & 140 & muito argilosa & 2,45 & 0,90 & 63 \\
\hline LA-2 & 711 & 865 & 192 & 41 & 97 & 94 & muito argilosa & 2,61 & 0,93 & 64 \\
\hline LA-3 & 211 & 242 & 77 & 40 & 712 & 717 & média & 2,60 & 1,20 & 54 \\
\hline LH & 439 & 560 & 257 & 100 & 304 & 340 & argilosa & 2,46 & 1,08 & 56 \\
\hline $\mathbf{A L}$ & 237 & 303 & 738 & 586 & 25 & 111 & siltosa & 2,43 & 0,99 & 59 \\
\hline
\end{tabular}

${ }^{(1)}$ Classes de Diâmetro (mm): areia $=2-0,05$; silte $=0,05-0,002 ;$ argila $=<0,002$

${ }^{(2)}$ Classe de Textura $\left(\mathrm{g} \mathrm{kg}^{-1}\right):<140$ de argila e $>700$ de areia $=$ arenosa; $<350$ de argila, $<500$ de silte e $>150$ de areia $=$ média; 350 a $590=$ argilosa $; 2600=$ muito argilosa; $>500$ de silte, $<350$ de argila e $<150$ de areia $=$ siltosa

${ }^{(3)}$ Densidade das partículas

${ }^{(4)}$ Densidade do solo

${ }^{(5)}$ Porosidade do solo

Constam na Tabela 5 os teores totais dos elementos nas dez amostras de solo utilizadas nos experimentos. De modo geral, as maiores "reservas" de nutrientes foram observadas para os solos AL e $\mathrm{LH}$ e as menores, para os solos podzois. No caso específico dos micronutrientes, verificou-se teores totais mais elevados nas amostras de solo de textura mais fina (Tabelas 3 e 5). Entre os fatores que influenciam os teores totais dos micronutrientes no solo, Sillanpãã (1972) destaca a textura e o teor de matéria orgânica dos solos. Segundo este autor, os solos de textura mais fina (argilosos e siltosos) derivam de minerais de fácil decomposição que são as principais fontes de micronutrientes, enquanto os solos de textura grosseira (arenosos) derivam de minerais mais resistentes e pobres em micronutrientes.

O teor total de boro nas amostras de solo (Tabela 5) variou de 1,79 (P-1) a $30 \mathrm{mg} \mathrm{kg}^{-1}(\mathrm{LH})$. Os teores totais médios $\left(16,5 \mathrm{mg} \mathrm{kg}^{-1}\right)$ obtidos dos solos LH, LA-1, 
LA-2, PV, e AL ficaram abaixo daqueles encontrados por Brasil Sobrinho (1965) em solos do Estado de São Paulo (31,3 a 54,0 $\mathrm{mg} \mathrm{kg}^{-1}$ ) e por Vanderlei et al.(1988) em solos do Estado de Minas Gerais (29,0 a $\left.38,0 \mathrm{mg} \mathrm{kg}^{-1}\right)$. O cobre apresentou comportamento semelhante ao boro, sendo que seus teores totais variaram de 3,35 (P-1) a $28,31 \mathrm{mg} \mathrm{kg}^{-1}$ (AL). Estes resultados estão de acordo com aqueles encontrados por Singh (1984b) em seus estudos de disponibilidade de micronutrientes em classes dominantes de solos do trópico úmido brasileiro.

Tabela 4. Composição mineralógica qualitativa das amostras dos solos estudados $(0-20 \mathrm{~cm})^{1}$

\begin{tabular}{|c|c|c|c|}
\hline Solos & \multicolumn{3}{|c|}{ Composição Mineralógica } \\
\hline P-1 & $\begin{array}{l}\text { Silte } \\
\text { Feldspato } \\
\text { Pirofilita }\end{array}$ & $\begin{array}{l}\text { Argila } \\
\text { Caulinita } \\
\text { Gibbsita }\end{array}$ & $\begin{array}{c}\text { Concentração dos óxidos de Ferro } \\
\text { Ilmenita } \\
\text { Goethita }\end{array}$ \\
\hline $\mathrm{P}-2$ & $\begin{array}{l}\text { Feldspato } \\
\text { Pirofilita }\end{array}$ & Caulinita & $\frac{\text { Goethita }}{\text { Gin }}$ \\
\hline PA-1 & $\begin{array}{l}\text { Feldspato } \\
\text { Pirofilita }\end{array}$ & $\begin{array}{l}\text { Caulinita } \\
\text { Gibbsita }\end{array}$ & $\begin{array}{l}\text { Ilmenita } \\
\text { Magnetita }\end{array}$ \\
\hline PA-2 & $\begin{array}{l}\text { Feldspato } \\
\text { Pirofilita }\end{array}$ & $\begin{array}{l}\text { Caulinita } \\
\text { Gibbsita }\end{array}$ & Goethita \\
\hline PV & $\begin{array}{l}\text { Feldspato } \\
\text { Pirofilita }\end{array}$ & $\begin{array}{l}\text { Caulinita } \\
\text { Gibbsita }\end{array}$ & $\begin{array}{l}\text { Goethita } \\
\text { Ilmenita }\end{array}$ \\
\hline LA-1 & $\begin{array}{l}\text { Feldspato } \\
\text { Pirofilita }\end{array}$ & $\begin{array}{l}\text { Caulinita } \\
\text { Gibbsita }\end{array}$ & Ilmenita \\
\hline LA-2 & Feldspato & $\begin{array}{l}\text { Caulinita } \\
\text { Gibbsita }\end{array}$ & $\begin{array}{l}\text { Ilmenita } \\
\text { Goethita } \\
\text { Magnetita }\end{array}$ \\
\hline LA-3 & $\begin{array}{l}\text { Feldspato } \\
\text { Pirofilita }\end{array}$ & $\begin{array}{l}\text { Caulinita } \\
\text { Quartzo }\end{array}$ & $\begin{array}{l}\text { Ilmenita } \\
\text { Goethita }\end{array}$ \\
\hline LH & Feldspato & $\begin{array}{l}\text { Caulinita } \\
\text { Gibbsita }\end{array}$ & $\begin{array}{l}\text { Goethita } \\
\text { Ilmenita }\end{array}$ \\
\hline AL & $\begin{array}{l}\text { Feldspato } \\
\text { Plagioclásio } \\
\text { Pirofilita }\end{array}$ & $\begin{array}{l}\text { Caulinita } \\
\text { Mica } \\
\text { Montmorilonita } \\
\end{array}$ & $\begin{array}{l}\text { Ilmenita } \\
\text { Goethita }\end{array}$ \\
\hline
\end{tabular}

Os teores totais de ferro obtidos (Tabela 5) estão dentro da faixa de variação mais comum para a maioria dos solos $(0,5$ a $10 \%)$, exceto para os podzois que apresentaram valores muito baixos $(0,06$ a $0,09 \%)$. 
O conteúdo total de manganês, nas amostras dos solos estudadas, variou de 16,0 a $1.244,8 \mathrm{mg} \mathrm{kg}^{-1}$ (Tabela 5). Estes valores estão dentro da faixa encontrada (15 a $3.467 \mathrm{mg} \mathrm{kg}^{-1}$ ) por Singh (1984a) nas mesmas classes de solo da região Amazônica e por Santana \& Igue (1972) em solos da região cacaueira da Bahia. Por outro lado, os teores totais de zinco obtidos foram geralmente maiores do que aqueles encontrados por Sing \&Möller (1984) nas mesmas classes de solos da região. Os valores obtidos no LH $\left(198,4 \mathrm{mg} \mathrm{kg}^{-1}\right)$ e no $\mathrm{AL}\left(105,3 \mathrm{mg} \mathrm{kg}^{-1}\right)$ estão dentro das concentrações totais consideradas excessivas para este elemento do ponto de vista de fitotoxicidade (Malavolta, 1994).

Tabela 5. Teores totais nas amostras dos solos usados nos experimentos, na camada de $0.20 \mathrm{~cm}$ (média de duas repetições).

\begin{tabular}{|c|c|c|c|c|c|c|c|c|c|c|}
\hline \multirow{2}{*}{ Elementos } & \multicolumn{10}{|c|}{ Solos } \\
\hline & P-1 & P-2 & PA-1 & PA-2 & PV & LA-1 & LA-2 & LA-3 & LH & $\mathrm{AL}$ \\
\hline $\mathrm{P}\left(\mathrm{mg} \mathrm{kg}^{-1}\right)$ & 86,9 & 31,4 & 167,1 & 229,7 & 896,3 & 529,3 & 609,3 & 237,9 & 1198,4 & 846,6 \\
\hline $\mathrm{K}\left(\mathrm{mmnol}_{\mathrm{c}} \mathrm{kg}^{-\mathrm{l}}\right)$ & 2,1 & 1,5 & 2,2 & 1,4 & 10,3 & 2,7 & 3,1 & 3,6 & 20,4 & 75,7 \\
\hline $\mathrm{Na}\left(\right.$ mmolc $\left._{\mathrm{cg}} \mathrm{kg}^{-1}\right)$ & 6,5 & 5,7 & 6,5 & 5,7 & 8,0 & 6,5 & 8,4 & 6,1 & 20,0 & 44,3 \\
\hline $\mathrm{Ca}\left(\mathrm{mmol}_{\mathrm{c}} \mathrm{kg}^{-\mathrm{l}}\right)$ & 10,1 & 7,0 & 8,5 & 6,1 & 6,6 & 3,6 & 3,7 & 16,9 & 89,8 & 273,8 \\
\hline $\mathrm{Mg}\left(\mathrm{mmol}_{\mathrm{c}} \mathrm{kg}^{-1}\right)$ & 83,1 & 57,8 & 70,1 & 50,0 & 54,0 & 29,3 & 30,8 & 138,7 & 738,8 & 2253,3 \\
\hline $\mathrm{Al}\left(\mathrm{mmol}_{\mathrm{c}} \mathrm{kg}^{-1}\right)$ & 1055,1 & 276,6 & 2986,2 & 4051,6 & 10694,6 & 11682,6 & 12362,8 & 3763,8 & 8949,6 & 4405,1 \\
\hline $\mathrm{B}\left(\mathrm{mg} \mathrm{kg} \mathrm{g}^{-1}\right)$ & 1,8 & 4,8 & 2,4 & 3,0 & 16,6 & 10,3 & 14,9 & 3,1 & 30,0 & 10,7 \\
\hline $\mathrm{Cu}\left(\mathrm{mg} \mathrm{kg}^{-1}\right)$ & 3,4 & 6,2 & 3,9 & 4,2 & 14,3 & 12,8 & 10,8 & 4,7 & 23,7 & 28,3 \\
\hline $\mathrm{Fe}\left(\mathrm{mg} \mathrm{kg}^{-1}\right)$ & 923,6 & 594,8 & 3129,7 & 7157,6 & 69022,5 & 25713,1 & 56157,5 & 5636,3 & 59845,0 & 36244,9 \\
\hline $\operatorname{Mn}\left(\mathrm{mg} \mathrm{kg}^{-1}\right)$ & 16,0 & 27,1 & 29,4 & 55,5 & 651,7 & 67,9 & 139,5 & 23,9 & 1244,8 & 548,4 \\
\hline $\mathrm{Zn}\left(\mathrm{mg} \mathrm{kg} \mathrm{g}^{-1}\right)$ & 9,5 & 7,6 & 10,2 & 11,1 & 67,7 & 20,5 & 24,0 & 10,0 & 198,4 & 105,3 \\
\hline
\end{tabular}

Os resultados da análise química das amostras dos solos utilizados nos experimentos, apresentados na Tabela 6, indicam a natureza predominantemente ácida dos solos da Amazônia, bem como seu caráter álico e/ou distrófico e sua baixa fertilidade química, com teores de fósforo, cálcio, potássio e magnésio deficientes. Exceção deve ser feita aos solos aluviais (representativo das áreas de várzeas da Amazônia) e LH (de pequena ocorrência, conhecido, regionalmente, como "Terra Preta de Índio", segundo 
Vieira (1988)) que possuem teores disponíveis de $\mathrm{P}, \mathrm{Ca}$ e $\mathrm{Mg}$ mais elevados e baixa saturação por alumínio, apresentando portanto, uma fertilidade natural mais adequada ao desenvolvimento das culturas.

Com relação a disponibilidade dos micronutrientes, chama a atenção os altos teores de cobre, manganês e zinco encontrados nos solos AL e LH, justificando que apenas metade da dose utilizada nos tratamentos (Tabela 1) fosse aplicada. De acordo com Raij et al. (1996), os teores destes micronutrientes encontrados nos demais solos são classificados como baixos (Tabela 4).

\section{2 Desenvolvimento das plantas e produção de matéria seca vegetal}

Sintomas visuais de deficiências foram observados apenas para os tratamentos menos ferro e menos manganês, principalmente nas amostras dos solos podzois. No geral, a diferença no desenvolvimento das plantas só foi visivel com relação à testemunha absoluta, que para todos os solos apresentou menor crescimento. Por outro lado, as amostras dos solos $\mathrm{AL}, \mathrm{PV}, \mathrm{LH}, \mathrm{LA}-1$ e LA-2 propiciaram um melhor desenvolvimento das plantas. Nos podzois, devido às suas características fisicas e químicas (Tabelas 3,5 e 6), as plantas apresentaram germinação irregular e desenvolvimento inferior aos demais solos.

As análises das variâncias dos dados de produção de matéria seca da parte aérea, da raiz e total obtidos no primeiro (Tabela 7), no segundo (Tabela 8) e no terceiro cultivo (Tabela 9) mostraram diferenças significativas $(\mathrm{P}<0.05)$ entre os solos, os tratamentos e na interação solo $\mathrm{x}$ tratamento. Observou-se que a aplicação dos nutrientes, independente da omissão de um deles, influenciou de maneira significativa o incremento do peso da matéria seca. Consequentemente, a produção de matéria seca foi estatisticamente inferior para todos os solos na ausência da aplicação dos nutrientes (testemunha absoluta). O mesmo comportamento foi observado para o segundo e terceiro cultivo (Tabelas 8 e 9). Estes resultados confirmam a baixa capacidade destes solos em fornecer os nutrientes necessários ao bom desenvolvimento das plantas. Por outro lado, as condições de "solos não cultivados" dos solos utilizados neste estudo, associado a 
Tabela 6. Características químicas das amostras dos solos estudados $(0-20 \mathrm{~cm})$.

\begin{tabular}{|c|c|c|c|c|c|c|c|c|c|c|}
\hline \multirow{2}{*}{ Características } & \multicolumn{10}{|c|}{ Solos } \\
\hline & P-1 & P-2 & PA-1 & PA-2 & PV & LA-1 & LA-2 & LA-3 & LH & $\mathrm{AL}$ \\
\hline $\mathrm{pH} \mathrm{em} \mathrm{CaCl}_{2}(1: 2,5)$ & 4,09 & 2,89 & 3,59 & 3,49 & 3,40 & 3,50 & 3,89 & 4,19 & 4,60 & 4,19 \\
\hline pH em água (1:2,5) & 4,29 & 3,64 & 3,90 & 3,95 & 3,86 & 3,97 & 4,02 & 4,83 & 5,20 & 4,59 \\
\hline $\mathrm{pHem} \mathrm{KCl}(1: 2,5)$ & 3,91 & 2,52 & 3,33 & 3,31 & 3,39 & 3,46 & 3,62 & 3,91 & 4,38 & 3,63 \\
\hline$\Delta \mathrm{pH}$ & $-0,38$ & $-1,12$ & $-0,57$ & $\bullet, 64$ & $-0,47$ & $-0,51$ & $-0,40$ & $-0,92$ & $-8,82$ & $-0,96$ \\
\hline $\mathrm{MO} .\left(\mathrm{g} \mathrm{dm}^{-3}\right)^{(1)}$ & 19,0 & 25 & 32 & 34 & 37 & 40 & 27 & 19 & 44 & 30 \\
\hline P-resina $\left(\mathrm{mg} \mathrm{dm}^{-3}\right)$ & 3 & 4 & 5 & 6 & 6 & 4 & 3 & 5 & 25 & 18 \\
\hline $\mathrm{SSO}_{4}^{2-}\left(\mathrm{mg} \mathrm{dm}^{-3}\right)^{(2)}$ & 31,1 & 18,9 & 36,4 & 19,7 & 50,5 & 58,0 & 80,8 & 14,9 & 34,2 & 26,2 \\
\hline $\mathrm{Na}^{+}-$Mehlich $\mathrm{l}\left(\mathrm{mg} \mathrm{dm}^{-3}\right)$ & 2,3 & 4,6 & 6,9 & 4,6 & 4,6 & 9,2 & 6,9 & 2,3 & 4,6 & 322 \\
\hline $\mathrm{K}^{+}$-resina $\left(\mathrm{mmol}_{c} \mathrm{dm}^{-3}\right)^{*}$ & 0,5 & 0,2 & 0,8 & 0,5 & 0,9 & 0,8 & 02 & 1,6 & 0,9 & 1,6 \\
\hline $\mathrm{Ca}^{2+}-\mathrm{resina}\left(\mathrm{mmol}_{\mathrm{c}} \mathrm{dm}^{-3}\right)^{*}$ & 3,0 & 1,0 & 1,0 & 1,0 & 3,0 & 2,0 & 3,0 & 23,0 & 43,0 & 101,0 \\
\hline $\mathrm{Mg}^{2+}$-resina $\left(\mathrm{mmolc}_{\mathrm{cm}} \mathrm{dm}^{-3}\right)^{*}$ & 2,0 & 1,0 & 1,0 & 1,0 & 2,0 & 1,0 & 2,0 & 6,0 & 21,0 & 21,0 \\
\hline $\mathrm{Al}^{3+}-\mathrm{KCl} \mathrm{IN}\left(\mathrm{mmol}_{\mathrm{c}} \mathrm{dm}^{-3}\right)$ & 11 & 7 & 17 & 18 & 23 & 24 & 17 & 6 & 2 & 12 \\
\hline $\mathrm{H}^{+}+\mathrm{Al}^{3+}\left(\mathrm{mmol}_{\mathrm{c}} \mathrm{dm}^{-3}\right)^{(3)}$ & 38,0 & 58,0 & 98,0 & 88,0 & 15,0 & 12,1 & 10,9 & 38,0 & 98,0 & 72,0 \\
\hline $\mathrm{SB}\left(\mathrm{mmol}_{\mathrm{c}} \mathrm{dm}^{-3}\right)^{(4)}$ & 5,5 & 2,2 & 2,8 & 2,5 & 5,9 & 3,8 & 5,2 & 30,6 & 64,9 & 123,6 \\
\hline 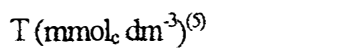 & 43,5 & 602 & 100,8 & 90,5 & 155,9 & 124,8 & 114,2 & 68,6 & 162,9 & 195,6 \\
\hline $\mathrm{V}(\%)^{(6)}$ & 14 & 3 & 3 & 3 & 4 & 3 & 4 & 45 & 40 & 63 \\
\hline $\mathrm{m}(\%)^{(1)}$ & 65 & 78 & 85 & 86 & 79 & 86 & 77 & 16 & 3 & 9 \\
\hline $\mathrm{SiO}_{2}\left(\mathrm{~g} \mathrm{~kg}^{-1}\right)^{(8)}$ & 28,0 & 1,9 & 56,0 & 8,1 & 23,8 & 35,3 & 32,8 & 9,1 & 18,5 & 16,6 \\
\hline $\mathrm{Al}_{2} \mathrm{O}_{3}\left(\mathrm{~g} \mathrm{~kg}^{-1}\right)^{(8)}$ & 68,3 & 2,6 & 100,0 & 61,3 & 198,2 & 289,6 & 276,3 & 60,7 & 184,4 & 80,7 \\
\hline $\mathrm{Fe}_{2} \mathrm{O}_{3}\left(\mathrm{~g} \mathrm{~kg}^{-1}\right)^{(8)}$ & 0,5 & 0,2 & 1,4 & 4,0 & 52,8 & 13,4 & 43,8 & 3,4 & 48,6 & 27,0 \\
\hline $\mathrm{TiO}_{2}\left(\mathrm{~g} \mathrm{~kg}^{-1}\right)^{(8)}$ & 2,6 & 1,6 & 3,6 & 7,5 & 33,0 & 24,4 & 22,4 & 4,2 & 30,5 & 10,9 \\
\hline $\mathrm{MnO}\left(\mathrm{g} \mathrm{kg}^{-1}\right)^{(8)}$ & - & - & - & - & 0,5 & 0,1 & 0,1 & - & 12 & 0,6 \\
\hline $\mathrm{BCaCl}_{2} 0,1 \%\left(\mathrm{mg} \mathrm{dm}^{-3}\right)$ & 0,44 & 0,44 & $\bullet, 64$ & 0,47 & 0,64 & 0,89 & 0,35 & 0,36 & 0,90 & 0,33 \\
\hline Cu-DTPA-TEA $\left(\mathrm{mg} \mathrm{dm}^{-3}\right)$ & 0,08 & 0,12 & 0,10 & 0,14 & 0,20 & 0,16 & 0,28 & 0,26 & 1,14 & 4,72 \\
\hline Fe-DTPA-TEA (mg dm${ }^{-3}$ ) & 14 & 17 & 188 & 402 & 272 & 157 & 49 & 87 & 61 & 386 \\
\hline Mn-DTPA-TEA (mg dm${ }^{-3}$ ) & 0,96 & 1,46 & 1,06 & 1,28 & 9,18 & 2,40 & 5,50 & 6,62 & 96,90 & 87,50 \\
\hline Zn-DTPA-TEA $\left(\mathrm{mg} \mathrm{dm}^{-3}\right)$ & 0,3 & 0,2 & 0,4 & 0,4 & 0,6 & 0,6 & 0,4 & 0,6 & 3,3 & 4,4 \\
\hline $\begin{array}{l}\text { (1) Método colorimétrico } \\
\text { (2) Extrator } \mathrm{NH}_{4} \mathrm{OAc} 0,5 \\
\text { (3) Acidez potencial - sol } \\
\text { (4) Soma de bases trocáve } \\
\text { (5) Capacidade de troca d } \\
\text { (6) Saturação de bases (S } \\
\text { (7) Saturação de alumínio } \\
\text { (8) Ataque sulfúrico - ext }\end{array}$ & $\begin{array}{l}\text { gio \& } \\
\text { em H } \\
\text { ampão } \\
\text { dos *) } \\
\text { ons (SB } \\
00) \\
+\left(\mathrm{SB}_{+}\right. \\
\mathrm{H}_{2} \mathrm{SO}_{4}\end{array}$ & $\begin{array}{l}\text { ij, } 1979 \\
\text { Ac } 0,25 \text { I } \\
\text { IP (Raij } \\
\left.+\mathrm{Al}^{3+}\right) \\
\\
+100]\end{array}$ & $\begin{array}{l}L^{-1} \\
\text { al., }\end{array}$ & & & & & & & \\
\hline
\end{tabular}

teores de matéria orgânica adequados(19 a $\left.44 \mathrm{~g} \mathrm{dm}^{-3}\right)$ explica, em parte, as poucas diferenças observadas entre os solos, devido ao efeito dos tratamentos aplicados sobre a produção de matéria seca, durante os três cultivos. Assim, observou-se que as produções 
médias de matéria seca total, independente do efeito dos tratamentos, variaram de acordo com a fertilidade dos solos, sendo: AL $>$ LA-1 $>$ PV $>$ LA-2 $>$ LH $>$ PA-2 $>$ LA-3 $>$ PA- $1>$ P $1>\mathrm{P}-2$ no primeiro cultivo; $\mathrm{AL}>\mathrm{LA}-\mathrm{l}>\mathrm{PV}>\mathrm{LH}>\mathrm{LA}-2>\mathrm{PA}-2>\mathrm{PA}-1>\mathrm{LA}-3>\mathrm{P}-1>\mathrm{P}-2$ no segundo cultivo e AL $>$ LA-2 $>$ LA-1 $>$ LH $>$ PV $>$ PA-2 $>$ PA- $1>$ LA-3 $>$ P-1 $>$ P-2 no terceiro cultivo.

As diferenças entre tratamentos com omissão de um dos micronutrientes durante os três cultivos, só foi mais nítida no solo P-2, onde o tratamento com omissão de ferro reduziu signicativamente a produção de matéria seca da parte aérea (Tabelas 7, 8 e 9). Loué (1993) assinala que de todos os cereais, o arroz é o mais sensível à deficiência de ferro. Dada as condições ácidas dos solos brasileiros, a carência de ferro no arroz não tem sido descrita no País, mas segundo Malavolta (1983), ela pode ser encontrada em solos arenosos pobres em ferro, ácidos e quando se faz aplicações pesadas de calcário ou de fósforo. Com base nesses pressupostos e nos baixos teores totais e disponíveis de ferro deste solo (Tabelas 3 e 5), associado às adubações de manutenção com $\mathrm{P}$ e Ca, estes resultados podem ser explicados.

O terceiro cultivo apresentou, comparativamente, as menores produções de matéria seca para todos os parâmetros avaliados (Tabelas 7, 8 e 9). Tal fato pode estar relacionado à competitividade devida ao aumento do número de plantas por vaso e a diminuição do efeito residual dos micronutrientes.

\section{3 Análise química do material vegetal}

Devido a pequena quantidade de matéria seca produzida pelo tratamento testemunha no solo P-1 (Tabela 7) do primeiro cultivo, não foi possível realizar a análise química do material vegetal, motivo pelo qual optou-se por exclui-lo das análises estatísticas relativas aos teores e conteúdos de nutrientes na matéria seca da parte aérea do arroz. No segundo e no terceiro cultivo, a produção de matéria seca, embora pequena e irregular, foi suficiente e as análises foram realizadas.

Segundo Malavolta (1980) o teor de um elemento na planta pode ser influenciado pelo nível de outros elementos no meio de crescimento, podendo haver 
inibições e sinergismos. Assim, o autor recomenda a análise de todos os nutrientes, mesmo que o interesse direto não seja por todos. Partindo-se dessa premissa, uma adubação de manutenção com macronutrientes foi realizada a cada cultivo.

\subsubsection{Macronutrientes}

Os teores totais e o conteúdo de nitrogênio em função dos tratamentos aplicados nos diferentes solos são apresentados na Tabela 10 para o primeiro cultivo, na Tabela 11 para o segundo cultivo e na Tabela 12 para o terceiro cultivo. De modo geral e para todos os cultivos, os teores de nitrogênio observados na matéria seca da parte aérea das plantas de arroz estão abaixo da faixa normal de concentração (Barbosa Filho, 1987; Malavolta et al., 1997). É necessário, porém, ter em mente que varią̧ões na composição mineral podem ser esperadas em função do cultivo e da idade de amostragem. Para todos os tratamentos, durante os três cultivos, encontraram-se teores de $\mathrm{N}$ na matéria seca da parte aérea (MSPA) das plantas de arroz cultivadas no solo AL significativamente inferiores aos demais solos. Para todos os solos a ausência da aplicação de nitrogênio (testemunha absoluta) implicou em conteúdos de $\mathrm{N}$ significativamente menores.

Mesmo com a aplicação de $200 \mathrm{mg} \mathrm{dm}^{-3}$ de P (Tabela 1), os teores obtidos desse elemento na matéria seca da parte aérea do arroz nos solos P-1, PA-1, PV, LA-1, LA-2, P-2, PA-2 e LA-3 (Tabelas 13, 14 e 15) ficaram apenas dentro da faixa considerada crítica por Barbosa Filho (1987). Esses resultados refletem a baixa fertilidade natural dos solos, principalmente a baixa disponibilidade de fósforo e a alta capacidade de adsorção dos mesmos. Em solos mais férteis, como o AL e LH (Tabela 6), optou-se pela aplicação de metade da dose da adubação fosfatada (Tabela 1). Entretanto, as plantas de arroz cultivadas nesses solos, apresentaram teores de fósforo na matéria seca da parte aérea significativamente inferiores em relação aos demais solos, durante os três cultivos. Por outro lado, corroborando a assertiva do critério adotado, na ausência da aplicação desse nutriente, os teores e conteúdos do mesmo na matéria seca da parte aérea ficaram entre os maiores observados (Tabelas 13,14 e 15). 
Os teores de potássio no primeiro (Tabela 16) e no segundo cultivo (Tabela 17) ficaram abaixo da faixa normal de concentração (Barbosa Filho, 1987), exceto para o arroz cultivado no solo AL, no qual, encontrou-se o dobro do teor e do conteúdo de potássio observados para os demais solos do primeiro cultivo. Comparativamente, a análise inicial dos solos indicou teores totais e disponiveis elevados nesses solos (Tabelas 5 e 6). Assim, mesmo na ausência da aplicação desse nutriente (testemunha absoluta) observaram-se teores adequados.

Os teores de cálcio no primeiro cultivo, independente dos tratamentos aplicados, ficaram dentro da faixa normal de concentração proposta por Barbosa Filho (1987), e abaixo daquela considerada adequada por Malavolta et al. (1997). No segundo cultivo, os teores de cálcio na MSPA diminuíram acentuadamente, em consequência da diminuição do efeito da calagem e da não aplicação de cálcio através da adubação fosfatada $\left(\mathrm{NH}_{4} \mathrm{H}_{2} \mathrm{PO}_{4}\right)$. No terceiro cultivo, com a utilização de $\mathrm{Ca}\left(\mathrm{H}_{2} \mathrm{PO}_{4}\right)_{2} \cdot \mathrm{H}_{2} \mathrm{O}$ como fonte de fósforo, os teores de Ca na MSPA do arroz atingiram os níveis considerados adequados por Malavolta et al. (1997).

O efeito residual do magnésio aplicado na calagem, elevando significativamente os teores e os conteúdos do elemento na MSPA do arroz, foi observado até o segundo cultivo (Tabelas 22 e 23). No terceiro cultivo (Tabela 24), apenas os solos LH, AL, PV, LA-1 e LA-2 mantiveram níveis adequados de $\mathrm{Mg}$ na MSPA (Barbosa Filho, 1987). Nos solos de textura arenosa à média (P-1, P-2, PA-1, PA-2 e LA-3), os teores e conteúdos desse elemento diminuíram acentuadamente entre o primeiro e o terceiro cultivo (Tabelas 22,23 e 24), confirmando a baixa capacidade de retenção de cátions desses solos, condicionada praticamente à matéria orgânica.

Os teores de enxofre na MSPA do arroz atingiram concentração adequada durante os três cultivos em todos os solos, sendo que nos solos P-1, P-2, PA-1, PA-2, $\mathrm{LH}, \mathrm{AL}$ e LA-3 foram também estatisticamente superiores à testemunha absoluta. Os teores e conteúdos médios desse elemento na MSPA do segundo e terceiro cultivo, apresentaram diferenças estatísticas entre os tratamentos na seguinte ordem: completo>omissão de Mo>testemunha absoluta. 


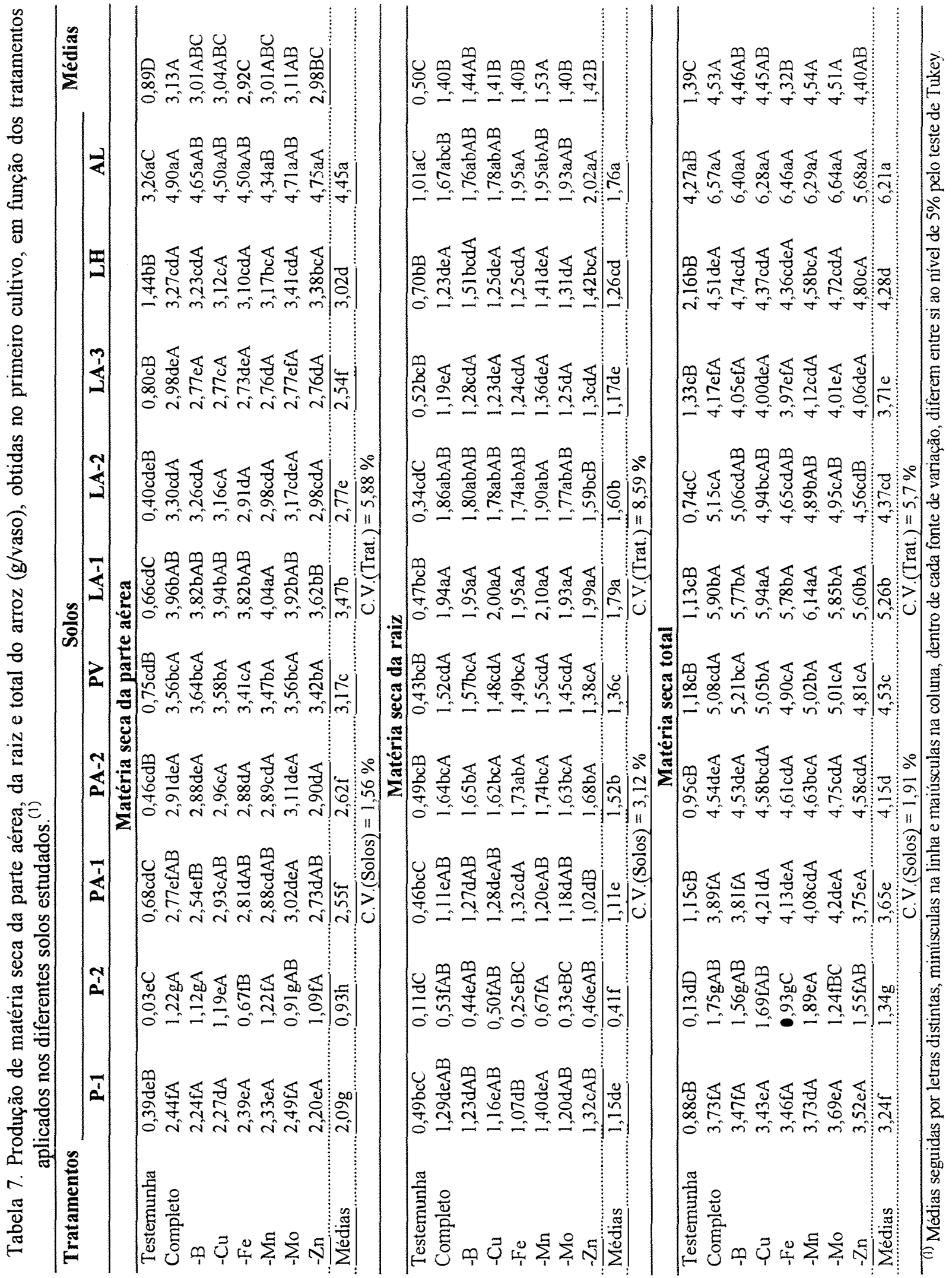




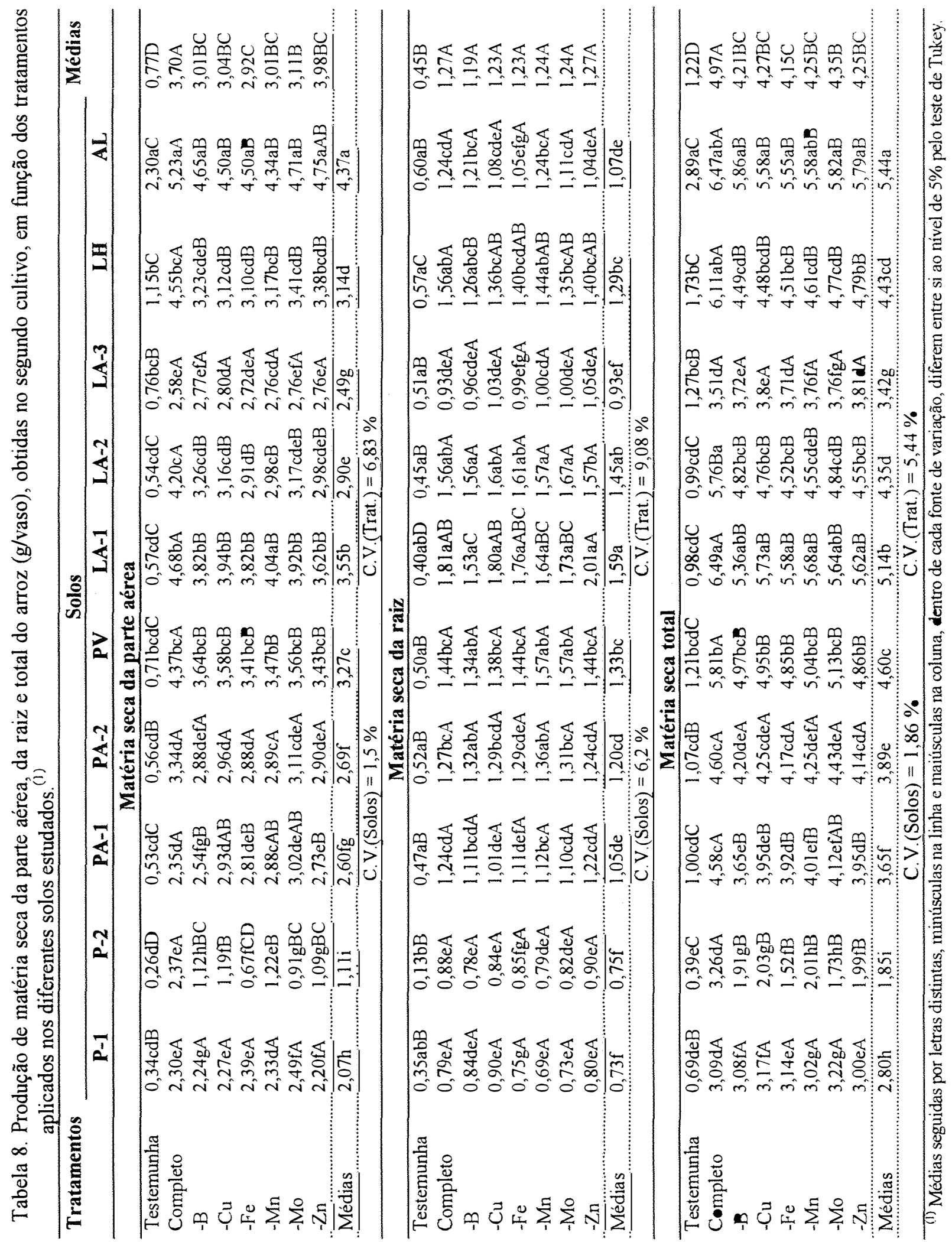




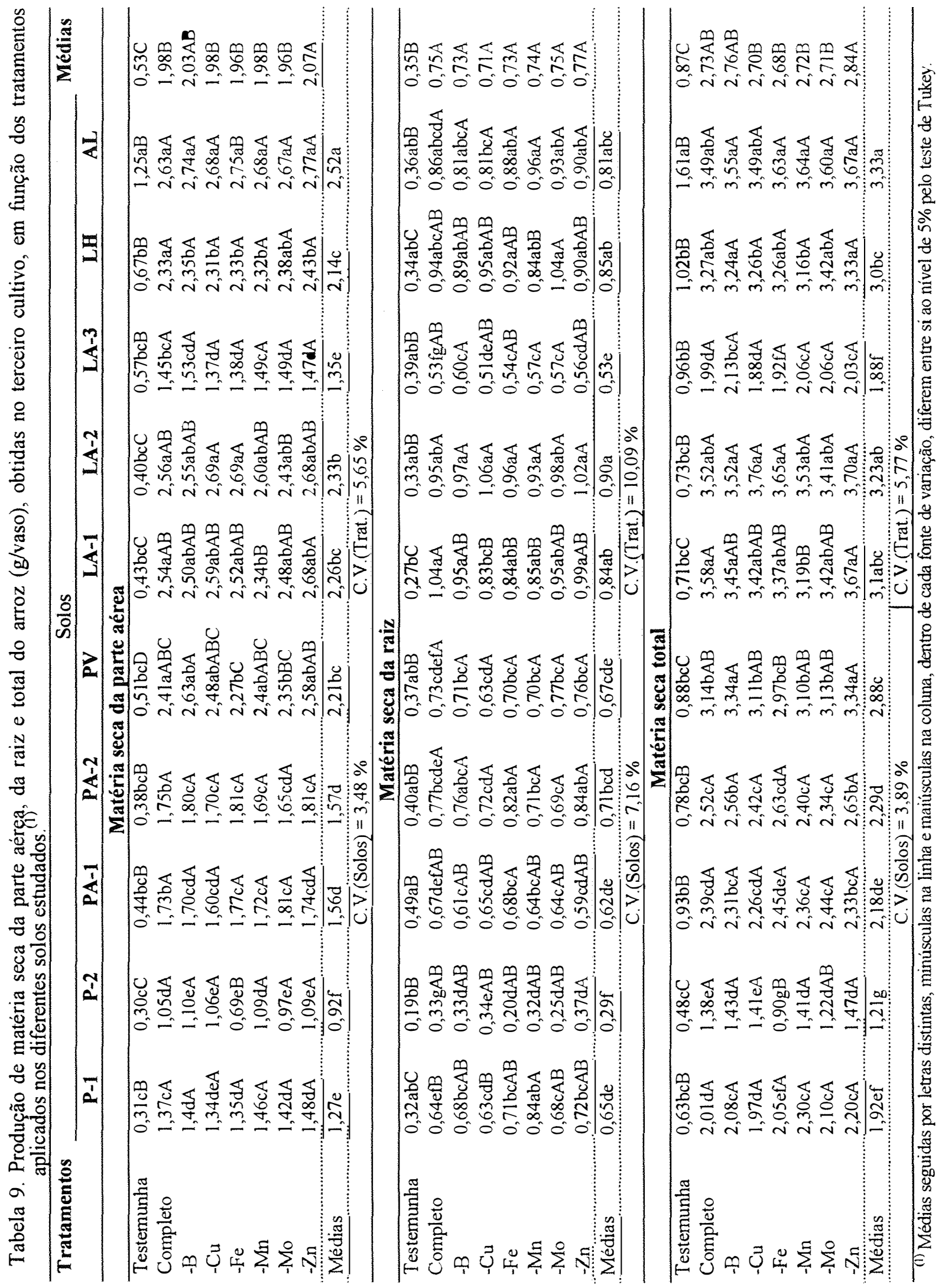




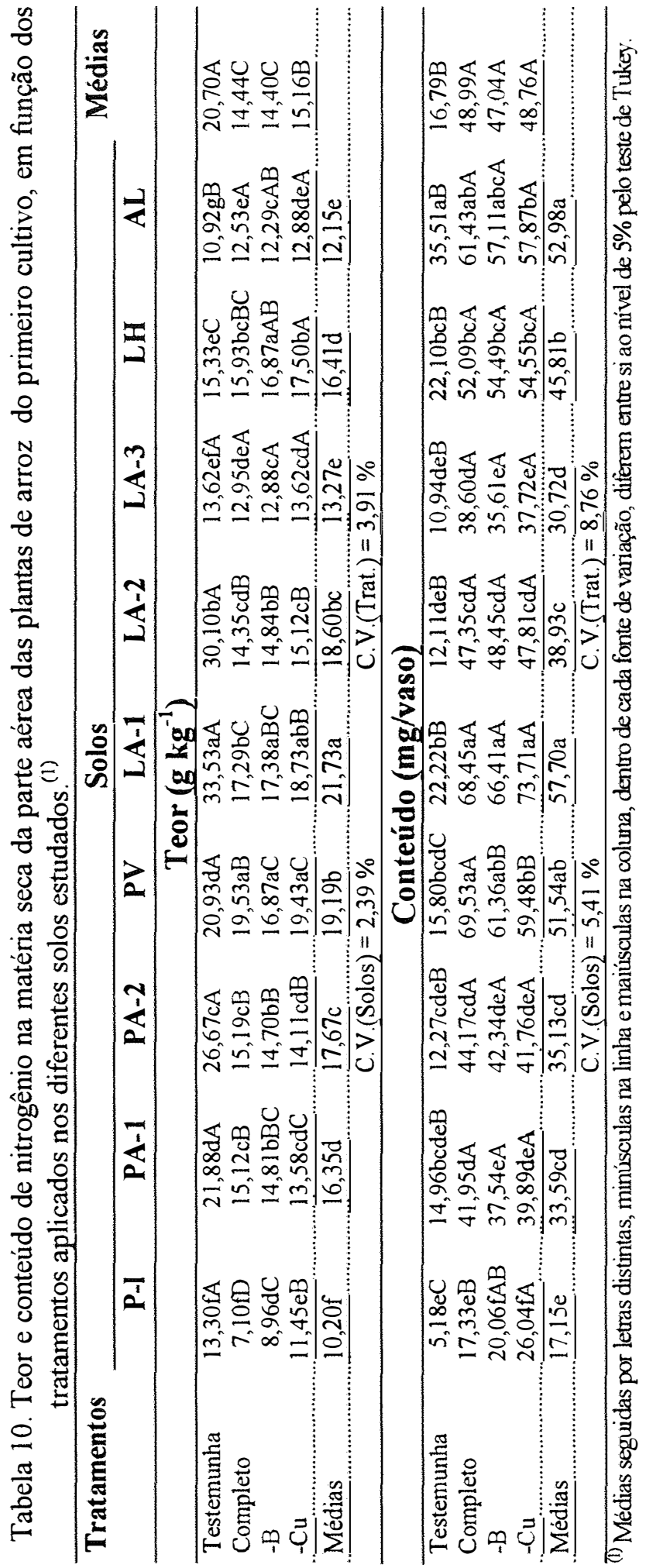




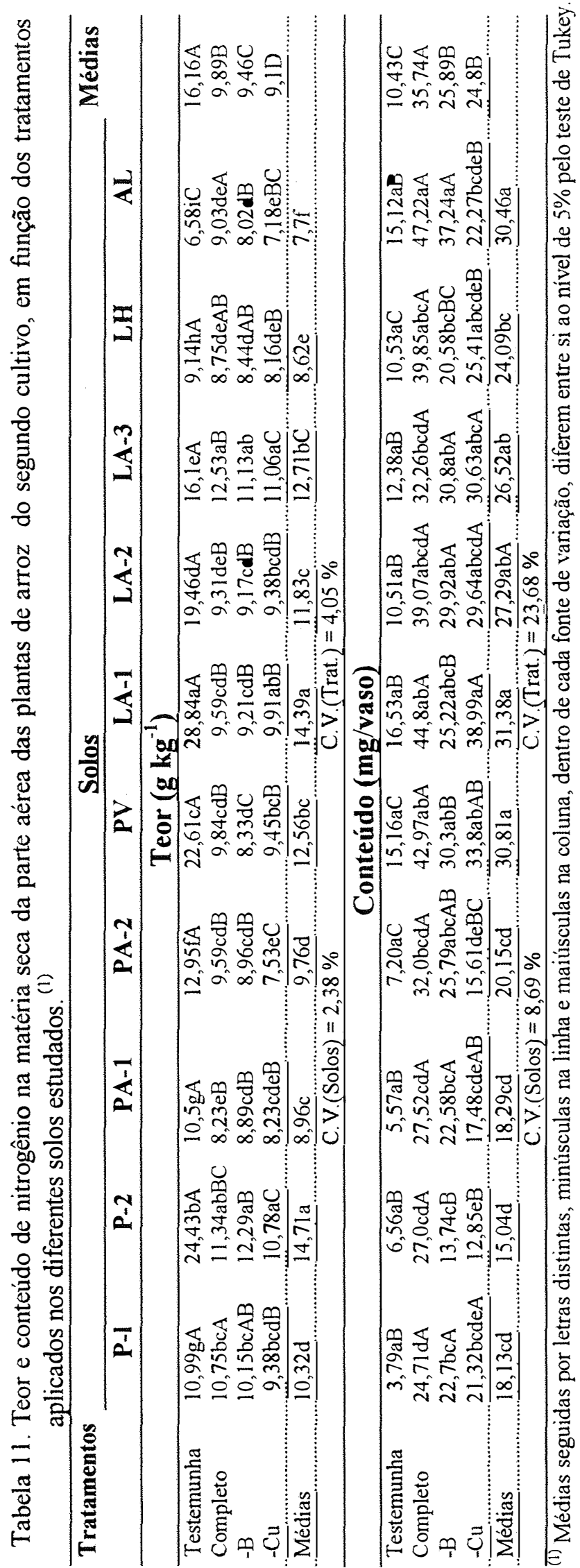




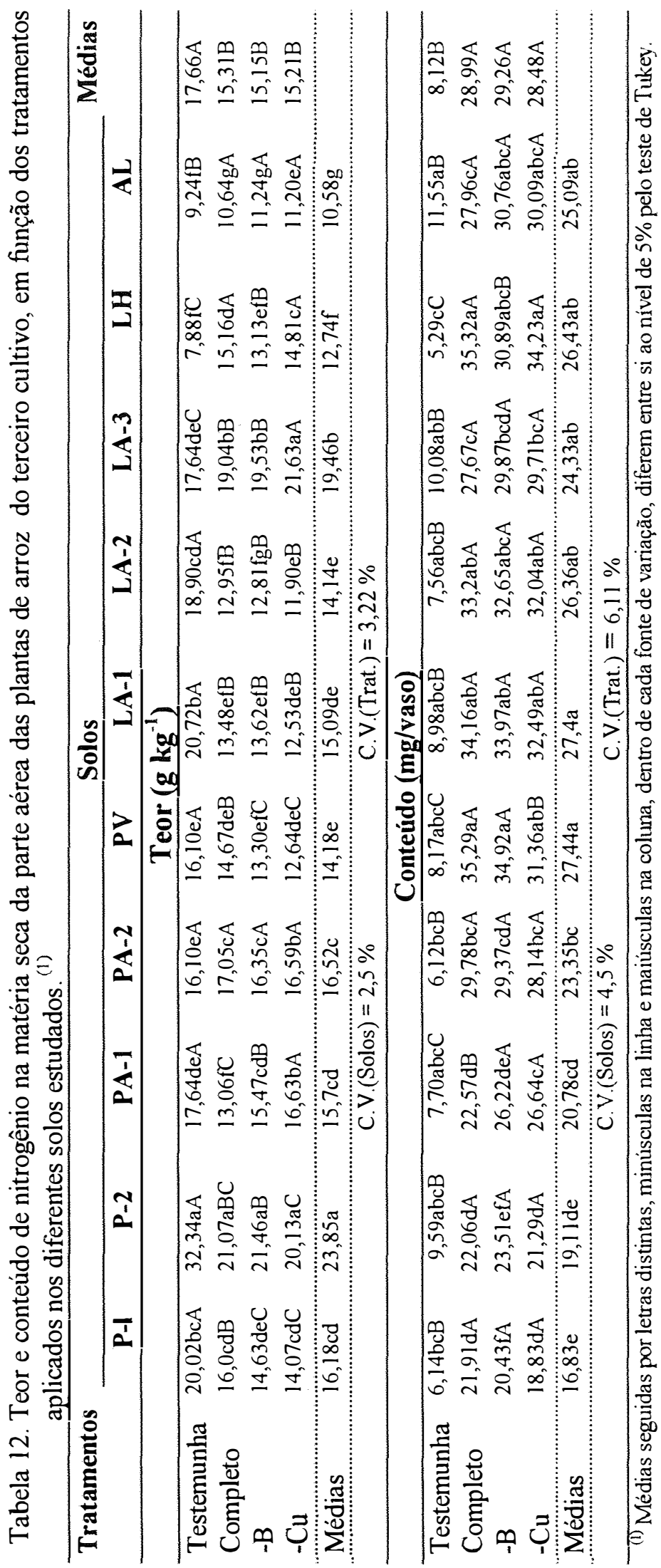




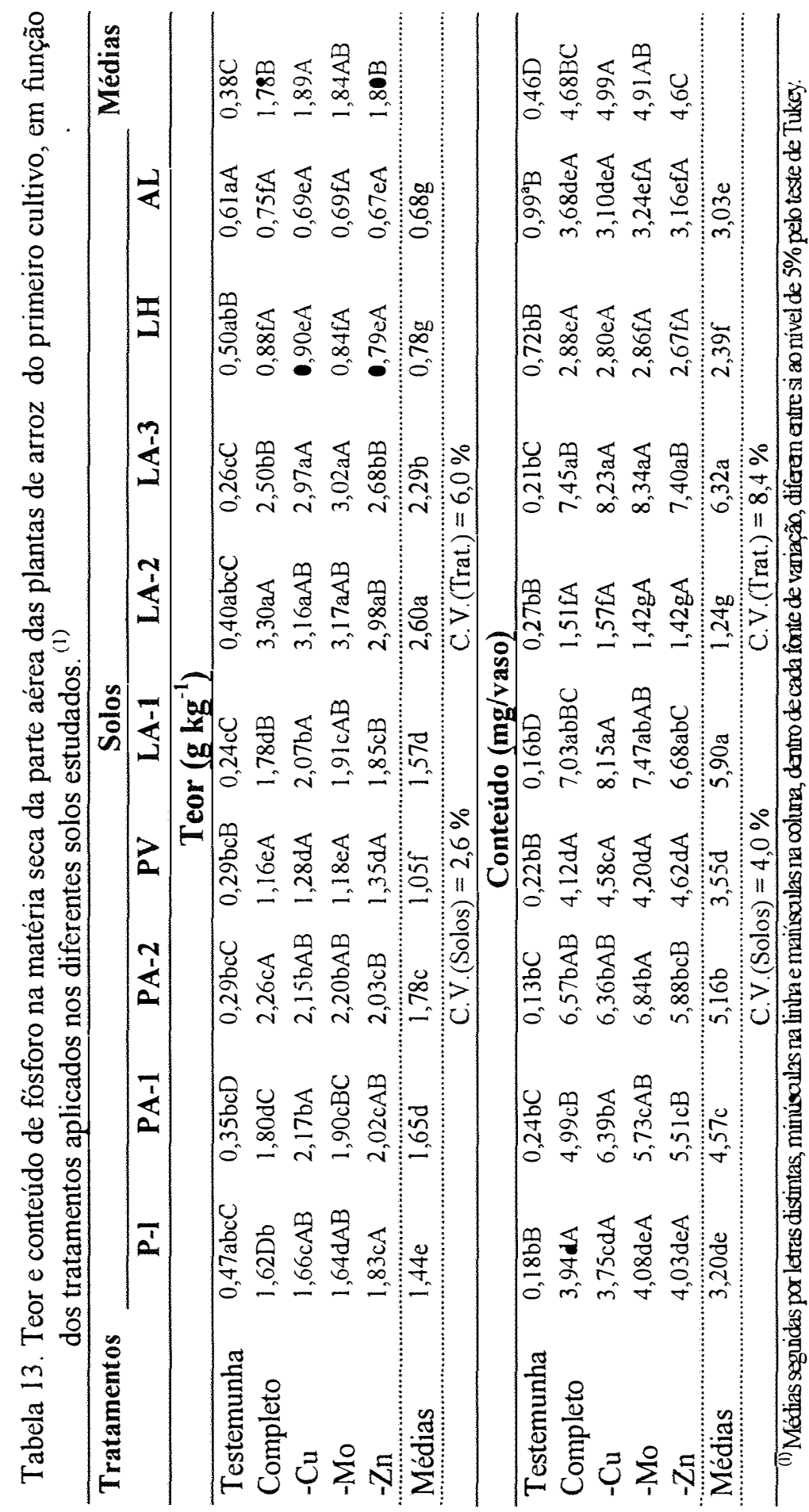




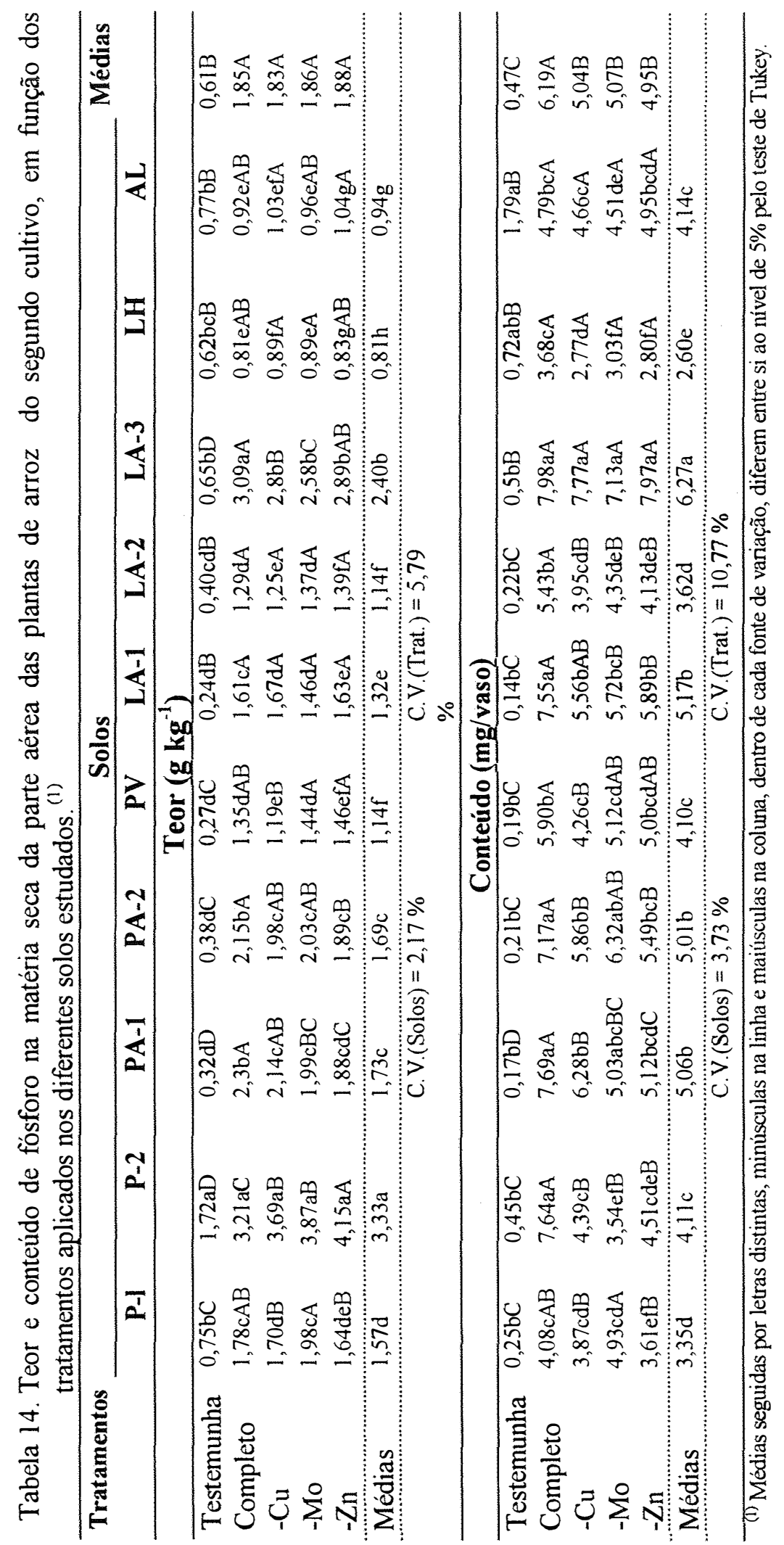




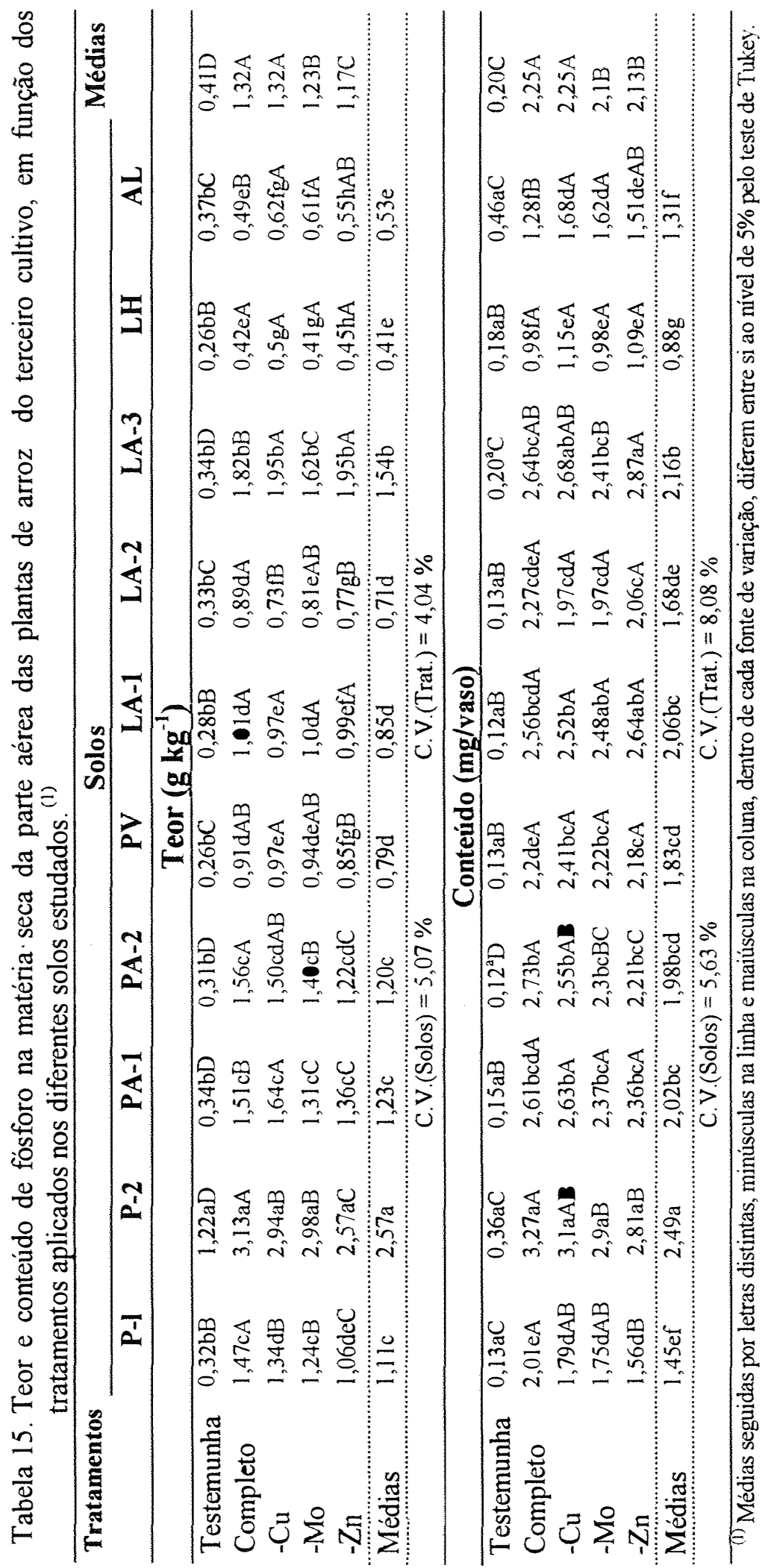




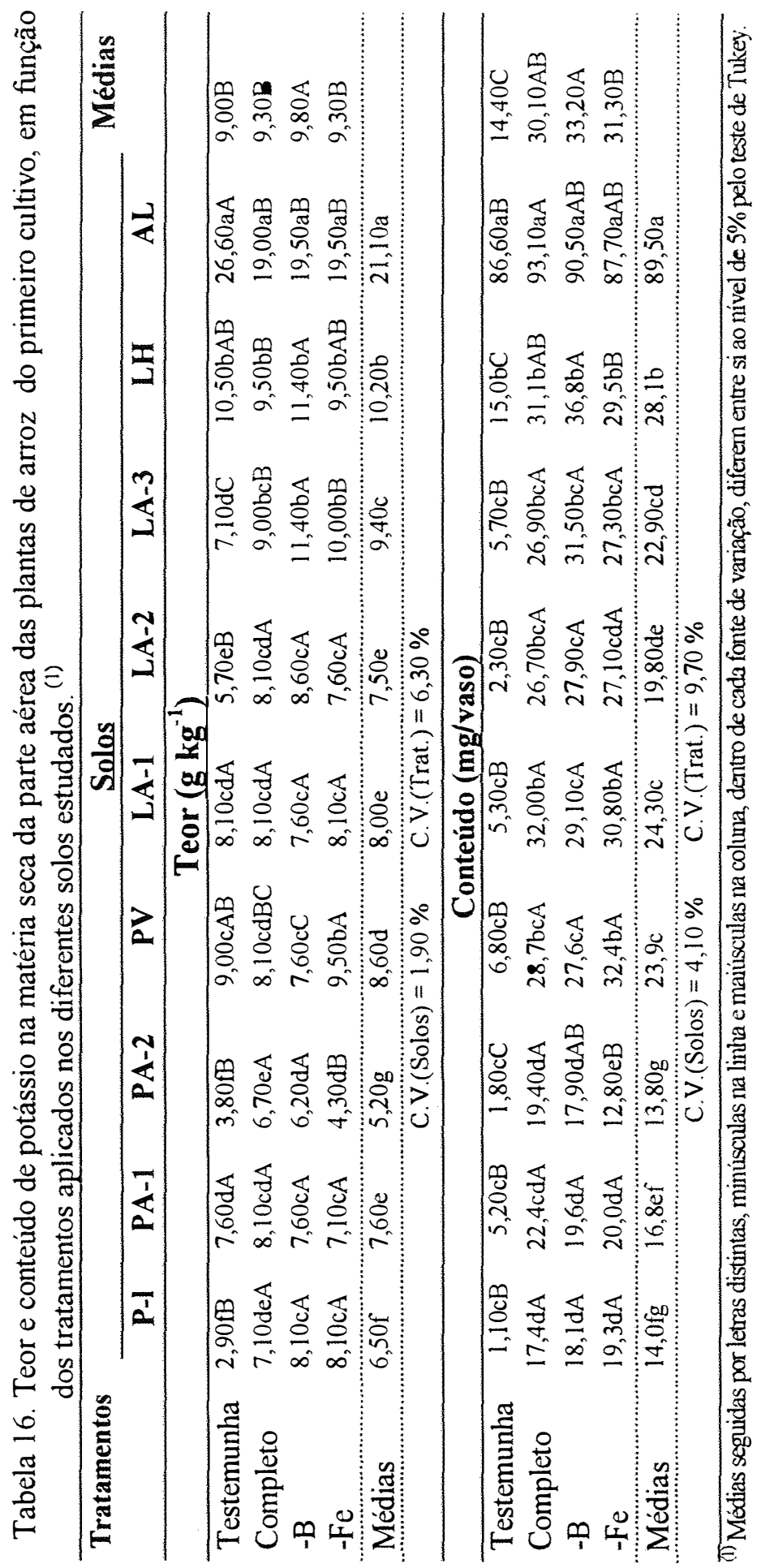




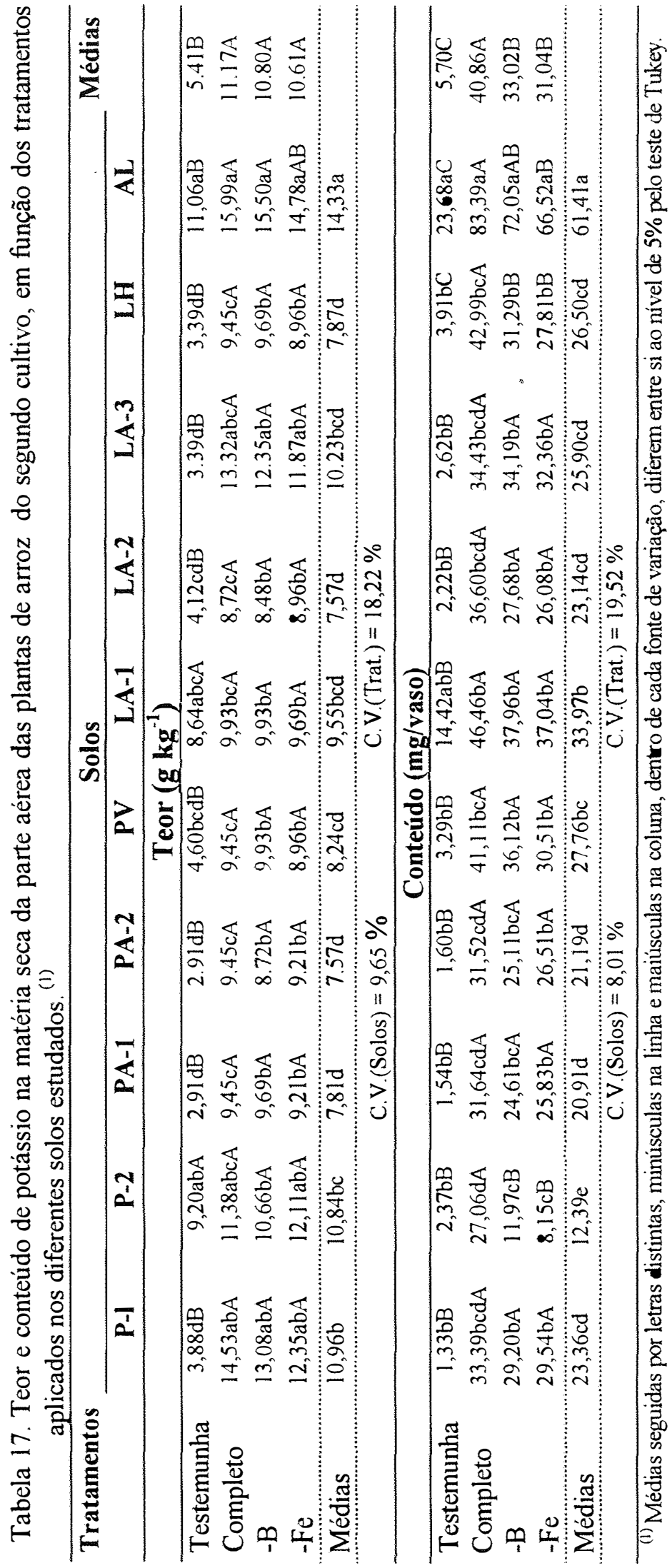









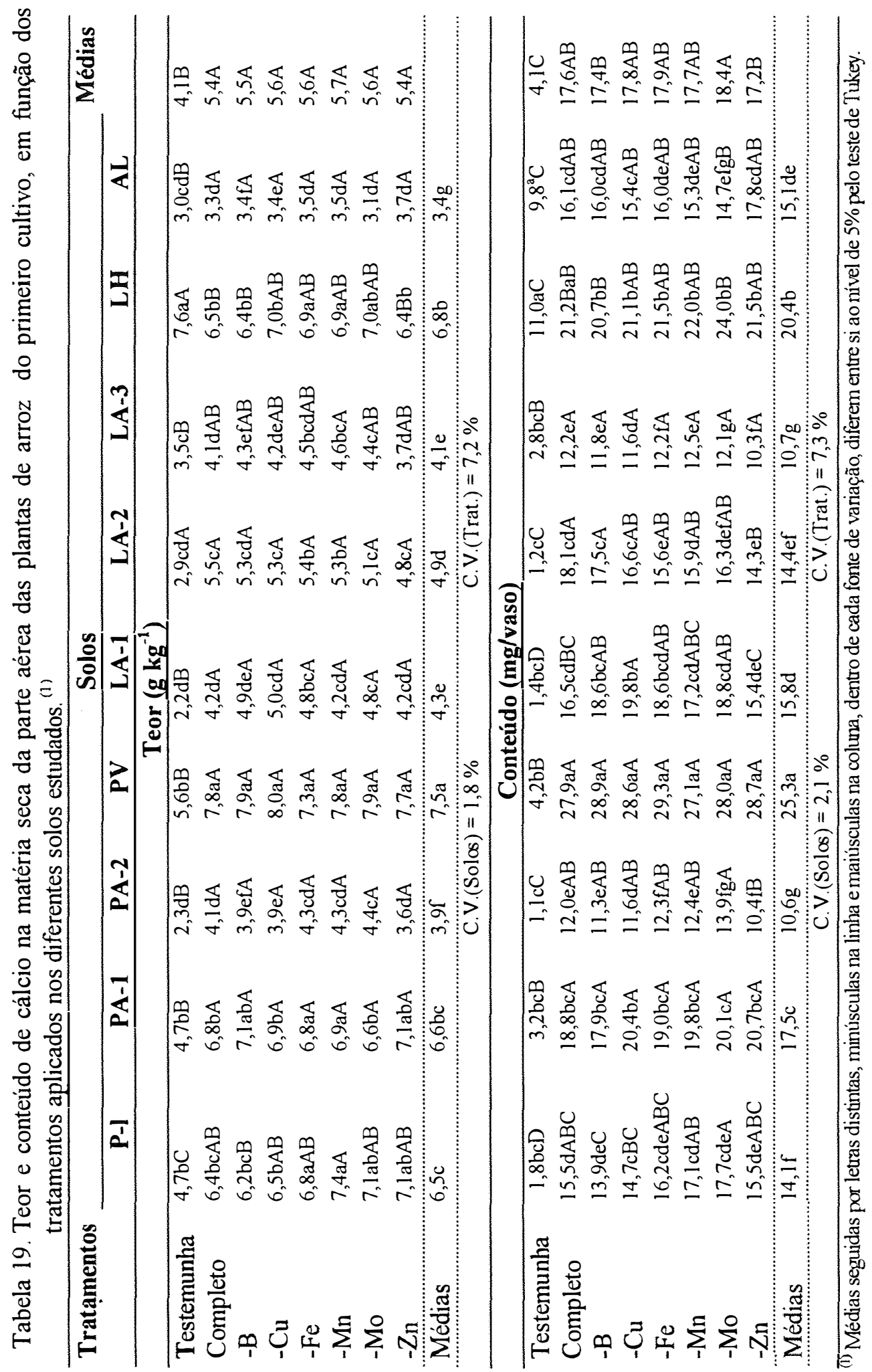




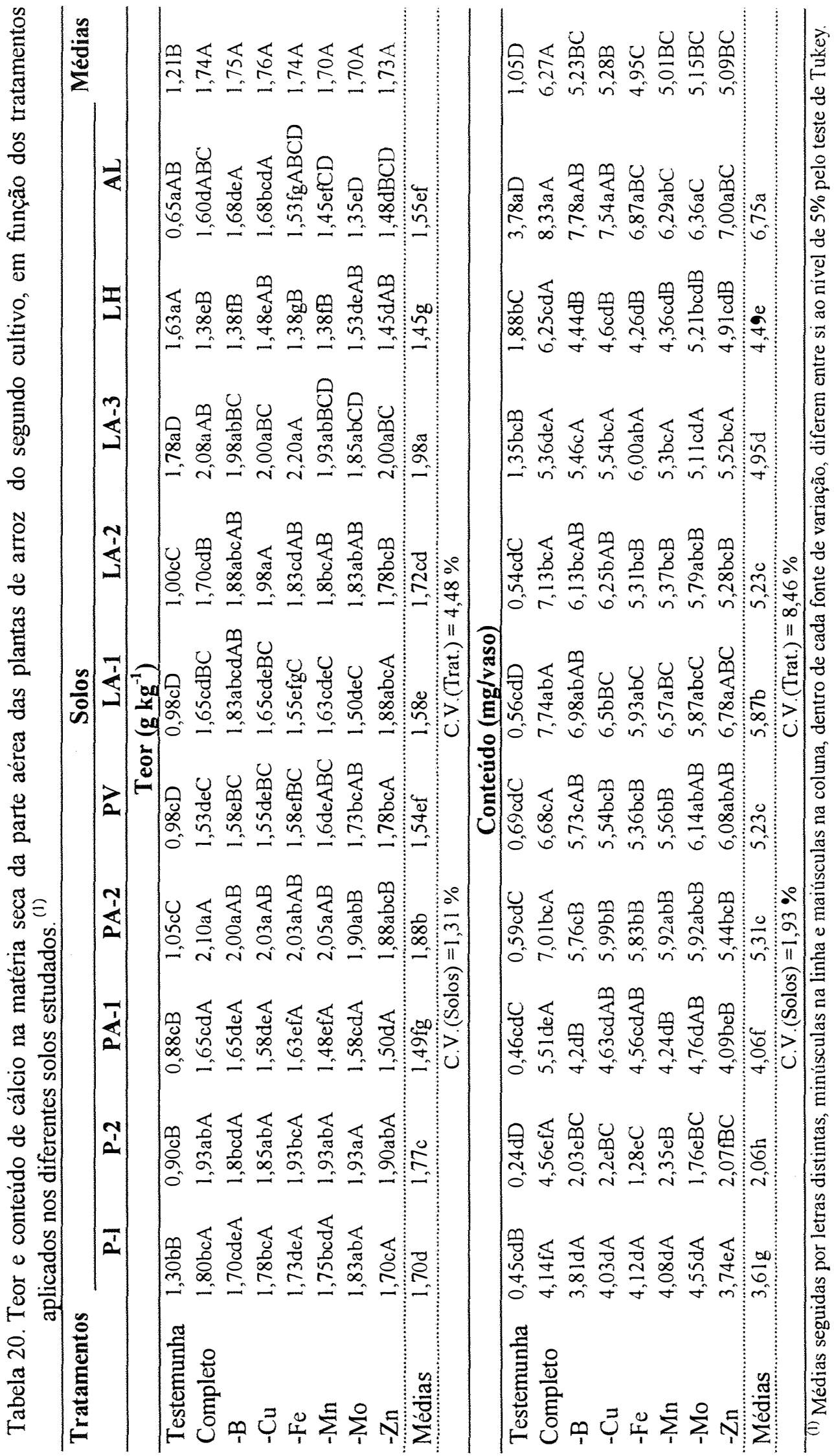




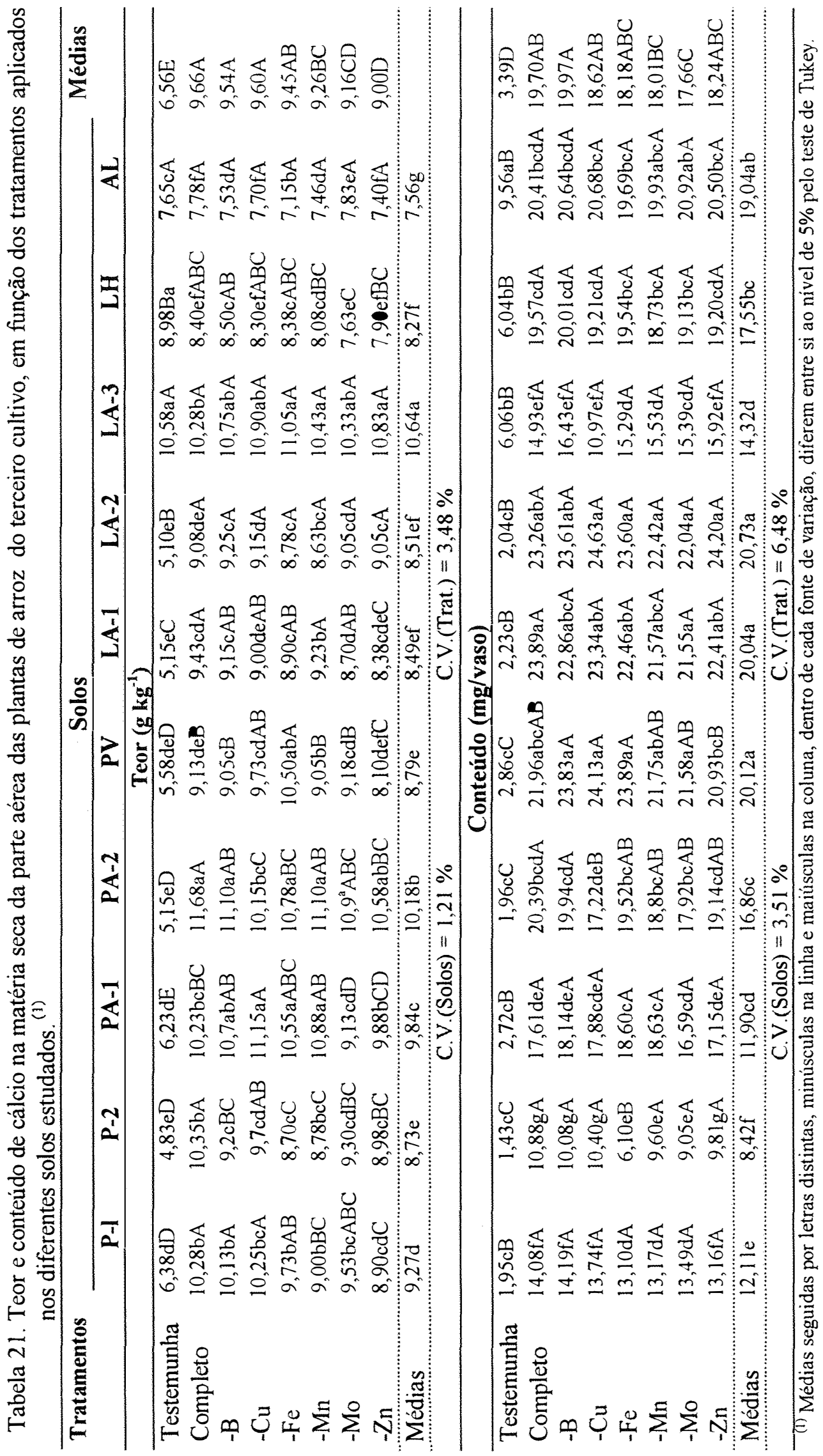




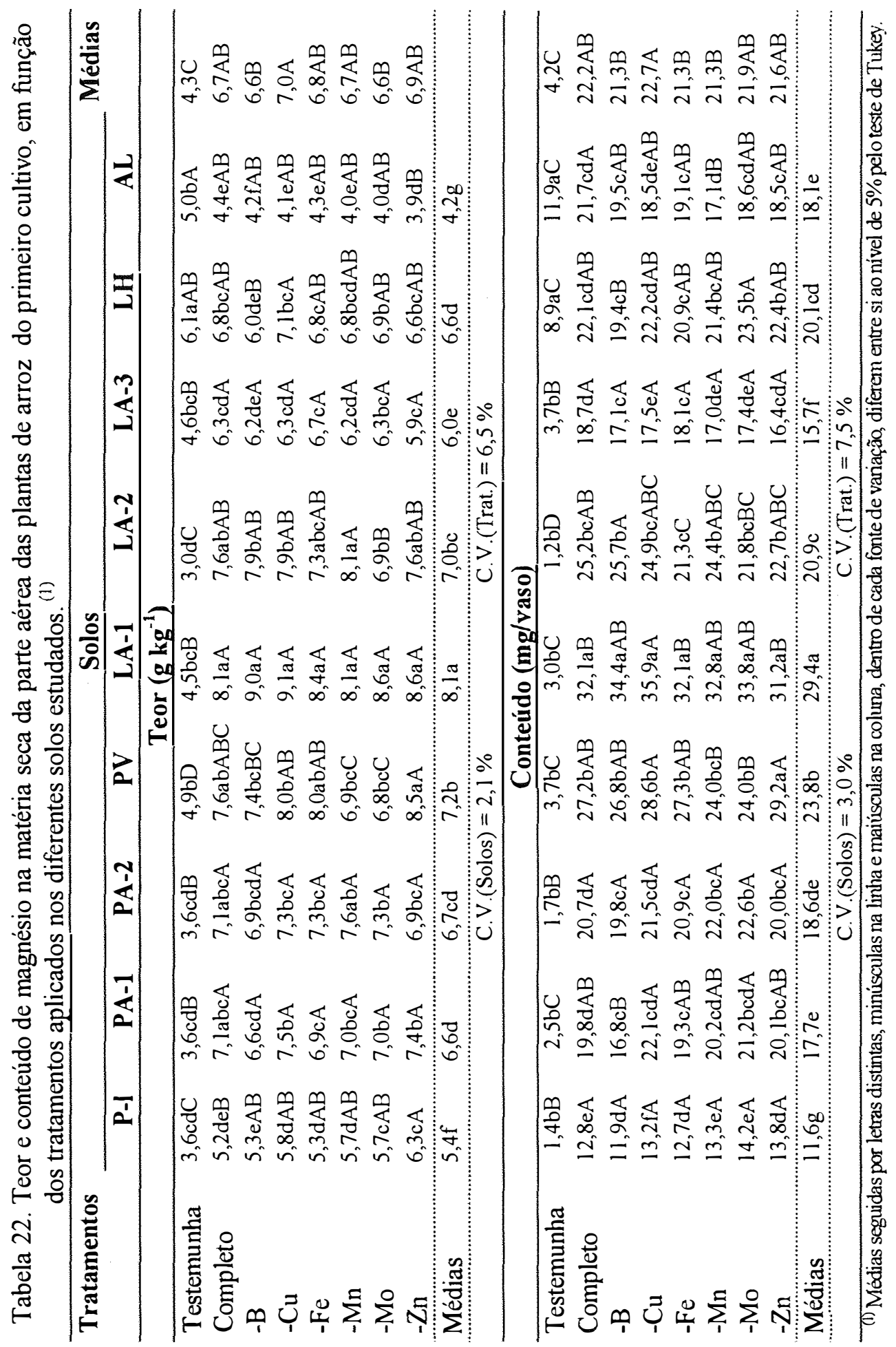




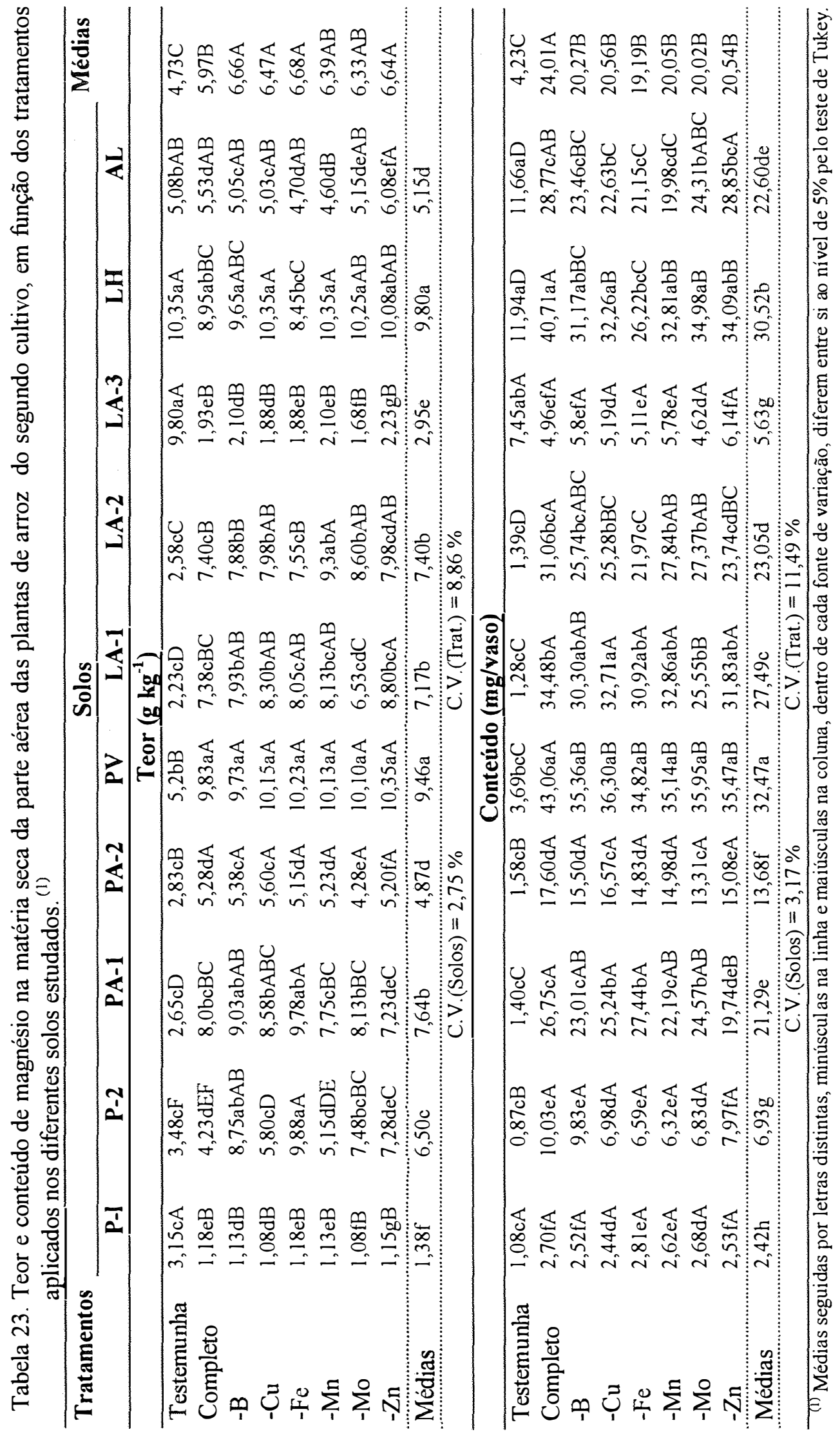




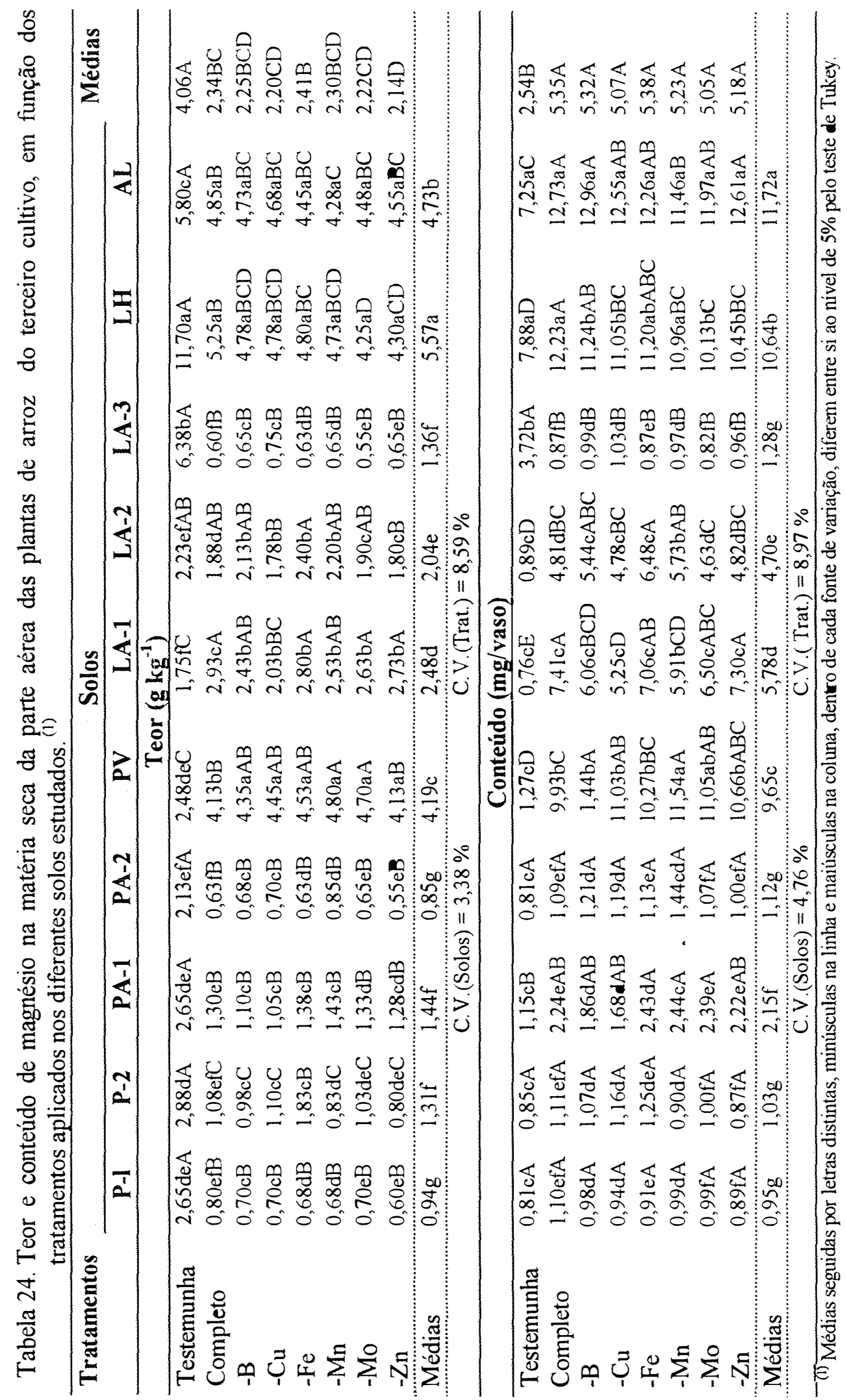




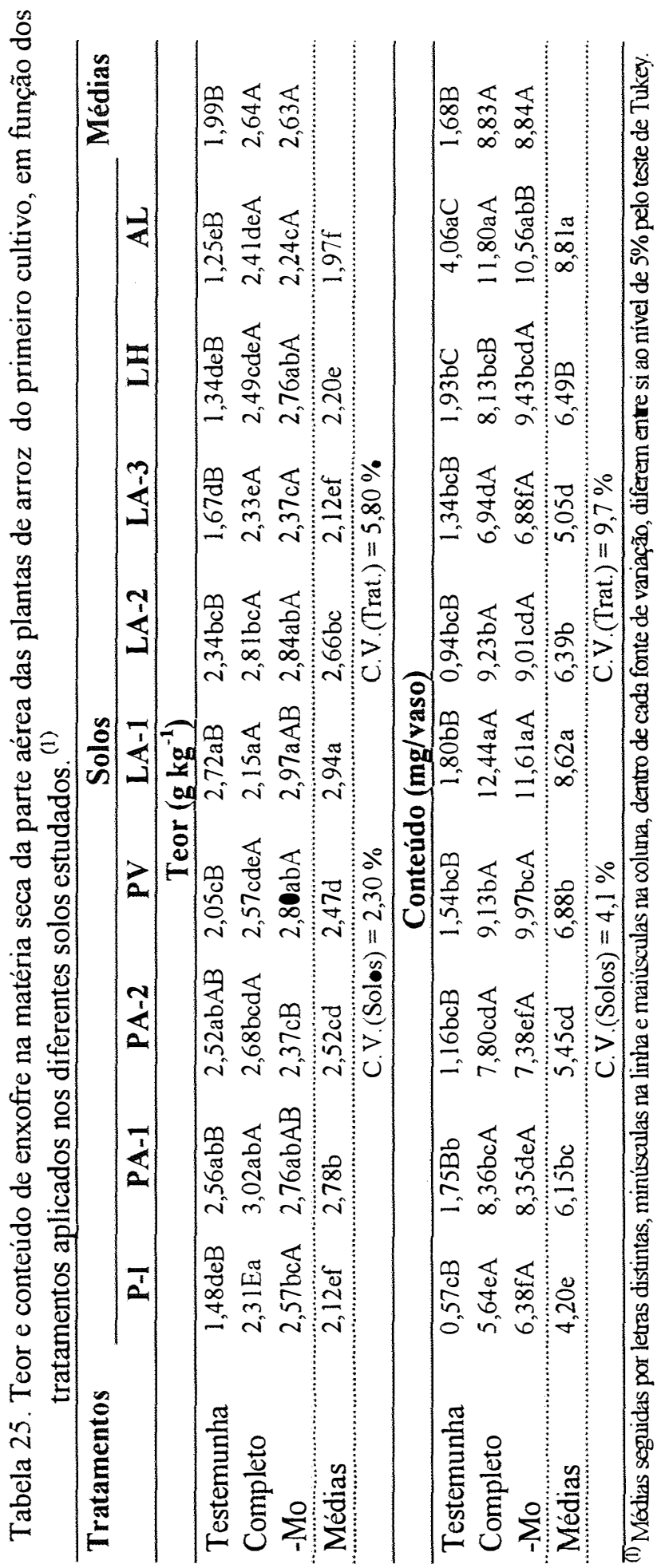




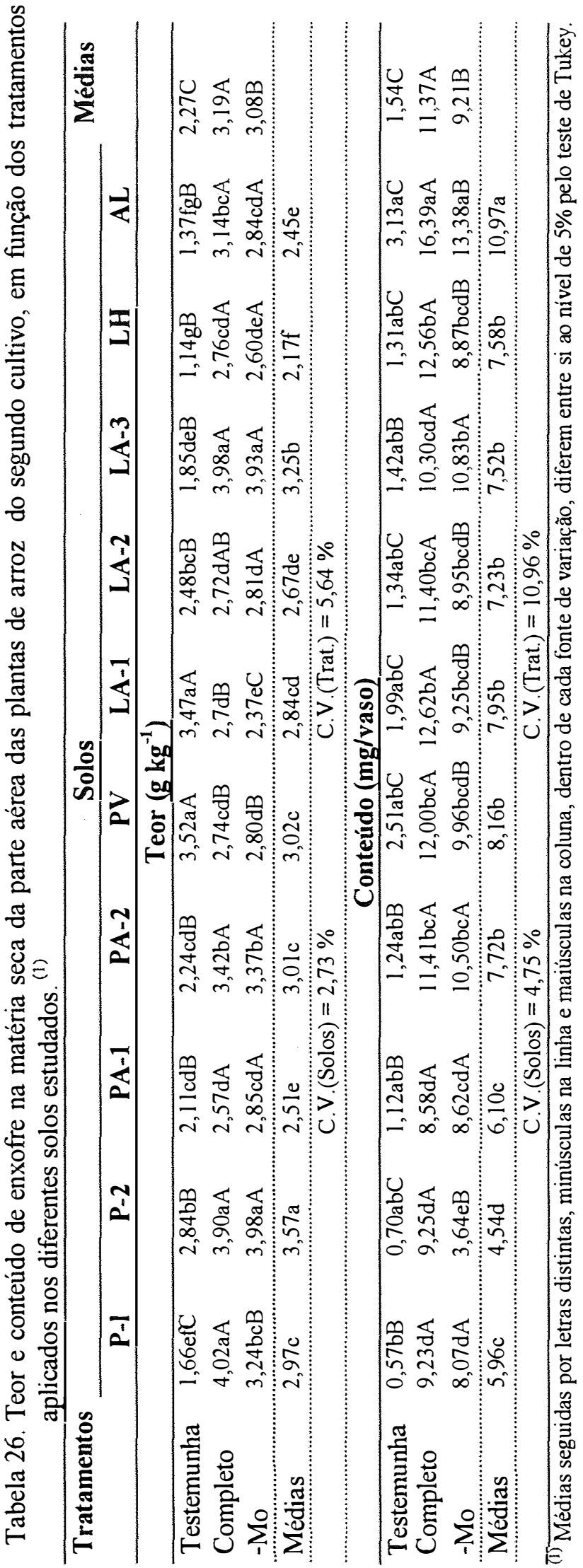




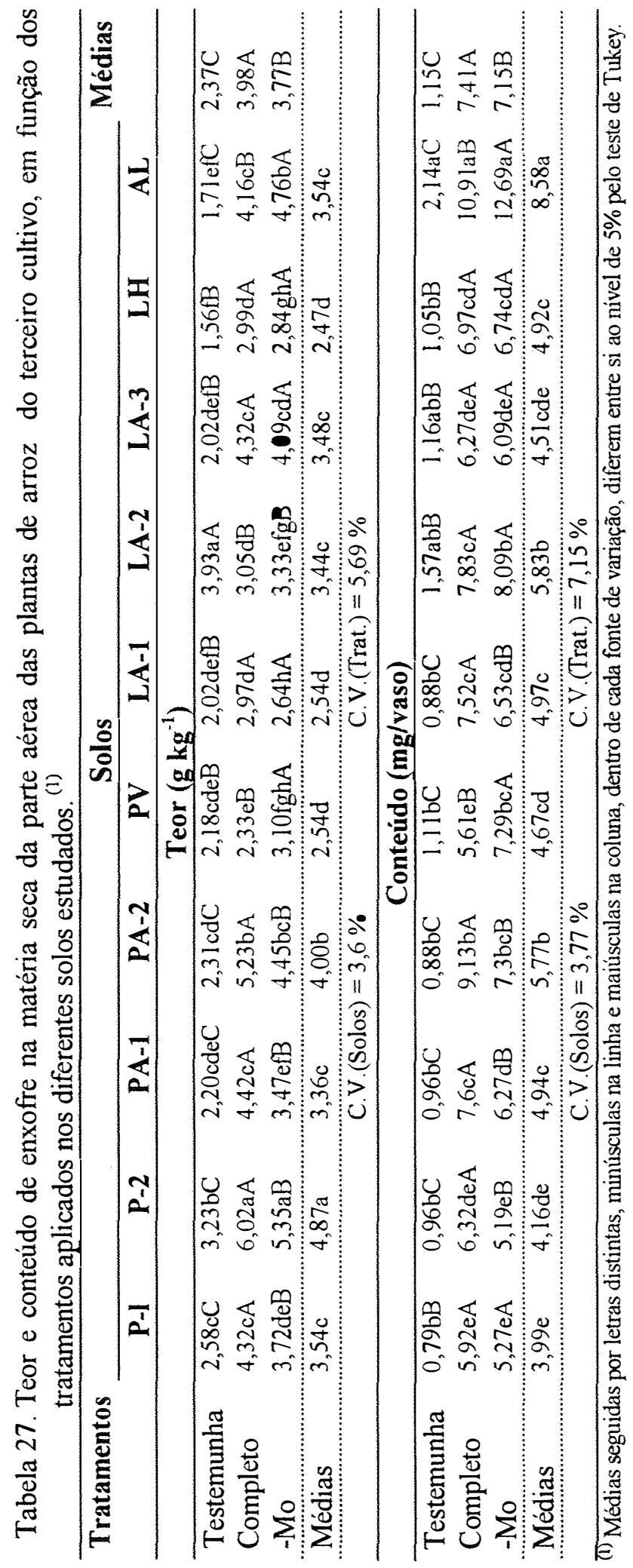




\subsubsection{Micronutrientes}

Os teores de boro na MSPA do arroz ficaram dentro da faixa normal de concentração (Barbosa Filho, 1987), durante os três cultivos (Tabelas 28, 29 e 30). Mesmo na ausência da aplicação do elemento (testemunha absoluta), verificaram-se teores elevados. Tal fato se deve aos teores disponíveis nos solos que variaram de médios a altos (Tabela 6) e ao efeito de concentração, pois para esse tratamento os conteúdos de boro foram significativamente inferiores, atingindo apenas metade dos valores obtidos nos demais tratamentos dos três cultivos.

Embora o efeito interativo mais conhecido na literatura entre boro e zinco, seja a deficiência de zinco aumentando a acumulação do boro (Graham et al., 1987), entretanto, nesse trabalho os resultados obtidos mostram que, excluindo a testemunha, os menores teores e conteúdos de boro estiveram sempre associados ao tratamento com omissão de zinco. Comportamento semelhante foi observado por Lima Filho (1991), que estudando o efeito da interação B $\times$ Zn na nutrição do cafeeiro observou também o efeito positivo do zinco sobre a absorção do boro; na ausência de zinco não houve influência do boro sobre a produção de matéria seca total.

Tem-se observado que os cereais são pouco sensiveis à aplicação de boro. Britto et al. (1971), estudando o efeito dos micronutrientes na cultura do milho e Silva \& Andrade (1983) na cultura do arroz, não obtiveram resposta à aplicação de boro. Nas condições dos latossolos amarelos da Amazônia, Cravo \& Smyth (1991) observaram tendências constantes de resposta ao boro para a cultura do milho e do feijão caupi. No mesmo tipo de solo, Rodrigues (1993) obteve resposta significativa ao boro para a cultura do dendê; a aplicação desse elemento elevou os teores nas folhas e corrigiu os sintomas de deficiência na planta.

Os teores médios de cobre na MSPA do arroz no tratamento com omissão do elemento foram estatisticamente inferiores aos demais, incluindo a testemunha absoluta, durante os três cultivos (Tabelas 31, 32 e 33), atingindo porém, níveis adequados (Barbosa Filho, 1987). No terceiro cultivo observou-se que os teores diminuíram significativamente nos solos mais argilosos (latossolos) e aumentaram nos 
mais arenosos. Vários fatores podem está contribuindo para as variações observadas, como por exemplo: menor disponibilidade causada pela adsorção do cobre pelos hidróxidos de ferro e alumínio; formação de complexos orgânicos solúveis; mineralização da matéria orgânica do solo; diminuição do efeito residual e outros. Segundo Loué (1993), a disponibilidade do cobre depende muito dos fatores que afetam sua fixação sobre o complexo argilo-húmico do solo.

Os teores de ferro na MSPA diminuíram do primeiro cultivo (Tabela 34) para o segundo cultivo (Tabela 35), ficando nos solos P-1, PA-1, LH, PV, LA-1 abaixo da faixa normal de concentração (Barbosa Filho, 1987). No terceiro cultivo (Tabela 36) os teores de ferro na MSPA aumentaram, atingindo níveis adequados. Este aumento foi devido, muito provavelmente, a uma redução média do $\mathrm{pH}$ de quase duas unidades em relação ao pH obtido após a incubação do solo, antes do primeiro cultivo (Tabela 45). A influência do $\mathrm{pH}$ da solução do solo sobre a estabilidade dos quelatos de Fe e sobre a disponibilidade e absorção desse elemento pelas plantas é bem conhecida na literatura (Norvell, 1972; Lindsay \& Shwab, 1982; Lindsay, 1984).

Houve resposta à aplicação do manganês. De modo geral, na ausência da aplicação desse elemento, a MSPA do arroz apresentou teores e conteúdos menores nos três cultivos (Tabelas 37, 38 e 39). Os teores de manganês na MSPA do arroz cultivado nos solos $\mathrm{LH}$ e AL mantiveram-se durante os três cultivos acima da faixa de concentração considerada adequada por Malavolta (1997), mesmo na omissão desse nutriente. Os maiores teores observados na MSPA do arroz cultivado nesses solos estão diretamente relacionados aos altos teores de manganês revelados pela análise inicial dos solos (Tabela 6).

Nos solos P-1, PA-1, PA-2, LA-1, LA-2 e LA-3 a aplicação do molibdênio promoveu aumentos significativos nos teores e conteúdos desse elemento na MSPA do arroz no primeiro cultivo (Tabela 40). Entretanto, apenas para o tratamento completo dos solos P-1, PA-1 e LA-1 os teores obtidos atingiram a faixa normal de concentração considerada adequada por Barbosa Filho (1987). A análise química da 
MSPA do arroz realizada após o terceiro cultivo mostrou que os teores e conteúdos de molibdênio diminuíram drasticamente em relação ao primeiro cultivo (Tabelas 40 e 41).

Os teores e conteúdos de zinco na MSPA do arroz durante os três cultivos (Tabelas 42, 43 e 44) foram significativamente superiores nos tratamentos onde esse elemento foi aplicado, exceto nos solos LH e AL. Nesses solos, os teores de zinco disponível já altos $\left(3,3\right.$ a $\left.4,4 \mathrm{mg} \mathrm{dm}^{-3}\right)$ possibilitaram que os teores na MSPA da testemunha absoluta, mesmo após o terceiro cultivo, fosse superior aos demais tratamentos. De modo geral, observou-se que os teores desse elemento na MSPA do arroz diminuiu gradativamente do primeiro para o terceiro cultivo, refletindo a redução do efeito residual do elemento. No tratamento com omissão de zinco, os teores do elemento na MSPA do arroz nos solos P-1, P-2, PA-1, PA-2, PV, LA-1 e LA-2 ficaram, geralmente, abaixo da concentração adequada (Malavolta, 1997).

A absorção do zinco foi influenciada pela presença de outros micronutrientes como $\mathrm{Cu}, \mathrm{Fe}$ e $\mathrm{Mn}$. Nos solos podzóis, por exemplo, a ausência da aplicação de ferro, elevou significativamente os teores de zinco na MSPA do arroz. Resultados semelhantes foram observados por Galrão et al. (1981), estudando o efeito de micronutrientes na produção e composição química do arroz. Tem-se encontrado resposta à aplicação de zinco para o arroz cultivado nos solos do cerrado e outros, com características semelhantes (Galrão et al.,1978; Galrão, 1984; Silva \& Andrade, 1987)

\subsection{Análise química dos solos}

\subsection{1 $\mathrm{pH}$}

Vários autores (Boyer, 1982; Loué, 1993; Malavolta, 1997) têm enfatizado o papel primordial que o $\mathrm{pH}$ desempenha como um dos principais fatores da disponibilidade dos nutrientes. A dinâmica dos micronutrientes no solo, sobretudo a passagem das reservas para as formas disponíveis é fortemente influenciada pelo $\mathrm{pH}$. $\mathrm{O}$ aumento do $\mathrm{pH}$ reduz a solubilidade e a absorção de $\mathrm{Co}, \mathrm{Cu}, \mathrm{Fe}, \mathrm{Zn}$ e mais particularmente Mn, e aumenta a do Mo. 


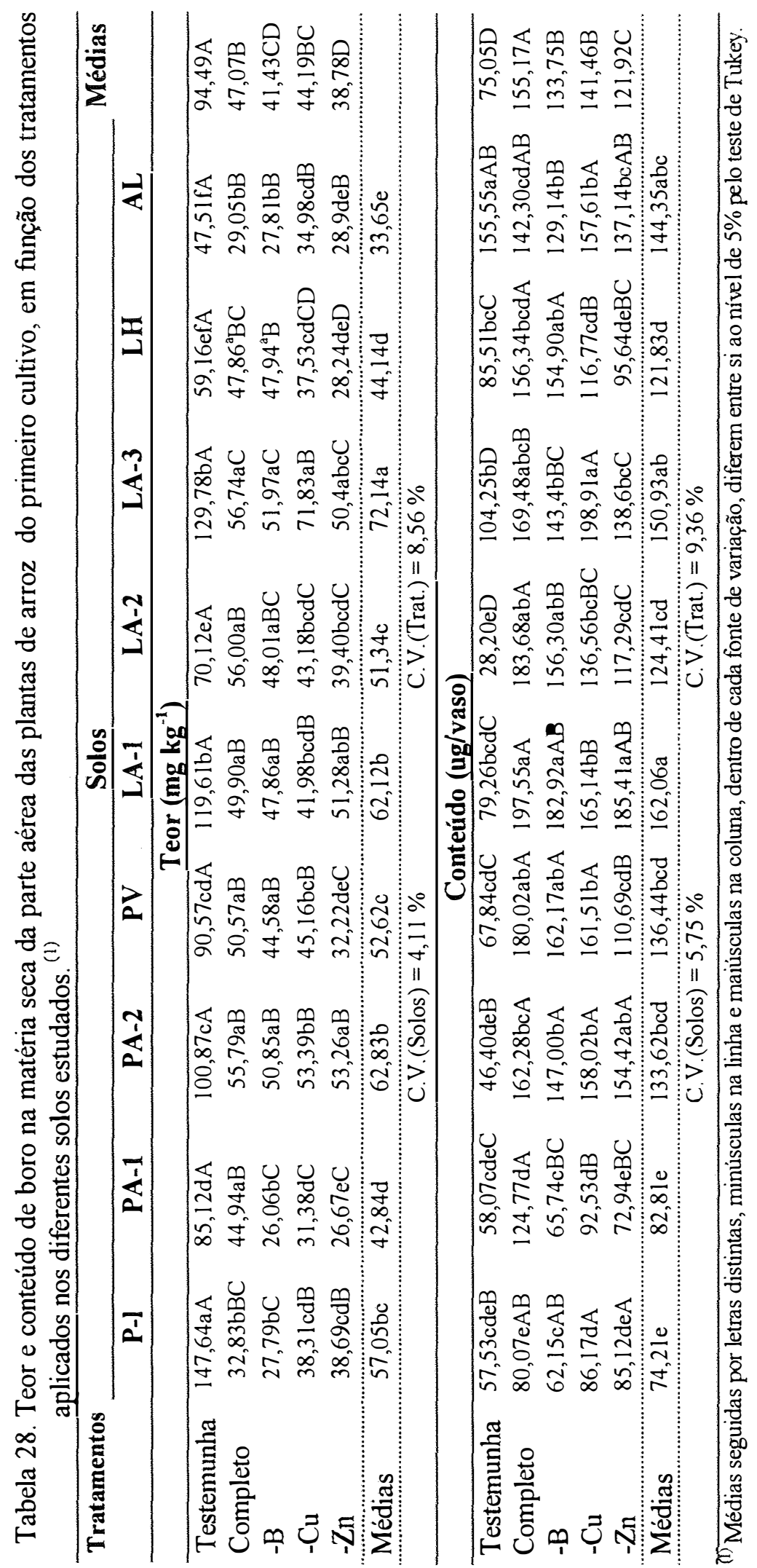




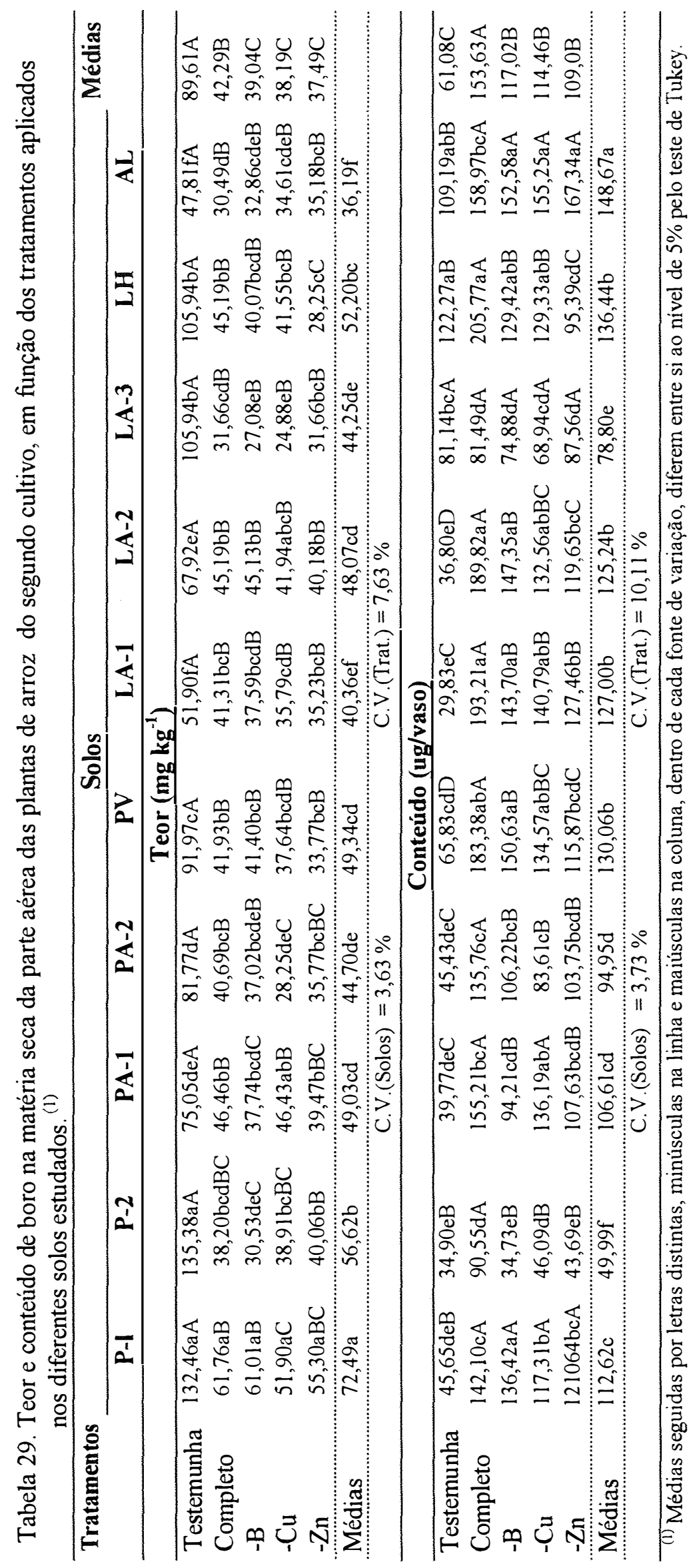




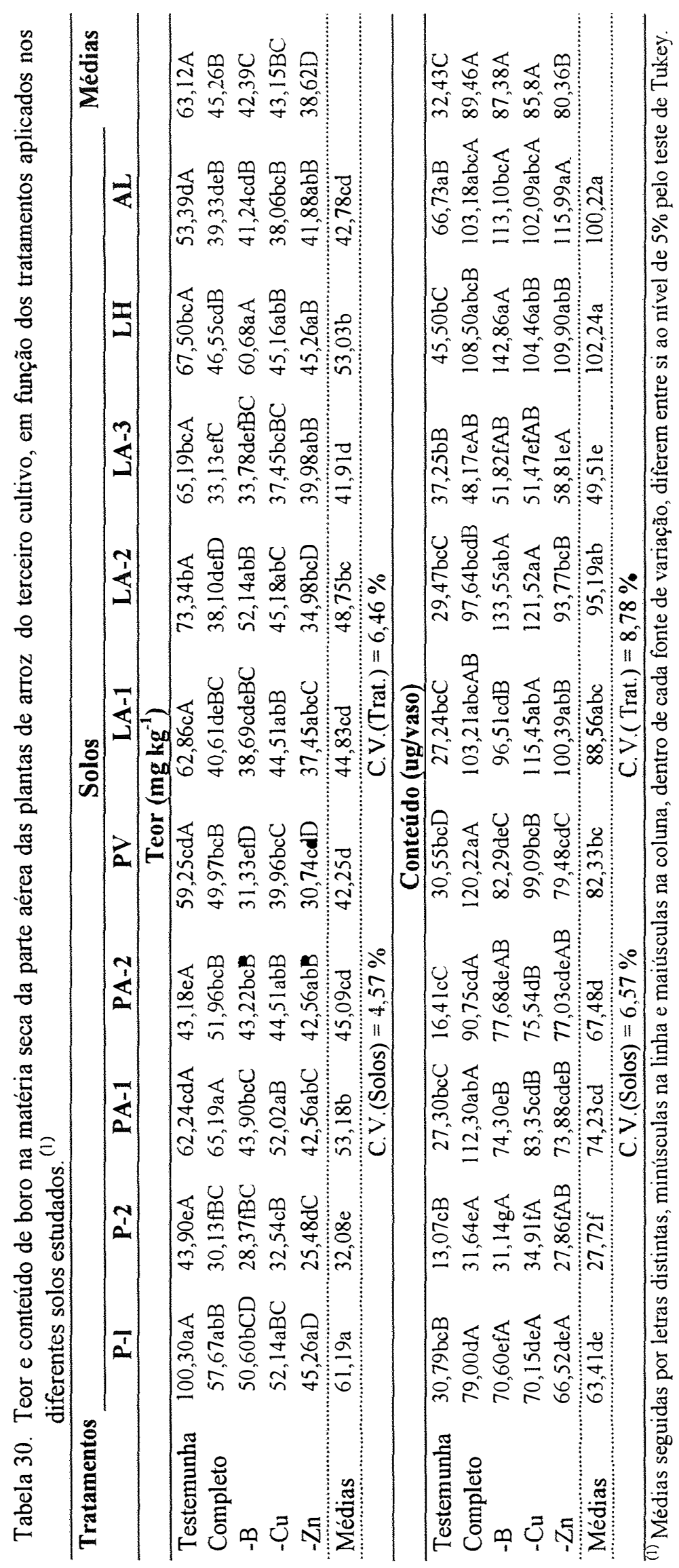




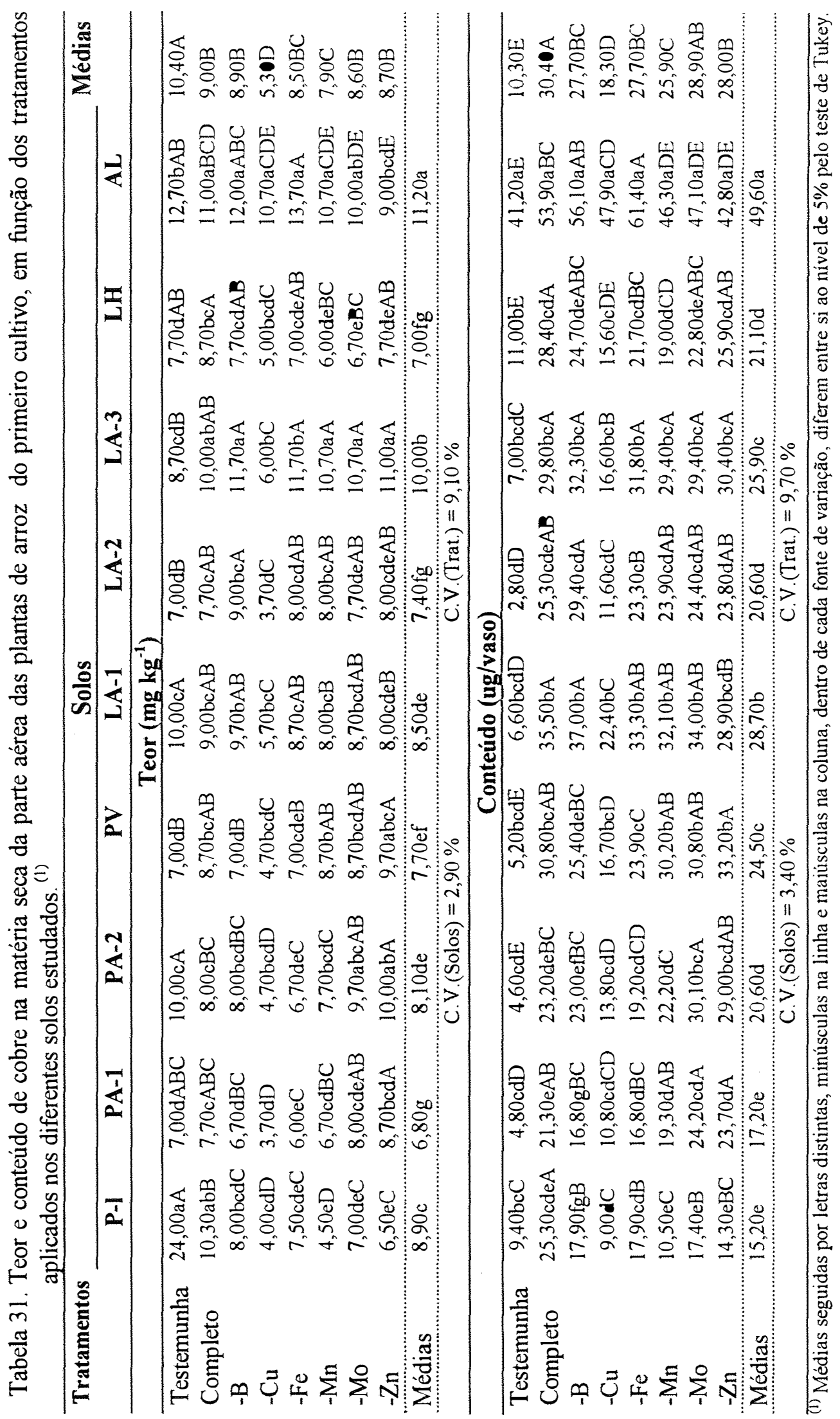




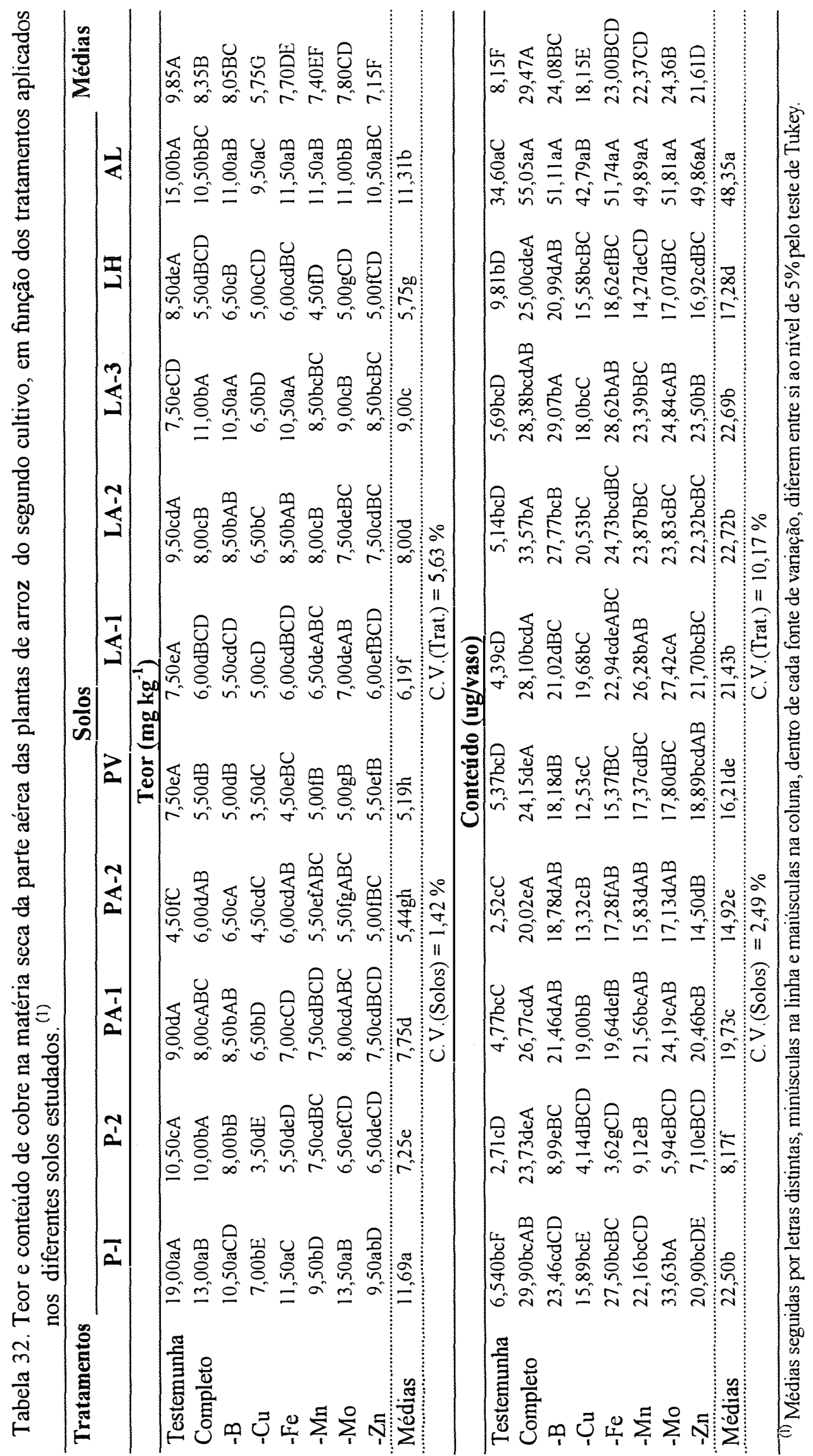




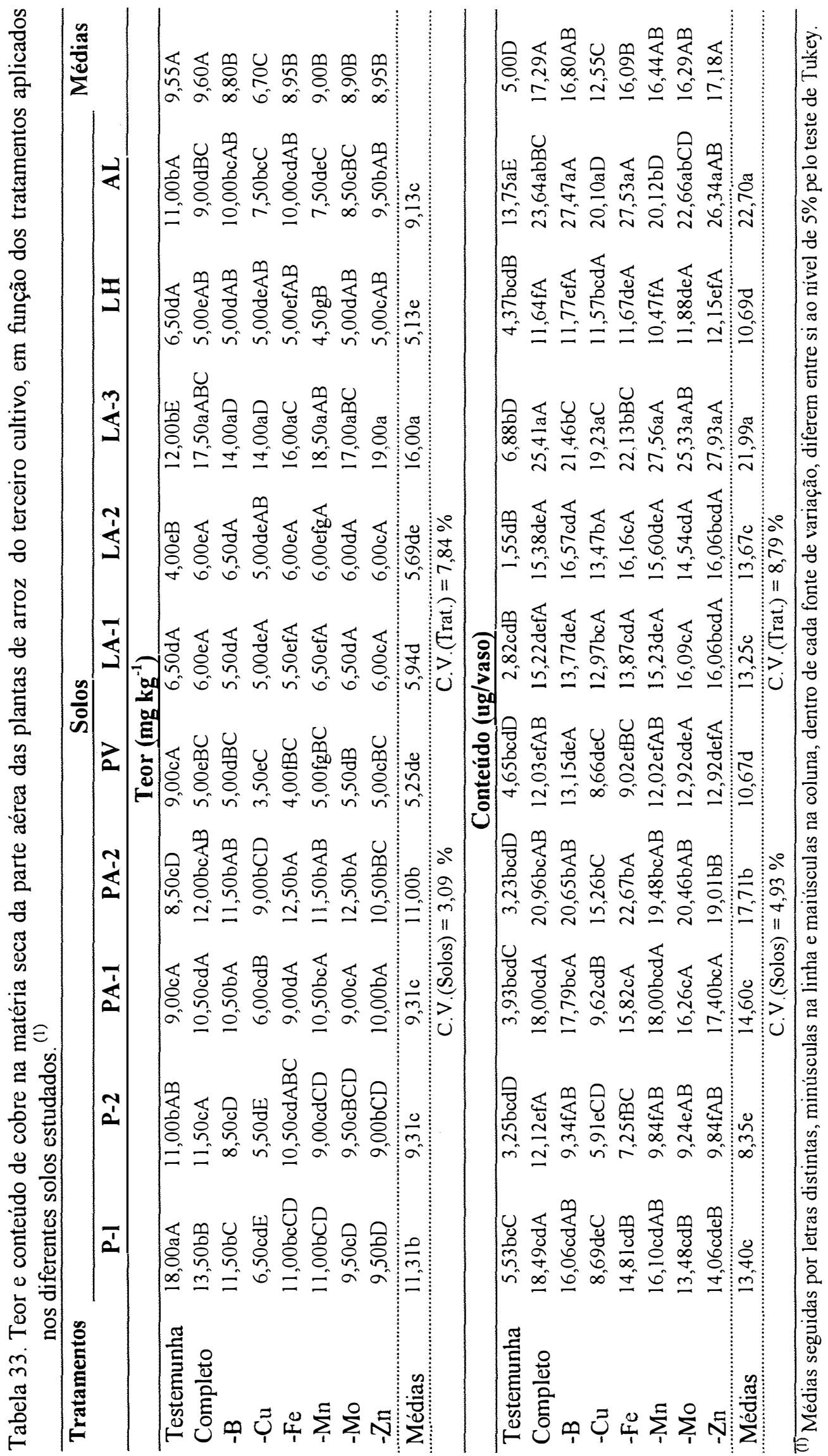




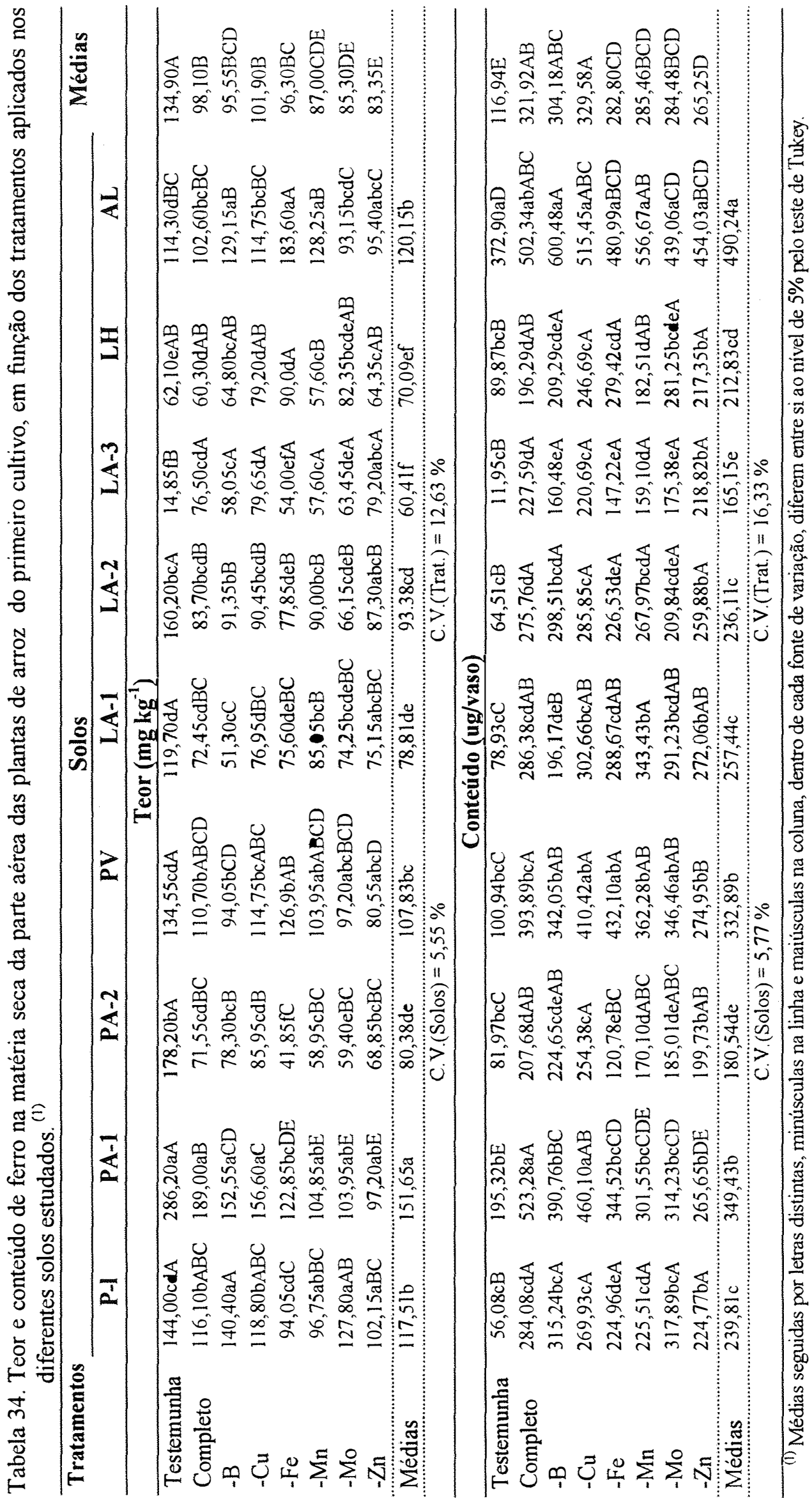




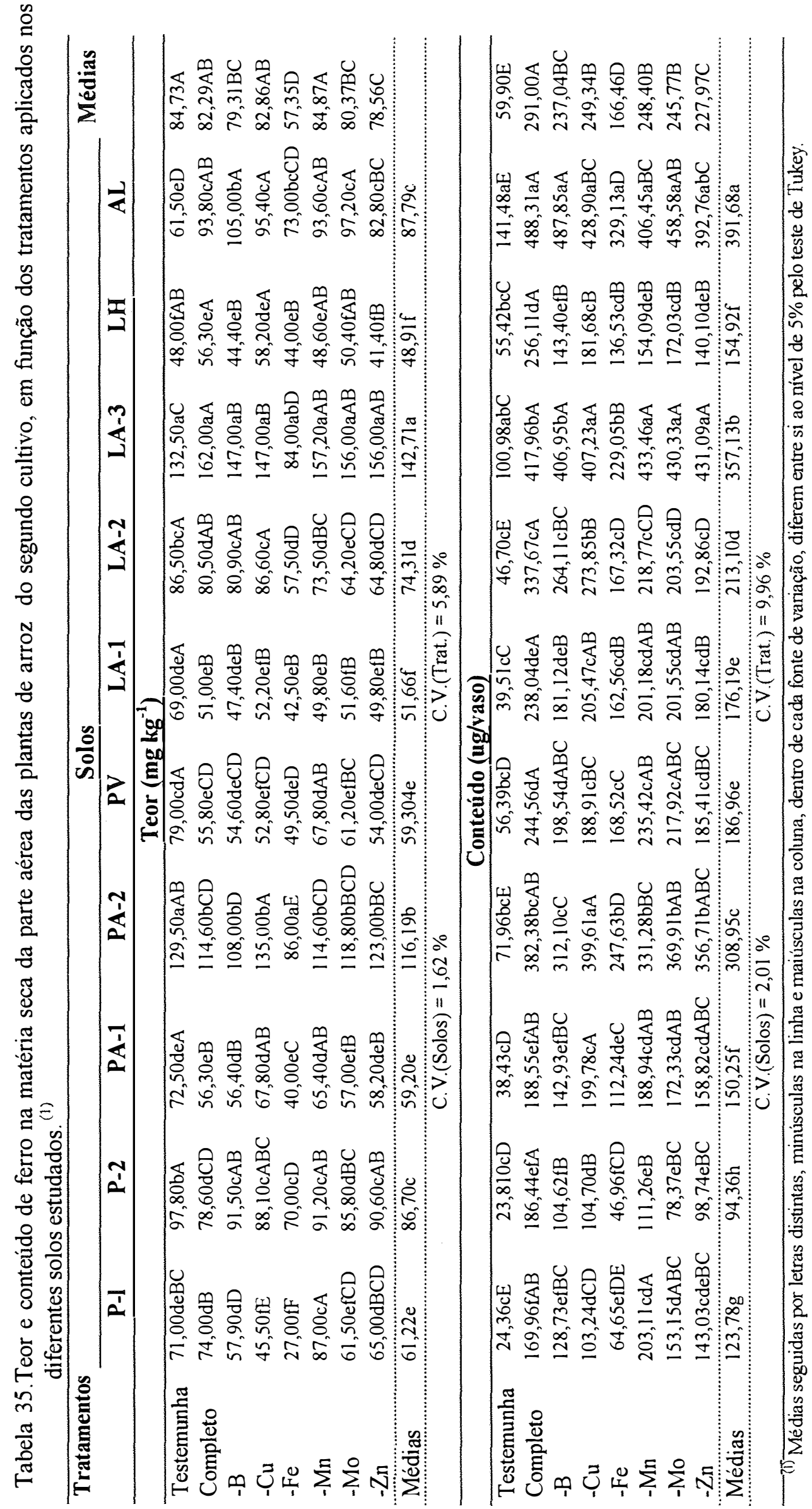




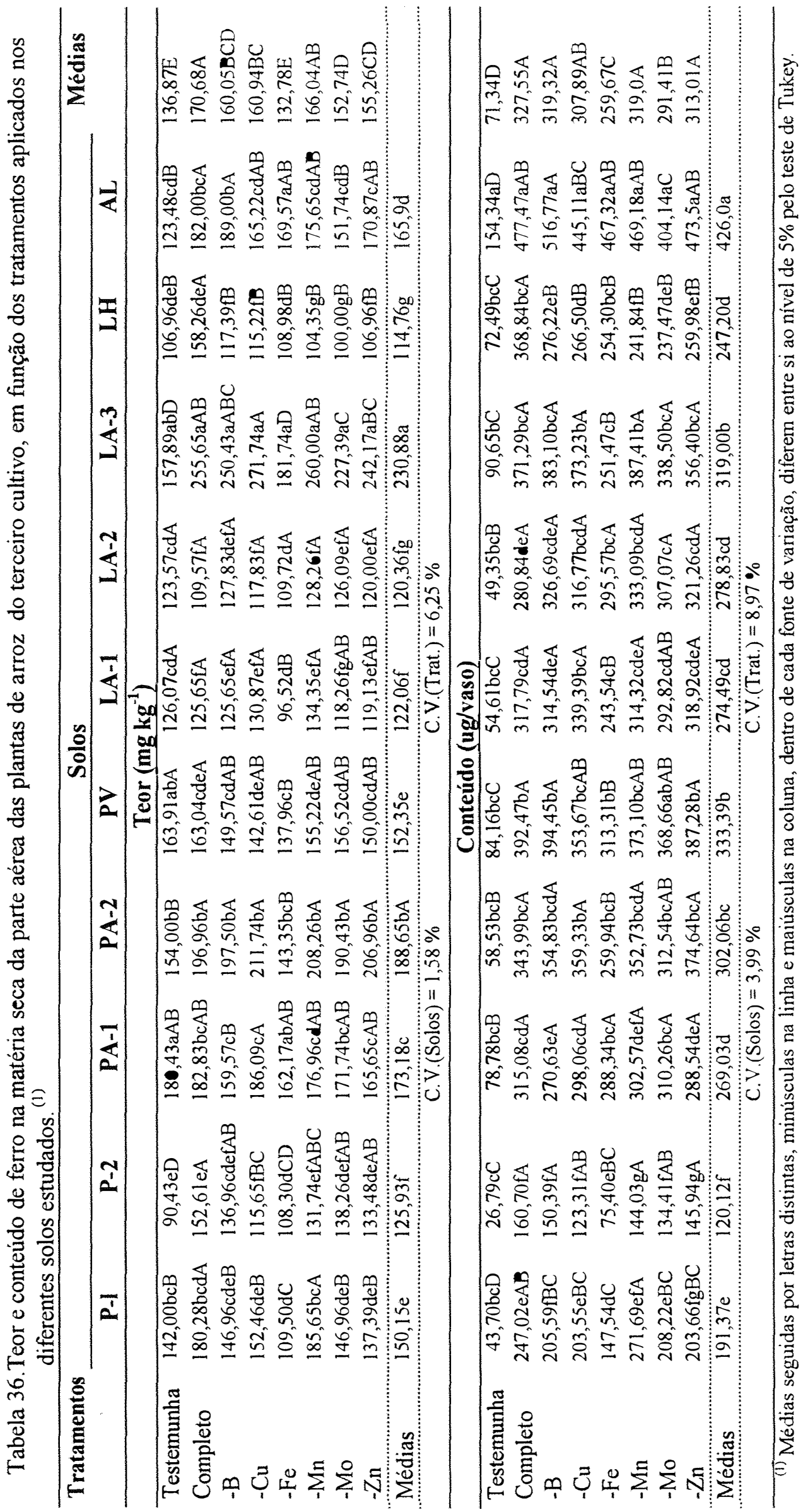




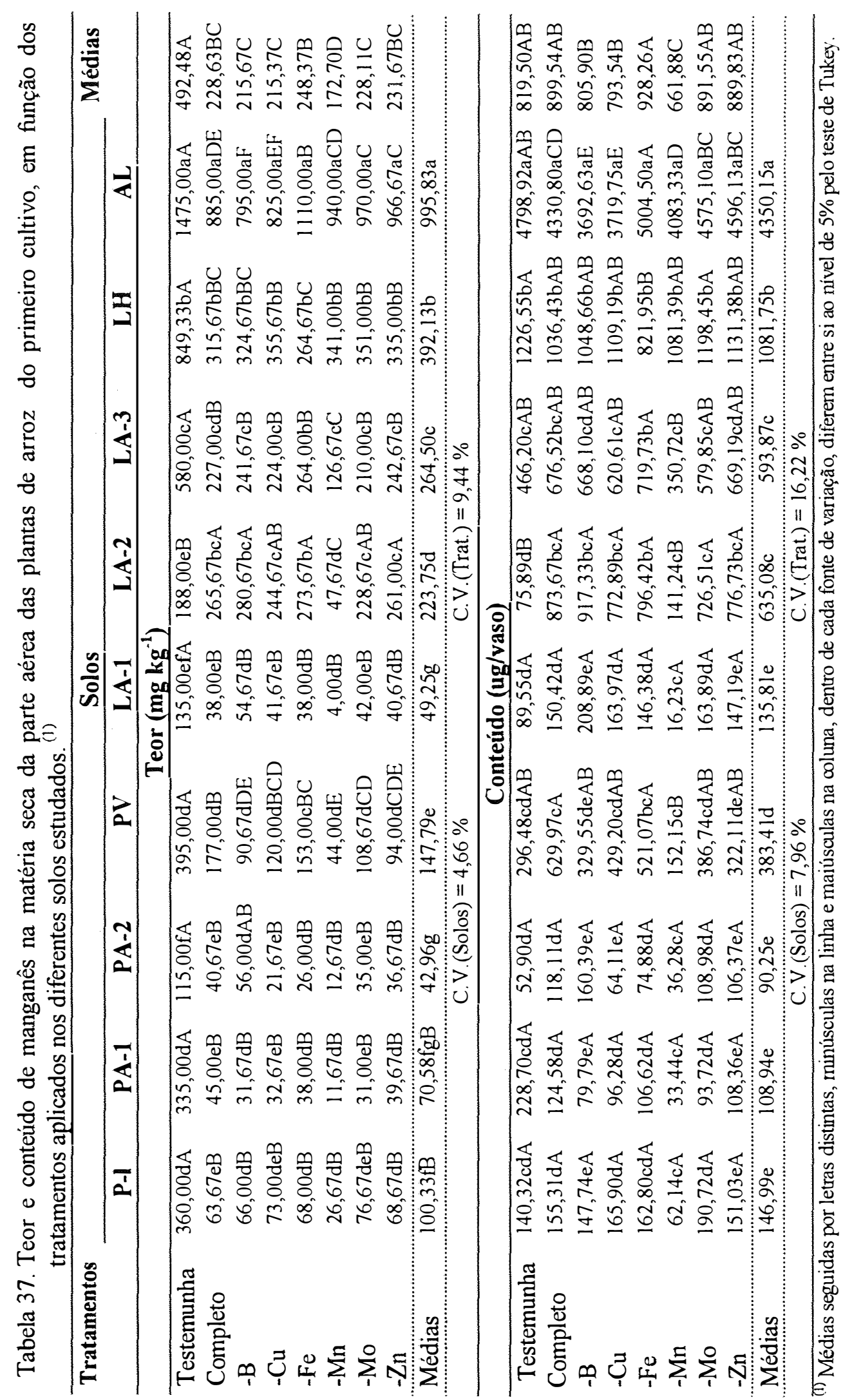




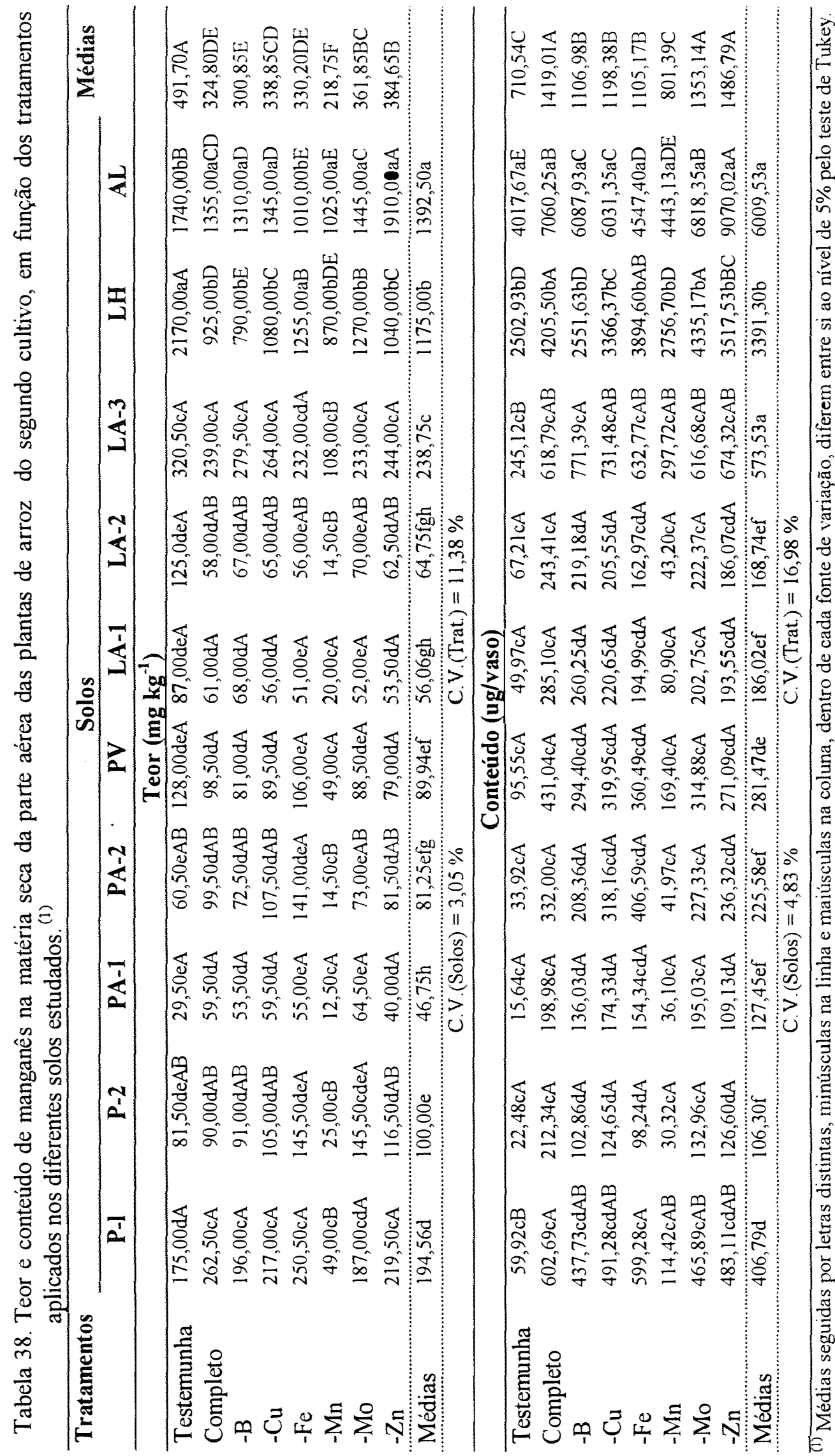




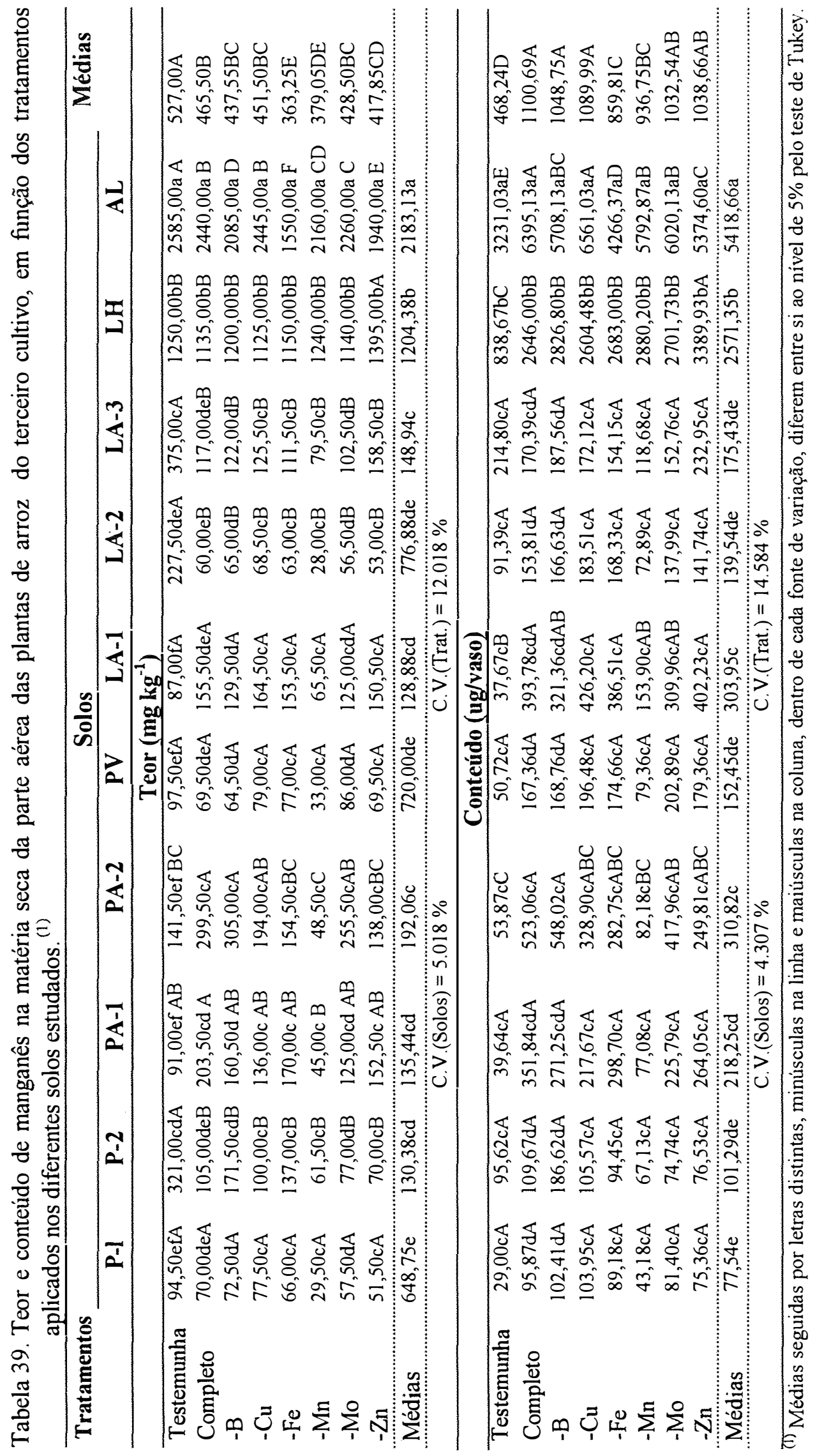




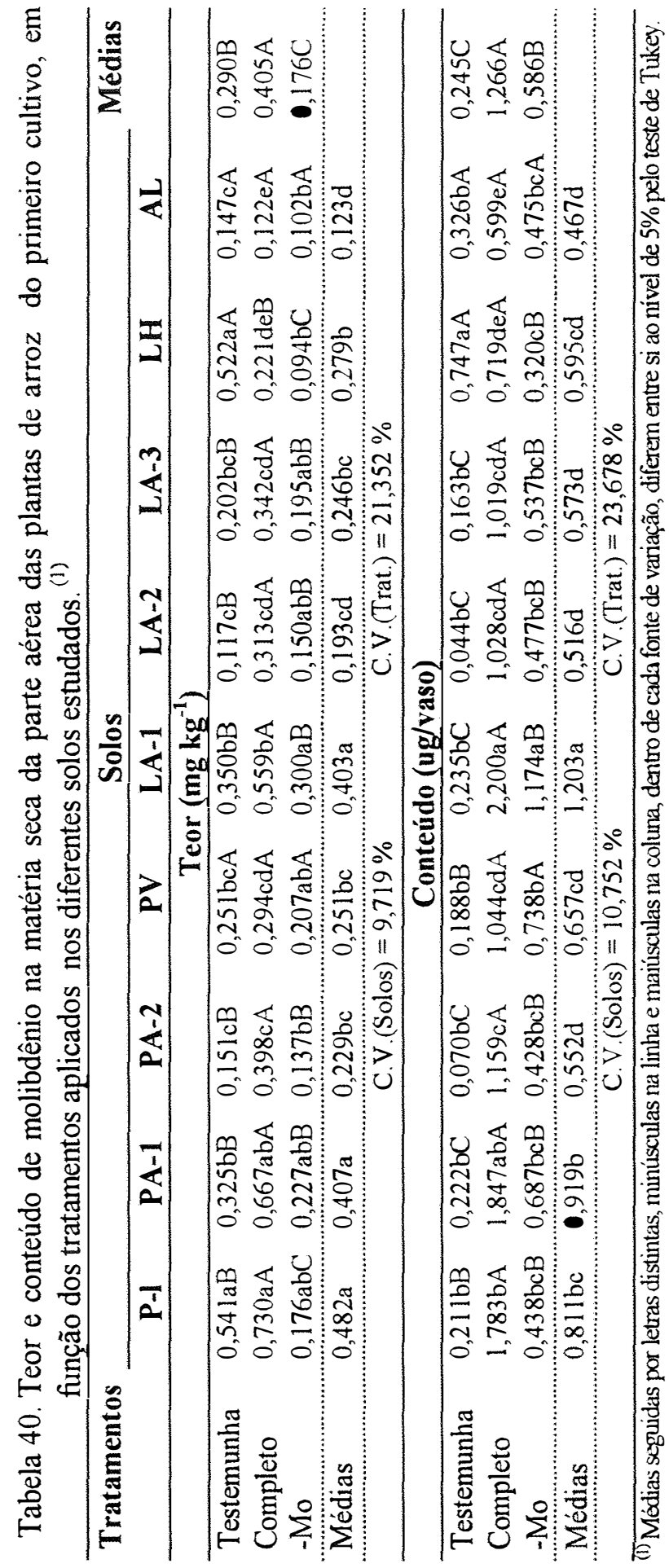




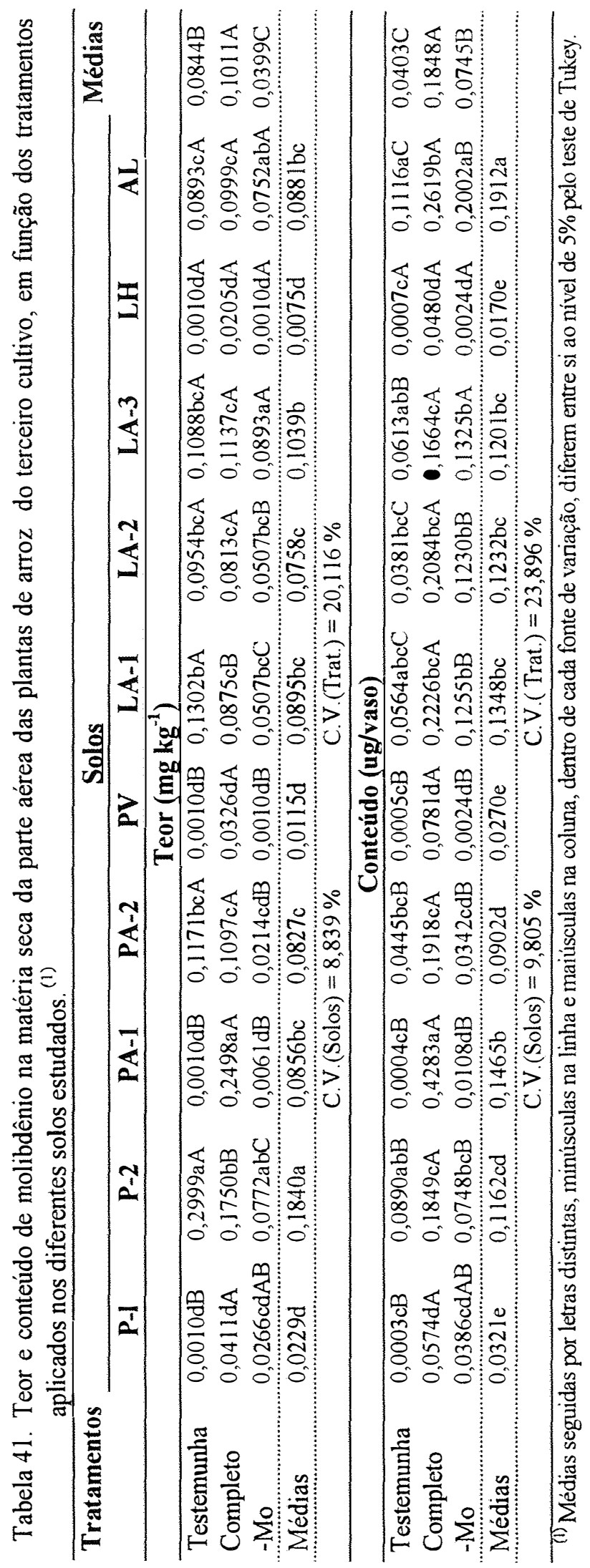




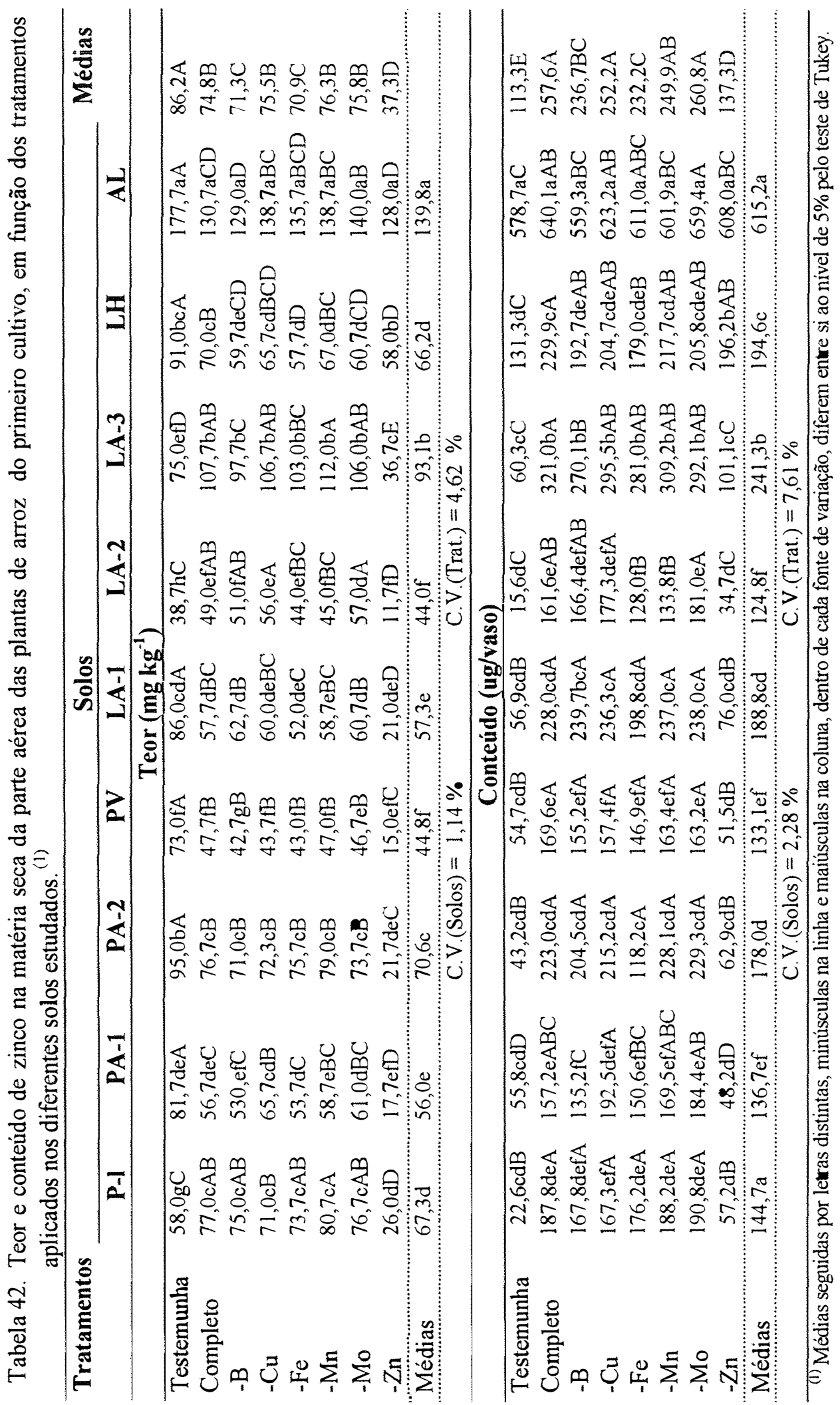




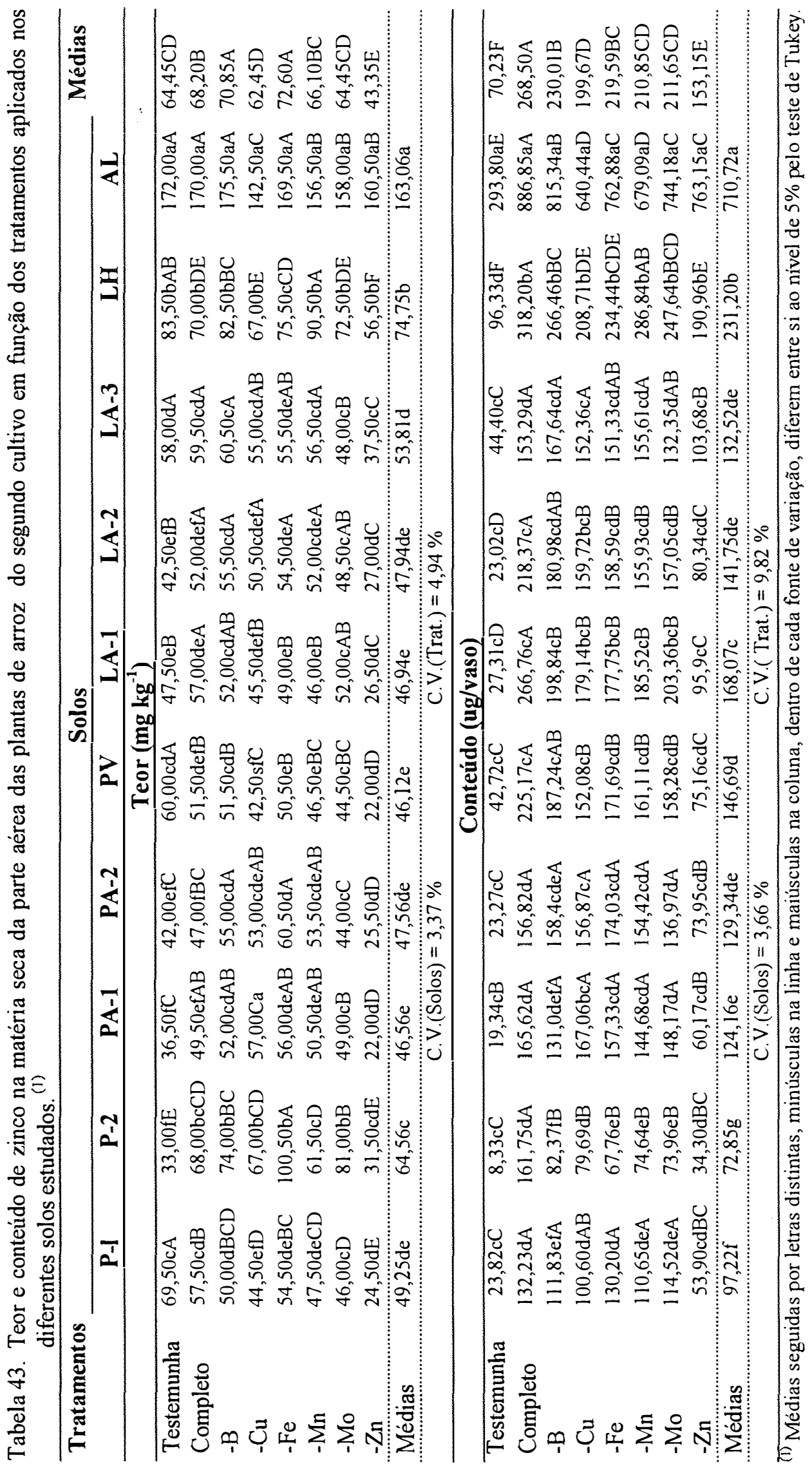




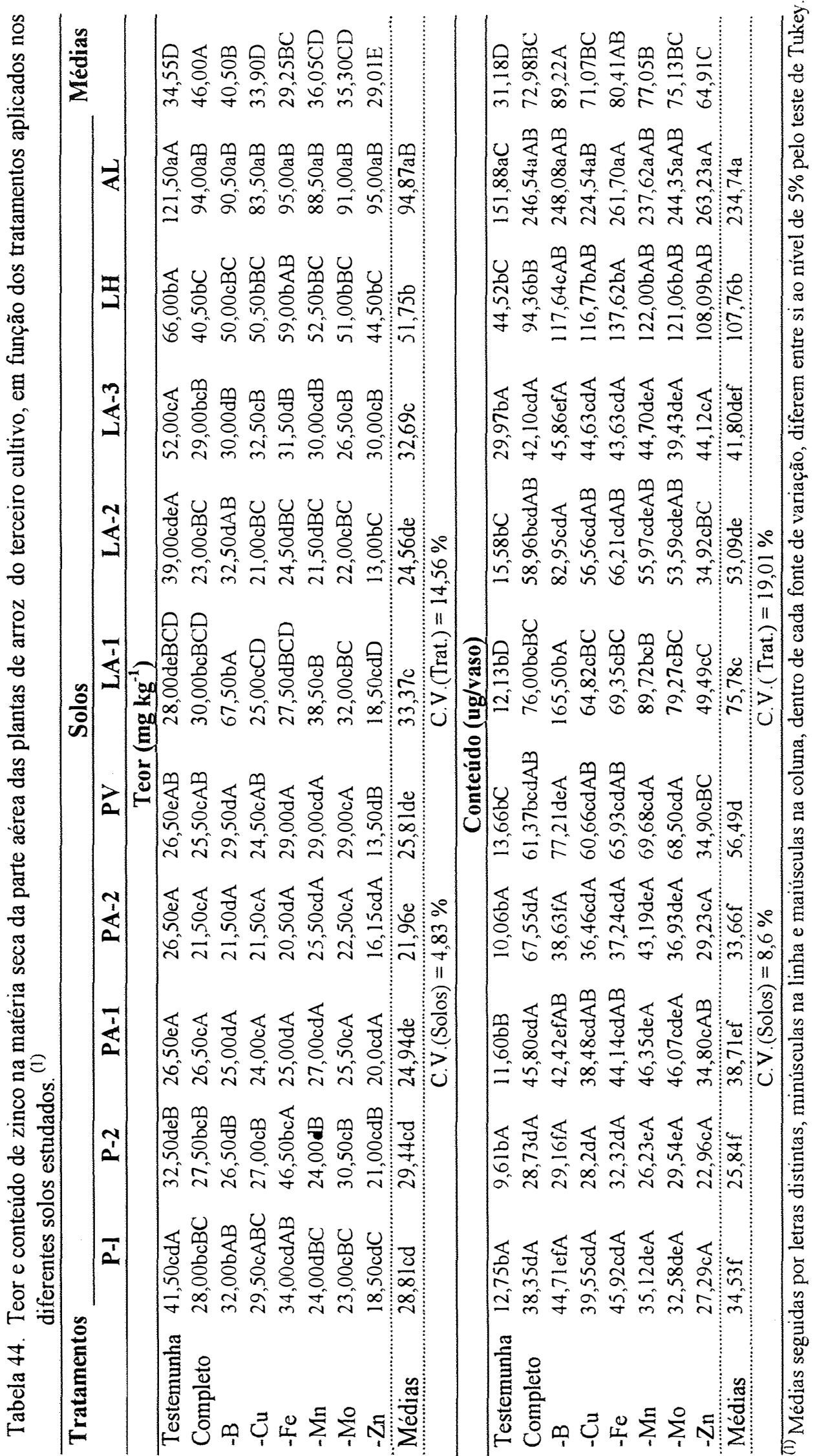


$\mathrm{Na}$ Tabela 45 encontram-se os valores de $\mathrm{pH}$ em $\mathrm{CaCl}_{2} \quad 0,01 \mathrm{~mol} \mathrm{~L}^{-1}$ determinados após a incubação do solo, antes do primeiro cultivo e após o terceiro cultivo do arroz. As análises das variâncias dos valores de $\mathrm{pH}$ obtidos após a incubação dos solos mostraram diferenças significativas entre os solos, os tratamentos e na interação solo $x$ tratamento. Percebe-se que a calagem teve o efeito previsto sobre a acidez dos solos, promovendo aumentos significativos de $\mathrm{pH}$ em relação à testemunha absoluta.

Os valores de $\mathrm{pH}$ obtidos após o terceiro cultivo evidenciam que, excluindo a testemunha absoluta, o cultivo sucessivo dos solos resultaram em marcantes diminuições dos valores médios dos mesmos, na ordem de quase duas unidades (Tabela 45).

\subsubsection{Macronutrientes}

O desenvolvimento de uma cultura é reflexo de vários fatores dentre os quais a disponibilidade de todos os nutrientes em quantidades suficientes é de fundamental importância. Buscando um melhor conhecimento dos equilíbrios entre os elementos químicos dos solos, determinou-se os teores disponiveis de fósforo, potássio, cálcio e magnésio através do extrator Mehlich 1 modificado pela EMBRAPA (1997). Esse método foi empregado como padrão de comparação para aferir o disponibilidade dos nutrientes, dada suas características de extrator multinutrientes e por ser o método adotado pelos laboratórios de solos da região Amazônica.

Os baixos teores disponiveis de fósforo na testemunha absoluta confirmam a pobreza química dos solos em relação a esse elemento (Tabelas 46, 47, 48 e 49). A resposta já esperada à aplicação do fósforo variou, principalmente, em função do teor de argila dos solos, evidenciando, assim, a maior capacidade dos solos argilosos em adsorver fósforo.

Os teores médios de fósforo variaram em função dos tratamentos aplicados. A literatura mostra que a adubação fosfatada pode reduzir a absorção do boro, cobre, ferro e zinco e por outro lado, aumentar a disponibilidade do manganês e do 
molibdênio (Olsen, 1972). Dentro desse contexto, chama à atenção os teores disponíveis de fósforo muito altos nos solos P-2, relacionados com a adubação fosfatada realizada junto com a calagem e com a baixa capacidade de adsorção de nutrientes dos solos arenosos (Tabela 46). As análises realizadas após cada cultivo (Tabelas 47, 48 e 49) acusaram teores acentuadamente menores, refletindo a absorção desse elemento pelas plantas. Também foi observado a interação $\mathrm{P} \times \mathrm{Fe}$; no tratamento com omissão de ferro foram observados teores de fósforo mais elevados. Corroboram esses resultados os teores de fósforo na MSPA significativamente maiores para o arroz cultivado nesses solos (Tabela 13), bem como a sintomatologia de deficiência de ferro observada nas plantas.

Na Tabela 50 são apresentados os teores de potássio obtidos pela solução extratora Mehlich 1 após a incubação dos solos, antes do primeiro cultivo. Teores significativamente inferiores foram observados para a testemunha absoluta, evidenciando a baixa capacidade dos solos em suprir as necessidades de potássio das plantas. Apenas o solo aluvial apresentou valores considerados médios.

O potássio é o nutriente mais absorvido pela planta de arroz (Barbosa Filho, 1987). Tal fato pode ser evidenciado pela diminuição acentuada dos teores médios de potássio disponíveis nos solos após cada cultivo (Tabelas 51, 52 e 53) comparados com àqueles obtidos após a incubação dos solos, antes do primeiro cultivo (Tabela 50).

A calagem elevou significativamente os teores disponíveis de cálcio nos solos (Tabela 54). Com exceção dos solos AL, LH e LA-3, os resultados obtidos antes do primeiro cultivo para a testemunha absoluta, evidenciaram teores muito baixos de cálcio. Observou-se uma tendência de teores médios de cálcio maiores no tratamento com omissão de boro (Tabelas 55, 56 e 57).

Comportamento semelhante ao cálcio foi observado para o magnésio na análise realizada após a incubação do solo, antes do primeiro cultivo (Tabela 58). Verificou-se, entretanto, que a disponibilidade do magnésio diminuiu acentuadamente do primeiro para o terceiro cultivo, reflexo do não fornecimento desse elemento pelas 
adubações de manutenção e consequente diminuição do efeito residual (Tabelas 58, 59, 60 e 61$)$.

\subsubsection{Micronutrientes}

Nas Tabelas 62, 63, 64 e 65 são apresentados os teores disponiveis de boro obtidos pela solução extratora Mehlich 1 e nas Tabelas 66, 67, 68 e 69 os teores disponíveis de boro obtidos pela solução extratora água quente nas determinações realizadas após a incubação dos solos, antes do primento cultivo e depois do primeiro, segundo e terceiro cultivo. Os resultados mostram que a aplicação de boro nos solos teve o efeito esperado, provocando aumentos significativos nos teores disponíveis desse

elemento (Tabelas 62 e 66). Tanto para o extrator Mehlich 1 quanto para água quente observou-se que a disponibilidade do boro diminuiu acentuadamente do primeiro para o terceiro cultivo.

Observou-se também para ambos os extratores que os teores médios de boro variaram em função dos tratamentos aplicados e para os diferentes solos estudados. Em todas as determinações, os menores teores observados estiveram sempre associados ao tratamento com omissão do elemento. Resultados semelhantes foram obtidos por Ribeiro \& Tucunango Sarabia (1984) nos estudos de avaliação de extratores para boro disponivel em latossolos do Triângulo Mineiro.

Os estudos de avaliação para boro disponivel no solo mostram que o extrator Mehlich 1 é capaz de solubilizar quantidades de boro maiores do que as extraídas pela água quente (Ribeiro \& Tucunango Sarabia, 1984; Shuman et al., 1992; Paula et al., 1995). Entretanto, nesse trabalho, os resultados obtidos não evidenciaram esse efeito (Tabelas 62, 63, 64 e 65 para Mehlich 1 e Tabelas 66, 67, 68 e 69 para água quente).

A determinação do boro disponivel nos diferentes solos estudados seguiu a metodologia preconizada por Abreu et al. (1996) e os teores obtidos após a incubação do solo (Tabela 66) ficaram entre aqueles observados pelos autores em treze solos do Estado de São Paulo. Em seu estudo mundial sobre a disponibilidade dos micronutrientes 


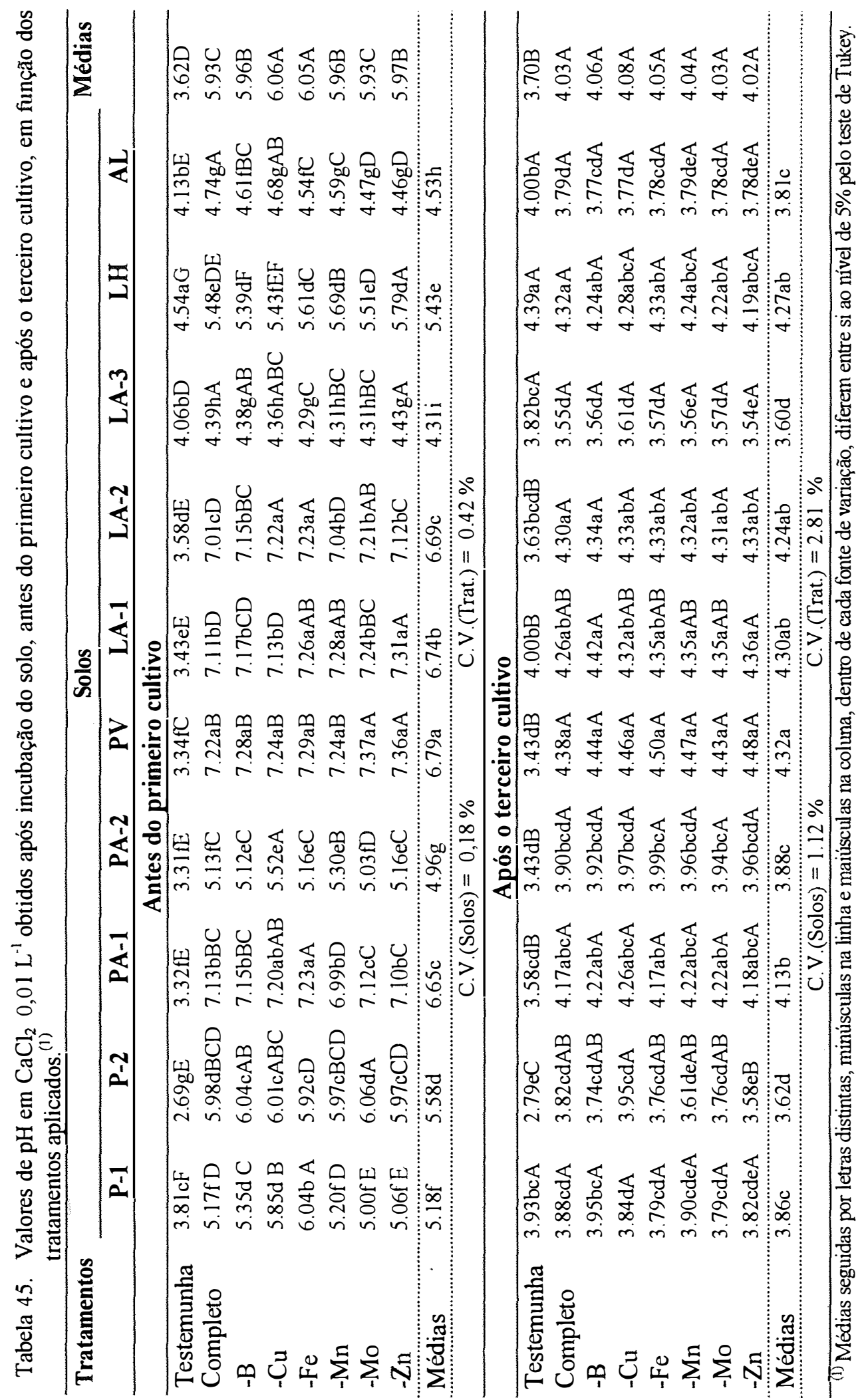



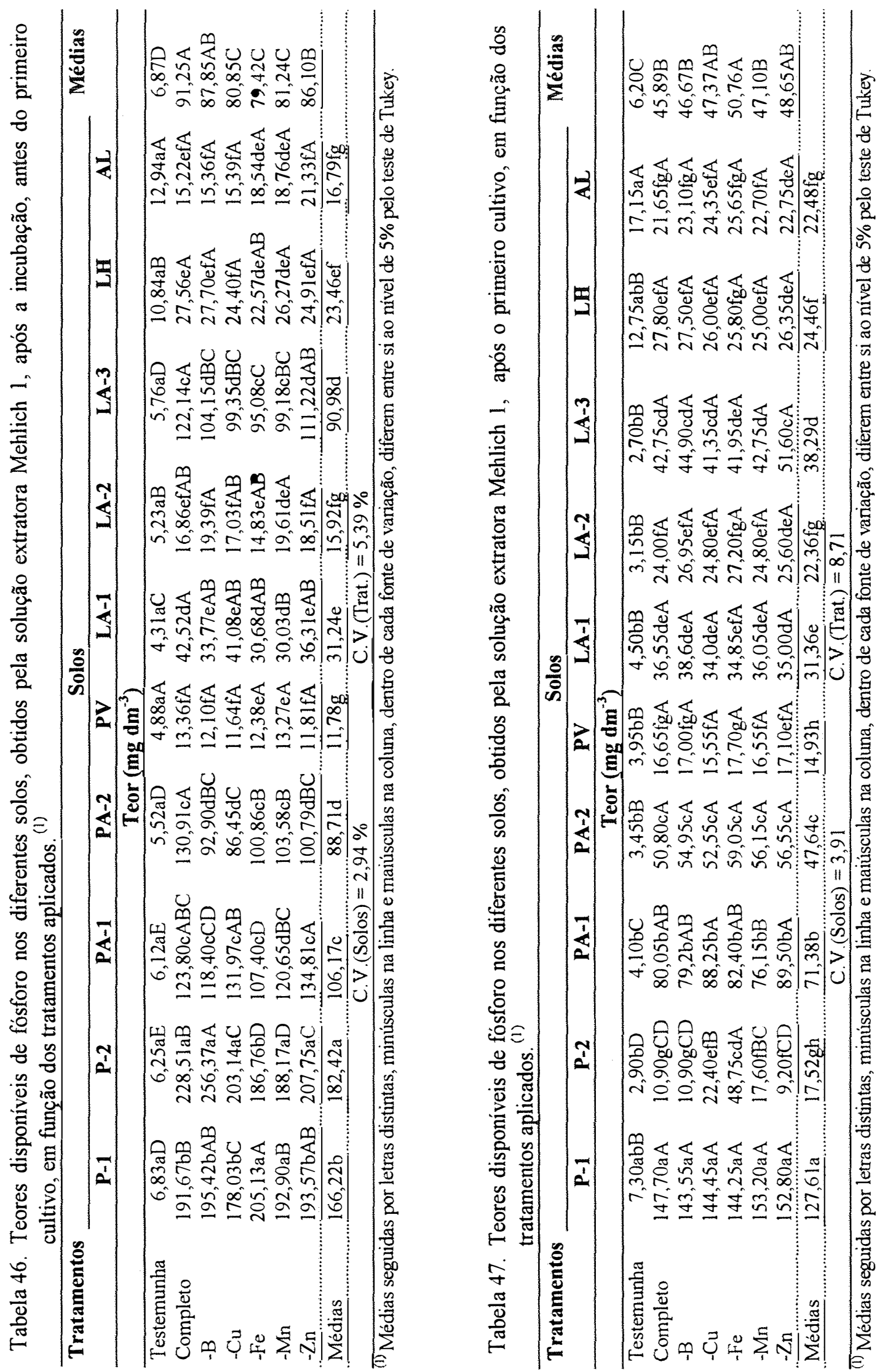


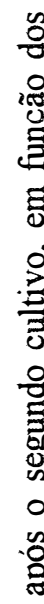

is

(5)

ำ

$\frac{1}{2}$

:

की

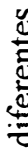

o

:

诘=

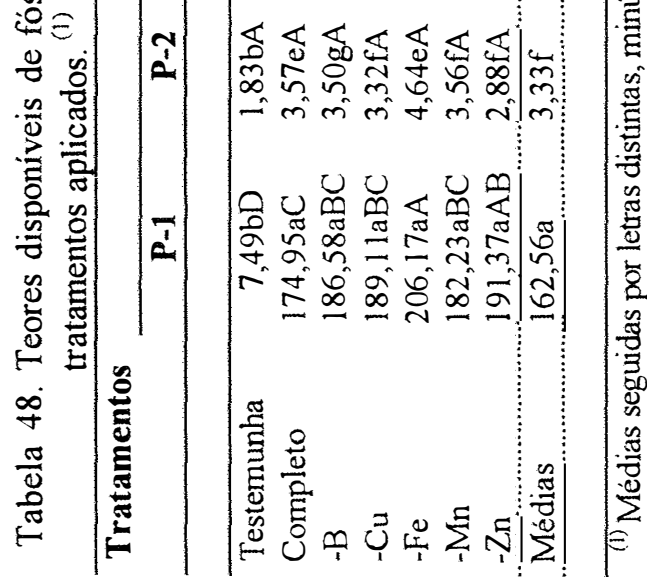

育 |

年

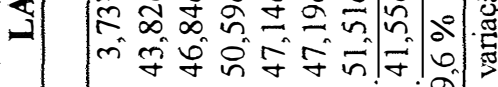

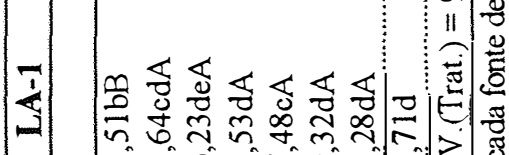

\% m

ㅇํํ Z

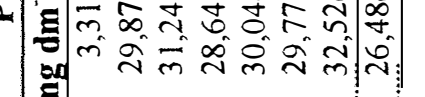
을

产

신

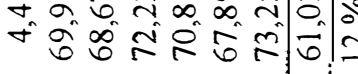

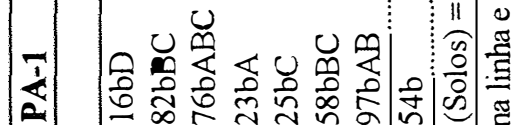

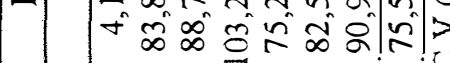
0 告

鱼

竎

$\frac{5}{5}$

迩

$\frac{5}{8}$

营

:

$\sum$

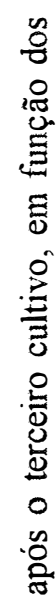



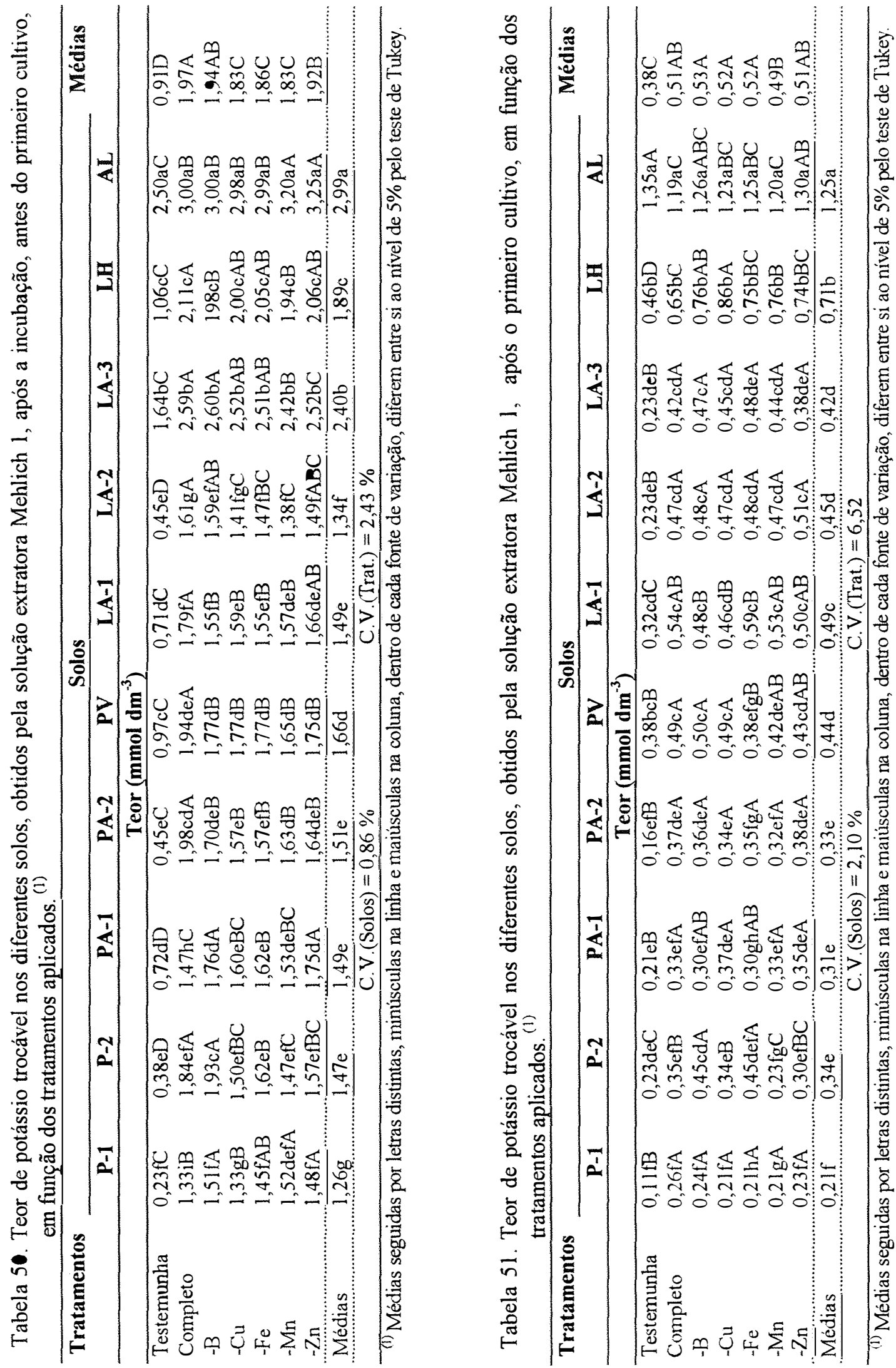

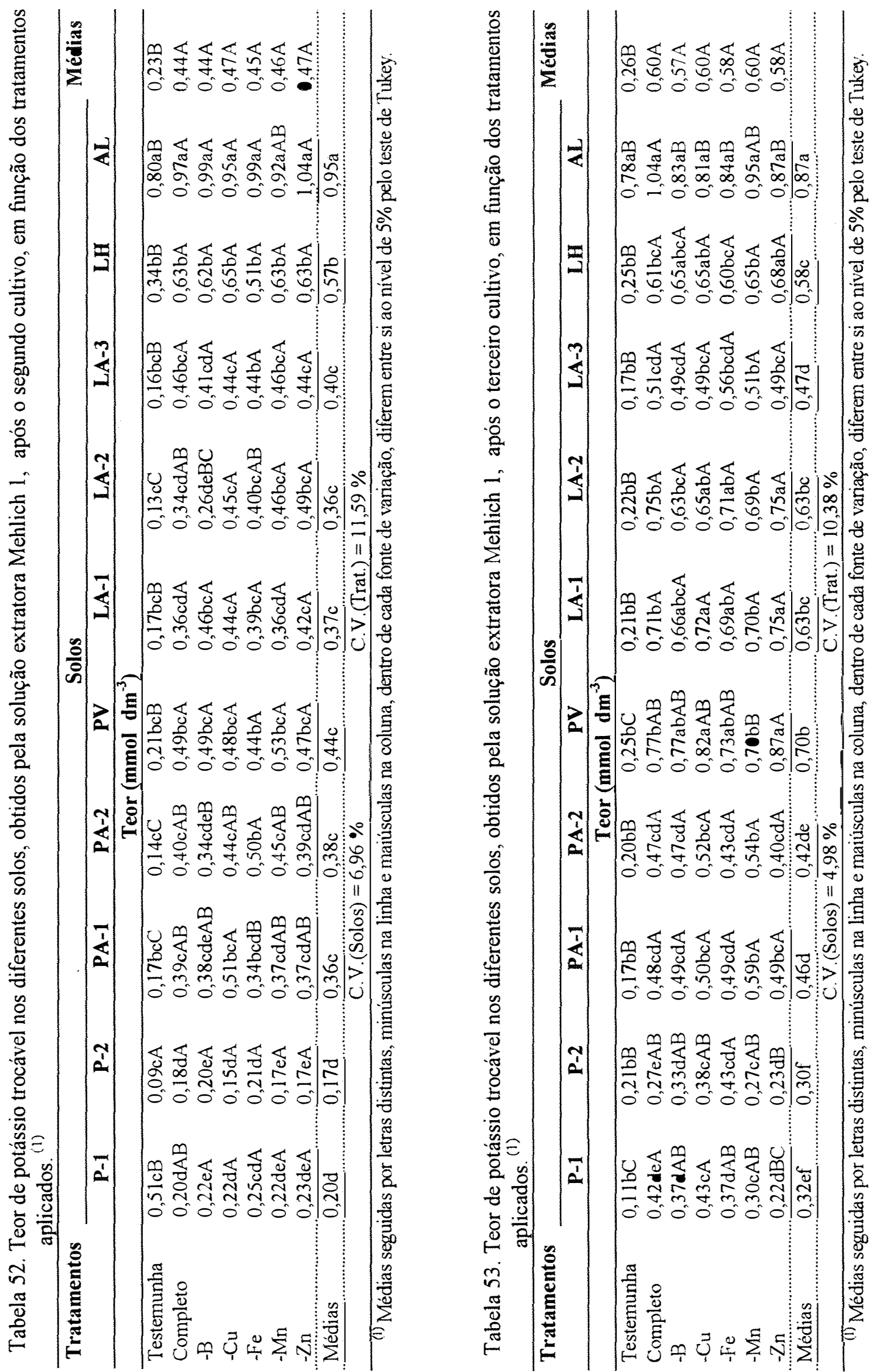

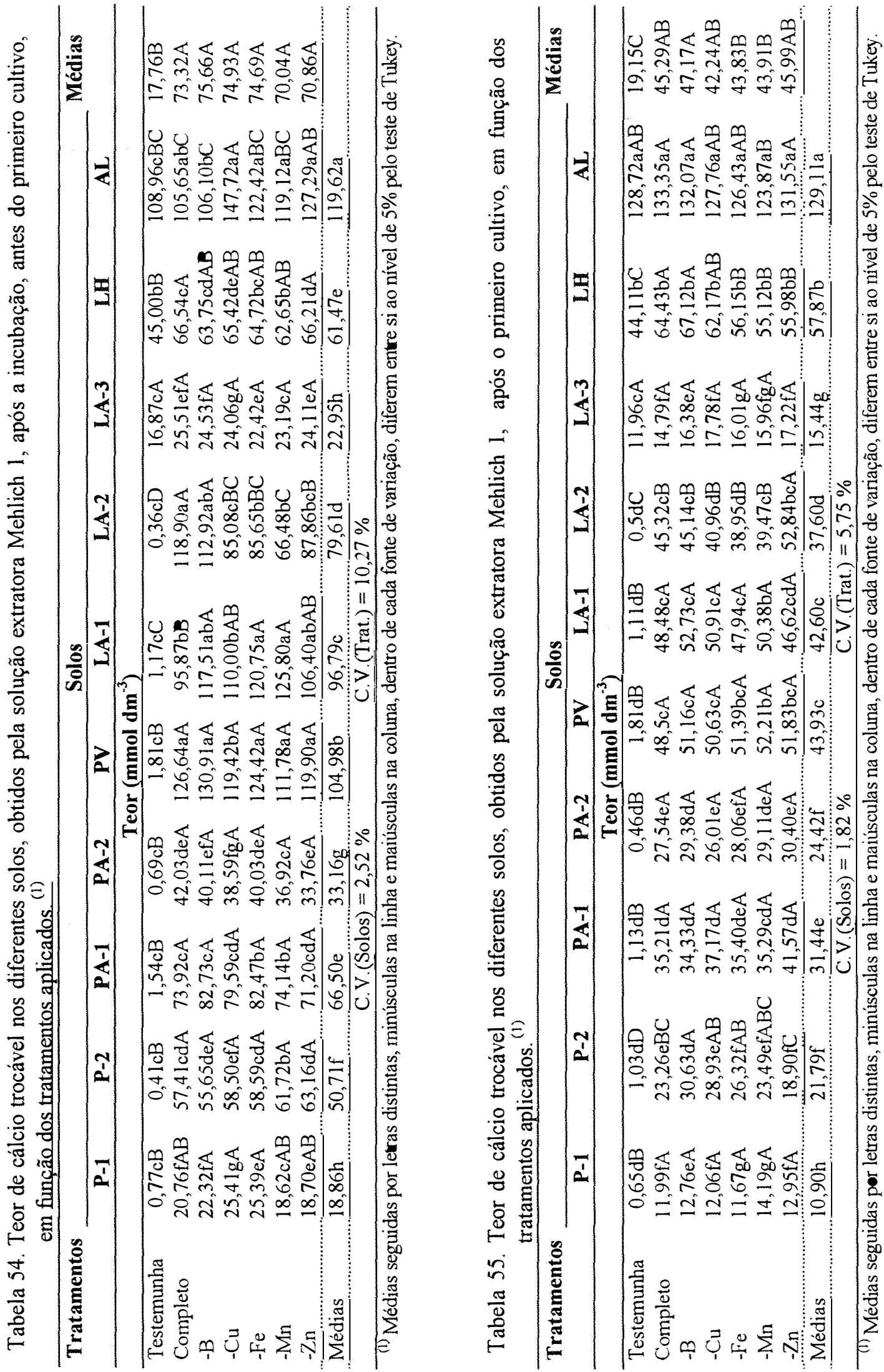

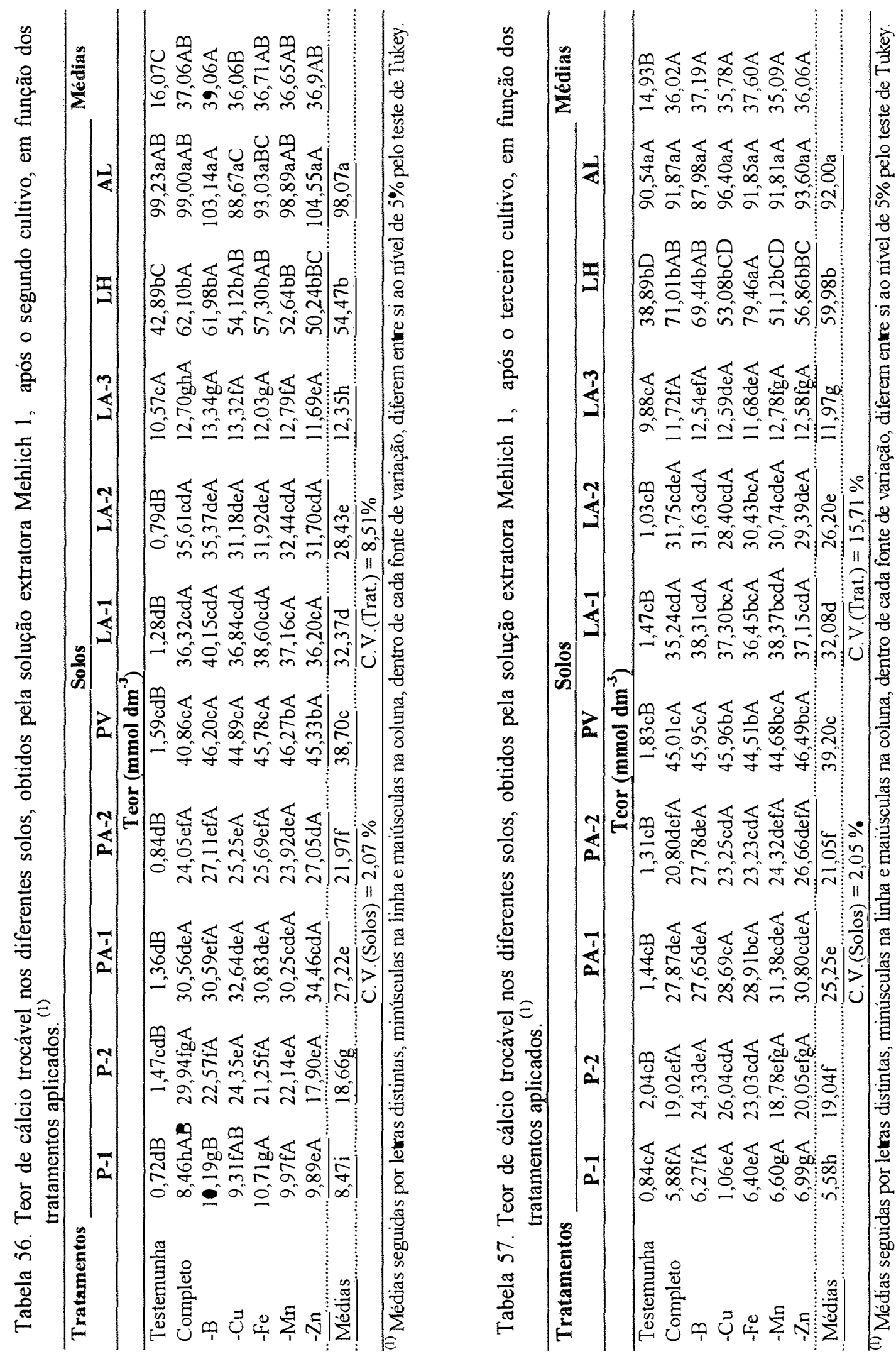

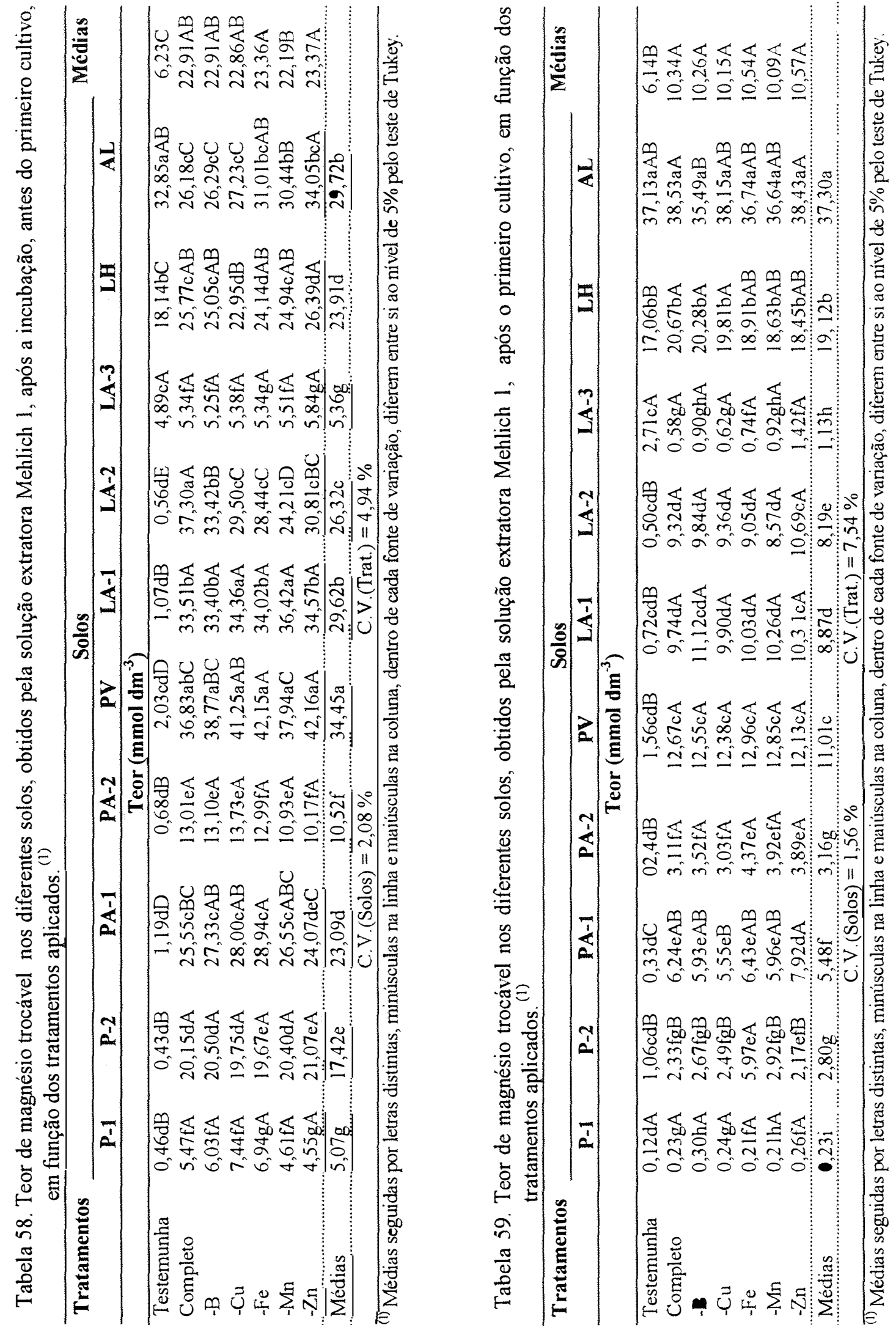

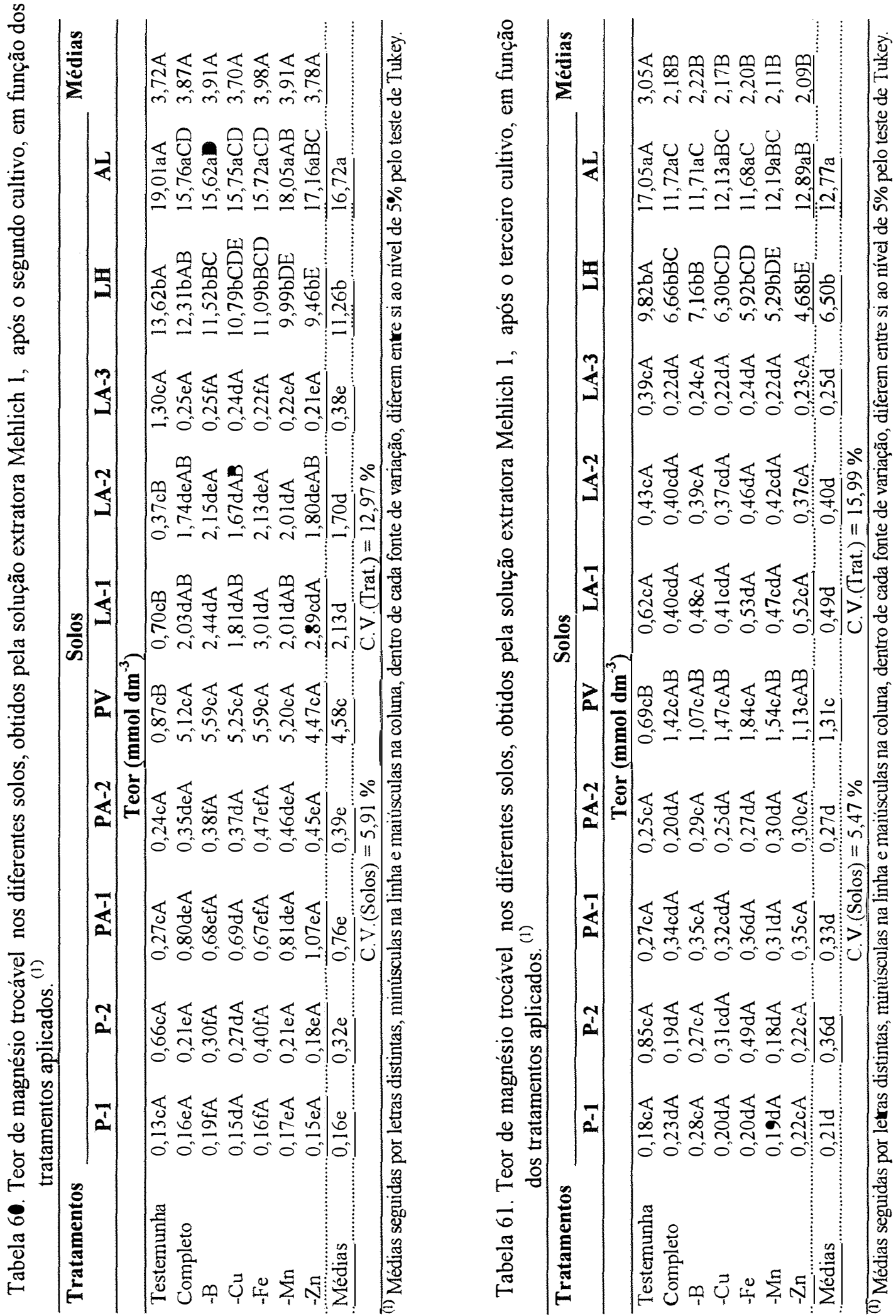
nos solos, Sillanpãã (1982) determinou o teor de boro em 58 amostras de solos brasileiros pelo método da água quente; concluiu que os teores obtidos estavam dentro da faixa normal (média geral de $0,64 \mathrm{mg} \mathrm{dm}^{-3}$ ).

Nas Tabelas 70, 71, 72 e 73 são apresentados, sequencialmente, os teores de cobre disponiveis obtidos pela solução extratora Mehlich 1 após a incubação dos solos, antes do primeiro cultivo e após o primeiro, o segundo e o terceiro cultivo; nas Tabelas 74, 75, 76 e 77, pela solução extratora Mehlich 3; nas Tabelas 78, 79, 80 e 81, pela solução extratora DTPA-TEA pH 7,3. Para os três extratores, na ausência da aplicação do cobre (testemunha absoluta e tratamento com omissão de $\mathrm{Cu}$ ), foram observados teores significativamente inferiores (Tabelas 70, 74 e 78). Por outro lado, teores disponíveis de cobre considerados altos foram observados para o solo aluvial, médios a baixos para o solo LH e muito baixos para os demais solos, dependendo do extrator (Viets \& lindsay, 1973; Lopes \& Cox, 1977; Mehlich, 1984). Resultados semeLHntes foram encontrados por Singh (1984b) em seus estudos sobre a disponibilidade de micronutrientes em seis classes de solos dominantes do trópico úmido brasileiro, exceto para o solo aluvial. Esse resultado conflitante observado para o solo aluvial pode ser, em parte, explicado pela diferença no teor total de cobre; o autor obteve apenas $1,61 \mathrm{mg} \mathrm{kg}^{-1}$ de $\mathrm{Cu}$ total contra $28 \mathrm{mg} \mathrm{kg}^{-1}$ obtidos no aluvial em estudo.

Apesar dos baixos teores disponíveis de cobre observados na maioria dos solos estudados, esse elemento não afetou significativamente a produção de matéria seca do arroz e os teores obtidos na MSPA atingiram niveis considerados adequados por Barbosa Filho (1987). Do mesmo modo, trabalhos desenvolvidos em solos de cerrado para a cultura do milho (Britto et al., 1971) e para a cultura do milho e do arroz, utilizando a técnica de diagnóstico por subtração (Galrão \& Mesquita Filho, 1981), não mostraram qualquer efeito detrimental da omissão de cobre, mesmo para solos que apresentavam menos de $1 \mathrm{mg} \mathrm{dm}{ }^{-3}$ de $\mathrm{Cu}$ disponível pelo extrator Mehlich 1 . Em um outro estudo desenvolvido por Barbosa Filho et al.(1990) nas mesmas condições de solo e extrator, não ficou caracterizada uma resposta direta do arroz e do milho ao cobre. 
Nas Tabelas 82, 83, 84 e 85 são apresentados, sequencialmente, os teores de ferro disponíveis obtidos pela solução extratora Mehlich 1 após a incubação dos solos, antes do primeiro cultivo e após o primeiro, o segundo e o terceiro cultivo; nas Tabelas 86, 87, 88 e 89, pela solução extratora Mehlich 3; nas Tabelas 90, 91, 92 e 93, pela solução extratora DTPA-TEA pH 7,3. De um modo geral, independentemente do extrator utilizado, os menores teores disponíveis de ferro foram obtidos nos solos podzois e no latossolo húmico antropogênico, enquanto que o maior ocorreu no solo aluvial, onde o teor disponível de ferro atingiu o dobro do maior teor observado nos demais solos (Tabelas 82, 86 e 90).

Os teores de ferro disponíveis obtidos na testemunha absoluta, utilizando o extrator Mehlich 1, variaram de 11 (LH e P-2) a $629 \mathrm{mg} \mathrm{dm}^{-3}$ (AL). Esses teores são muito elevados comparados àqueles observados por Lopes (1983) em amostras de solos de cerrado utilizando o mesmo extrator, cujos os valores variaram de 4 a $74 \mathrm{mg} \mathrm{dm}^{-3}$ com uma mediana de 32. Por outro lado, estão de acordo com os resultados obtidos por Singh (1984c) em solos semelhantes da região Amazônica, que encontrou teores disponíveis de ferro variando de 10 (LV) a $1112 \mathrm{mg} \mathrm{dm}^{-3}$ (GPH) pelo extrator Mehlich 1.

Em geral, segundo Barbosa Filho (1991), as concentrações de ferro acima de $350 \mathrm{mg} \mathrm{dm}^{-3}$ na solução do solo são consideradas tóxicas para o arroz; entretanto, nesse trabalho foi verificado o dobro desse valor para o solo AL sem qualquer efeito detrimental para as plantas. Observou-se ainda para esse solo, uma diminuição gradativa dos teores de ferro determinados pelos extratores Mehlich 1 e DTPA, que atingiu no terceiro cultivo metade do valor obtido no solos antes de ser cultivado, indicando a absorção desse elemento pelas plantas de arroz (Tabelas 82, 83, 84 e 85 para Mehlich 1 e Tabelas 90, 91, 92 e 93 para DTPA).

Nas Tabelas 94, 95, 96 e 97 são apresentados, sequencialmente, os teores de manganês disponíveis obtidos pela solução extratora Mehlich 1 após a incubação dos solos, antes do primeiro cultivo e após o primeiro, o segundo e o terceiro cultivo; nas Tabelas 98, 99, 100 e 101 pela solução extratora Mehlich 3; nas Tabelas 102, 103, 104 e 105, pela solução extratora DTPA-TEA pH 7,3. De um modo geral, independentemente 
do extrator utilizado, os teores disponiveis de manganês obtidos na testemunha absoluta dos diferentes solos variaram de $0,23 \mathrm{mg} \mathrm{kg}^{-1}$ (DTPA) a $244 \mathrm{mg} \mathrm{dm}^{-3}$ (Mehlich 1) obedecendo a seguinte sequência: $\mathrm{AL}>\mathrm{LH}>\mathrm{LA}-3>\mathrm{PV}>$ LA-1 $>$ PA-1 $>$ P-1 $>$ LA-2 $>$ PA-2 $>$ P2 (Tabelas 94, 98 e 102). Observa-se, portanto, que os latossolos amarelos, os podzólicos e os podzois são, em geral, deficientes em manganês disponivel às plantas, considerando-se o nível crítico de $5 \mathrm{mg} \mathrm{kg}^{-1}$ para os extratores DTPA e Mehlich 1 (Lindsay \& Cox, 1985). Resultados semelhantes foram obtidos por Singh (1984a) estudando a disponibilidade de manganês, utilizando vários extratores, em diferentes solos da Amazônia. Os teores disponíveis de Mn obtidos pelo autor variaram de 0,37 mg $\mathrm{kg}^{-1}$ (DTPA para a média dos LA) a $884 \mathrm{mg} \mathrm{kg}^{-1}$ (EDT A para a média das TE).

Independentemente do extrator utilizado e dos tratamentos aplicados, os teores disponíveis de Mn nos diferentes solos diminuíram acentuadamente do primeiro para o terceiro cultivo. Esses resultados sugerem, para a grande maioria dos solos da Amazônia, a possibilidade do aparecimento de deficiências de Mn pelo uso continuado dos mesmos, a curto prazo, dependendo da cultura.

A Tabela 106 mostra os teores disponíveis de molibdênio obtidos após a incubação dos solos e a Tabela 107 após o terceiro cultivo, pela solução extratora ABDTPA. De modo geral, com exceção dos solos P-2 e LA-3, os teores disponíveis de Mo na testemunha absoluta foram semelhantes ou um pouco superiores aos observados nos demais tratamentos onde o elemento foi aplicado (Tabela 106). Esse resultado pode estar relacionado aos teores adequados de matéria orgânica desses solos. Estudos desenvolvidos por Karimian \& Cox (1978) sobre adsorção e extração de Mo em relação a algumas propriedades químicas do solo mostram que, um teor elevado em matéria orgânica pode, até um certo ponto, diminuir os riscos de deficiência de Mo na presença de um baixo $\mathrm{pH}$; pois, segundo os autores, o nível de Mo adsorvido está estreitamente relacionado à matéria orgânica do solo. Um outro aspecto a ser considerado, são as interações que podem ter ocorrido entre os nutrientes no tratamento completo. A análise realizada após a incubação dos solos mostrou na ausência da aplicação de cobre, que os teores disponíveis de Mo diminuíram significativamente em relação ao tratamento 
completo e à testemunha absoluta (Tabela 106). O antagonismo entre $\mathrm{Cu}$ e Mo foi estudado por MacKay et al.(1966) sobre várias espécies; os autores concluíram que a toxicidade de um elemento poderia ser diminuída pelo fornecimento do outro.

Nas Tabelas 108, 109, 110 e 111 são apresentados, sequencialmente, os teores de zinco disponíveis obtidos pela solução extratora Mehlich 1 após a incubação dos solos, antes do primeiro cultivo e após o primeiro, o segundo e o terceiro cultivo; nas Tabelas 112, 113, 114 e 115, pela solução extratora Mehlich 3; nas Tabelas 116, 117, 118 e 119, pela solução extratora DTPA-TEA pH 7,3. O solo aluvial, independentemente do extrator utilizado, apresentou teores disponiveis de $\mathrm{Zn}$ estatisticamente superiores aos demais solos. Paula et al. (1991), avaliando a disponibilidade do zinco em solos de várzea cultivados com arroz através de vários extratores, obtiveram para um solo aluvial 7,20 $\mathrm{mg} \mathrm{dm}{ }^{-3}$ de $\mathrm{Zn}$ disponível pelo extrator Mehlich 1 . Os autores definiram que o nível crítico de zinco no solo de várzea para o arroz, utilizando esse extrator, seria de $2,1 \mathrm{mg}$ $\mathrm{dm}^{-3}$.

Nas Tabelas 108, 109, 110 e 111 são apresentados, sequencialmente, os teores de zinco disponíveis obtidos pela solução extratora Mehlich 1 após a incubação dos solos, antes do primeiro cultivo e após o primeiro, o segundo e o terceiro cultivo; nas Tabelas 112, 113, 114 e 115, pela solução extratora Mehlich 3; nas Tabelas 116, 117 , 118 e 119, pela solução extratora DTPA-TEA pH 7,3. O solo aluvial, independentemente do extrator utilizado, apresentou teores disponiveis de $\mathrm{Zn}$ estatisticamente superiores aos demais solos. Corroboram esses resultados as observações de Corrêa \& Bastos (1982) sobre a não ocorrência de deficiência de zinco nos solos de várzea do Estado do Amazonas. Paula et al. (1991), avaliando a disponibilidade do zinco em solos de várzea cultivados com arroz através de vários extratores, obtiveram para um solo aluvial 7,20 $\mathrm{mg} \mathrm{dm}{ }^{-3}$ de $\mathrm{Zn}$ disponível pelo extrator Mehlich 1 . Os autores definiram que o nível crítico de zinco no solo de várzea para o arroz, utilizando esse extrator, seria de $2,1 \mathrm{mg}$ $\mathrm{dm}^{-3}$.

Os teores disponiveis de $\mathrm{Zn}$ na testemunha absoluta, considerando os três extratores (Tabelas 108, 112 e 116), variaram de $0,06 \mathrm{mg} \mathrm{kg}^{-1}$ (DTPA) a 8,86 $\mathrm{mg} \mathrm{dm}^{-3}$ 
(Mehlich 1), obedecendo a seguinte ordem: podzois $<$ podzólicos $<$ latossolos amarelos $<$ latossolo húmico $<$ aluvial. Resultados semelhantes foram obtidos por Singh \& Möller (1984) nos latossolos e podzólicos da Amazônia.

De modo geral, os teores disponiveis de $\mathrm{Zn}$ na testemunha absoluta estão abaixo da faixa média de concentração proposta para os solos do Estado de São Paulo obtidos pelo extrator DTPA (Raij et al., 1996), exceto nos solos AL e LH. Para um latossolo vermelho-amarelo argiloso de cerrado cultivado com milho, Galrão (1995) definiu que o nível crítico do zinco seria para o extrator $\mathrm{HCl} 0,1 \mathrm{~mol} \mathrm{~L}^{-1}=0,9 \mathrm{mg} \mathrm{dm}^{-3}$, Mehlich $1=0,7 \mathrm{mg} \mathrm{dm}^{-3}$ e DTPA=0,4 $\mathrm{mg} \mathrm{dm}^{-3}$. Os níveis críticos definidos por esse autor são menores do que aqueles, em geral, citados na literatura (Lopes, 1975; Ritchey et al., 1986; Raij et al., 1996). Os teores disponíveis de $\mathrm{Zn}$ obtidos em solos minerais pelo extrator Mehlich 3 foram definidos por Junus \& Cox (1987) como sendo: 1,62 $\mathrm{mg} \mathrm{dm}^{-3}$ para a soja e $1,53 \mathrm{mg} \mathrm{dm}^{-3}$ para o milho.

Os tratamentos que não receberam zinco foram significativamente inferiores aos demais. O cultivo sucessivo dos solos acentuou a deficiência de $\mathrm{Zn}$ nos mesmos.

\subsection{Comportamento das soluções extratoras nas determinações de $\mathrm{Cu}, \mathrm{Fe}, \mathrm{Mn}$ e $\mathrm{Zn}$.}

Os resultados da Tabela 120 demonstram a grande variabilidade dos teores de $\mathrm{Cu}, \mathrm{Fe}, \mathrm{Mn}$ e $\mathrm{Zn}$ encontrados nos diferentes solos estudados, obtidos pelos extratores Mehlich 1, Mehlich 3 e DTPA. Os teores de cobre obtidos pelos extratores Mehlich 1 e DTPA foram semelhantes, considerando-se os teores máximos e mínimos do elemento no solo. O extrator Mehlich 3 foi o que apresentou menor eficiência na discriminação das variações na concentração desse elemento nos diferentes solos, provenientes dos tratamentos aplicados e da grande variabilidade nas características físicas e químicas dos mesmos, já mostradas nas Tabelas 3,5 e 6 . Esse resultado é corroborado pelos coeficientes de correlação significativos e maiores entre o teor disponível de cobre no solo obtidos pelos extratores Mehlich 1 e DTPA e seu teor e conteúdo na MSPA do primeiro cultivo (Tabela 122). Resultados semelhantes foram obtidos por Bataglia \& Raij (1989). 

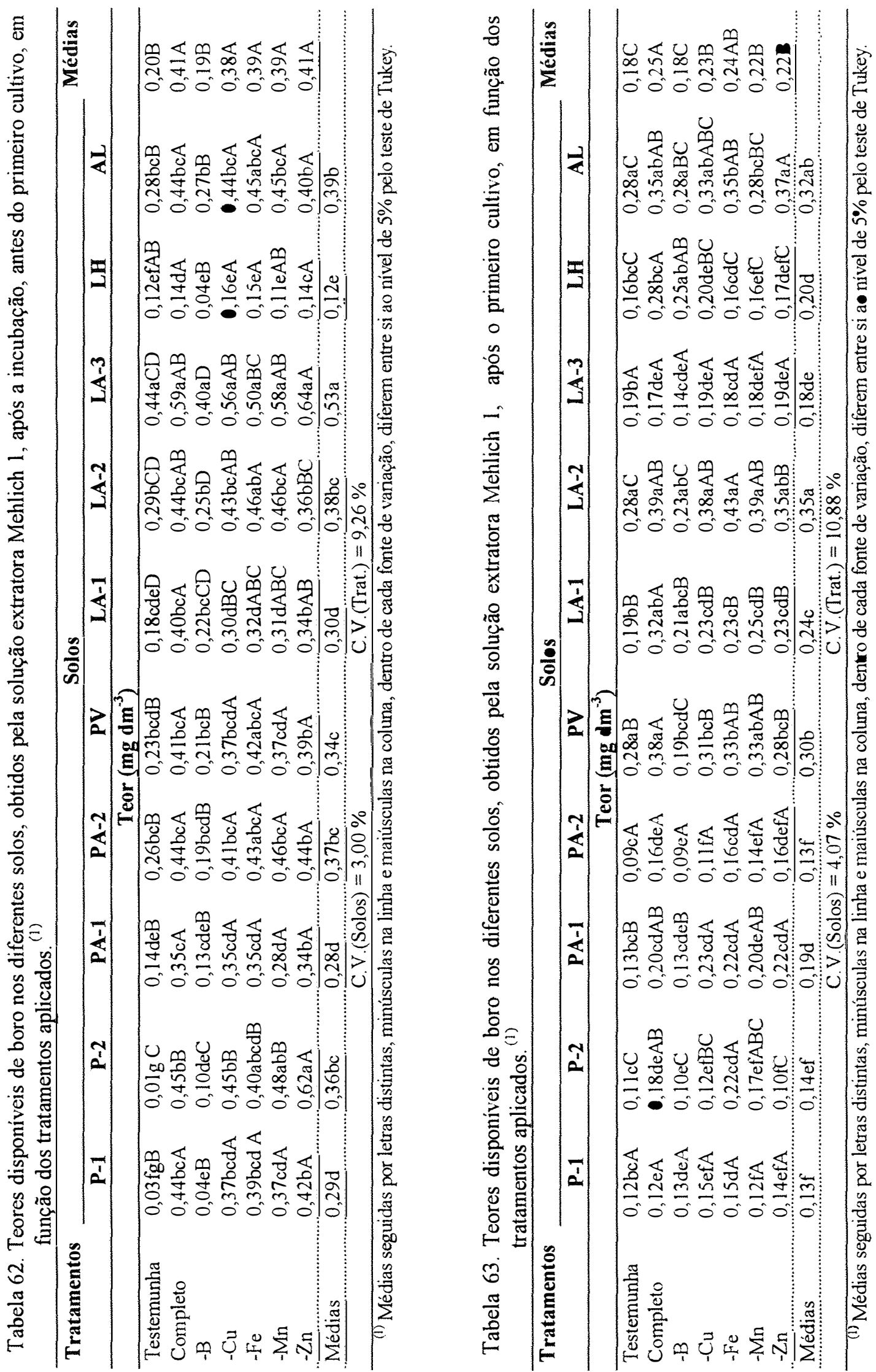

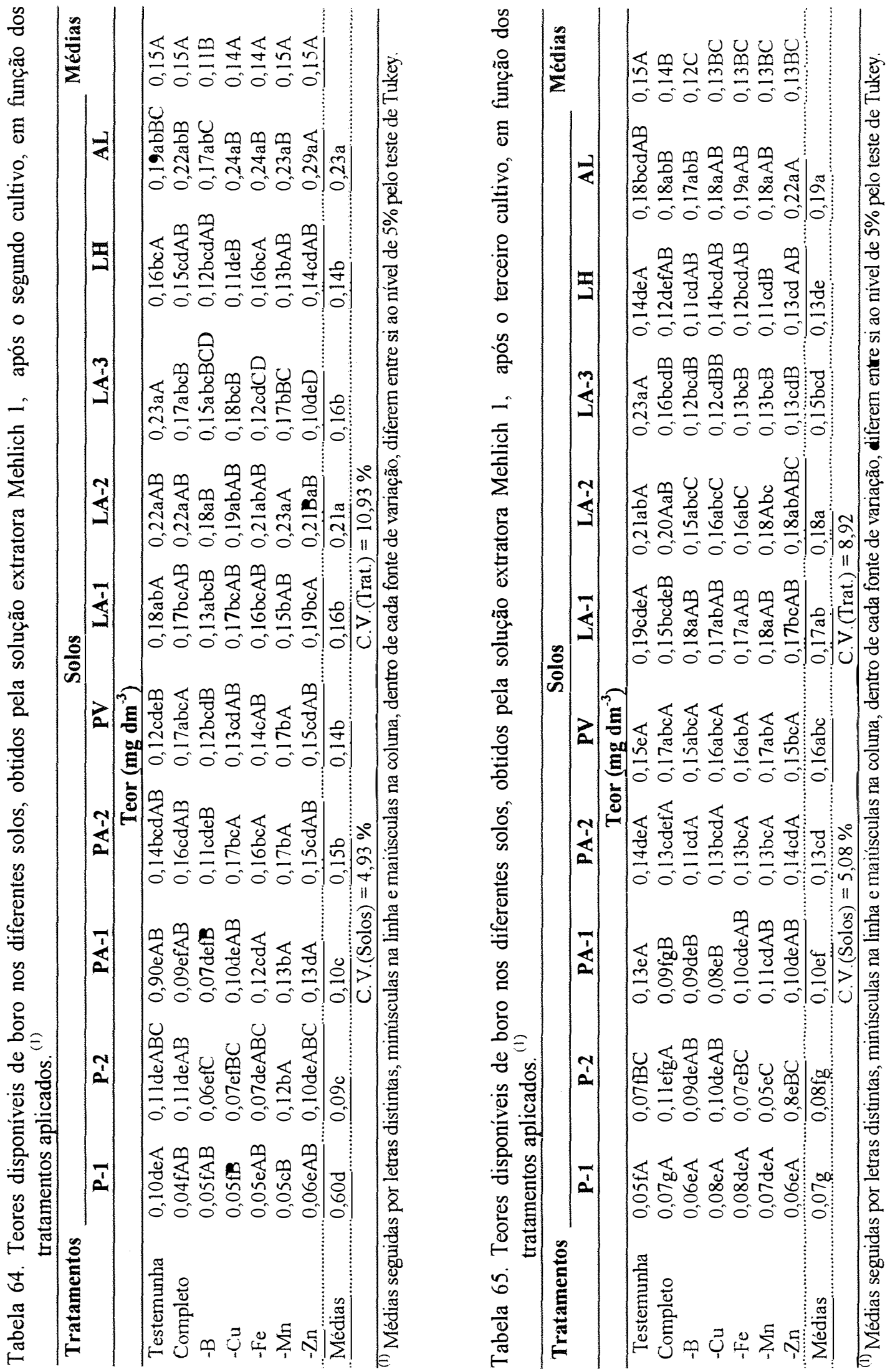

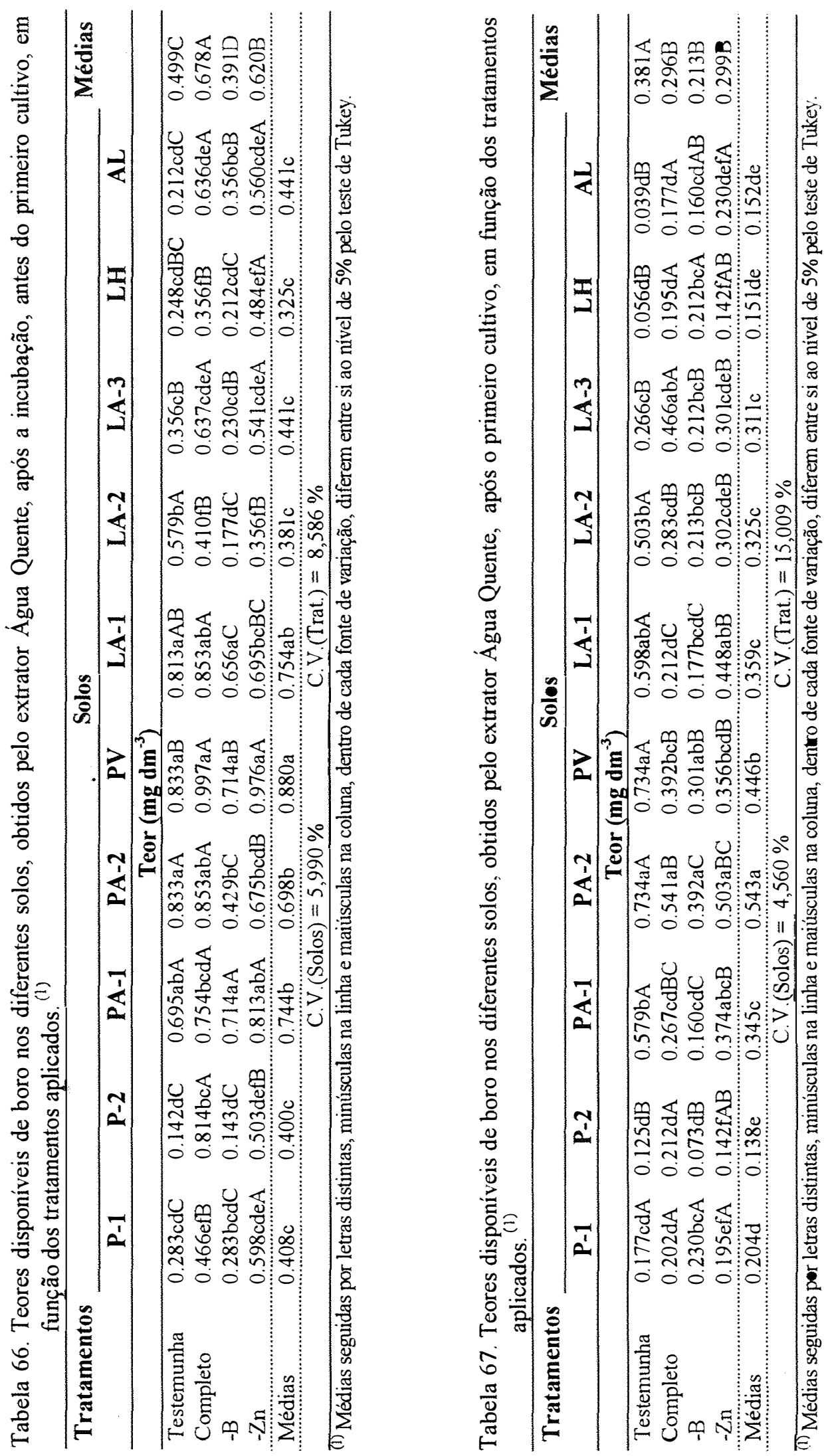

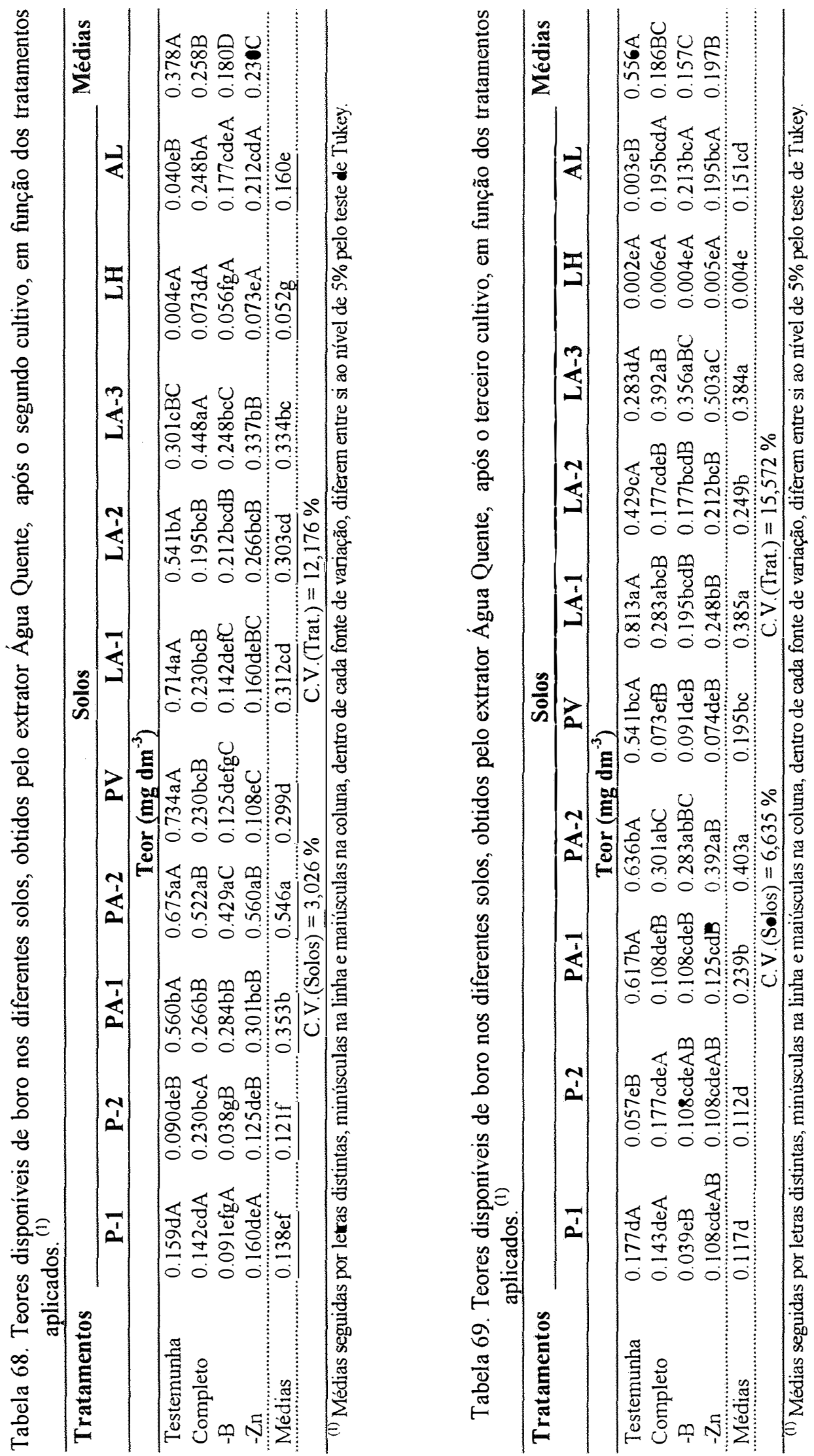

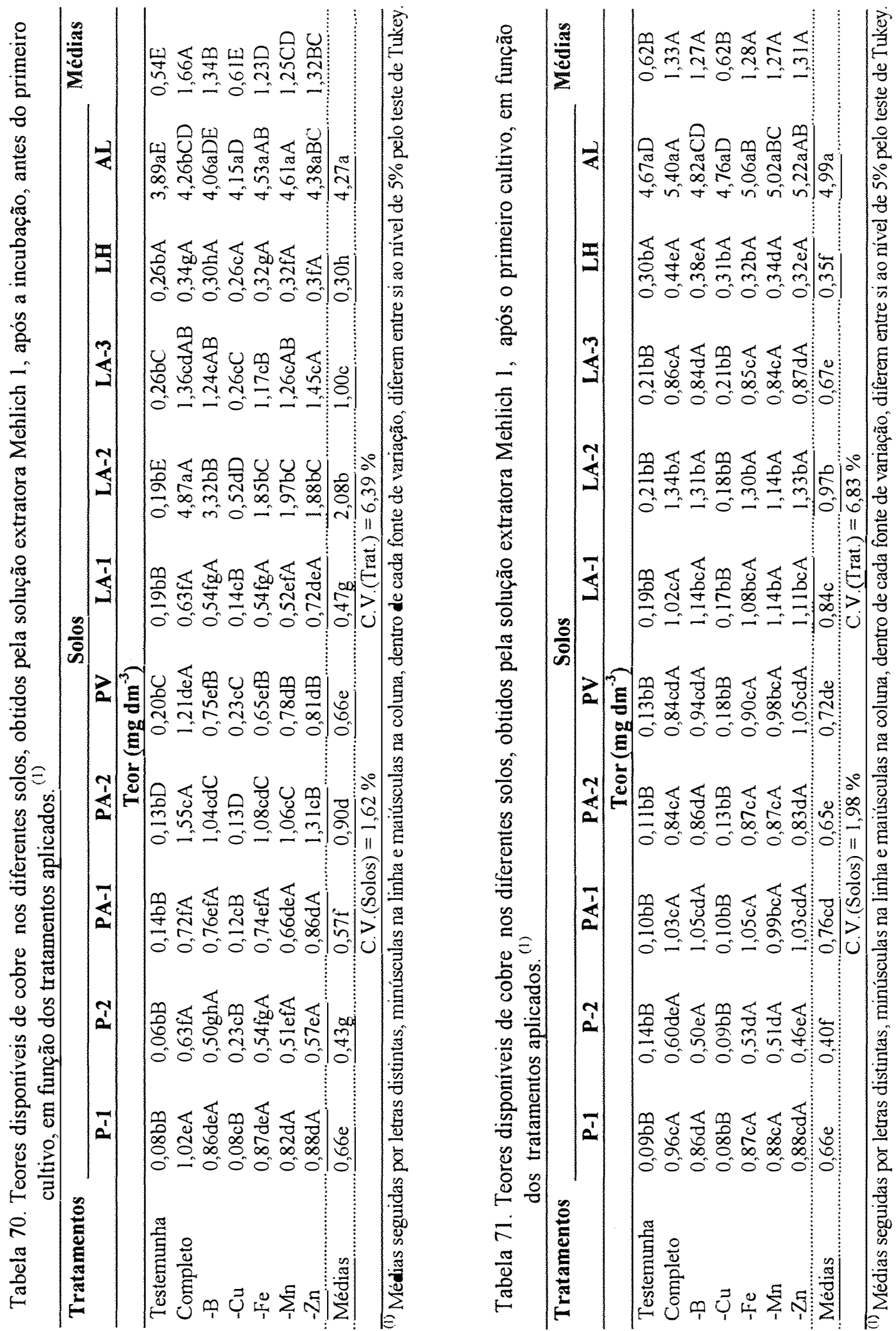

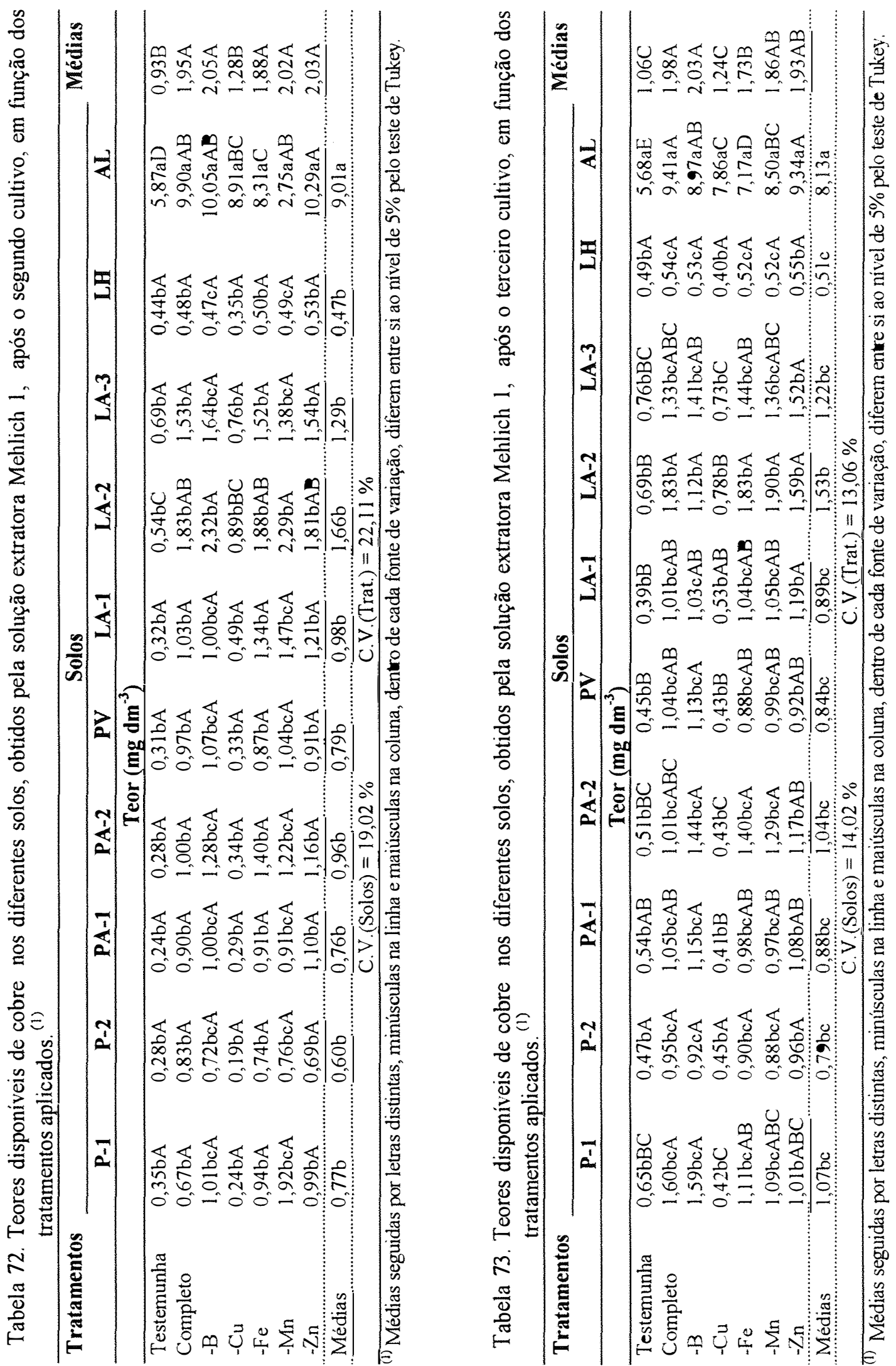

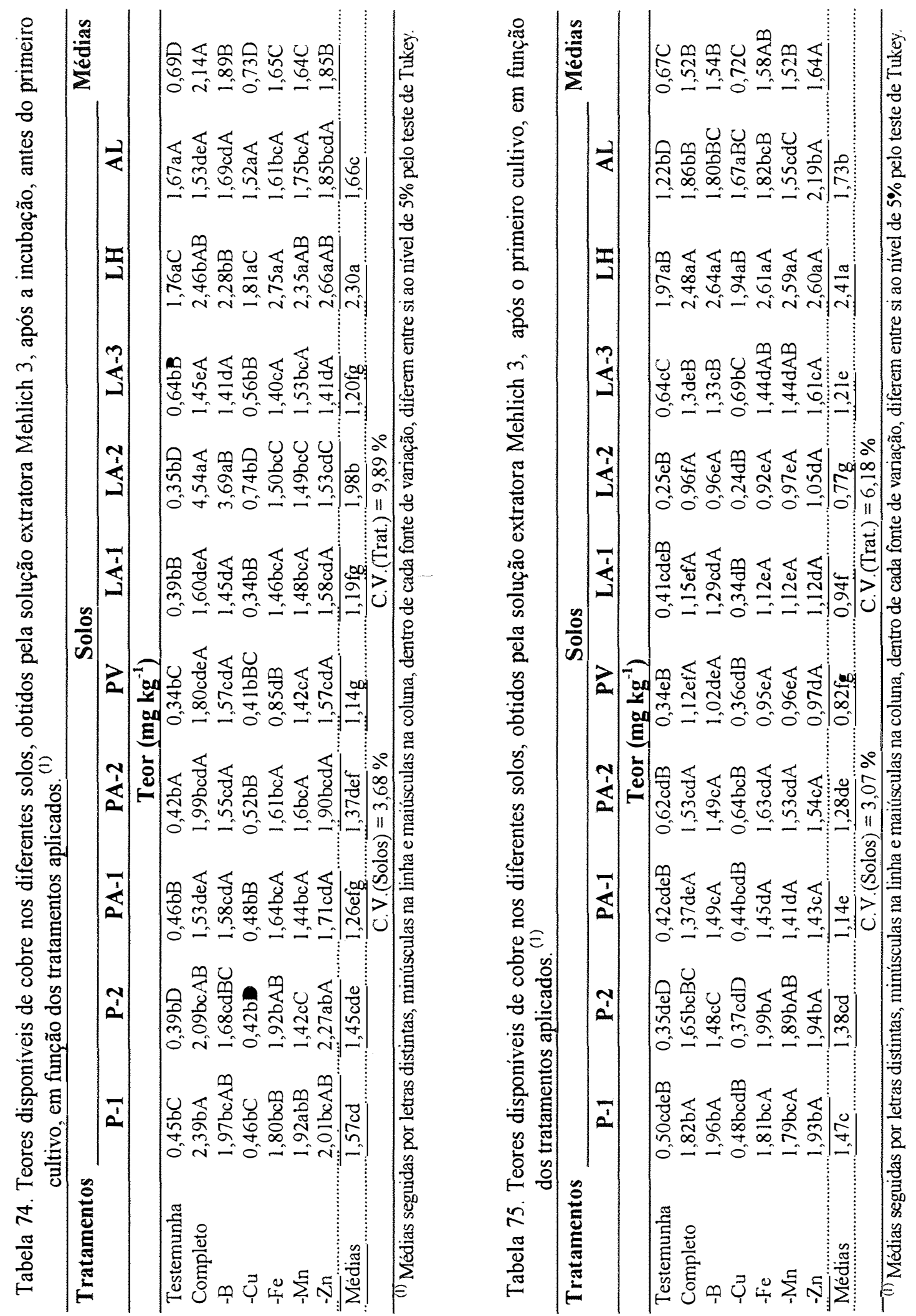

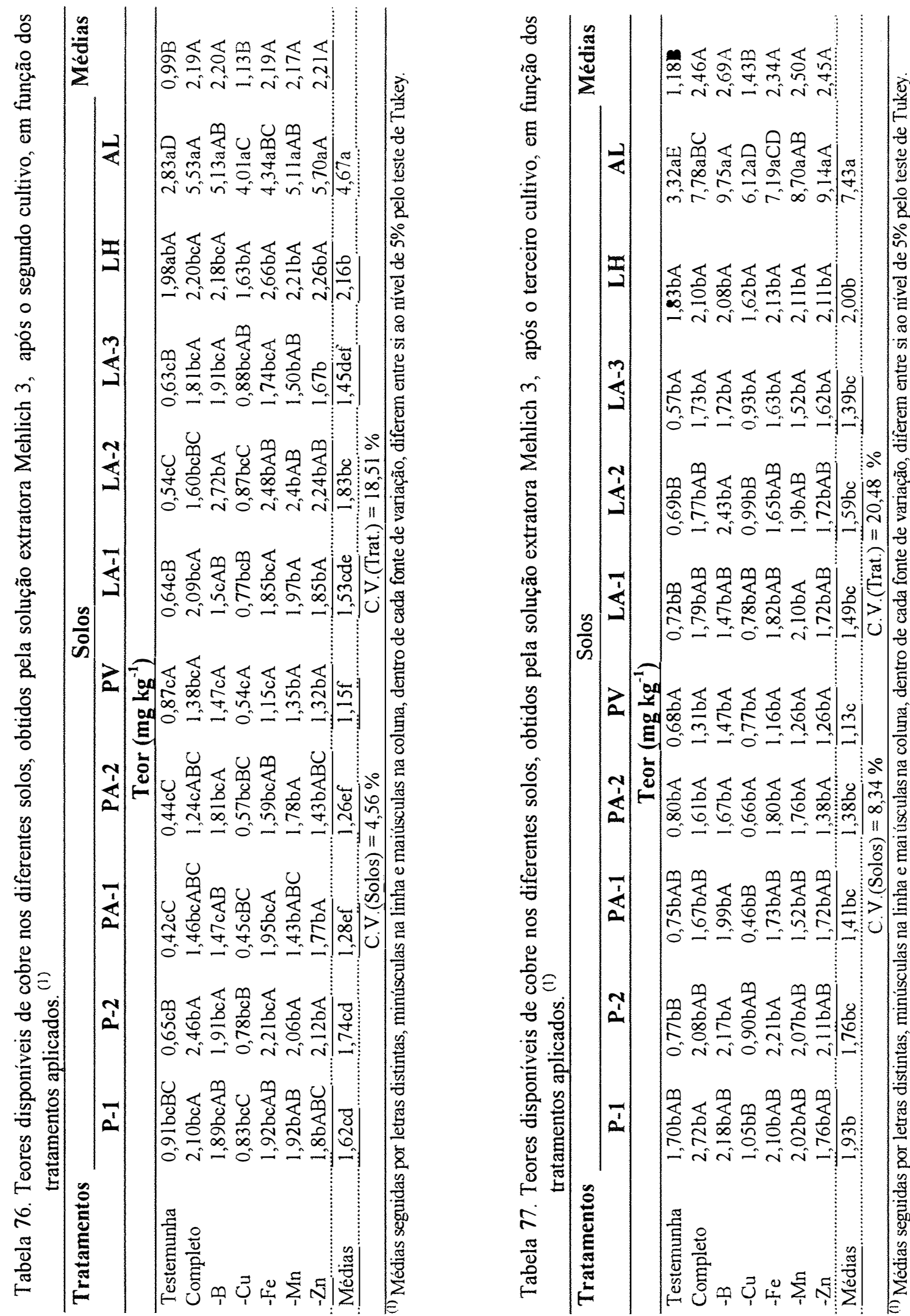

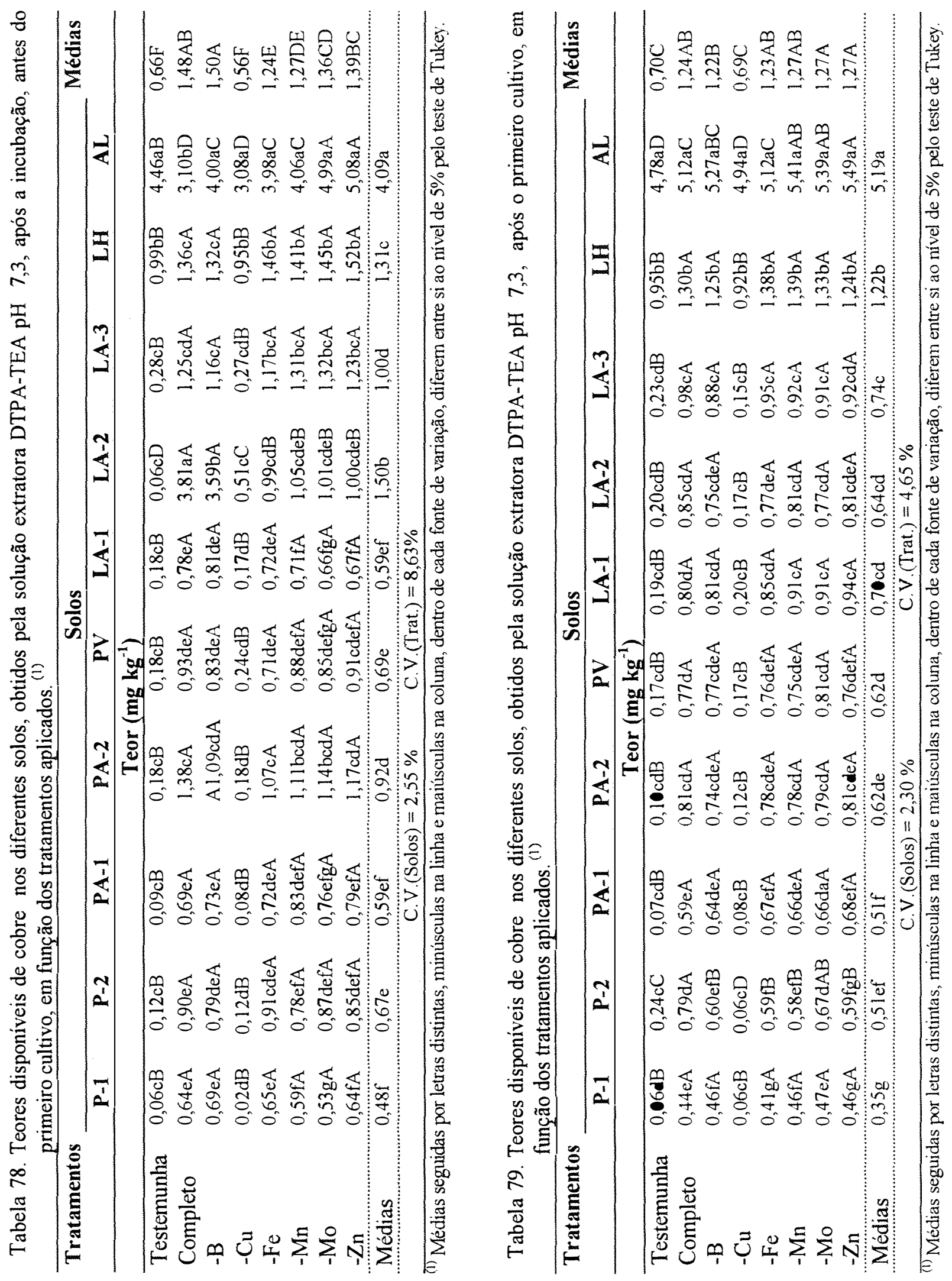

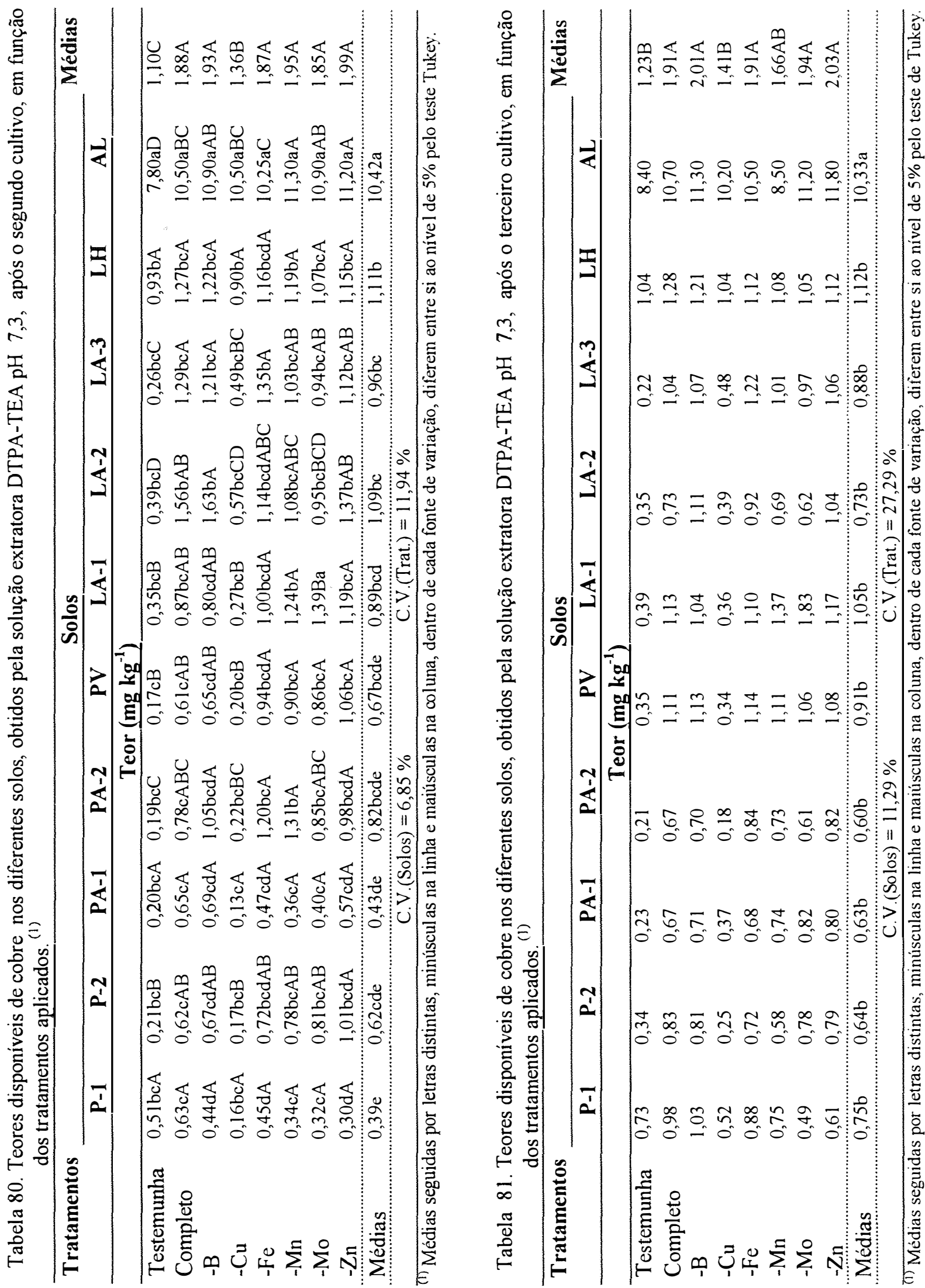

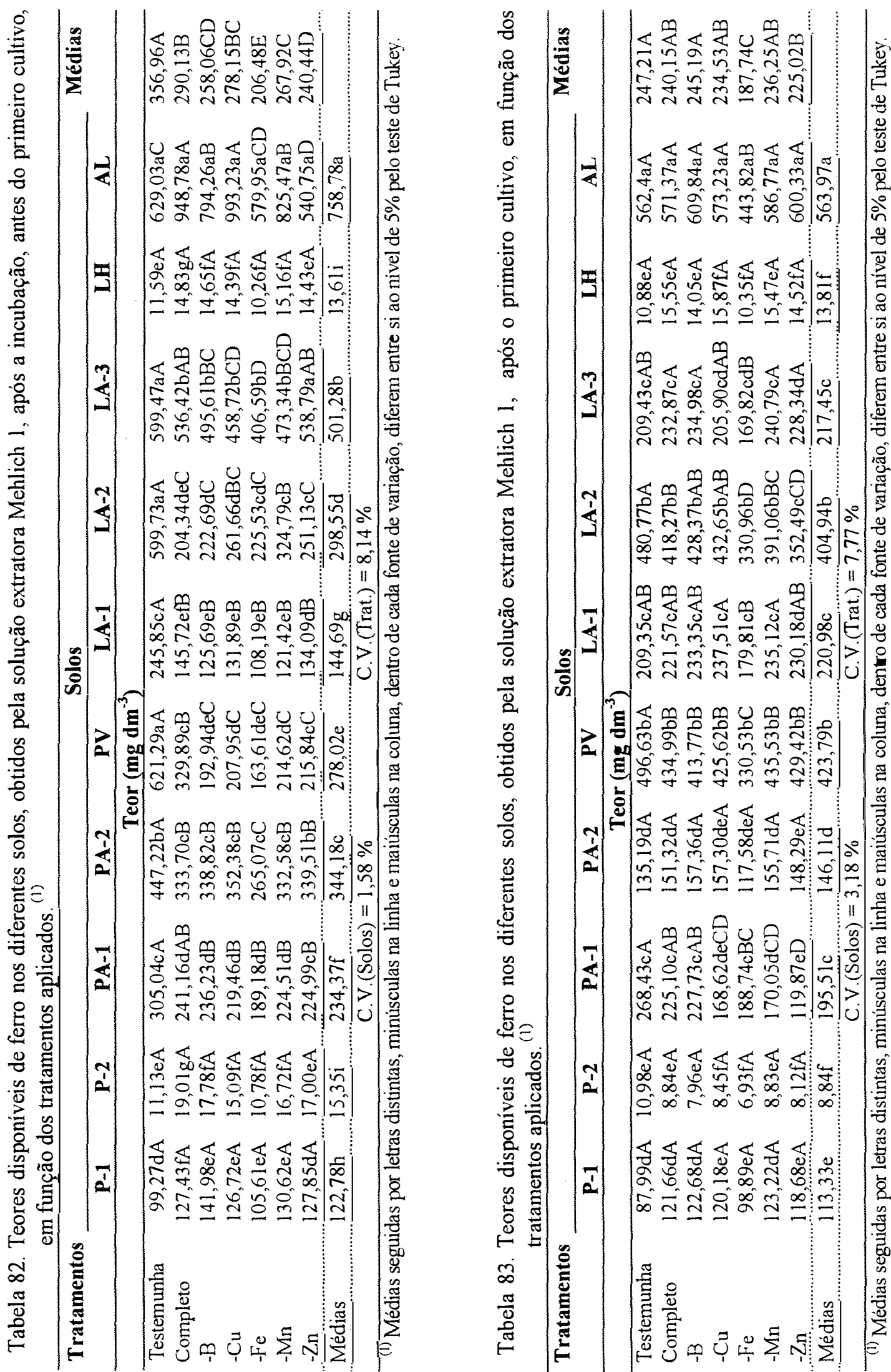
O

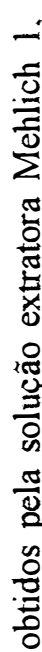

$\frac{\text { o }}{0}$

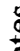

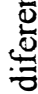

$\stackrel{\text { ֻ }}{=}$

竞

D.

急

$\frac{2}{0}$

氙

政

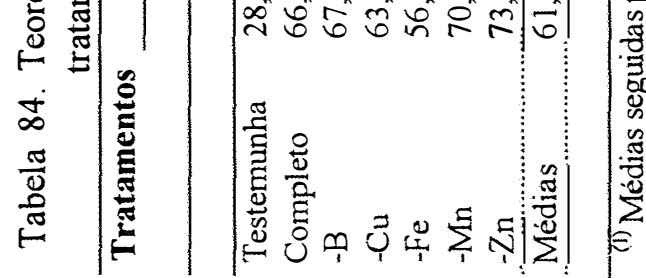

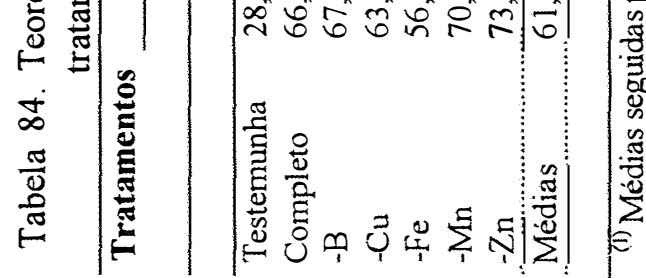

لـ

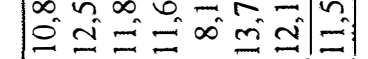

$\varangle m m m m m$

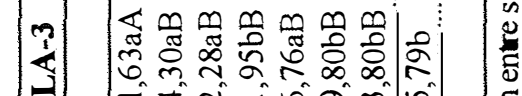

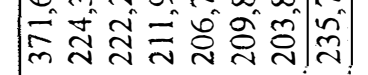

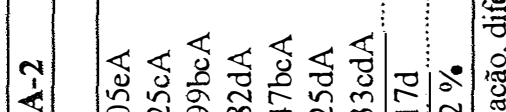

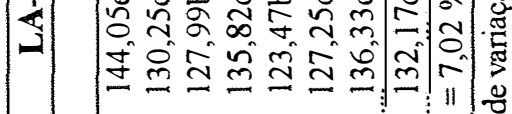

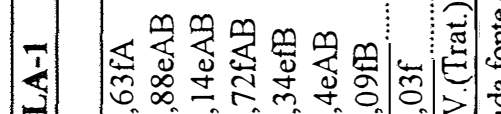

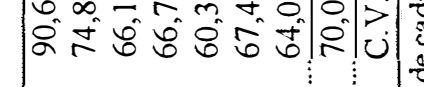

है

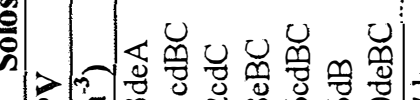

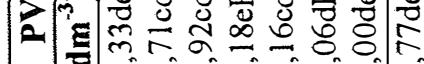

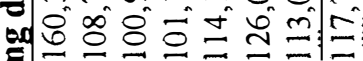

틀

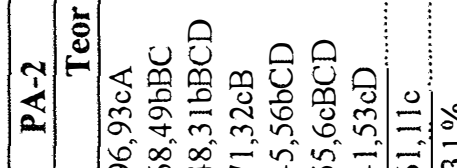

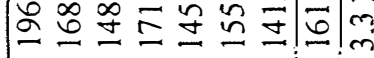

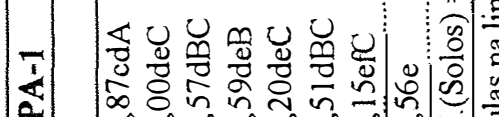

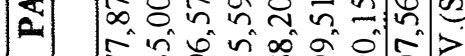
ミ

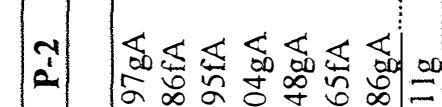

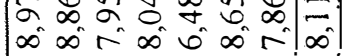

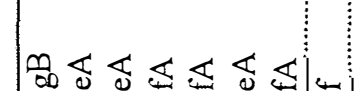

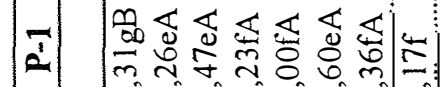

党

롱

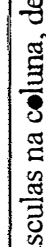

苞

焉

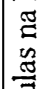

章

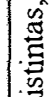

递

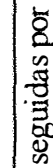

莺

?

荧

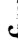

\%

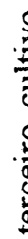



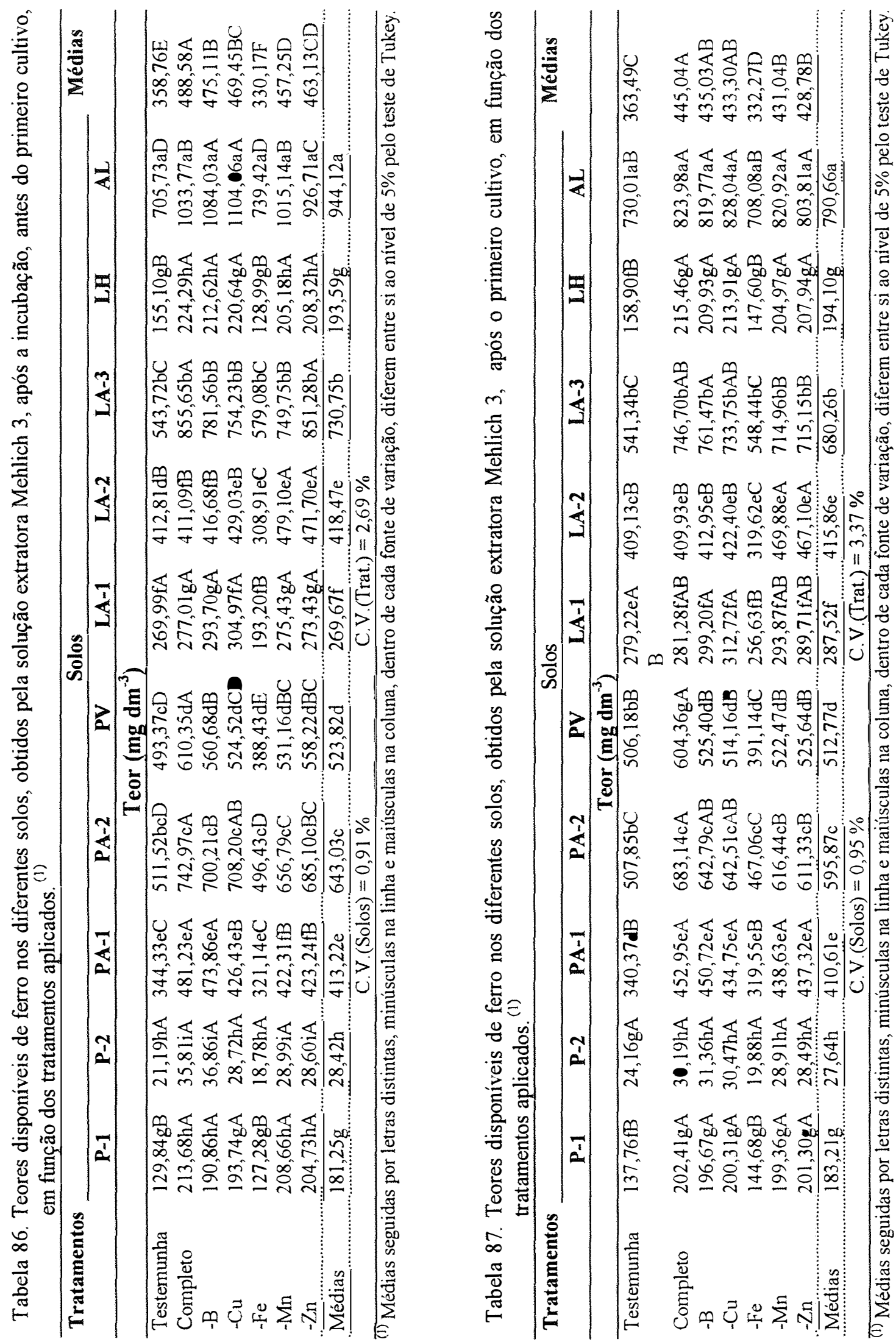
要

争

$\frac{\text { so }}{0}$

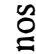

$\stackrel{2}{\stackrel{0}{2}}$

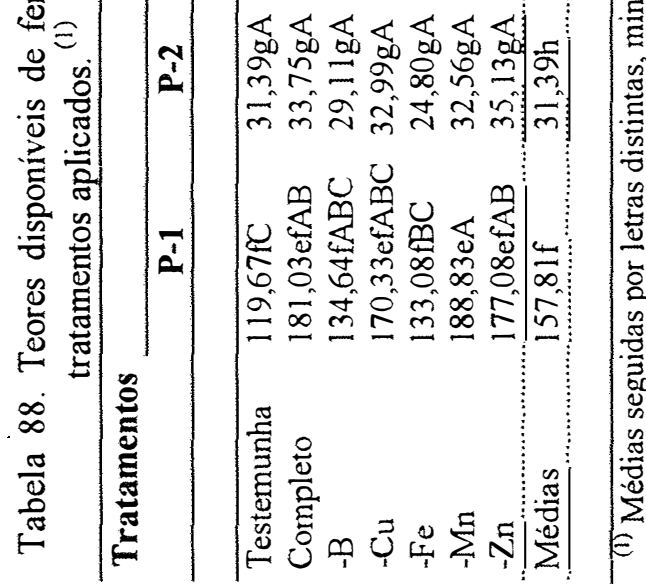

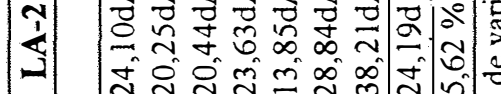

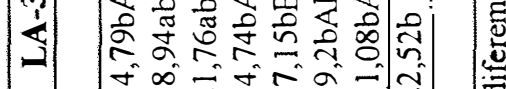

䓠

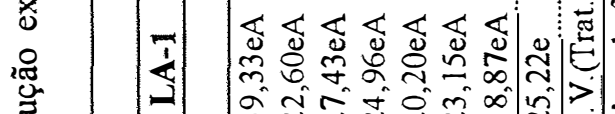

ำำ

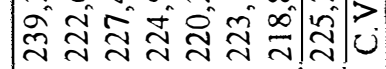

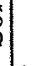

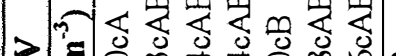

2 :

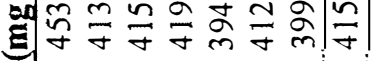

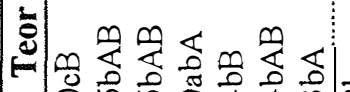

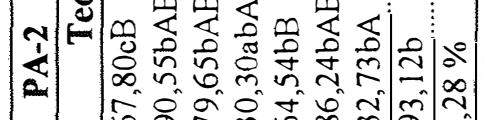

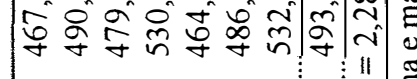

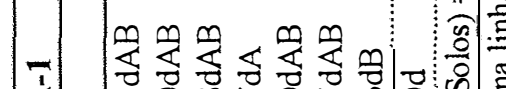

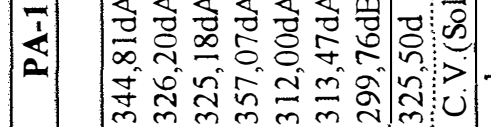

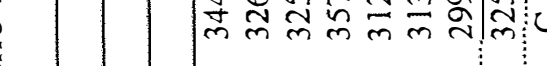

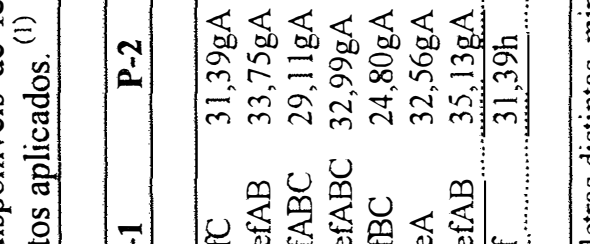

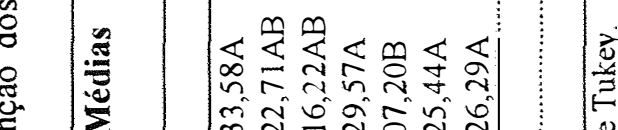

过

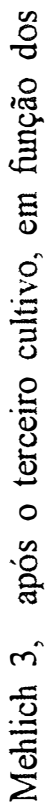

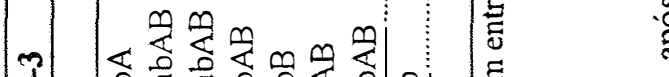

$\sum^{:}$

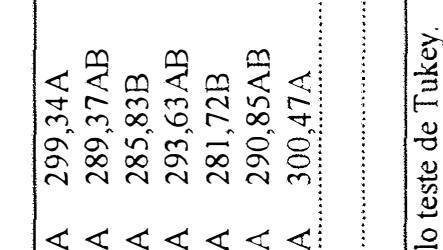

竞

$2 \pi$

龸

$\frac{\pi}{\mathbb{2}}$

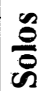

向

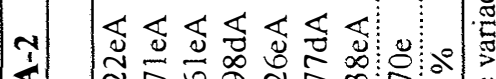

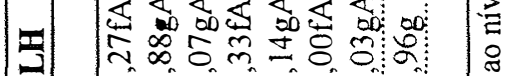

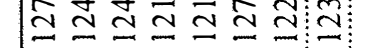

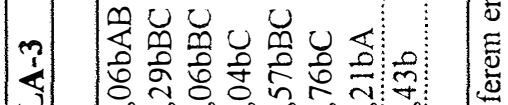

ฐ

然

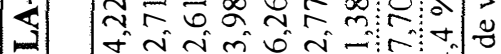

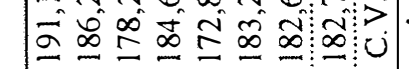

资

$\frac{\text { ñ }}{0}$

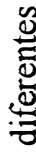

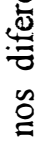

론

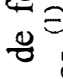

용

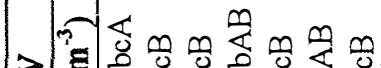

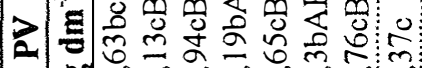

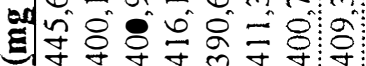

政

힝

立先

a

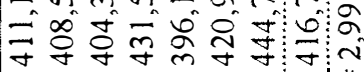

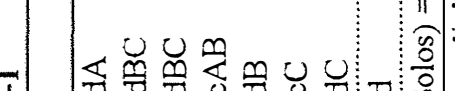

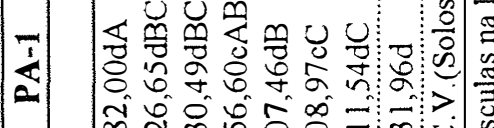

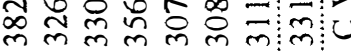

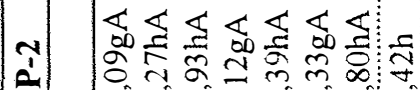

Dिं

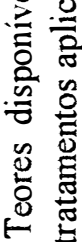

$\infty$

$\frac{\sqrt{0}}{\frac{\pi}{\pi}}$ 


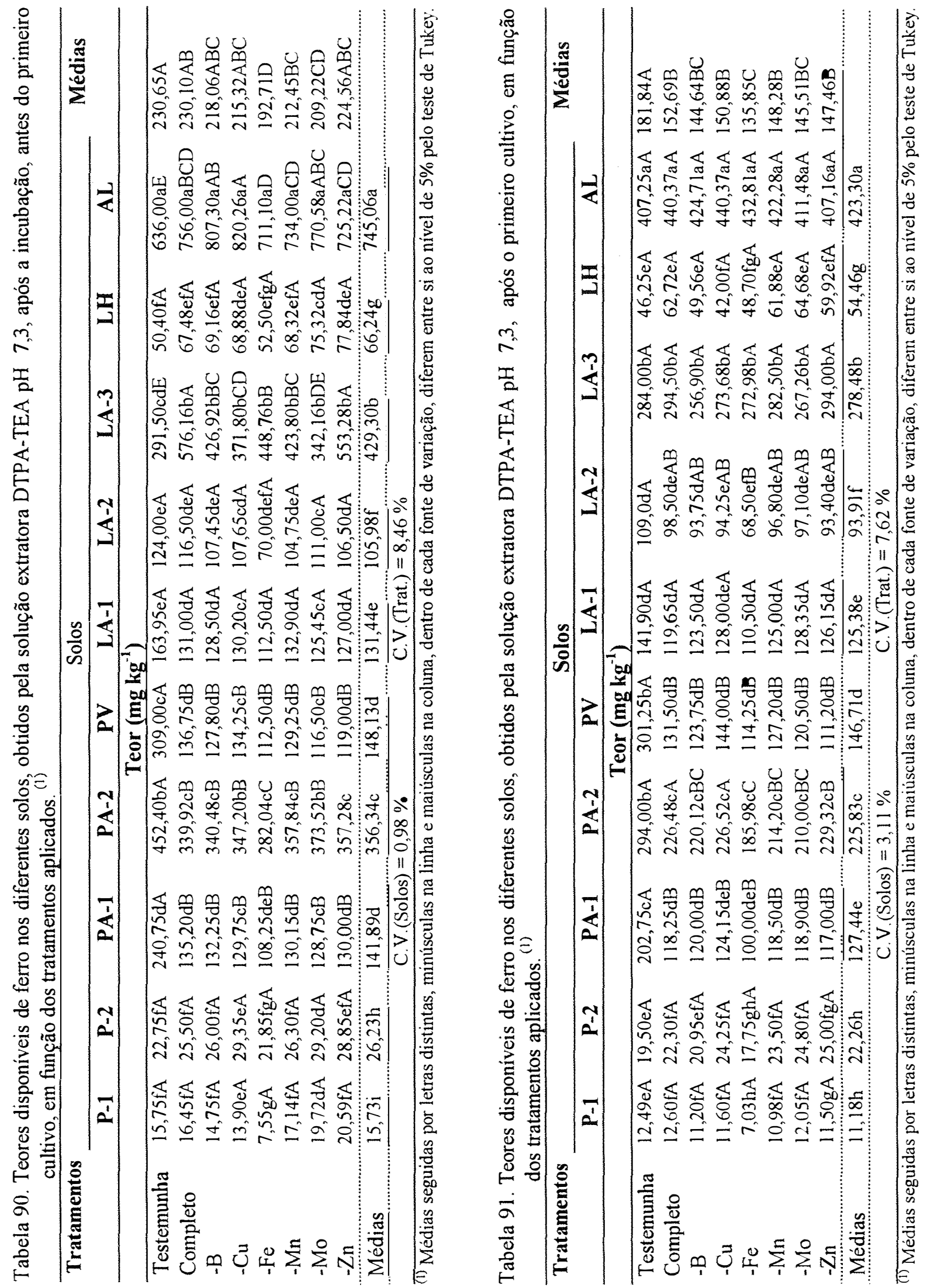




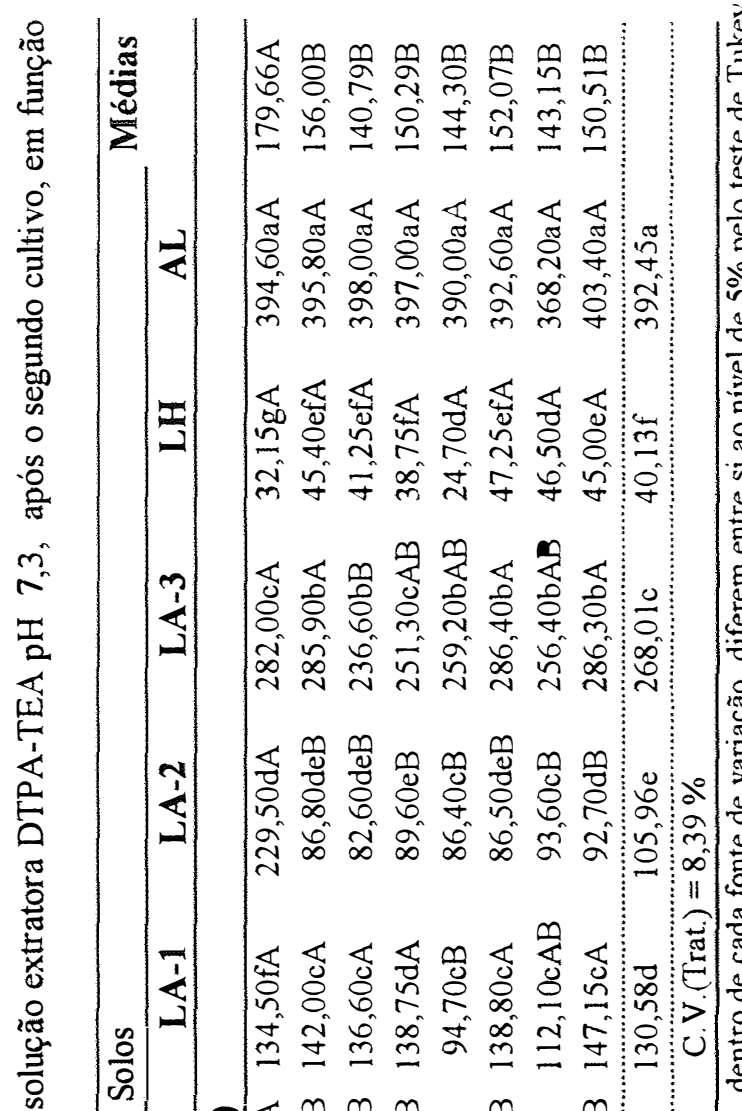

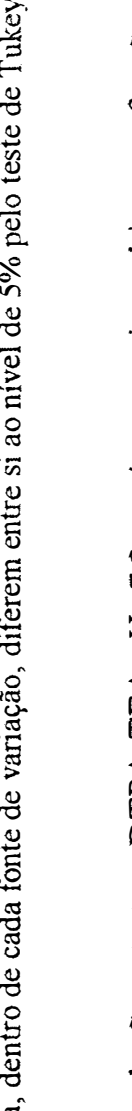

.

กึ

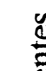

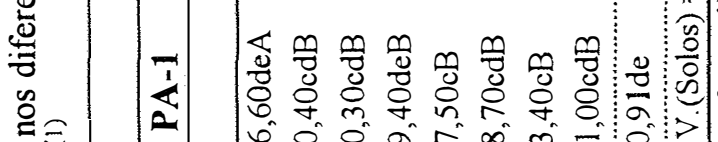

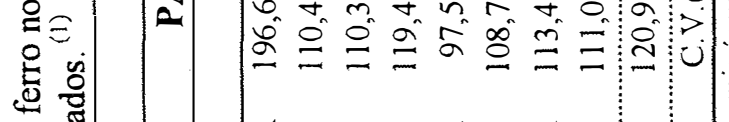

要

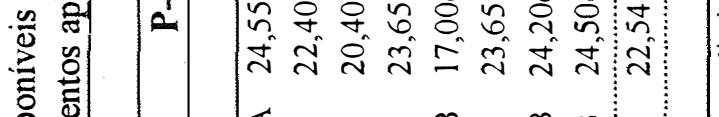

羔

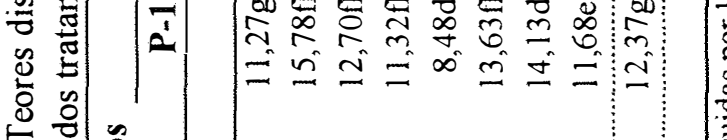

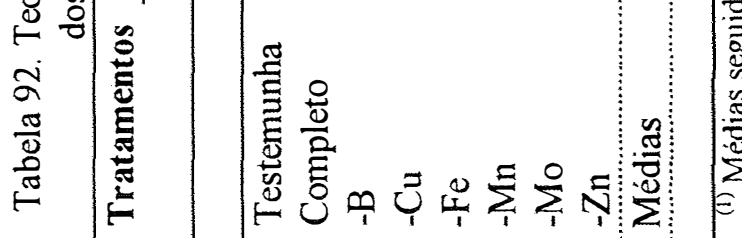

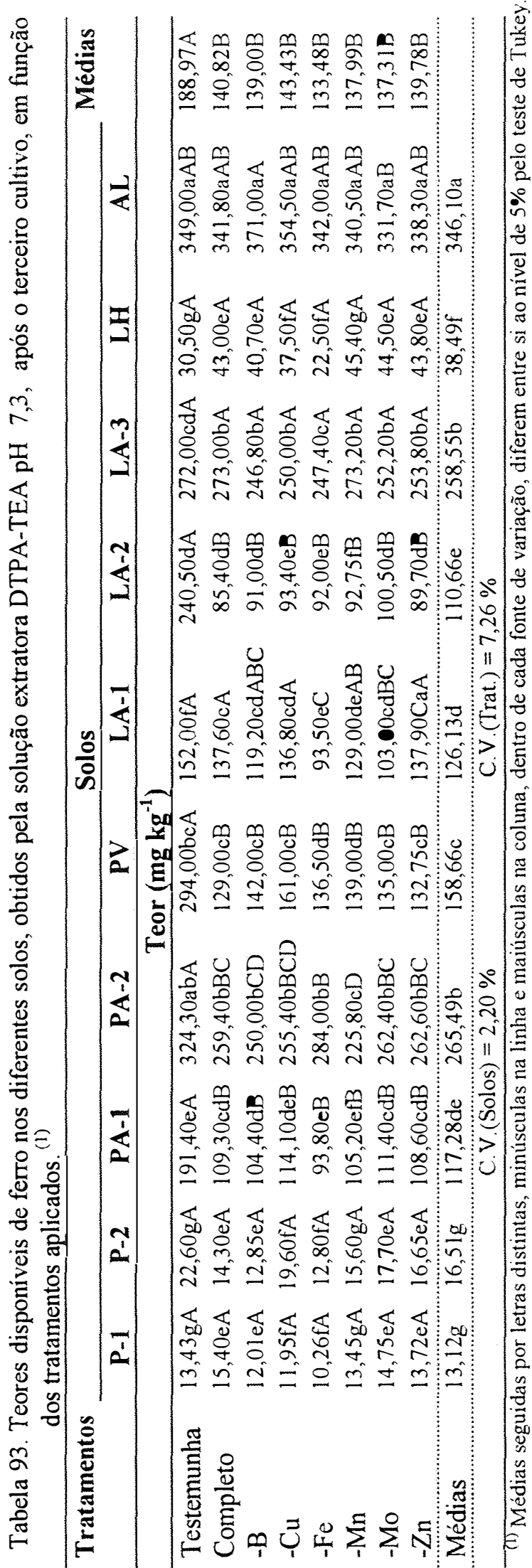



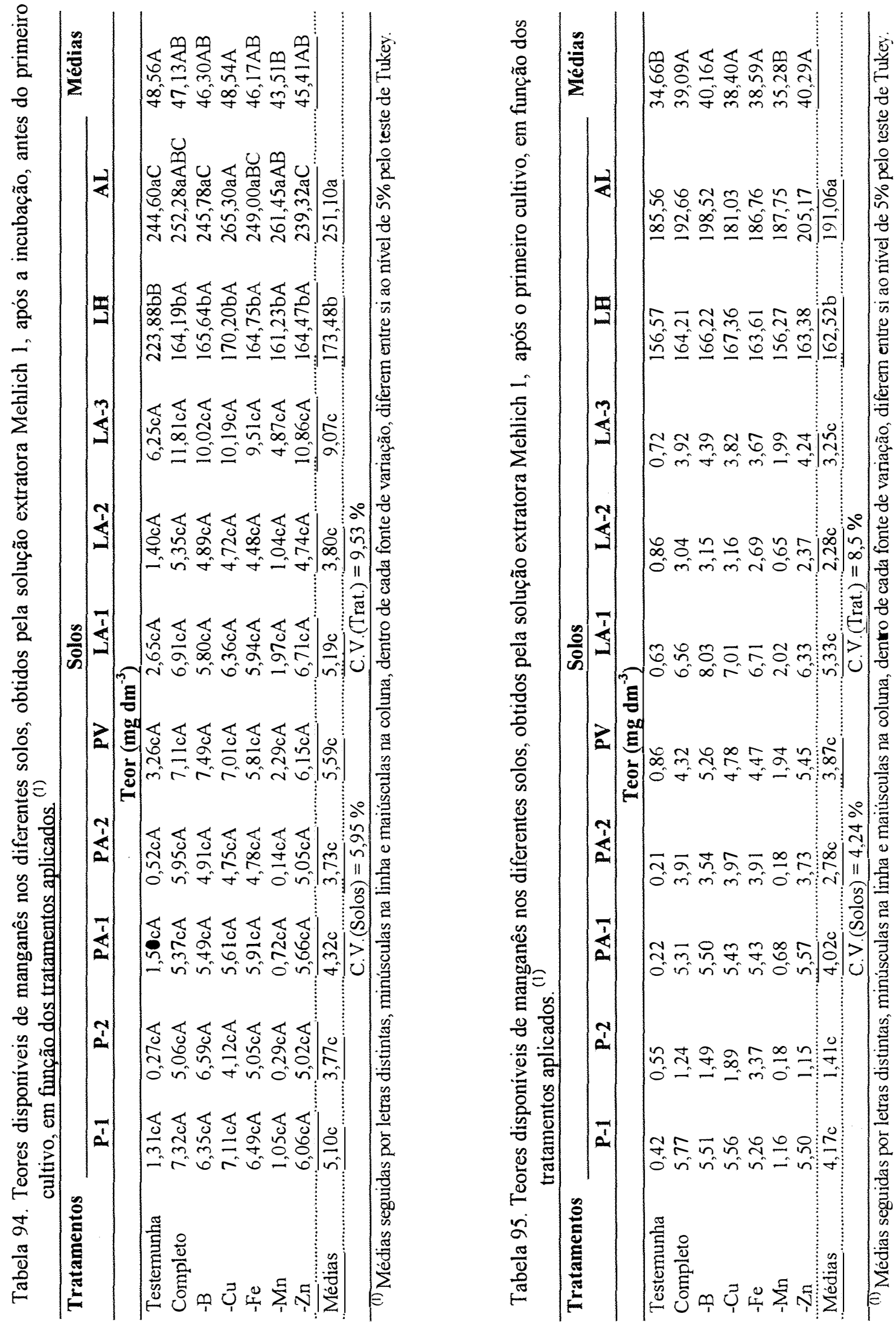

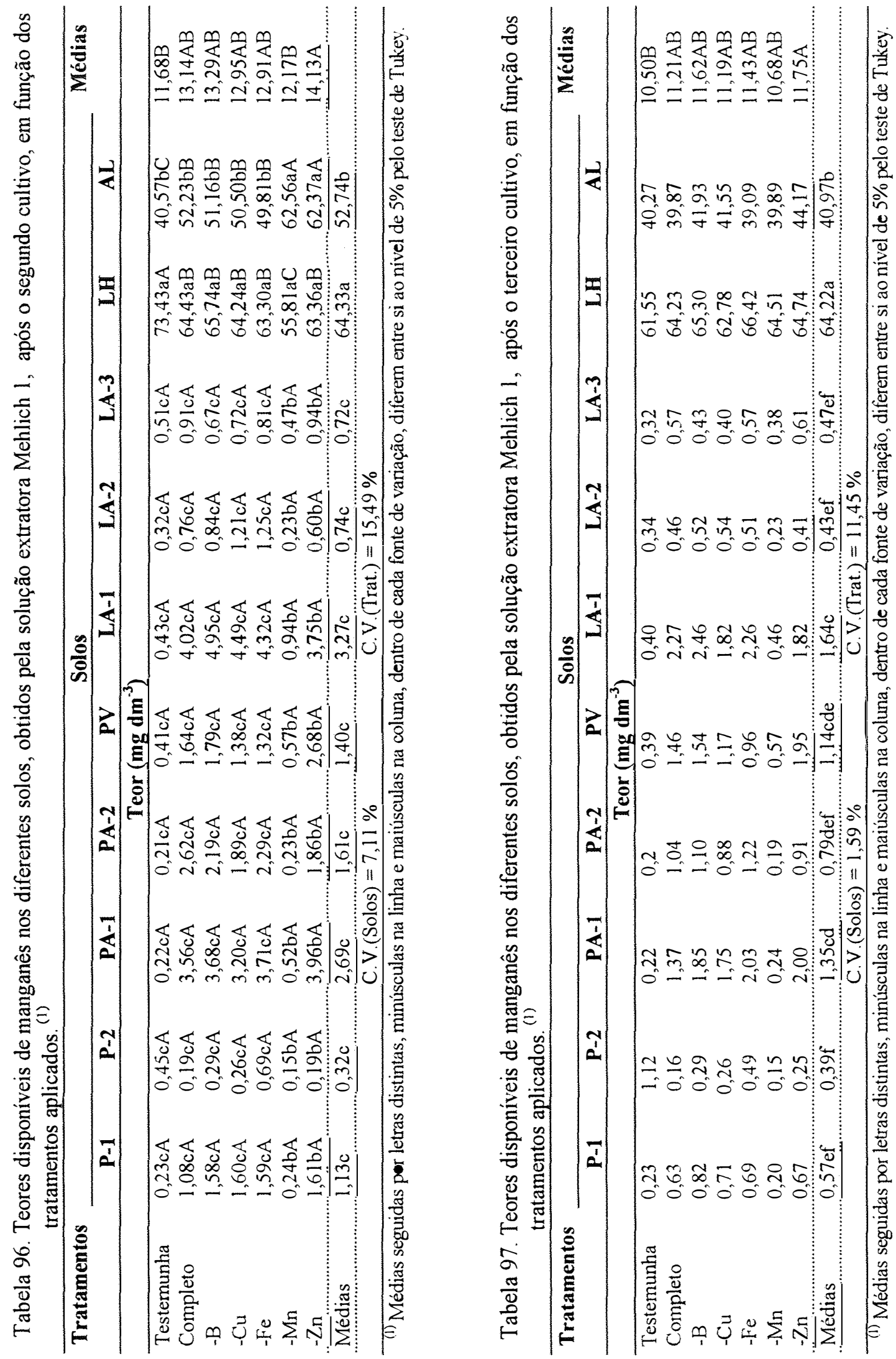

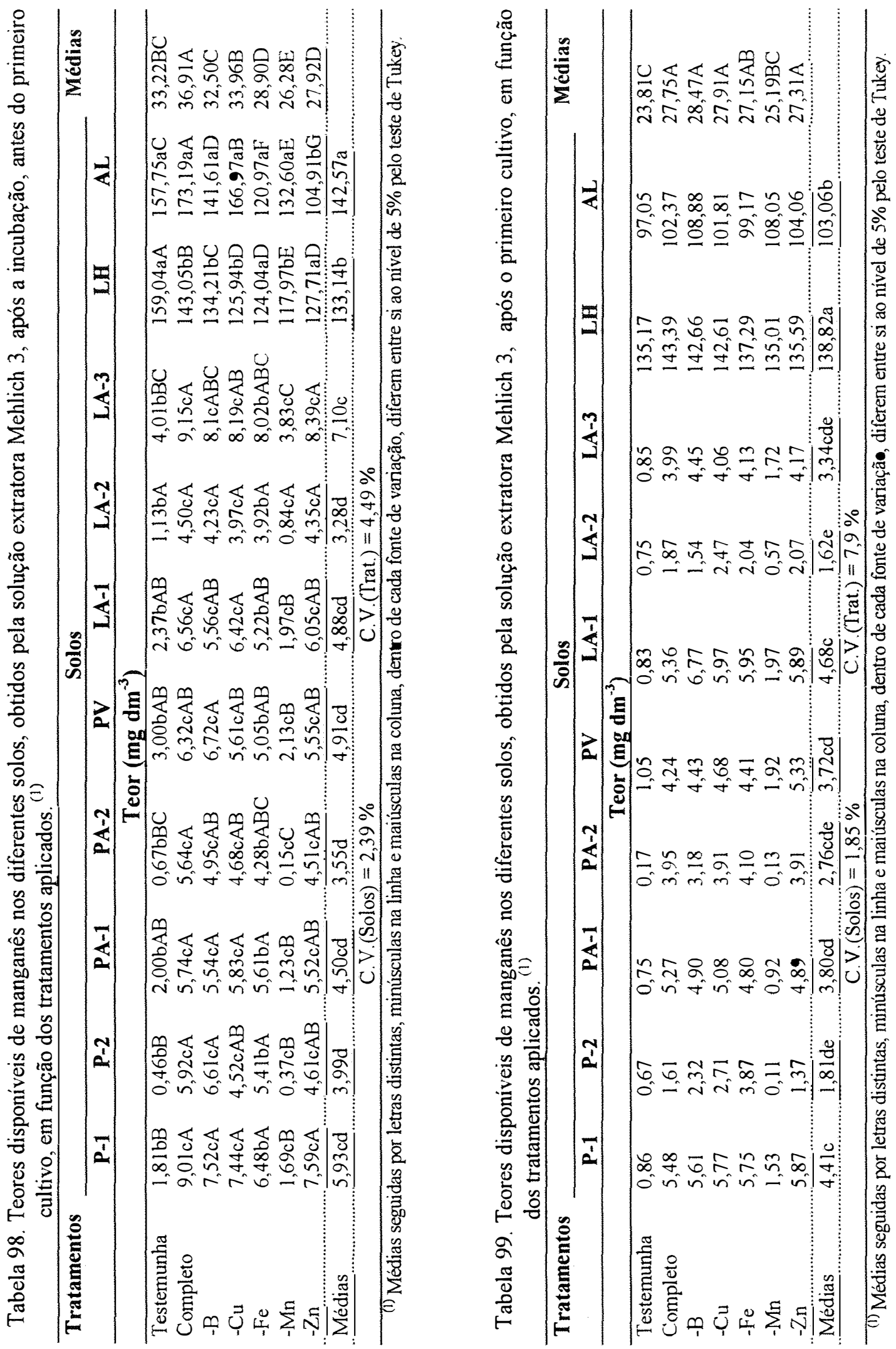

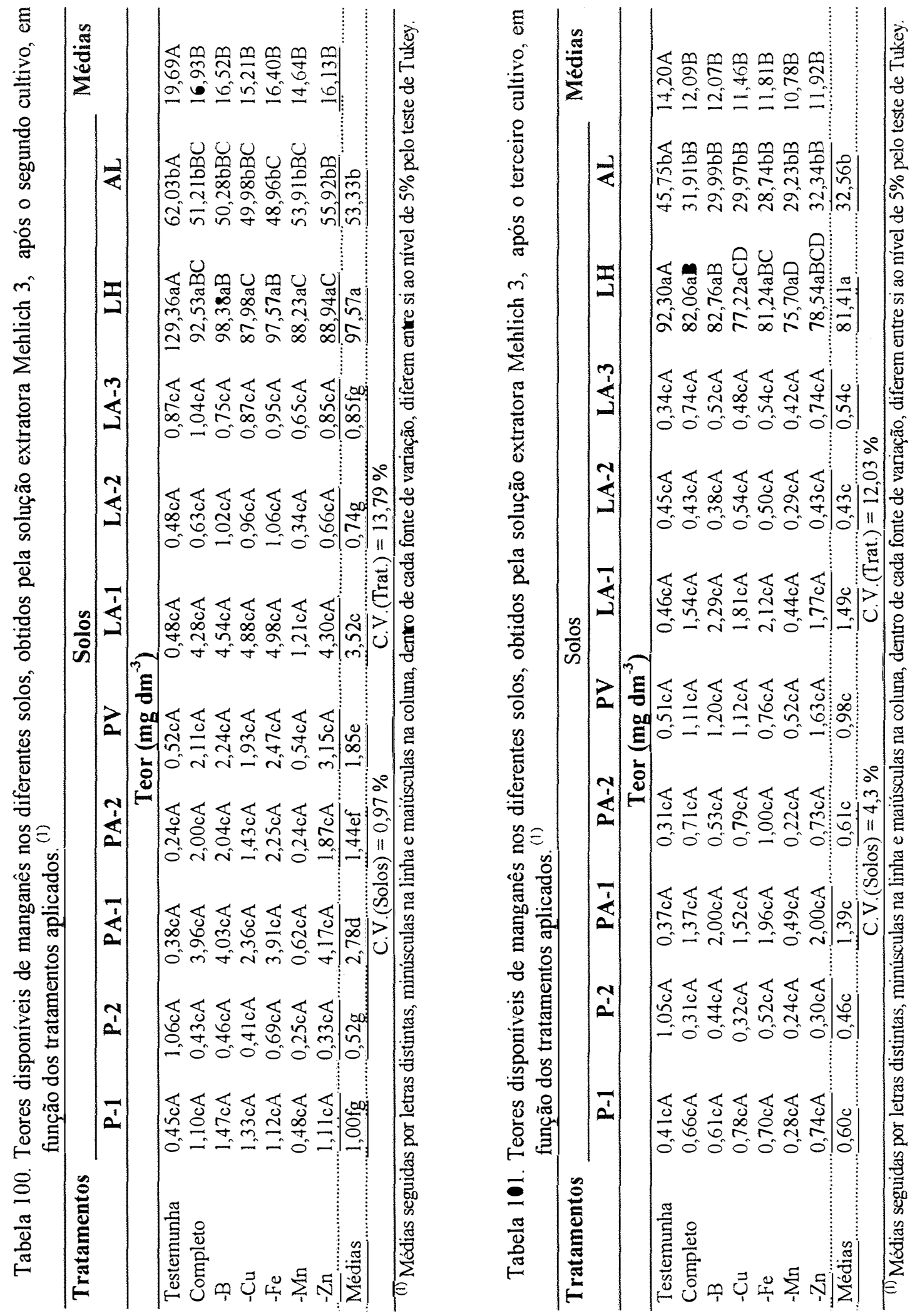


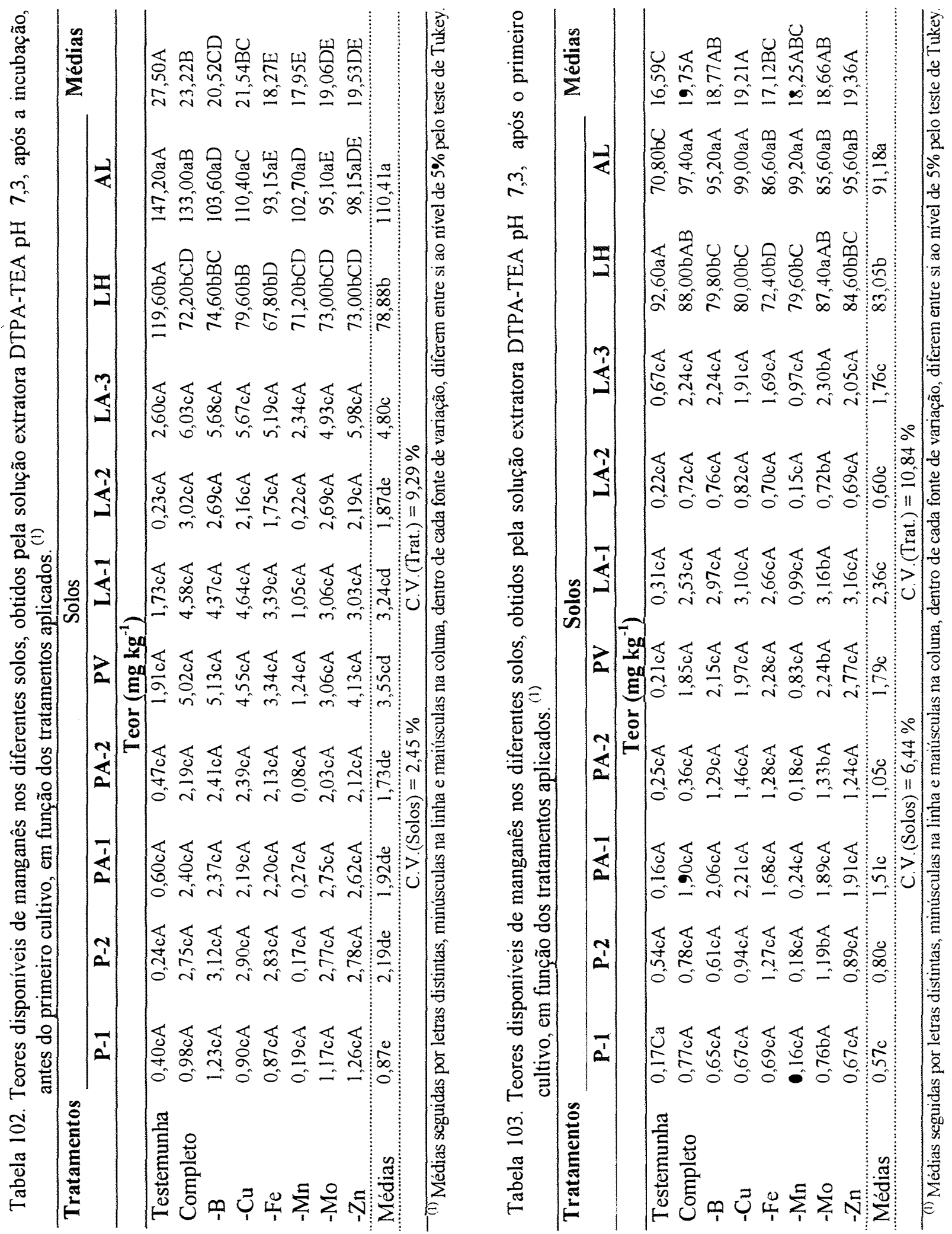



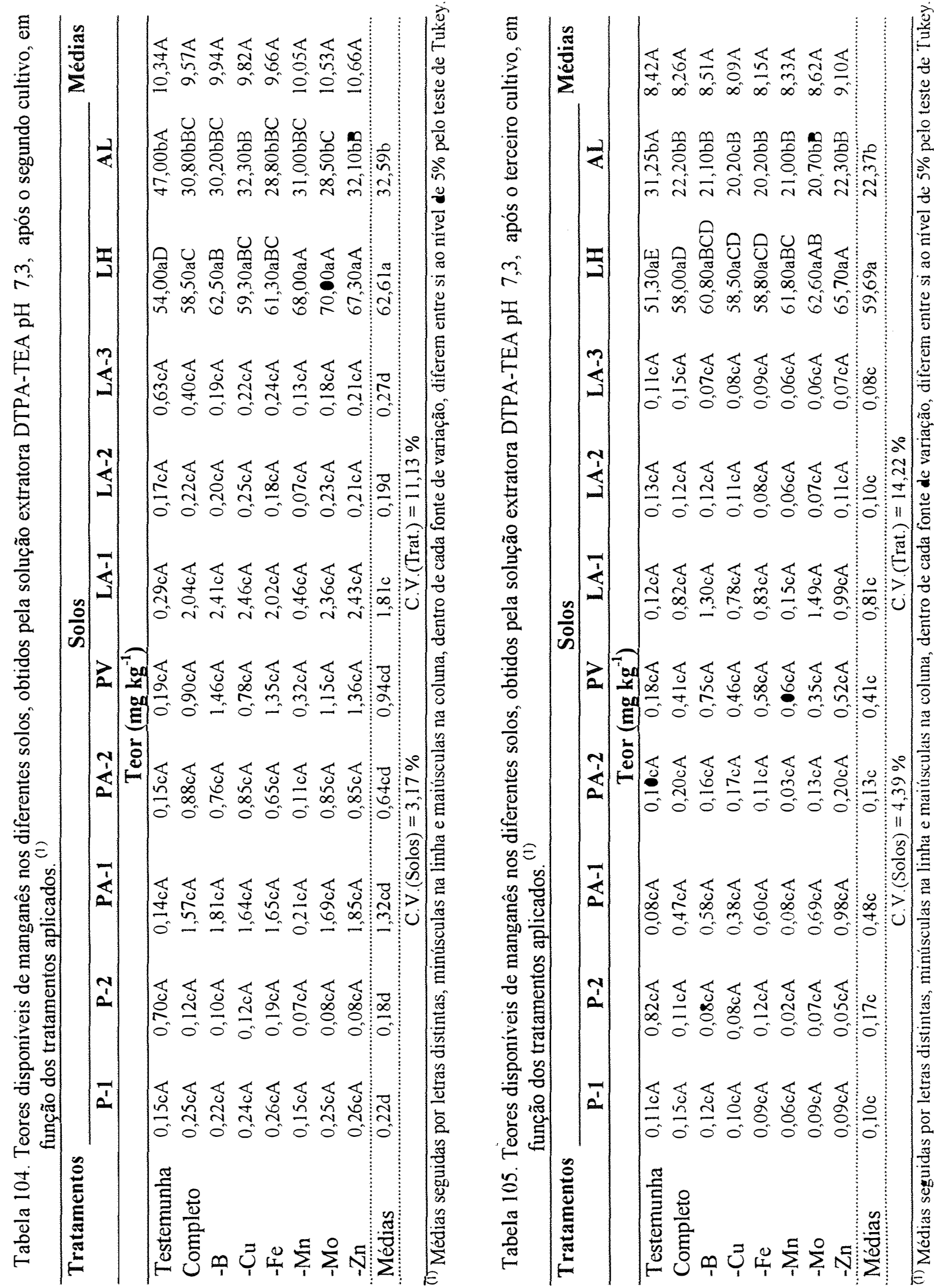

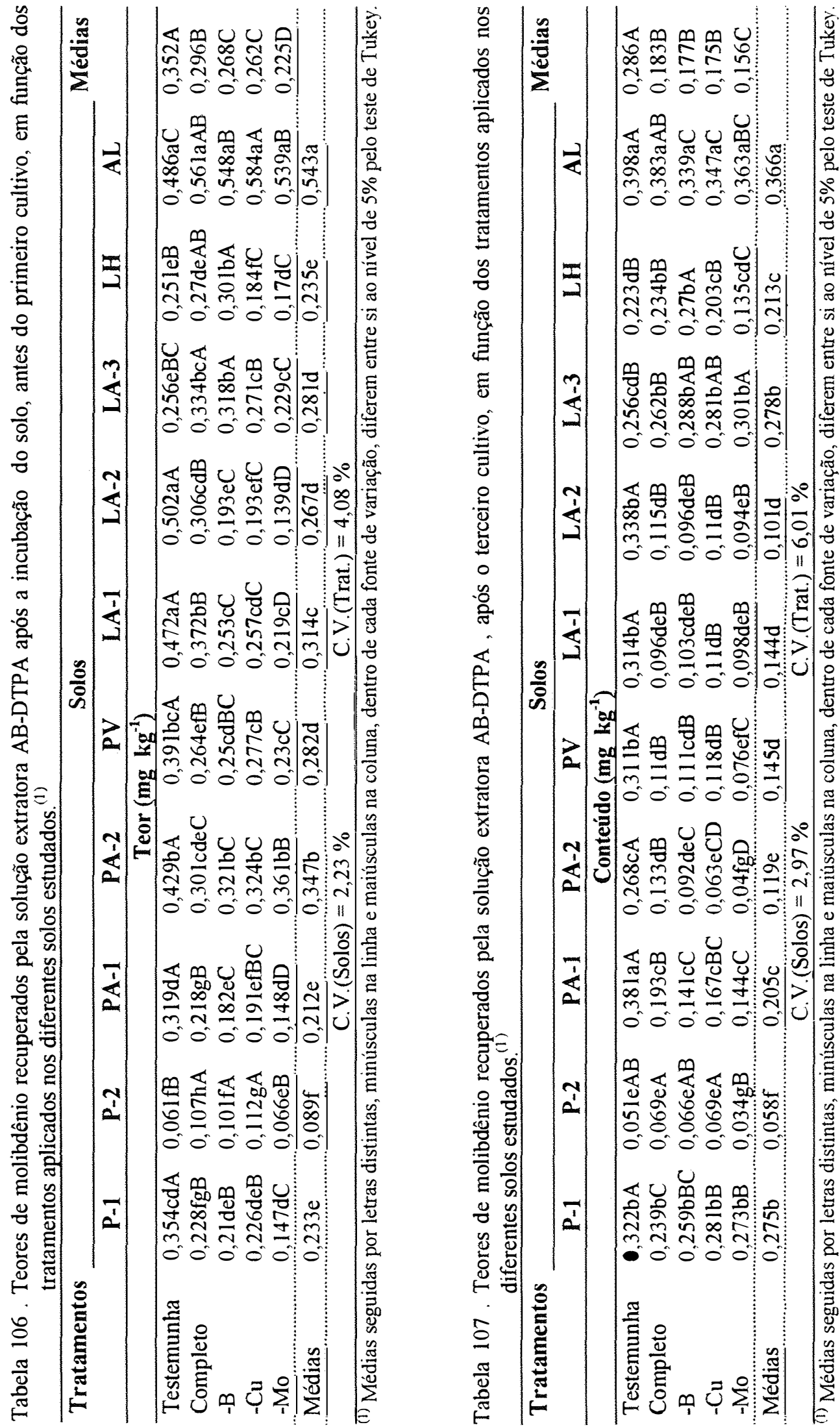

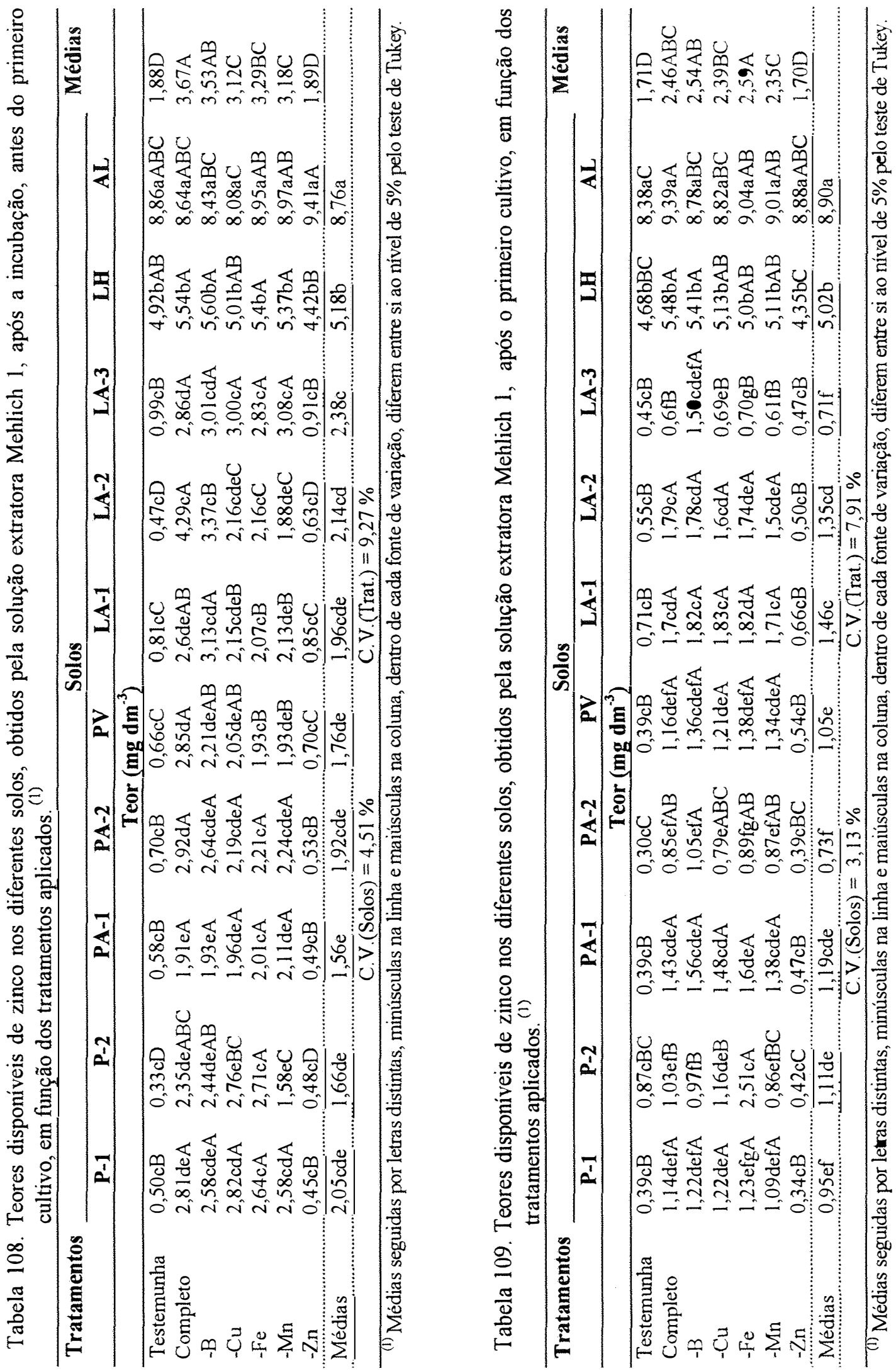

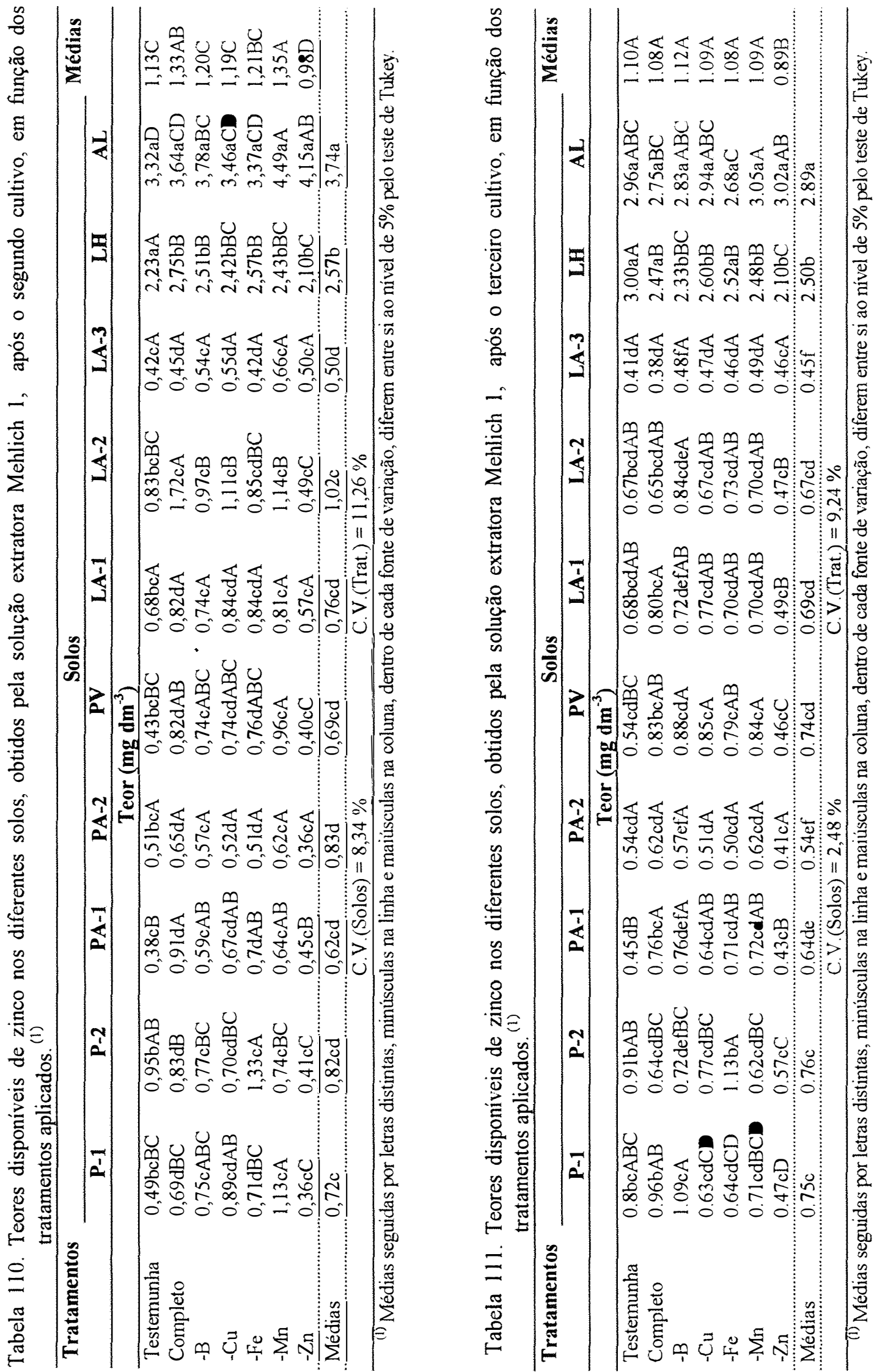

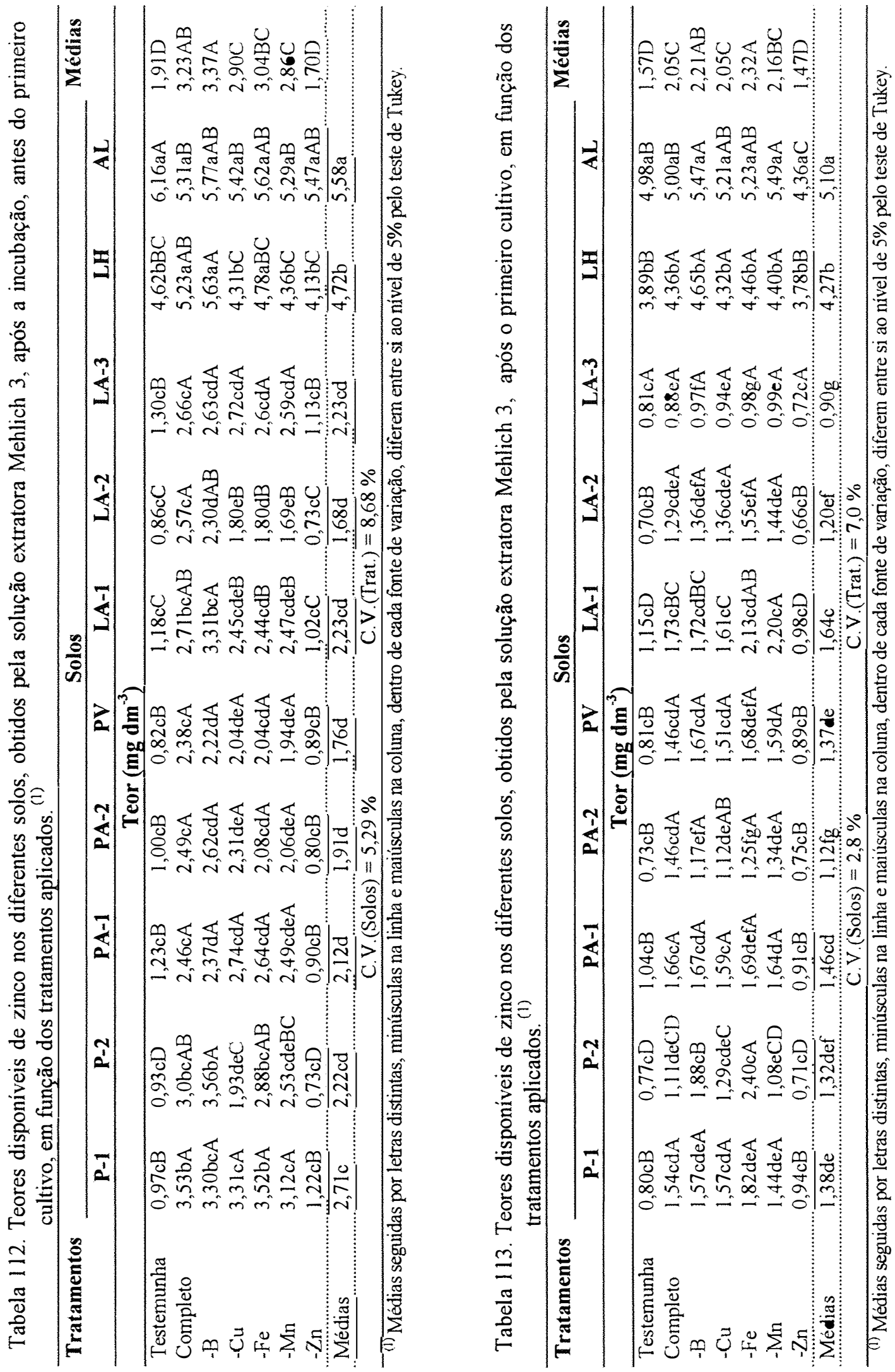

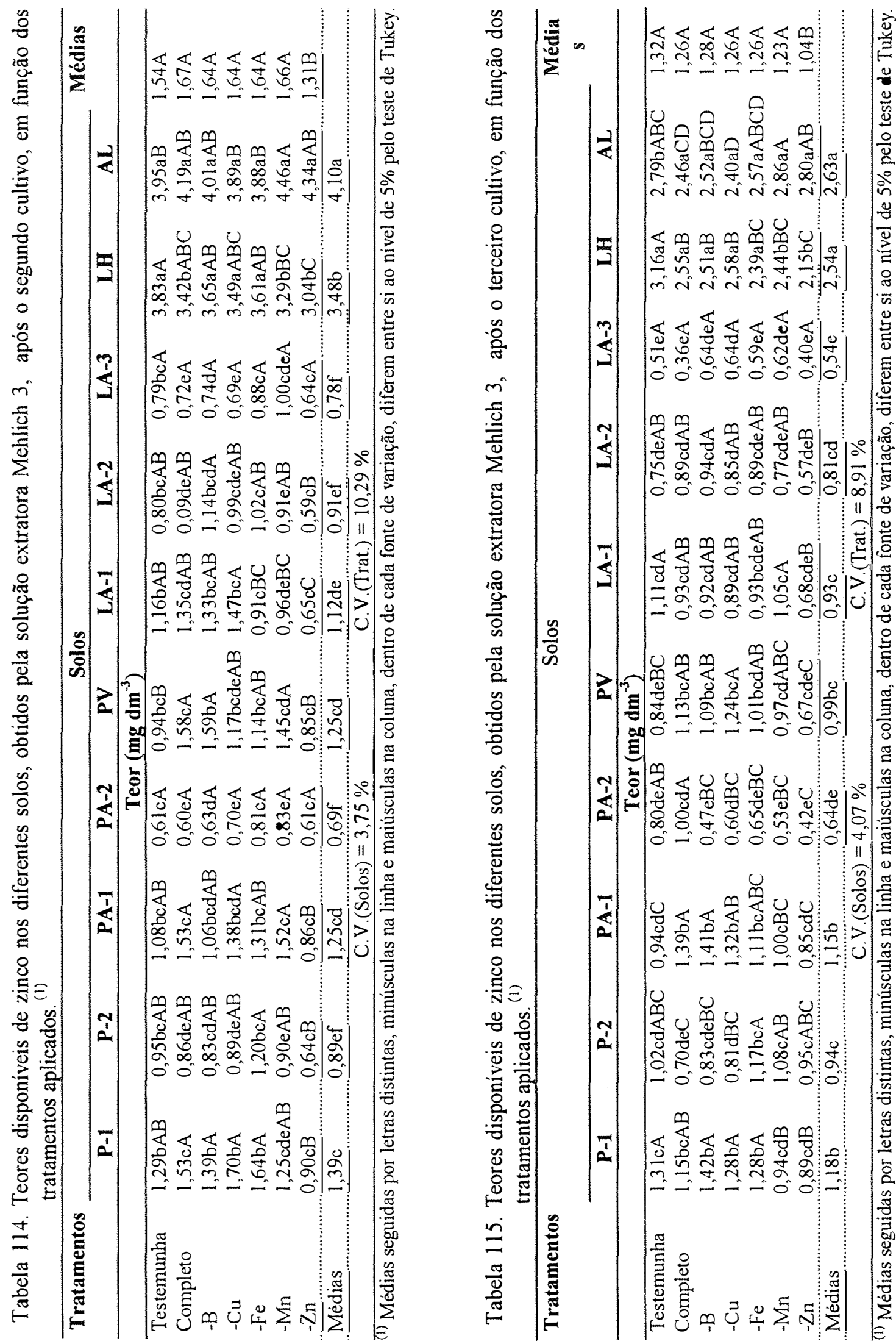





(5)

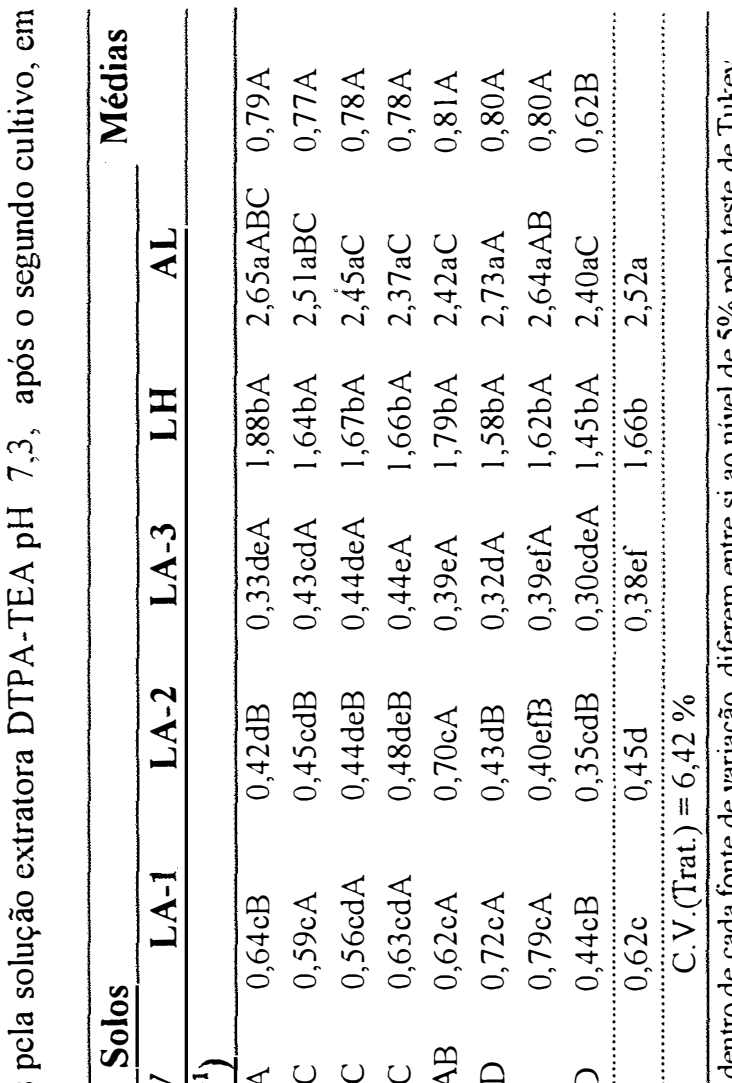

กำ

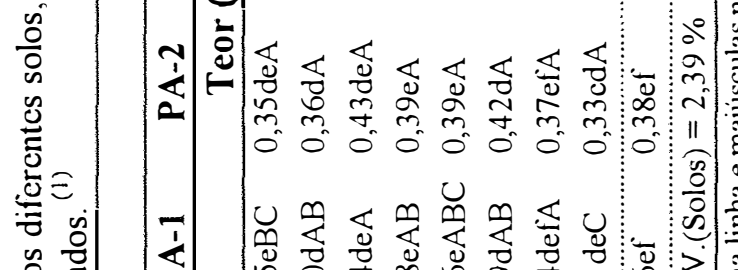

$=$
ֻั?

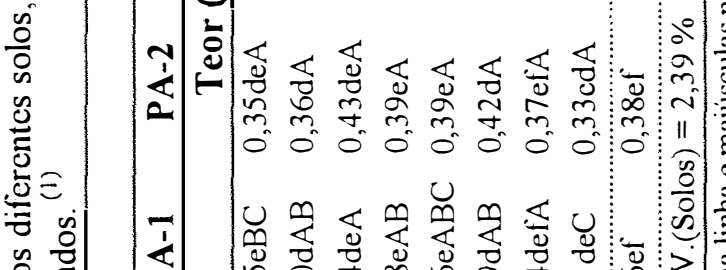

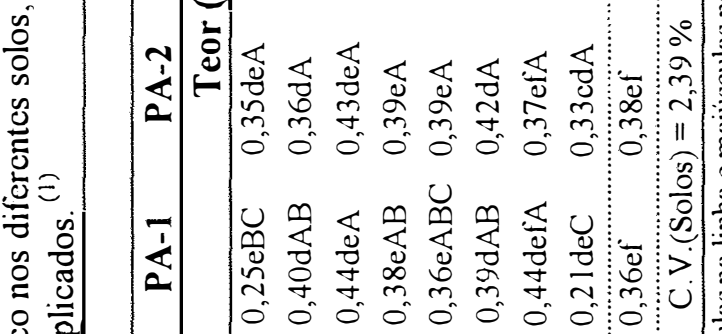

o

竞

ฉ

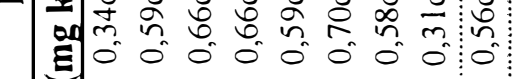

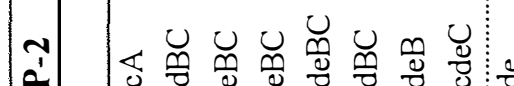

a ड ड

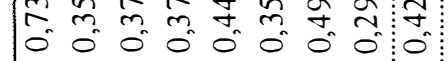

号

บู

额

$\frac{\infty}{0}$

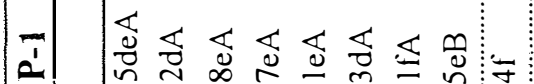

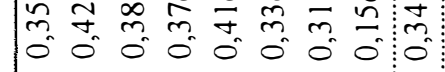

$\stackrel{8}{\circ}$

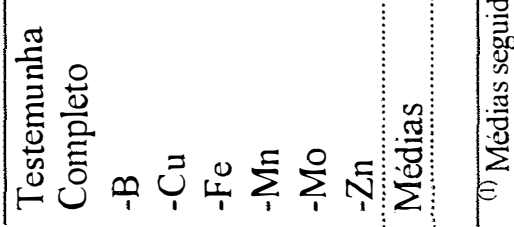

$\Xi$

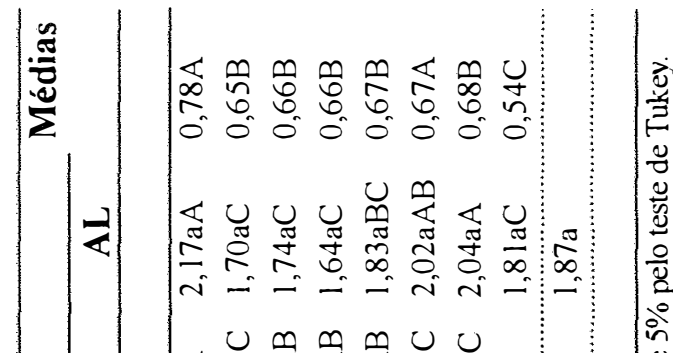

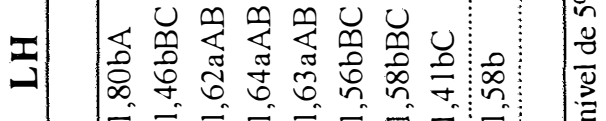

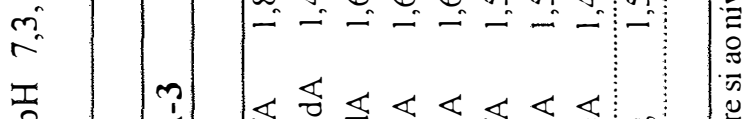

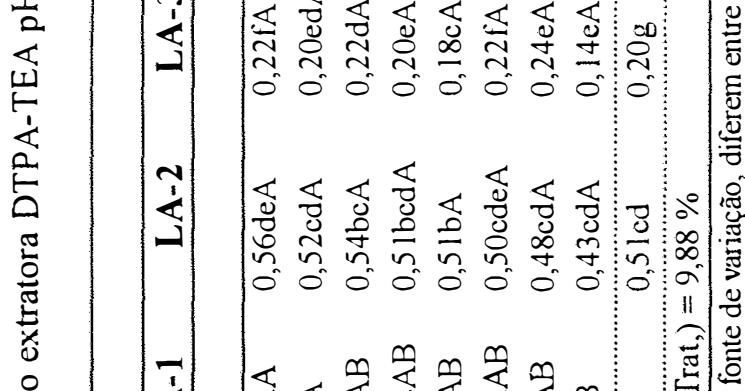

敢

क

$\frac{\pi}{\check{2}}$ 迥

:

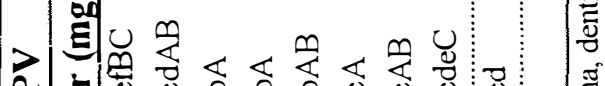

¿

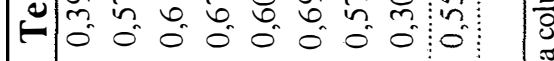

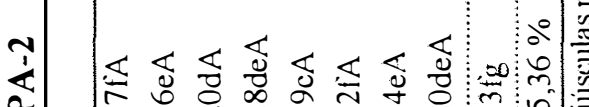

- స 규

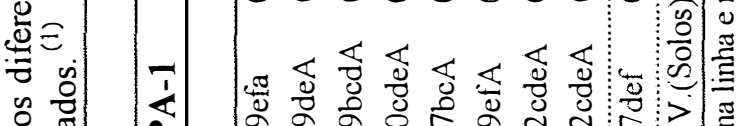

$\stackrel{0}{0}$

要

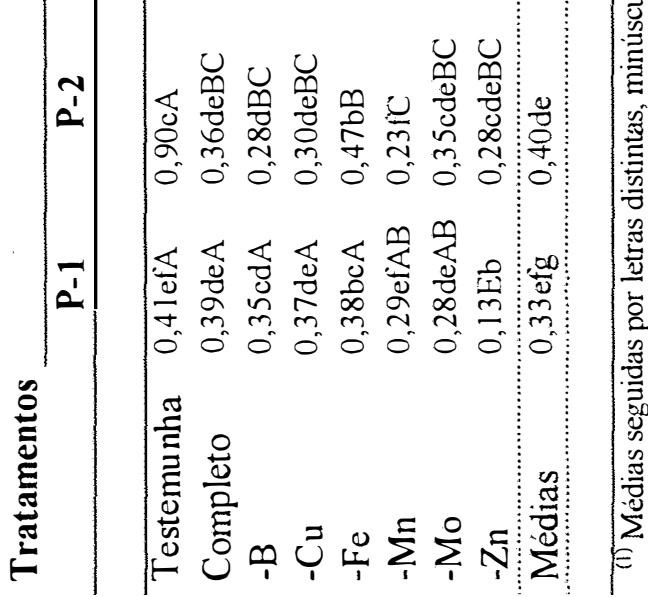


Tabela 120. Teores de micronutrientes em solos determinados com diversas soluções extratoras $\left(\mathrm{mg} \mathrm{dm}^{-3}\right)$. Mínimo, máximo e média dos 10 solos.

\begin{tabular}{|c|c|c|c|c|c|c|c|}
\hline \multirow[t]{2}{*}{ Micronutriente } & \multirow[t]{2}{*}{ Extrator } & \multicolumn{3}{|c|}{ Antes do $1^{\circ}$ cultivo } & \multicolumn{3}{|c|}{ Após do $3^{\circ}$ cultivo } \\
\hline & & Mínimo & Máximo & Média & Mínimo & Máximo & Média \\
\hline \multirow[t]{3}{*}{$\mathrm{Cu}$} & Mehlich 1 & 0,299 & 4,269 & 1,215 & 0,506 & 8,133 & 2,097 \\
\hline & Mehlich 3 & 1,208 & 1,660 & 1,453 & 1,130 & 7,426 & 2,546 \\
\hline & DTPA-TEA & 0,553 & 3,966 & 1,513 & 0,596 & 10,200 & 2.395 \\
\hline \multirow[t]{3}{*}{$\mathrm{Fe}$} & Mehlich 1 & 13,617 & 758,782 & 261,435 & 10,904 & 239,293 & 116.970 \\
\hline & Mehlich 3 & 104,836 & 944,122 & 461,244 & 94,240 & 555,640 & 309,033 \\
\hline & DTPA-TEA & 20,481 & 741,411 & 242,456 & 14,616 & 348.157 & 153,553 \\
\hline \multirow[t]{3}{*}{$\mathrm{Mn}$} & Mehlich 1 & 4,024 & 251,105 & 74,109 & 0,476 & 64,222 & 18,122 \\
\hline & Mehlich 3 & 4,025 & 142,574 & 27,782 & 0,528 & 81,405 & 19,550 \\
\hline & DTPA-TEA & 1,472 & 112.600 & 33.74 & 0.143 & 59,271 & 13,842 \\
\hline \multirow[t]{3}{*}{$\mathrm{Zn}$} & Mehlich I & 1,744 & 8,762 & 3.574 & 0,588 & 2.500 & 1.346 \\
\hline & Mehlich 3 & 1,762 & 5.577 & 3.057 & 0.793 & 2,627 & 1.484 \\
\hline & DTPA-TEA & 0,700 & 8,286 & 2,234 & 0,298 & 1,844 & 0,914 \\
\hline
\end{tabular}

Tabela 121. Coeficientes de correlação simples entre os extratores utilizados com o conteúdo dos micronutrientes na matéria seca da parte aérea obtidos nos três cultivos. Média de todos os solos.

\begin{tabular}{|c|c|c|c|}
\hline \multirow[t]{2}{*}{ Extratores vs Micros } & \multicolumn{3}{|c|}{ Cultivos } \\
\hline & $1^{\circ}$ cultivo & $2^{\circ}$ cultivo & $3^{\circ}$ cultivo \\
\hline DTPA vs $\mathrm{Cu}$ & $0,780^{*}$ & $0,790^{*}$ & $0,460^{*}$ \\
\hline DTPA vs Fe & $0,439^{*}$ & $0,692 *$ & $0,458^{*}$ \\
\hline DTPA vs Mn & $0,797 *$ & $0,741^{*}$ & $0,617 *$ \\
\hline DTPA vs $\mathrm{Zn}$ & $0,782 *$ & $0,857 *$ & $0,806^{*}$ \\
\hline Mehlich I vs Cu & $0,810^{*}$ & $0,830^{*}$ & $0.530^{*}$ \\
\hline Mehlich 1 vs Fe & $0,620^{*}$ & $0,592 *$ & $0,413^{*}$ \\
\hline Mehlich 1 vs Mn & $0.825^{*}$ & $0,862 *$ & $0,773 *$ \\
\hline Mehlich 1 vs Zn & $0,836^{*}$ & $0,861 *$ & $0.820^{*}$ \\
\hline Mehlich 3 vs Cu & $0,370^{*}$ & $0,800^{*}$ & $0,510^{*}$ \\
\hline Mehlich 3 vs $\mathrm{Fe}$ & $0,512 *$ & $0,677 *$ & $0,580^{*}$ \\
\hline Mehlich 3 vs Mn & $0,662 *$ & $0,737 *$ & $0,614^{*}$ \\
\hline Mehlich 3 vs Zn & $0,742 *$ & $0,781 *$ & $0,721^{*}$ \\
\hline
\end{tabular}

* significativo ao nivel de $5 \%$ de probabilidade.

Após o primeiro cultivo, os coeficientes de correlação entre o teor de $\mathrm{Cu}$ no solo com o teor e conteúdo na planta mostraram um comportamento semelhante para os três extratores estudados, porém, no último cultivo, os coeficientes de correlação entre o teor no solo e na planta foram muito baixos, não se destacando nenhum dos extratores (Tabelas 121 e 122). Entretanto, Abreu et al. (1996), trabalhando com trigo e feijão como 
planta-teste, obtiveram, exceto para o Mehlich 1 no trigo e o DTPA-TEA no feijão, coeficientes de correlação mais elevados, concluindo ser o Mehlich 3 e DTPA-TEA os extratores mais promissores na avaliação do cobre disponivel no solo.

Tabela 122. Coeficientes de correlação simples entre os extratores utilizados com o teores dos micronutrientes na matéria seca da parte aérea obtidos nos três cultivos. Média de todos os solos.

\begin{tabular}{|c|c|c|c|}
\hline \multirow[t]{2}{*}{ Extratores vs Micros } & \multicolumn{3}{|c|}{ Cultivos } \\
\hline & $1^{\circ}$ cultivo & $2^{\circ}$ cultivo & $3^{\circ}$ cultivo \\
\hline DTPA vs $\mathrm{Cu}$ & $0.310^{*}$ & $0,390^{*}$ & $0.010^{\mathrm{ns}}$ \\
\hline DTPA vs Fe & $0.128^{\mathrm{ns}}$ & $0,572 *$ & $0.540^{*}$ \\
\hline DTPA vs Mn & $0.760^{*}$ & $0,834^{*}$ & $0.681^{*}$ \\
\hline DTPA vs $\mathrm{Zn}$ & $0,563 *$ & $0,872 *$ & $0,835^{*}$ \\
\hline Mehlich I vs Cu & $0,331 *$ & $0,420 *$ & $0,089^{\mathrm{is}}$ \\
\hline Mehlich 1 vs Fe & $0,327 *$ & $0,566^{*}$ & $0,580^{*}$ \\
\hline Mehlich 1 vs Mn & $0,778^{*}$ & $0,907^{*}$ & $0,822 *$ \\
\hline Mehlich 1 vs $\mathrm{Zn}$ & $0,680^{*}$ & $0,843^{*}$ & $0,832 *$ \\
\hline Mehlich 3 vs $\mathrm{Cu}$ & $0,170^{\mathrm{ns}}$ & $0,400^{*}$ & $0,050^{\mathrm{ns}}$ \\
\hline Mehlich 3 vs Fe & $0,140^{1 \mathrm{~ns}}$ & $0,502 *$ & $0,613^{*}$ \\
\hline Mehlich 3 vs Mn & $0,651^{*}$ & $0,873 *$ & $0,699 *$ \\
\hline Mehlich 3 vs $Z n$ & $0,518^{*}$ & $0,807^{*}$ & $0.778 *$ \\
\hline
\end{tabular}

${ }^{*}$ significativo ao nivel de $5 \%$ de probabilidade.

${ }^{\text {ns }}$ não significativo

O ferro e o manganês apresentaram comportamento semelhante. Observou-se uma grande variabilidade nos teores desses elementos nos solos (Tabela 120), porém, os coeficientes de correlação entre os teores no solo e o teor e o conteúdo na planta, exceto no DTPA e no Mehlich $3 \mathrm{com} F e$ no primeiro cultivo, foram significativos (Tabela 121 e 122). Esse resultado contraria uma expectativa inicial, visto que Bataglia \& Raij (1989) não encontraram correlações significativas entre os teores desses nutrientes no solo e na planta.

Dentre os três extatores, o Mehlich 3 apresentou maior capacidade de extrair ferro. As concentrações médias desse elemento extraídas pelo Mehlich 3 foram 1,8 e 1,9 vezes maiores do que aquelas extraídas pelo Mehlich 1 e DTPA, respectivamente, no primeiro cultivo. No terceiro cultivo essa diferença acentuou-se, passando para 2,0 e 2,6 vezes maior do que o Mehlich 1 e DTPA, respectivamente (Tabela 120). A 
superioridade do extrator Mehlich 3 na capacidade de extrair Fe, também foi comprovada por Alva (1992) em estudo comparativo das quantidades extraídas por diferentes extratores em 340 amostras de solos da Flórida cultivados com cítrus.

Conforme a revisão de Bataglia \& Raij (1989), entre os micronutrientes metálicos, o $\mathrm{Zn}$ é o nutriente mais estudado no Brasil, principalmente pela frequente ocorrência de deficiência nos nossos solos. Os resultados da Tabela 120 mostram que os extratores ácidos extraíram mais $\mathrm{Zn}$ do solo que o complexante DTPA-TEA, concordando com as observações feitas por Gatti et al. (1991), Paula et al. (1991) e Galrão (1995). Os extratores Mehlich I e Mehlich 3 foram semelhantes entre si na determinação do $\mathrm{Zn}$ disponivel do solo. Mesmo apresentando significância nos três extratores estudados $(\mathrm{P}<0,05)$, os maiores coeficientes de correlação entre o teor de $\mathrm{Zn}$ no solo com o teor e o conteúdo na planta obtidos nos três cultivos foram encontrados com o extrator Mehlich 1 (Tabela 121 e 122). Segundo Machado \& Pavan (1987) as vantagens do uso da solução extratora DTPA para os solos neutros e calcários do Colorado (Lindsay \& Norvell, 1978), foram anuladas nos solos ácidos contendo caulinita como mineral dominante de argila. Os autores concluíram em seus estudos de avaliação de métodos químicos para extração de zinco no solo para mudas de café que os extratores ácidos, Mehlich 1 e $\mathrm{HCl}$, foram os mais eficientes para extração de zinco nos solos com $\mathrm{pH}<5,5$ e os quelatizantes, EDTA e DTPA, para condições de $\mathrm{pH}>6,2$. Resultados semelhantes foram também encontrados por Singh \& Möller, estudando a disponibilidade do $\mathrm{Zn}$, por diferentes extratores, em classes dominantes de solos do trópico úmido brasileiro. Na comparação dos extratores, os autores concluíram que o $\mathrm{Zn}$ extraído pelo Mehlich 1 pode ser predito com grande confiança $\left(R^{2}=0,88\right)$, pela melhor equação ajustada a qual incluiu o carbono orgânico, argila, fósforo disponivel e zinco total.

As Figuras de 1 a 12 mostram a relação entre os extratores Mehlich 1, Mehlich 3 e DTPA e os coeficientes de determinação $\left(\mathrm{R}^{2}\right)$ para os micronutrientes $\mathrm{Cu}, \mathrm{Fe}$, $\mathrm{Mn}$ e $\mathrm{Zn}$ nos diferentes solos estudados (os solos foram agrupados em seis tipos dominantes). Observa-se para o Mn e o $\mathrm{Zn}$, que apesar das diferenças já citadas, os extratores, entre si, apresentaram correlações significativas, independentemente do tipo de 
solo (Figuras 2, 4, 6, 8, 10 e 12). Essa similaridade é confirmada pela elevado grau de correlação obtido entre os três extratores nos seis tipos de solos. Esses resultados são corroborados por diversos trabalhos (Camargo et al., 1982; Sims, 1985; Bataglia \& Raij, 1989; Wendt, 1995; Accioly et al., 1996).

Para o cobre, as soluções extratoras contendo um agente quelante asseguram, normalmente, maior eficiência na extração desse elemento, devido à maior parte do cobre no solo estar complexada pela matéria orgânica (Loué, 1993). Verifica-se, portanto, no caso do cobre no latossolo húmico antropogênico, por apresentar alto teor de matéria orgânica (Tabela 6), que as correlações entre os teores extraídos pelos extratores Mehlich 1 e DTPA e entre Mehlich 1 e Mehlich 3 não foram significativas (Figura 9), porém, os extratores Mehlich 3 e DTPA-TEA apresentaram alto coeficiente de correlação $\left(0,76^{*}\right)$. Esta similaridade se deve ao fato de ambas as soluções extratoras conterem agentes complexantes que extraem o $\mathrm{Cu}$ retido na matéria orgânica. Resultados semelhantes foram observados por Walworth et al. (1992) e Abreu et al. (1996), que obtiveram com os extratores Mehlich 3 e DTPA-TEA, altos coeficientes de correlação $(0,73 *$ e $0,99 *$, respectivamente).

Os valores de $\mathrm{Fe}$ extraídos pelas três soluções foram semelhantes aos obtidos por Bataglia e Raij (1989) com os extratores Mehlich 1 e DTPA-TEA, por Wendt (1995) com os extratores Mehlich 3 e DTPA-TEA. Observou-se apenas nos solos podzóis, aluvial e podzólico vermelho-amarelo maior grau de associação entre os extratores Mehlich 1 e Mehlich 3, com coeficientes de determinação significativos (Figuras 1, 5 e 11). Nos latossolos e nos podzólicos amarelos todas as relações entre os extratores para ferro apresentaram coeficientes de determinação significativos (Figuras 1, 3 e 9). 


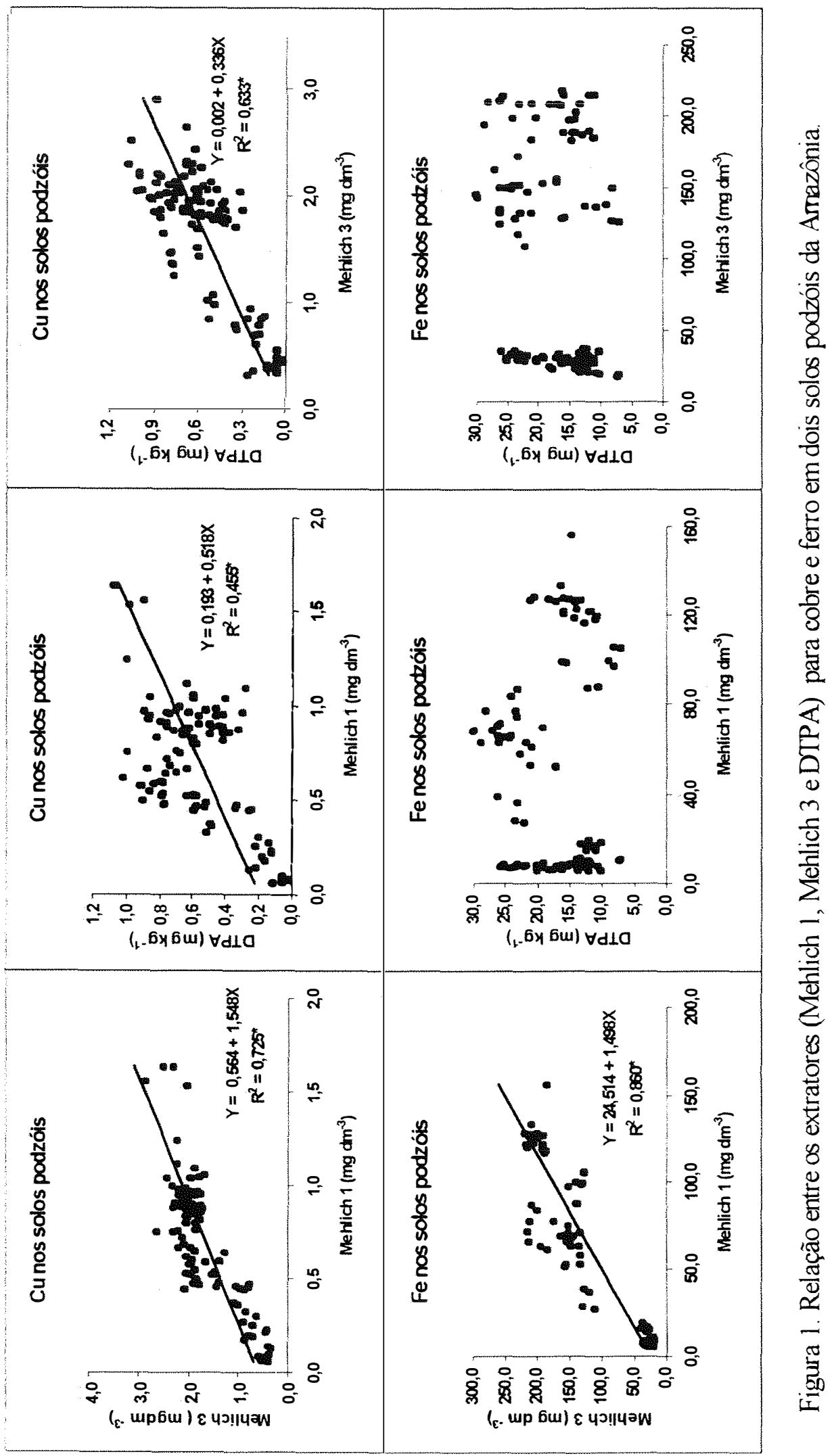




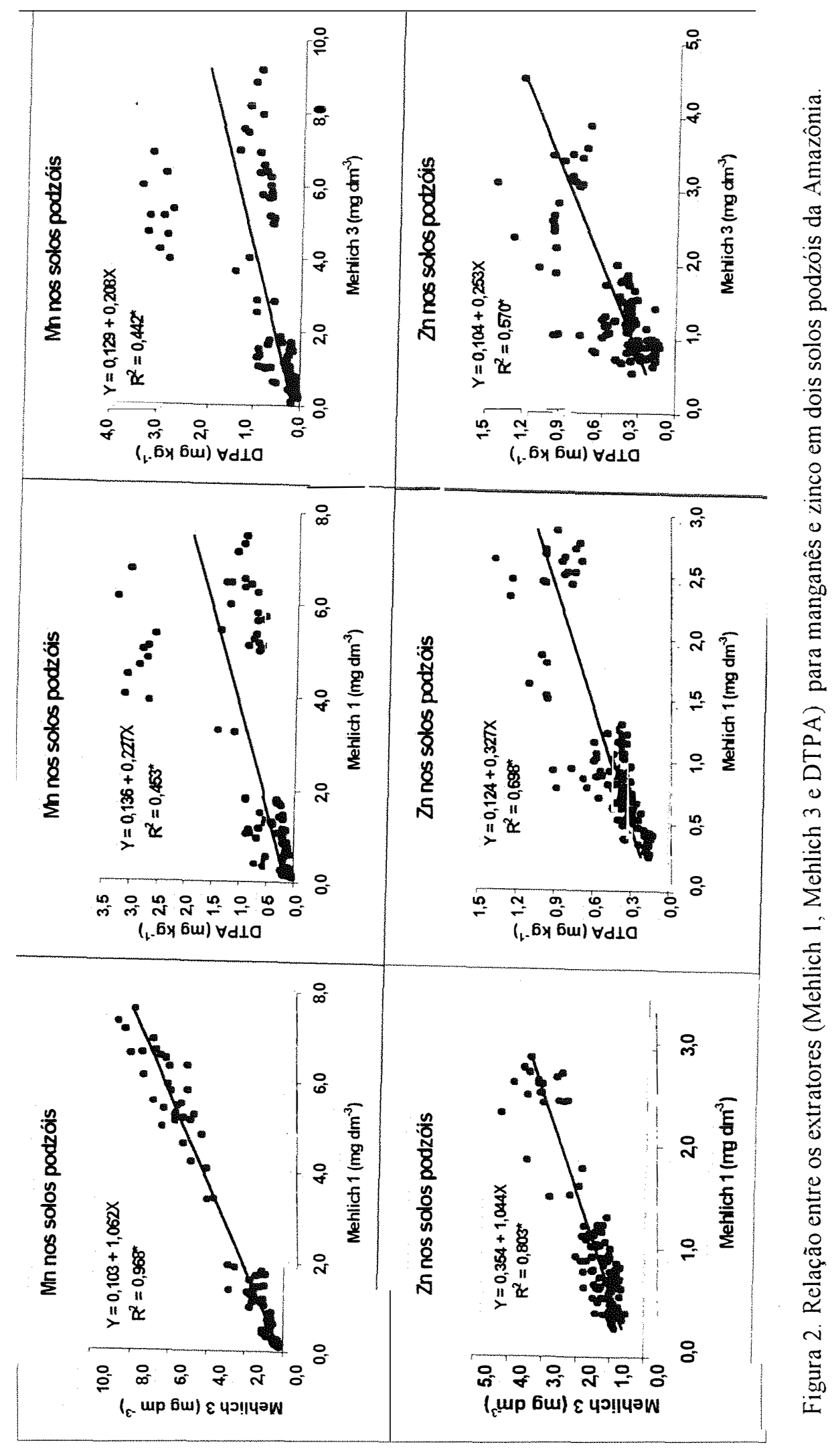




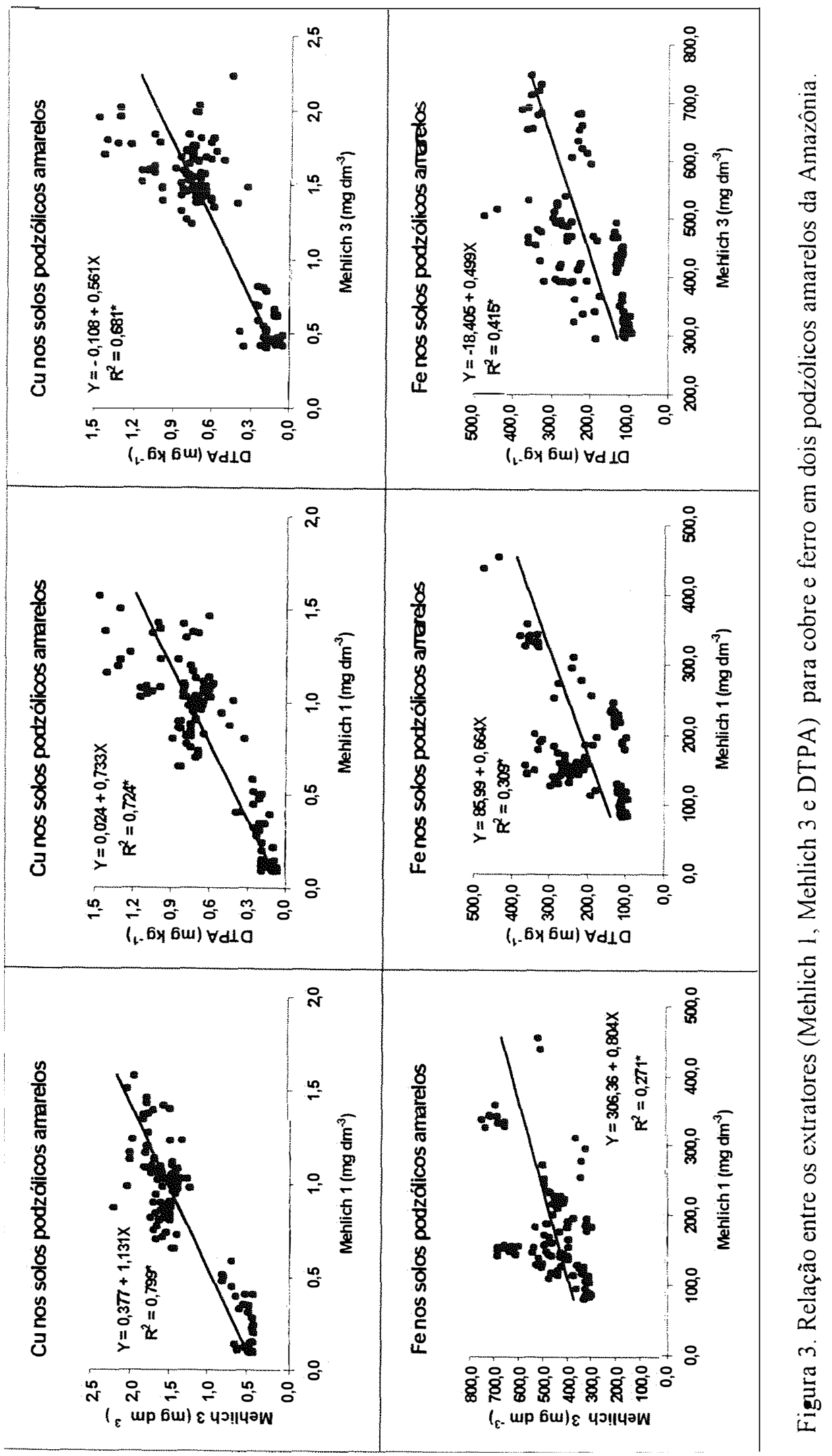




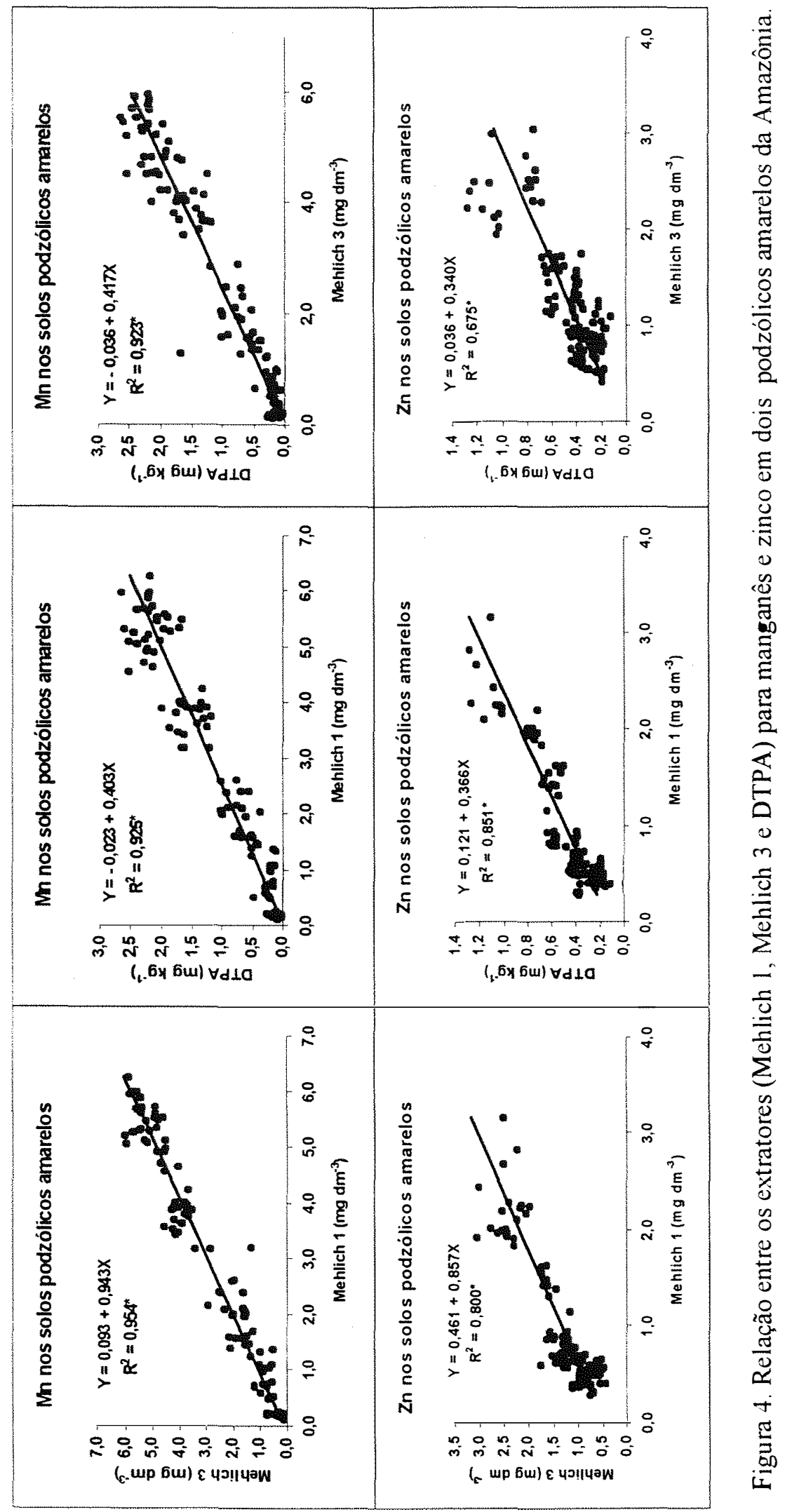




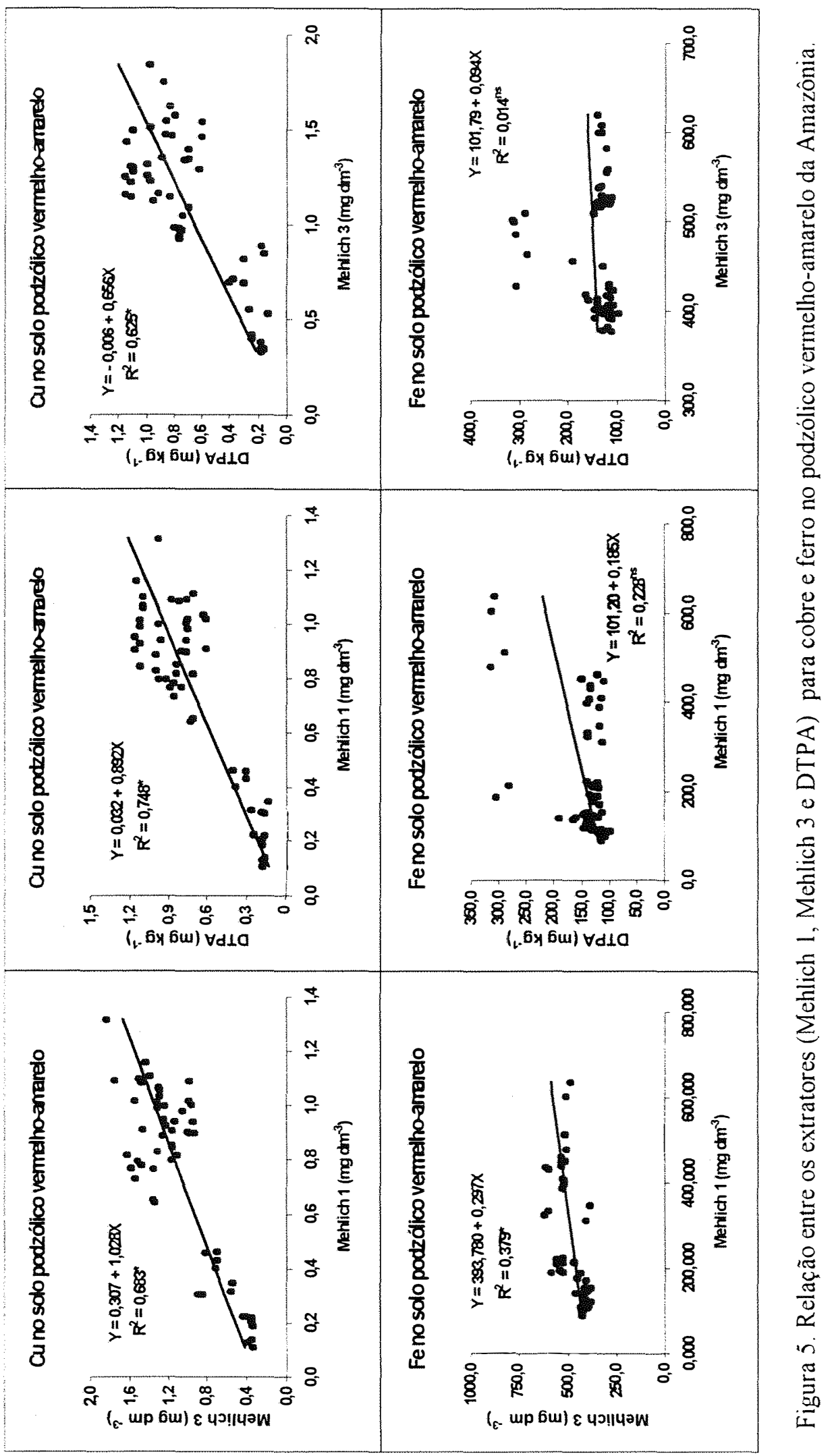




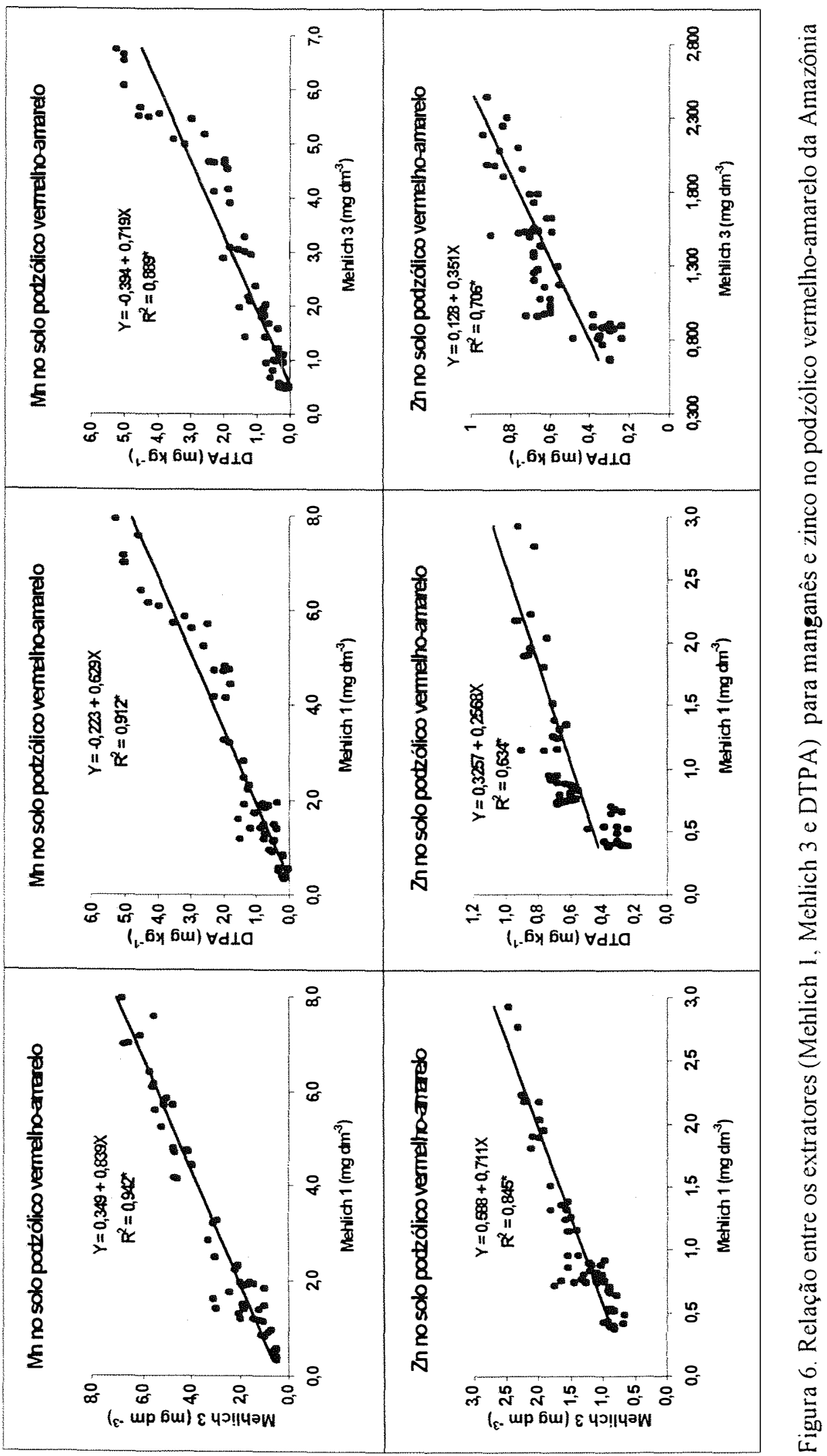




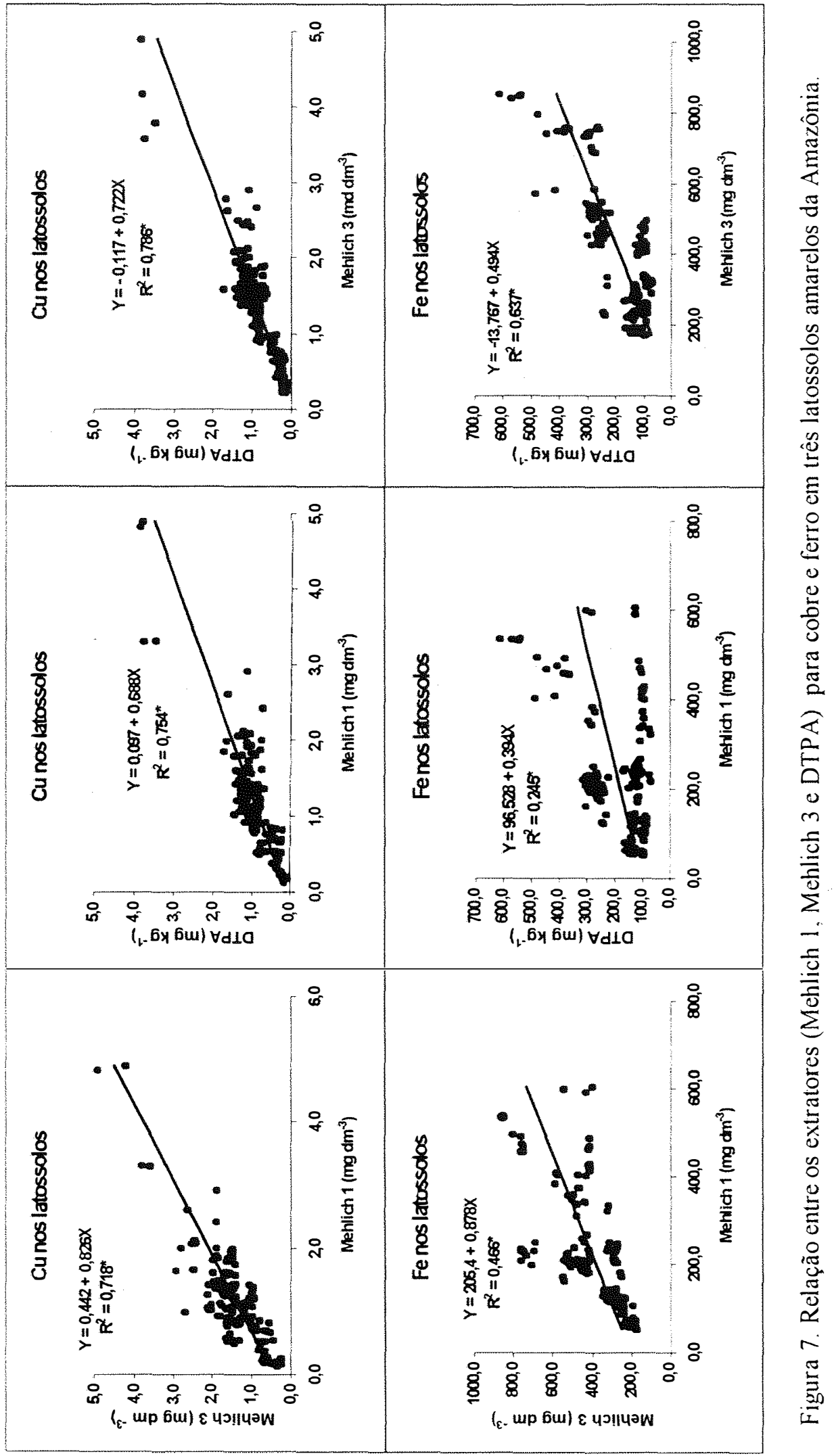




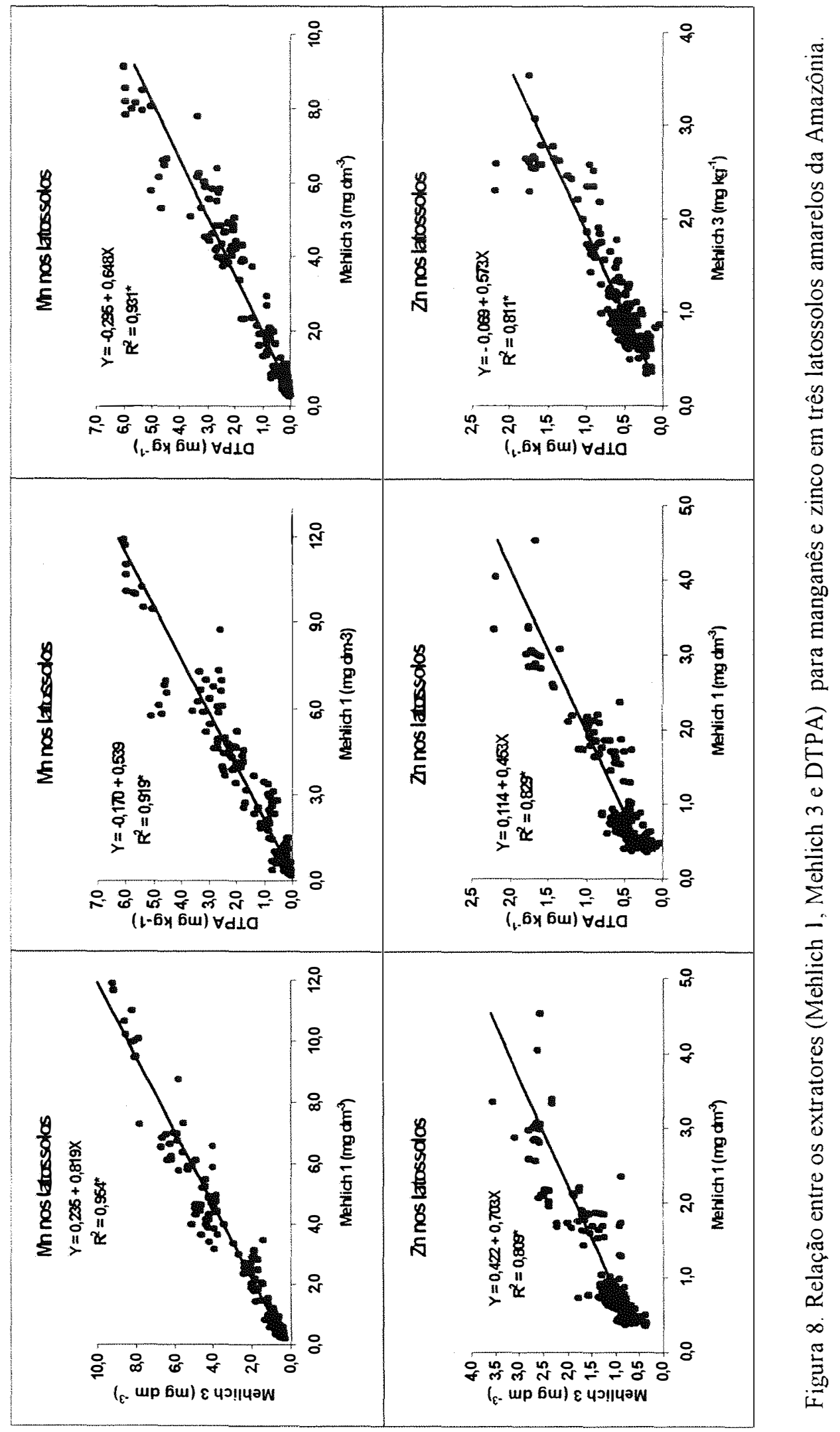




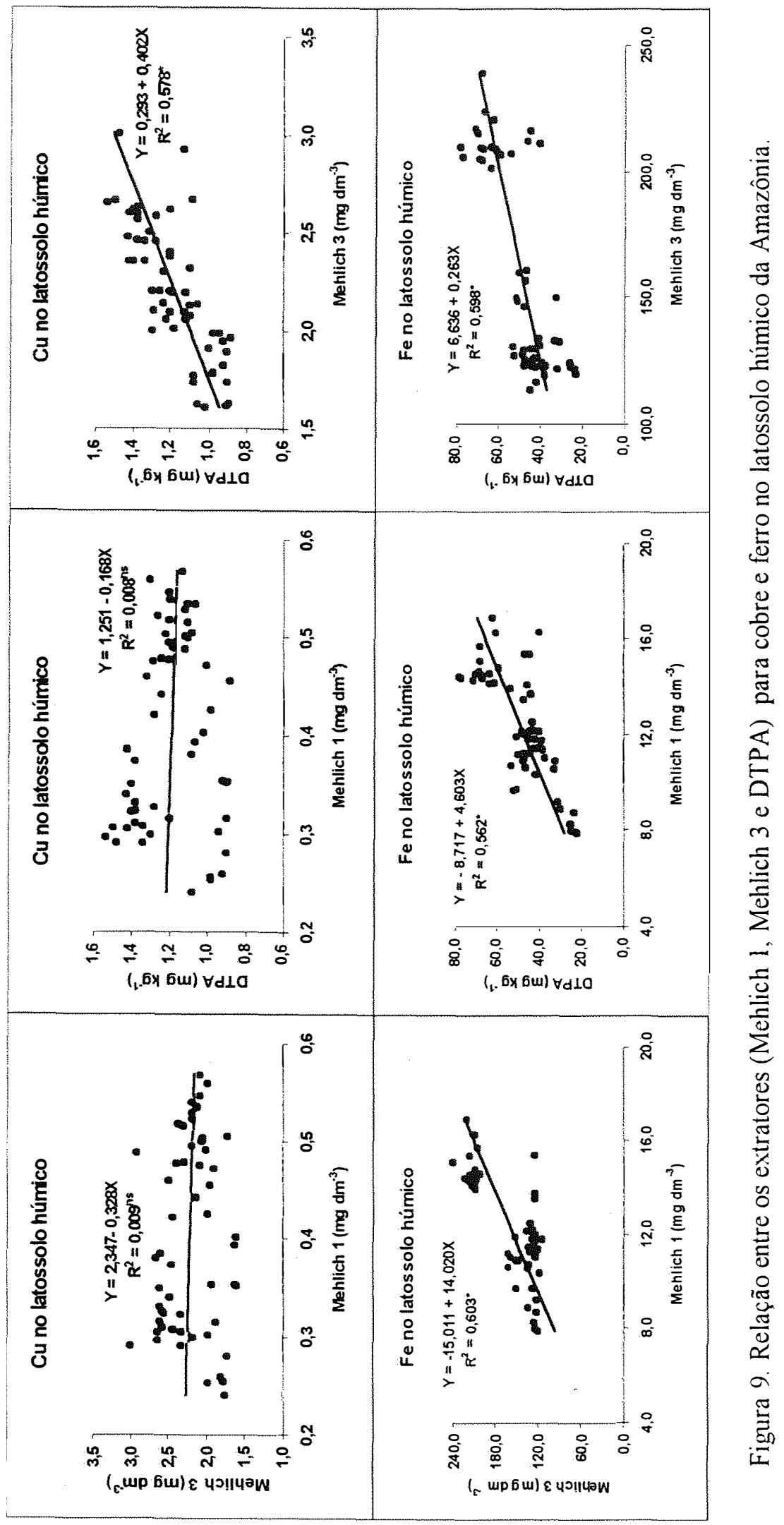




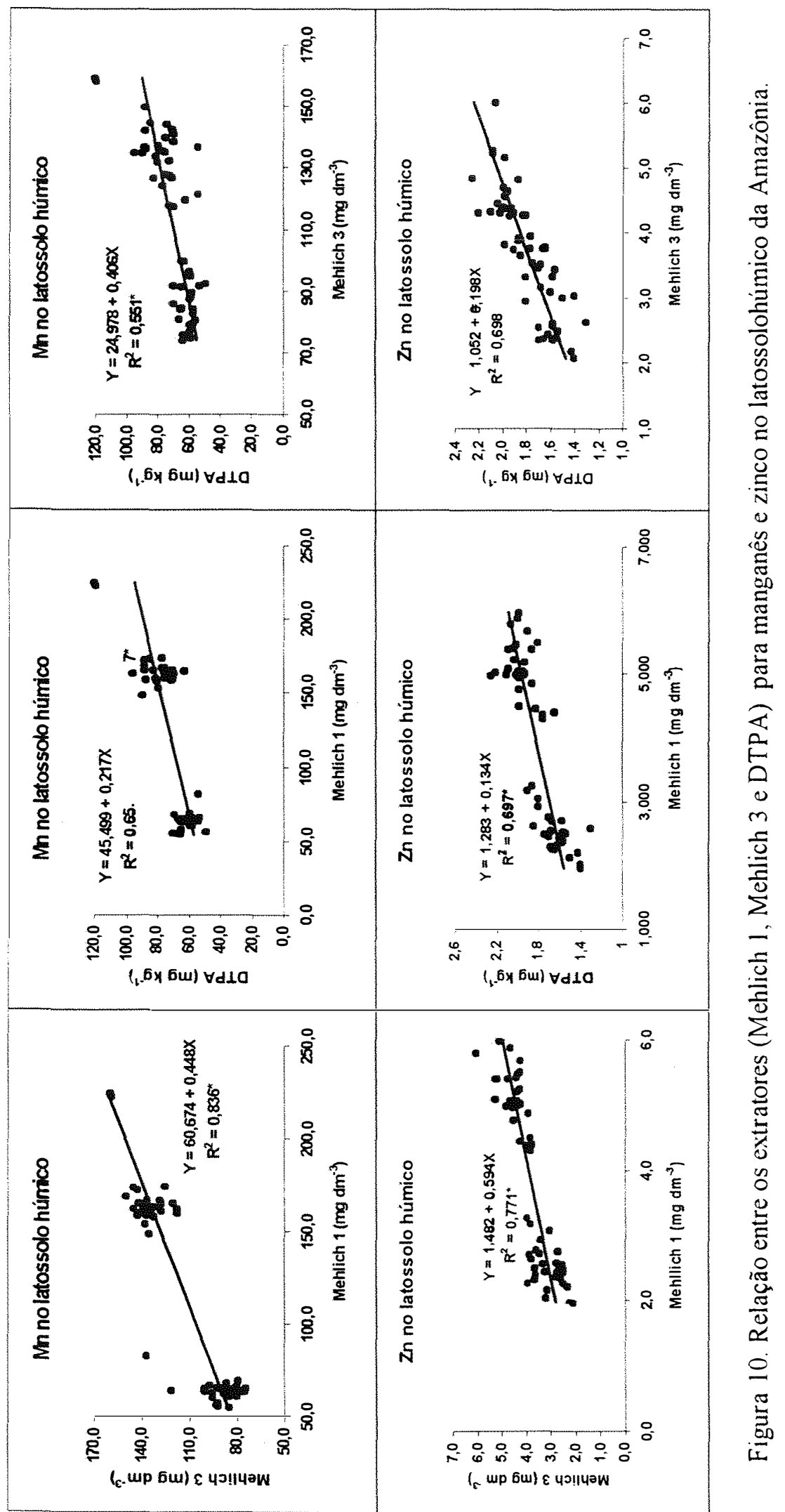




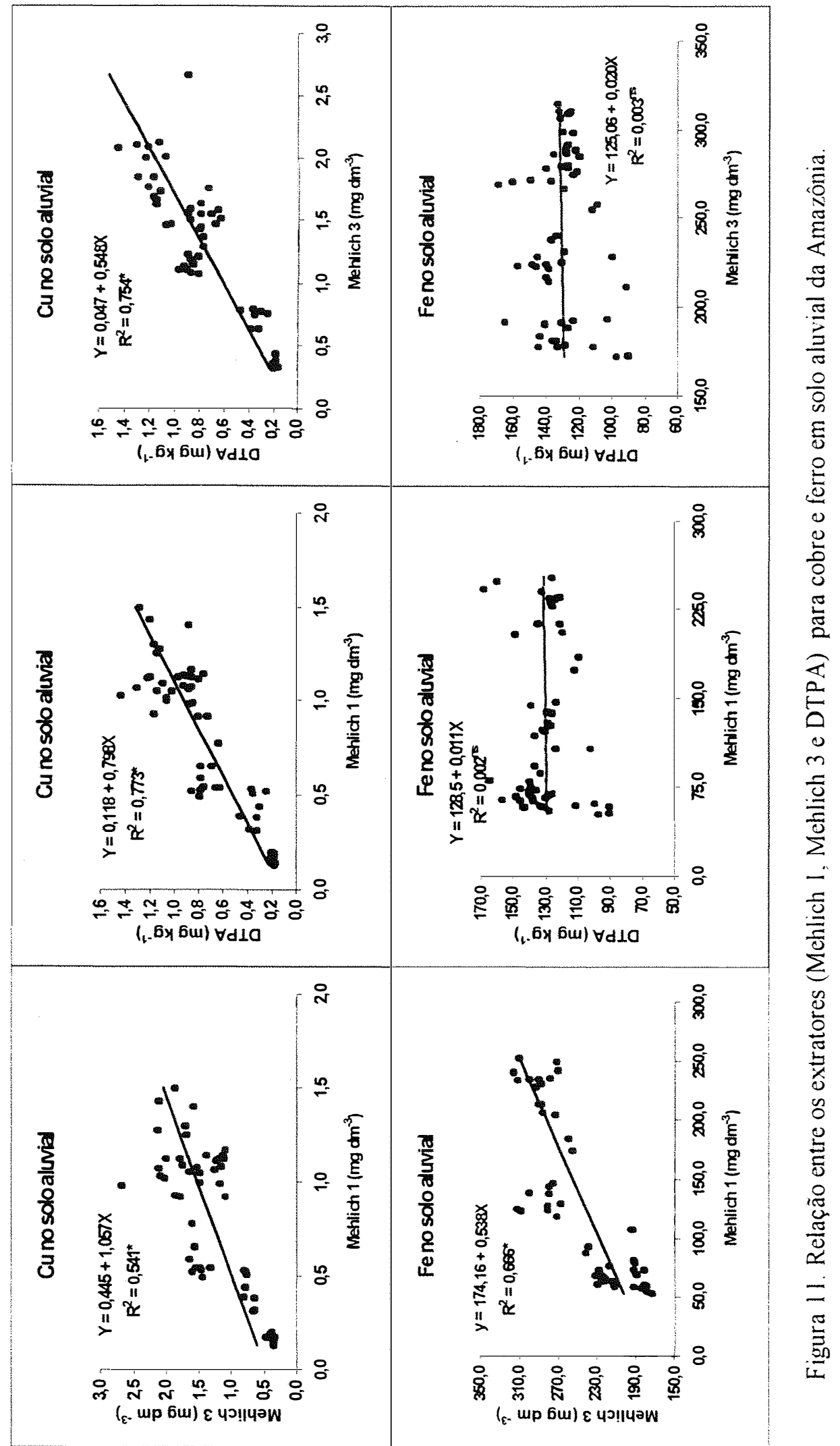




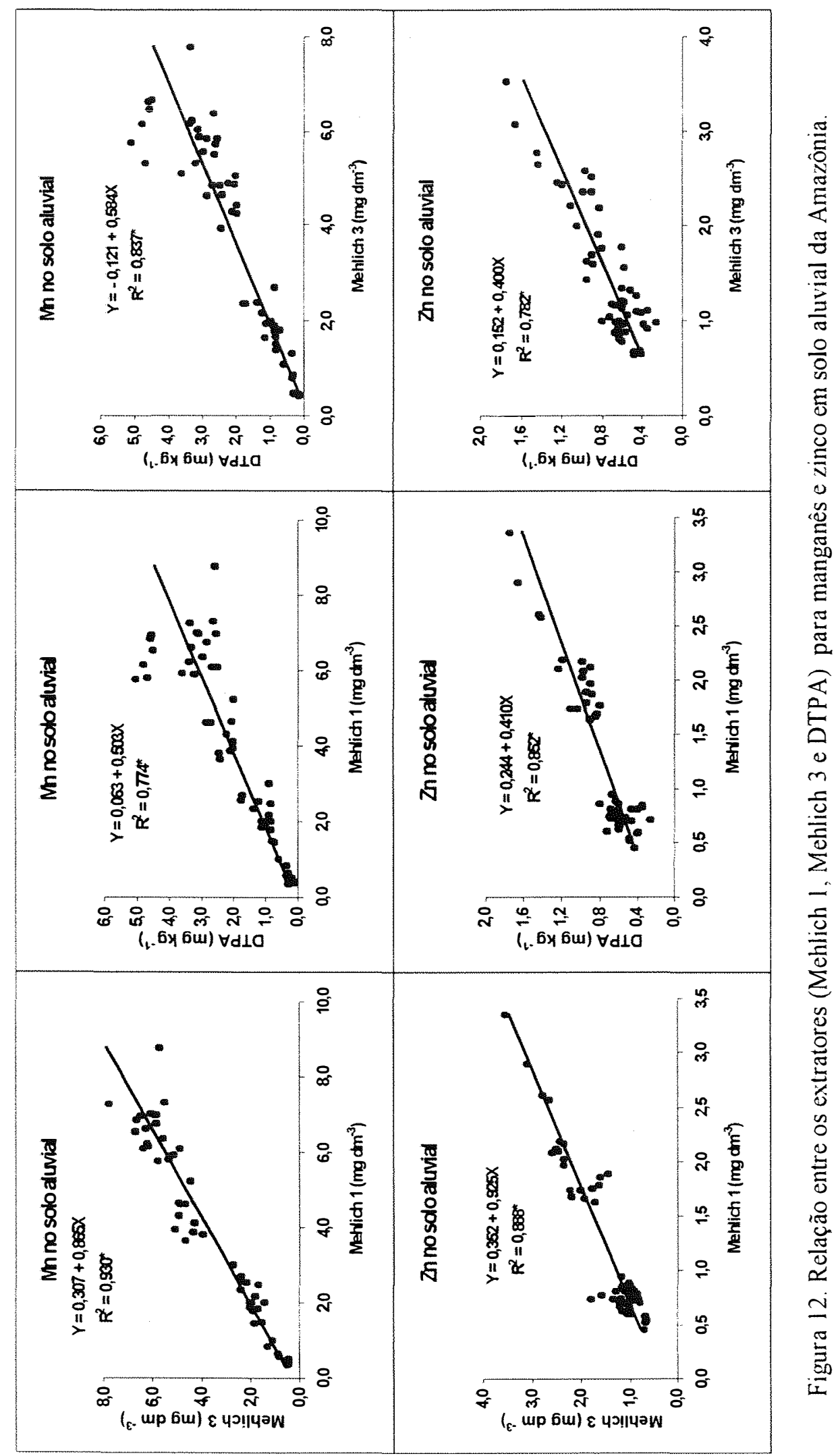




\section{CONCLUSÕES}

Através dos resultados obtidos pode-se concluir que:

a) A pouca resposta à omissão dos micronutrientes sugere que a maior limitação à produtividade dos solos da Amazônia ainda não cultivados seja devida aos baixos teores de macronutrientes e à acidez.

b) Respostas significativas observadas principalmente para $\mathrm{Cu}$, Mo e $\mathrm{Zn}$ aumentaram no terceiro cultivo, sugerindo que o uso continuado desses solos possa levar ao aparecimento de deficiências de micronutrientes.

c) Dentre os solos estudados, a maior fertilidade do AL e do LH foi confirmada pelos teores totais e disponíveis mais elevados dos nutrientes associado às maiores produções de matéria seca do arroz.

d) A capacidade de extração das diversas soluções, Mehlich 1 e 3 e DTPA variou em função dos solos; entretanto, o extrator Mehlich 1 mostrou, de modo geral, os melhores coeficientes de correlação entre os teores dos elementos no solo e o seu conteúdo na planta. 


\section{REFERÊNCIAS BIBLIOGRÁFICAS}

ABREU, C.A., RAIJ, B. van; ABREU, M.F.; SANTOS, W.R.; ANDRADE, J.C. Efficiency of multinutrient extractants for the determination of available copper soils. Communications in Soil Science and Plant Analysis, v.27, p.763-71, 1996.

ABREU, C.A.; ABREU,M.F.; RAIJ, B. van; BATAGLIA,O.C.; ANDRADE, J.C. Extraction of boron from soil by microwave heating for ICP-AES determination. Communications in Soil Science and Plant Analysis, v.25, p.3321-33, 1994.

ACCIOLY, A.M.A.; FURTINI NETO, A.E.; GUEDES, A.A. Comparação de extratores para avaliação de metais pesados. In: REUNIÃO BRASILEIRA DE FERTILIDADE DO SOLO E NUTRIÇÃO MINERAL DE PLANTAS, 22., Manaus, 1996, Manaus. Resumos expandidos... Manaus: EMBRAPA/SBCS, 1996. p.212-3.

ALVA, A.K. Micronutrients status of Florida soils under citrus production. Communications in Soil Science and Plant Analysis, v.23, p.2493-510, 1992.

ARKCOLL, D. Algumas considerações adicionais sobre adubação na Amazônia. Curso de Atualização em Fertilidade do Solo - Amazônia Ocidental. Manaus, 1982. (mimeo).

BARBOSA FILHO, M.P.; DYNIA, J.F.; ZIMMERMANN, F.J.P. Resposta do arroz de sequeiro ao zinco e ao cobre com efeito residual para o milho. Revista Brasileira de Ciência do Solo, v. 14, p.333-338, 1990.

BARBOSA FILHO, M.P.; Nutrição e adubação do arroz; sequeiro e irrigado. Piracicaba, Instituto Brasileiro para Pesquisa da Potassa e do Fosfato, 1987. 129p. 
(Boletim Técnico, 9).

BARTZ, H.R. \& MAGALHÃES, A.F. Avaliação da disponibilidade de boro através de soluções extratoras em alguns solos do Rio Grande do Sul. Agronomia Sulriograndense, Porto Alegre, v. 11, p.86-96, 1975. Soil Scienci Society American Journal, v.43, p.75-78, 1979.

BATAGLIA, O.C. \& RAIJ, B. van. Eficiência de extratores na determinação de boro em solos. Revista Brasileira de Ciência do Solo, v. 14, p.25-31, 1990.

BATAGLIA, O.C. \& RAIJ, B. van. Extratores de micronutrientes da análise do solo. In: REUNIÃO BRASILEIRA DE FERTILIDADE DO SOLO, 18, Guarapari, 1988. Resumos... Guarapari, SEAG-ES/EMCAPA/EMATER-ES/SBCS, 1988. p.64.

BATAGLIA, O.C. Micronutrientes: Disponibilidade e interações. In: SIMPÓSIO DE ENXOFRE E MICRONUTRIENTES NA AGRICULTURA BRASILEIRA, 1, Londrina, 1988. Anais... Londrina, EMBRAPA-CNPSo/ IAPAR/SBCS, 1988 p. 121-32.

BATAGLIA, O.C.; RAIJ, B. van. Eficiência de extratores de micronutrientes na análise de solo. Revista Brasileira de Ciência do Solo, v. 13, p.205-12, 1989.

BERGER, K.C. \& TRUOG, E. Boron determination in soils and plants using the quantization reaction. Industrial and Engineering Chemistry, v.11, p.540-5, 1939.

BERGMANN, W. Nutritional Disordens of Plants: development, visual and analytical diagnosis. Gustav Fischer. New York. 1992. cap. 4, p. 86-332. 
BLAKE, G.R. Particle density. In: BLACK, C.A., ed. Methodos of soil analysis; physical and mineralogical properties, incluing statistics of measurement and sampling, Madison, American Society of Agronomy, 1965. pt.1, Cap. 29, p.371-3. (Agronomy, 9).

BOYER, J. Les Sols Ferrallitiques: facteurs de fertilité et utilisation des sols. Paris ORSTOM, 1982. 384p. (Initiations-Documentations Techniques, 52)

BRITTO, D.P.P. de S ; CASTRO, A.F. de; COSTA, F.A.; NERY, C. Ensaio de adubação de milho em Latossolo Vermelho-Amarelo sob vegetação decerrado. Pesquisa Agropecuária Brasileira, v.6, p.203-7, 1971.

BUZETTI, S. Estudo da eficiência de extratores químicos de zinco, no solo, para milho. Revista Brasileira de Ciência do Solo, v.16, p.367-372, 1992

CAMARGO, O.A. Micronutrientes no solo. In: SIMPÓSIO DE ENXOFRE E MICRONUTRIENTES NA AGRICULTURA BRASILEIRA, 1, Londrina, 1988. Anais... Londrina, EMBRAPA-CNPSo/ IAPAR/SBCS, 1988. p.103-20.

CAMARGO, O.A.; MONIZ, A.C.; JORGE, J.A.; VALADARES, J.M.A.S. Métodos de análise química, mineralógica e física de solos do Instituto Agronômico de Campinas. Campinas, Instituto Agronômico, 1986. (Boletim Técnico, 106).

CAMARGO, O.A.; VALADARES, J.M.A.S.; DECHEN, A.R. Efeitos do pH e da incubação na extração do manganês, zinco, cobre e ferro do solo. Revista Brasileira de Ciência do Solo, v.6, p.83-8, 1982.

CATANI, R.A.; ALCARDE, J.C.; FURLANI, P.R.A determinação do teor total e do teor solúvel, em diversas soluções, de molibdênio do solo. Anais da E.S.A. "Luiz de 
Queiroz".v.27, p.171-180, 1970.

CORRÊA, J.C.; BASTOS, J.B. Os solos das várzeas do Paraná dos Ramos (município de Barreirinha-Amazonas) e sua fertilidade. Manaus: EMBRAPA-UEPAEManaus, 1982. 26p. (EMBRAPA-UEPAE-Manaus. Boletim de Pesquisa, 1).

COSTA, M.P. Efeitos da matéria orgânicas em alguns atributos do solo. Piracicaba, 1983. 173p. (M.S.) - Escola Superior de Agricultura "Luiz de Queiroz"/USP.

CRAVO, M.S.; SMYTH, T.J. Sistema de cultivo com altos insumos na Amazônia Brasileira. In: II TALLER LATINOAMERICANO DE MANEJO DE SUELOS TROPICALES, San José, Costa Rica. 1991. Manejos de suelos tropicales en Latinoamerica. Soil Science Department, North Carolina State University, Raleigh, NC 27695-7619, USA, 1991. p. 144-156.

CRUZ, M.C.P. \& FERREIRA, M.E. Seleção de métodos para avaliação de boro disponivel em solos. Pesquisa Agropecuária Brasileira, v. 19, p. 1457-64, 1984.

DEMATTÊ, J.L.I. Manejo de solos ácidos dos trópicos úmidos - Região Amazônica. Campinas: Fundação Cargill, 1988. 215p.

DROSDOFF, M. Microelementos del suelo. In DROSDOFF, M. AUBERT, G.; COULTER, J.K. e otros. Suelos de las regiones tropicales húmedas. Buenos Aires: Edisiones Marymar. 1975. p. 187-200.

EMPRESA BRASILEIRA DE PESQUISA AGROPECUÁRIA. Centro Nacional de Pesquisa de Solos. Manual de métodos de análise de solo. Rio de Janeiro. 1997. 212p. (EMBRAPA-CNPS. Documentos, 1). 
EMPRESA BRASILEIRA DE PESQUISA AGROPECUÁRIA. Fertilidade do solo de terra firme. In: Relatório Técnico Bienal da Unidade de Execução de Pesquisa de Âmbito Estadual de Manaus. 1982 - 1983. 1984. p.49-104.

EMPRESA BRASILEIRA DE PESQUISA AGROPECUÁRIA. Serviço Nacional de Levantamento e Conservação do Solo. Manual de métodos de análise do solo. Rio de Janeiro, 1979. n.p.

EMPRESA BRASILEIRA DE PESQUISA AGROPECUÁRIA. Solos. In: Relatório Técnico Bienal da Unidade de Execução de Pesquisa de Âmbito Estadual de Manaus. 1984 - 1985. 1989. p. 197-279.

FITTS, J.W.; NELSON, W.L. The determination of lime and fertilizer requirements of soil through chemical tests. Advances in Agronomy, v.8, p.241-82, 1956.

GALRÃO, E.Z. \& MESQUITA FILHO, M.V. de. Efeito de micronutrientes na produção e composição química do arroz (Oryza sativa L.) e do milho (Zea mays L.) em solo de cerrado. Revista Brasileira de Ciência do Solo, v. 5, p.72-75, 1981.

GALRÃO, E.Z. Efeito de micronutrientes e do cobalto na produção e composição química do arroz, milho e soja em solo de cerrado. Revista Brasileira de Ciência do Solo, v.9, p.111-116, 1984.

GALRÃO, E.Z. Níveis críticos de zinco para o milho cultivado em latossolo vermelhoamarelo, fase cerrado. Revista Brasileira de Ciência do Solo, v.19, p.255-260, 1995.

GALRÃO, E.Z.; SUHET, A.R.; DE SOUZA, D.M.G. Efeito de micronutrientes no rendimento e composição química do arroz (Oryza sativa L.) em solo de cerrado. 
Revista Brasileira de Ciência do Solo, v.2, p. 129-132, 1978.

GOMES, F.P. A estatística moderna na agricultura. 2.ed. Piracicaba: POTAFOS, 1985. 162p.

GRAHAM, R.D.; NELCH, R.M.; GRUNES, D.L.; CARY, E.E.; NORVEL, W.A. Effect of zinc deficiency on the acumulation of boron and and other mineral nutrients in barley. Soil Science Society of American, v. 51, p.652-7, 1987.

GRIGG, J.L. Determination of available molybdenum of soils. New Zeland journal of Science and Technology, Wellington, v.34, p.405-14, 1953.

GUPTA, U.C. A simplified method for determining hot water soluble boron in podzol soils. Soil Science, v. 103, p.424-28, 1967.

HAQUE, I.; OFRLL, R.T.; WALKER, W.M.; KAMARA, C.S. Micronutrient cation survey of lowland rice in sierra leone. Communications in Soil Science and Plant Analysis, v. 10, p.981-992, 1979.

HAUSER, G.F. The calibration of soil tests for fertilizer recommendations. Roma: FAO, 1973. $71 \mathrm{p}$.

JACKSON, M.L. Soil chemical analysis: advanced course. $2^{\underline{a}}$ ed. Madison: s. ed., 1979. 895p.

JN U.Y.; MARTINS, D.C.; ZALAZNY, L.W. Plant availability of applied and native boron in soils with diverse properties. Plant and Soil, v. 105, p. 127-32, 1988.

JORDAN, C.F. Ciclagem de nutrientes e silvivultura de plantações na bacia Amazônica. 
In: ROSAND, P.C. ed. Reciclagem de nutrientes e agricultura de baixos insumos nos trópicos. Ilheus. CEPLAC, 1985. p.186-202.

JORDAN, C.F. Soil of the Amazon Rainforest. In: PRANCE, G.T. \& LOVEJOY,T.E. Amazônia. Key enviroments. Press. Oxford: Pergamon, 1987. p.83-94.

JUNUS, M.A.; COX, F.R. A zinc soil test calibration based upon Mehlich 3 extractable zinc, $\mathrm{pH}$, and cation exchange capacity. Soil Science Society of American Journal, v.51, p.678-83, 1987.

KARIMIAN, N.; COX, F.R. Adsorption and extractability of molybdenum in relation to some chemical properties of soil. Soil Science Society of American Proceedings, v.42, p.757-61, 1978.

KITAKAWA, Y. \& MÖLLER, M.R.F. Clay mineralogy of some typical soil in the Brazilian Amazon region. Pesquisa Agropecuária Brasileira, v.14, p.201-28, 1977.

KITAKAWA, Y. \& MÖLLER, M.R.F. Clay mineralogy of the Terra Roxa Estruturada soil from forest/savannah in the Amazon region. Soil Science Plant Nut., v.25, p.391-405. 1979.

KUBOTA, J. \& CARY, E.E. Cobalt, molybdenum and selenium. In: PAGE, A.L.; MILLER, R.H. \& KEENEY, D.R. (ed.). Methods of soil analysis, 2ª edição Madison, American Society. of Agronomy, 1982. pt.2, p.485-500 (Agronomy, 9).

LIMA FILHO, O.F. de. Calibração de boro e zinco para o cafeeiro (Coffea arabica L. cv. Catuai Amarelo). Piracicaba, 1991. 100p. Dissertação (M.S.) - Centro de Energia Nuclear na Agricultura, Universidade de São Paulo. 
LINDSAY, W.L. \& COX, F.R. Micronutrient soil testing for the tropics. In: VLEK, P. L. G. Micronutrients in tropical food crop production; Developments in plant and soil sciences. Dordrecht: Martinus Nighoff, 1985. v. 14, p. 169-200.

LINDSAY, W.L. \& NORVELL, W.A. Development of a DTPA test for zinc, iron, manganese and copper. Soil Science American Journal, v.42, p.421-428, 1978.

LOPES, A.S. \& CARVALHO, J.G. Micronutrientes: Critério de Diagnose para solos e plantas, correção de deficiências e excessos. In: SIMPÓSIO DE ENXOFRE E MICRONUTRIENTES NA AGRICULTURA BRASILEIRA, 1, Lodrina, 1988. Anais... Londrina, EMBRAPA-CNPSo/IAPAR/SBPS, 1988. p.133-78.

LOPES, A.S. A survey of the fertility status of soils under "cerrado" vegetation in Brazil.. Raleigh, USA., 1975. 138p. Thesis (M.S.) North Carolina State University.

LOPES, A.S. Uso eficiente de fertilizantes com micronutrientes. In: SIMPÓSIO SOBRE FERTILIDADE NA AGRICULTURA BRASILEIRA, Brasília, 1984. Anais.. Brasilia, EMBRAPA-DEP, 1984. (EMBRAPA-DEP. Documentos, 14).

LOUÉ, A. Oligo-éléments en agriculture. Paris: Éditions Nathan. 1993. 577p.

MACHADO, P.L.O.A.; PAVAN, M.A. Avaliação de métodos químicos para extração de zinco disponivel no solo para mudas de café. Pesquisa Agropecuária Brasileira, v.22, p.213-7, 1987.

MACKAY, D.C.; CHIPMAN, E.V.; GUPTA, V.C. Copper and molybdenum nutrition of crops grown on acid sphagnum peat soil. Soil Science Society of American Proceedings, v.30, p.755-59, 1966. 
MAHLER, R.L.; NAYLOR, D.V.; FREDRICKSON, M.K. Hot water extraction of boron from soils using sealed plstic pouches. Communications in Soil Science and Plant Analysis, v. 15, p.479-92, 1984.

MALAVOLTA, E. Elementos de nutrição mineral de plantas. São Paulo: Editora Agronômica Ceres Ltda. 1980. $251 \mathrm{p}$.

MALAVOLTA, E. Fertilidade dos solos da Amazônia. In: VIEIRA, L.S \& SANTOS, P.C.T. eds. Amazônia: seus solos e outros recursos naturais. São Paulo: Editora Agronômica Ceres Ltda, 1987. p.374-416.

MALAVOLTA, E. Fertilizantes e seu impacto ambiental: micronutrientes e metais pesados, mitos, mistificação e fatos. São Paulo:. Produquímica, 1994. 153p.

MALAVOLTA, E. Manual de química agrícola. São Paulo: Editora Agronômica Ceres Ltda. 1976. cap. 12, p. 413-452.

MALAVOLTA, E.; FORNASIERI FILHO, D. Nutrição mineral. In: FERREIRA, M.E.; YAMADA, T.; MALAVOLTA E. (Ed.). Cultura do arroz de sequeiro: fatores afetando a produtividade. Piracicaba: Instituto da Potassa \& Fosfato, 1983. cap.2, p. $95-144$.

MalaVolta, E.; MURAOKA, T.; BOARETTO, A. E. Avaliação da fertilidade do solo pela técnica do diagnóstico por subtração. Piracicaba-SP, CENA-USP. 1993. (Apontamentos de aula).

MALAVOLTA, E.; VITTI, G.C.; OLIVEIRA, S.A. Avaliação do estado nutricional das plantas: princípios e aplicações. Piracicaba: POTAFOS, 1997, 319p. 
MAlAVOlTA, E.; VITTI, G.C.; OlIVEIRA, S.A. de. Avaliação do estado nutricional das plantas: princípios e aplicações. Piracicaba, POTAFOS, 1989. $201 \mathrm{l}$.

MEHLICH, A. Mehlich 3 soil test extractant: a modification of Mehlich 2 extractant. Communications in Soil Science and Plant Analysis, v. 15, p. 1409-16, 1984.

MEHLICH, A. New extractant for soil test evaluation of phosphorus, potassium, magnesium, calcium, sodium, manganese and zinc. Communications in Soil Science and Plant Analysis, v.9, p.477-92, 1978.

MÖLLER, M.R.F. Mineralogia de argilas de solos da região Amazônica brasileira. In: SIMPÓSIO DO TRÓPICO ÚMIDO, 1, Belém, 1984. Anais... Belem, EMBRAPACPATU, 1986, v.1, p.214-223.

NICHOLAIDES, J.J.; SÁNCHEZ, P.A.; BANDY, D.E.; VILLACHICA, J.H.; COUTU, A. J. and VALVERDE, C.S. Crop production systems in the Amazon Basin. In: MORAN, E.F. (ed.) The Dilemma of Amazonia Development. Westview Press, Inc. 1983 , p.101-154.

OLSEN, S.R. Micronutrient interactions. In: MORTVEDT, J.J.; GIORDANO, P.M.; LINDSAY, W.L., ed. Micronutrients in agriculture. Mandison: Soil Science Society of America, 1972. P.243-64.

PACHECO, A.R.; BARNWELL, I.M.; TAILLIEZ, B.J. Des cas de déficience en cuivre en pépinière de palmiers a huile en Amazonia brésilienne. Oléagineux, v.41, p.483-9, 1986.

PATHAK, A.; SHANKAR, N.H.; MISRA, R.R. Corrlation of available molybdenum values obtained by different methods of molybdenum uptake by alfafa. Journal of the India Society of Soil Science, v. 17, p. 151-3, 1969. 
PAULA, M.B. de; CARVALHO, J.G.; NOGUEIRA, F.D.; MESQUITA, H.A Curva de resposta e avaliação de extratores para zinco disponivel em solos hidromórficos e aluviais sob arroz inundado. Revista Brasileira de Ciência do Solo. v. 15, p.49-55, 1991.

PIMENTEL-GOMES, F. Curso de estatística experimental, São Paulo: Nobel, 1990. $468 \mathrm{p}$.

QUAGGIO, J.A; RAIJ, B. van. Comparação de métodos rápidos para a determinação da matéria orgânica em solos. Revista Brasileira de Ciência do Solo. v.3, p.184-187, 1979.

RAIJ B. van; QUAGGIO, J.A.; CANTARELLA, H.; FERREIRA, M.E.; LOPES, A.S.; BATAGLIA, O.C. Análise química do solo para fins de fertilidade. Campinas: Fundação Cargill, 1987. 170p.

RAIJ, B. van \& BATAGLIA, O.C. Análise química do solo para micronutriente. In: SIMPÓSIO SOBRE MICRONUTRIENTES NA AGRICULTURA, Jaboticabal, 1988. Anais... Jaboticabal, 1988. p.537-62. (versão preliminar).

RAIJ, B. van. Fertilidade do solo e adubação. Piracicaba: Agronômica Ceres/ POTAFOS, 1991.343p.

RAIJ, B. van; BATAGLIA, O.C. Análise química do solo para micronutrientes: In: Simpósio sobre micronutrientes na agricultura. Anais. Jaboticabal, UNESP, 1988. v. 2, p. 537-69.

RAIJ, B. van; CANTARELlA, H.; QUAGGIO, J.A ; FURLANI, A.M.C. Recomendações de adubação e calagem para o Estado de São Paulo. Campinas: Instituto Agronômico \& Fundação IAC. 1996. 285p. 
REISENAUER, H.M.; WALSH, L.M.; HOEFT, R.G. Testing soils for sulphur, boron, molybdenum, and chlorine. In: WALSH, L.M. \& BEATON, J.D., ed. Soil testing and plant analysis. Madison: Soil Science Society of America, 1973. p. 173-200.

RIBEIRO, A.C.; TUCUNANGO SARABIA, W.A. Avaliação de extratores para zinco e boro disponíveis em latossolos do Triângulo Mineiro. Revista Brasileira de Ciência do Solo. v. 8, p. $85-89,1984$.

RITCHEY, K.D.; COX, F.R.; GALRÃO, E.Z.; YOST, R.S. Disponibilidade de zinco para as culturas do milho, sorgo e soja em latossolo vermelho-escuro argiloso. Pesquisa Agropecuária Brasileira, v.21, p.215-225, 1986.

RITCHEY, K.D.; COX, F.R.; YOST, R.S. Residual effects of zinc applications. In: Agronomic-economic research on tropical soils. Annual report for 1975. Raleigh, Soil Science Department, North Carolina State University, 1976, p.24-39.

RODRIGUES, T.E. Solos da Amazônia. IN: ALVAREZ, V.H.; FONTES, L.E.F.; FONTES, M.P.F. O solo nos grandes domínios morfoclimáticos do Brasil e o desenvolvimento sustendado. Viçosa: SBCS; UFV, DPS, 1996, p.19-60.

RODRIGUES, M.R.L. Resposta do dendezeiro (Elaeis guineensis Jacq.) à aplicação de fertilizantes nas condições do médio Amazonas. Piracicaba, 1993. 81p. (M.S.) - Escola Superior de Agricultura "Luiz de Qeuiroz"/USP.

RODRIGUES, M.R.L.; MALAVOLTA, E.; CHAILLARD, H.La fumure du palmier à huile en Amazonie centrale brésilienne. Plantations, researche, développement, v.4, p.392400, 1997.

SÁNCHEZ, P.A. Properties and management of soils in the tropics. New York, 
Wiley, 1976. 619p.

SÁNCHEZ, P.A.; BANDY, D.E.; VILLACHICA, J.H.; NICHOLAIDES, J.J. Amazon basin soils: management for constinuous crop production. Science, v.216, p.821-827, 1982.

SANTANA, C.J.L. de; IGUE, K. Formas de micronutrientes em solos da região cacaueira da Bahia. Turrialba, v.22, p.73-80, 1972.

SILLANPÄÄ, M. Micronutrients and nutrients status of soils: a global study. Roma, FAO, 1982. 444p. (FAO, Soils Bulletin, 48).

SILLANPÄÄ, M. Trace elements in soils and agriculture. Roma: FAO, 1972. 67p. (FAO, Soils Bulletin).

SILVA, J.M.L. da. Caracterização e classificação de solos do terceário do nordeste do Estado do Pará. Rio de Janeiro, 1989. 190p. (M.S.) - Universidade Federal Rural do Rio de Janeiro.

SILVA, A.R. da; ANDRADE, J.M.V. de. Correlações entre os teores de nutrientes nas folhas do arroz e rendimento em Latossolo vernelho-amarelo. Pesquisa Agropecuária Brasileira, v. 22, p. 153-162, 1987.

SILVA, A.R. da; ANDRADE, J.M.V. de. Efeito de micronutrientes no chochamento do trigo de sequeiro e nas culturas de soja e arroz, em Latossolo vermelho-amarelo. Pesquisa Agropecuária Brasileira, v. 18, p.593-601, 1983.

SIMS, J.T. \& JOHNSON, G.V. Micronutrient soil tests. In: MORTVEDT, J.J.; COX, F.R.; SHUMAN, L.M.; WELCH, R.M., ed. Micronutrients in Agriculture. $2^{\underline{a}}$ ed. Madison: Soil Science Society of America, 1991. p.427-476. 
SIMS, J.T. A comparison of Mehlich I and Melich III extractants of predictors of manganese, copper and zinc availability in four Delaware soils. Communications in Soil Science and Plant Analysis, v. 16, p. 1039-52, 1985.

SINGH, R. \& MOLLER, M.R.F. Disponibilidade de micronutrientes em classes dominantes de solos do trópico úmido brasileiro: I - Zinco. Belém, EMBRAPA CPATU, 1984. 43p. (Boletim de Pesquisa, 55).

SINGH, R. Disponibilidade de micronutrientes em classes dominantes de solos do trópico úmido brasileiro: II - Manganês. Belém, EMBRAPA - CPATU, 1984a. 42p. (Boletim de Pesquisa, 62).

SINGH, R. Micronutrient availability in dominant soil types of brazilian humid tropics. III Copper. In: Simpósio do Trópico Úmido, 1, Belém, PA, 1984. Resumos. Belém, EMBRAPA - CPATU, 1984b. p.47-48. (Documentos, 31).

SINGH, R. Micronutrient availability in dominant soil types of brazilian humid tropics. IV Iron. In: Simpósio do Trópico Úmido, 1, Belém, PA, 1984. Resumos. Belém, EMBRAPA - CPATU, 1984c. p.49-50. (Documentos, 31).

SIOLI, H. Tropical rivers as expressions of their terrestrial environments. In: GOLLEY, F. B. \& MEDINA, E., ed. Tropical ecological systems. Trends in terrestrial and aquatic research. New York: Springer-Verlag, 1975. p.275-288.

SOCIEDADE BRASILEIRA DE CIÊNCIA DE SOLO. Comissão Permanente de Métodos de Trabalho de Campo. Devisão de Pedologia e Fertilidade do Solo. Manual de métodos de trabalho de campo: $2^{2}$ aproximação. Rio de Janeiro, 1967. 33p.

SOLTANPOUR, P.N. Determination of nutrient availability and elemental toxicity by AB- 
DTPA soil test and ICPS. Advances in Soil Science. New York: Springer Verlag New York Inc. 1991. v. 16, p. 165-190.

SOLTANPOUR, P.N. Use of ammonium bicarbonate DTPA soil test to evaluate elemental availability and toxicity. Communications in Soil Science and Plant Analysis, v. 16, p.323-338, 1985.

SOLTANPOUR, P.N.; SCHWAB, A.P. A new soil test for simultaneous extraction of macro - and micro-nutrients in alkaline soils. Communications in Soil Science and Plant Analysis, v. 8, p. 195-207, 1977.

SOLTANPOUR, P.N.; WORKMAN, S.M.; SCHWAB, A.P. Use of inductively-coupled plasma spectrometry for the silmutaneous determination of macro and micronutrients in $\mathrm{NH}_{4} \mathrm{HCO}_{3}$-DTPA extracts of soils. Soil Science Society American Journal, v.43, p.75-78, 1979.

SOMBROEK, W.G. Amazon soils: a reconnaissance of the soils of the Brazilian Amazon region. Wageningen. Center for Agriculture Publications and Documentation, 1966. 292p.

TRAN, T. SEN; GIROUX, M.; GUILBEAUT, J.; AUDESS, P. Evaluation of Mehlich-III extractant to estimate the available P in Quebec Soils. Communications in Soil Science and Plant Analysis, v.21, p. 1-28, 1990.

VANDERLEI, J.C.; FAQUIN, V.; GUEDES, G.A. de A.G.; CURI, N. Boro em materiais de três solos do município de Lavras-MG. Pesquisa Agropecuária Brasileira, v.23, p. 1421-1429, 1988.

VETTORI, L. Métodos de análise de solo. Rio de Janeiro: Ministério da Agricultura, Equipe de Pedologia e Fertilidade do Solo, 1969. 24p. (Boletim Técnico, 7). 
VIÉGAS, I.J.M. Doses de NPK em viveiro de Hevea spp. na obtenção de plantas aptas para enxertia em latossolo amarelo textura média, na ilha do mosqueiro-PA. Piracicaba, 1985. 71p. Dissertação (M.S.) - Escola Superior de Agricultura "Luiz de Queiroz", Universidade de São Paulo.

VIEIRA, L.S \& SANTOS, P.C.T. Amazônia: seus solos e outros recursos naturais. São Paulo, Editora Agronômica Ceres Ltda, 1987. p.219-373.

VIEIRA, L.V. Manual da ciência do solo: com ênfase aos Solos Tropicais. São Paulo. Editora. Agronômica Ceres Ltda, 1988. 464p.

VIETS, F.G. \& LINDSAY, W.L. Testing soils for zinc, copper, manganese, and iron. In: WALSH, L.M. \& BEATON, J.D. Soil testing and plant analysis. Madison: Soil Science Society of America, 1973. p.153-72.

VITTI, G.C. Avaliação e interpretação do enxofre no solo e na planta. Jaboticabal, FUNEP, 1989. 37p. (Boletim técnico).

WALWORTH, J.L.; GAVLAK, R.G.; PANCIERA, M.T. Mehlich-3 extractants for determinatio of available $\mathrm{B}, \mathrm{Cu}, \mathrm{Fe}, \mathrm{Mn}$ and $\mathrm{Zn}$ in cryic Alaskan soil. Canadian Journal of Soil Science, v.72, p.517-26.

WENDT, J.W. Evaluation of the Mehlich 3 soil extractants for upland Malawi soils. Communications in Soil Science and Plant Analysis, v.26, p.687-702, 1994.

ZONTA, E.P.; MACHADO, A.A.; SIL VEIRA JUNIOR, P. Sistemas de análise estatistica para microcomputadores: manual de utilização. Pelotas, 1987. 145p. 